RICCARDO GIULIANO FIGUEIRA TORRE

\title{
A VALORIZAÇÃO DOS PRECEDENTES PELOS TRIBUNAIS SUPERIORES E A JURISPRUDÊNCIA DEFENSIVA.
}

\author{
Dissertação de Mestrado \\ Orientador: Professor Associado Doutor Ricardo de Barros Leonel
}

UNIVERSIDADE DE SÃO PAULO

FACULDADE DE DIREITO

São Paulo/SP

2015 
Riccardo Giuliano Figueira Torre

\section{A VALORIZAÇÃO DOS PRECEDENTES PELOS TRIBUNAIS SUPERIORES E A JURISPRUDÊNCIA DEFENSIVA.}

Dissertação apresentada à Banca Examinadora do Programa de Pós-Graduação em Direito, da Faculdade de Direito da Universidade de São Paulo, como requisito parcial para a obtenção do título de Mestre em Direito, na área de concentração Direito Processual, sob a orientação do Professor Associado Doutor Ricardo de Barros Leonel

UNIVERSIDADE DE SÃO PAULO

FACULDADE DE DIREITO

São Paulo/SP

2015 
Autorizo a reprodução e divulgação parcial deste trabalho, por qualquer meio convencional ou eletrônico, para fins de estudo e pesquisa, desde que citada a fonte.

Torre, Riccardo Giuliano Figueira.

A valorização dos precedentes pelos Tribunais Superiores e a jurisprudência defensiva. / Riccardo Giuliano Figueira Torre; orientador: Ricardo de Barros Leonel. - São Paulo, 2015. $191 \mathrm{f}$.

Dissertação (Mestrado) -- Universidade de São Paulo, 2015.

1. Precedentes. 2. Direito jurisprudencial. 3. Tribunais Superiores. 4. Jurisprudência defensiva. 5. Novo Código de Processo Civil. I. Leonel, Ricardo de Barros. II. Título. 
Nome: Torre, Riccardo Giuliano Figueira.

Título: A valorização dos precedentes pelos Tribunais Superiores e a jurisprudência defensiva.

Dissertação apresentada à Faculdade de Direito da Universidade de São Paulo, para concorrer ao Título de Mestre, pelo curso de Pós-Graduação em Direito Processual.

\section{Banca Examinadora}

Professor Associado Doutor Ricardo de Barros Leonel (Orientador)

Professor:

Julgamento:

Professor:

Julgamento:
Instituição:

Assinatura:

Instituição:

Assinatura: 
"Ever tried. Ever failed. No matter. Try again. Fail again. Fail better." (Samuel Beckett) 


\section{AGRADECIMENTOS}

À Velha e sempre Nova Academia, pela realização de um sonho, desde a graduação, e que me deu todos os alicerces necessários para ter chegado até aqui.

Ao meu orientador, Professor Ricardo de Barros Leonel, por quem nutro imensa admiração, tanto profissional como acadêmica, agradeço a confiança em mim depositada. Serei sempre grato pelos ensinamentos, pela paciência e pela amizade.

Aos Professores Cândido Rangel Dinamarco, José Roberto dos Santos Bedaque, Carlos Alberto Carmona, Antônio Carlos Marcato, José Rogério Cruz e Tucci, pelas infinitas contribuições ao estudo do processo civil que marcaram a etapa de cumprimento dos créditos que precederam esta dissertação, transformando-a em uma atividade extremamente valiosa e profícua. Aos Professores José Rogério e Marcelo José Magalhães Bonício, pelas essenciais sugestões dadas no exame de qualificação que procurei incorporar ao texto final do presente trabalho. Em especial aos Professores Marcelo Bonício e Sérgio Turra Sobrane, que muito me honraram pela participação na banca examinadora desta Dissertação.

A todos os amigos que me acompanharam nesta árdua caminhada, enriquecendo os debates e ajudando a resolver algumas das minhas (muitas) inquietações, agradeço especialmente nas pessoas do Alexandre Luiz Moraes do Rêgo Monteiro, Leonardo Cocchieri Leite Chaves, Gabriela Salomão Castelano, Maria Eugênia Previtalli Cais, Frederico Puppo Carrijo, Rodrigo Nacarato Stenico, Ciro Reginato Faria, Mariana Negri, Carolina Virgillito e Ana Cristina Bandeira.

Aos eternos companheiros de Arcadas, minha gratidão ao Pedro Henrique do Nascimento Oliveira, Leonardo de Aguiar Silveira, Rafael Carvalho de Fassio, Oswaldo Cesar Trunci de Oliveira, Pedro Saadeh de Albuquerque, Renata de Almeida Faria, Pier Angelli Maciel, Endrigo Cardim, Tasso Cipriano, Renata Vilella e Anna Carolina Venturini.

Aos colegas de Escritório, a quem agradeço na pessoa de seu fundador, meu querido Professor Arnoldo Wald, sobretudo pela figura humana ímpar que representa e pelos 
incontáveis exemplos de grandeza de caráter e humildade intelectual, sendo verdadeiro privilégio conviver consigo diariamente há quase seis anos, ao longo dos quais tenho buscado absorver, ao menos um pouco, de seu vasto conhecimento jurídico.

Não poderia deixar de agradecer, igualmente, aos meus antigos (e eternos) chefes Alexandre Nishioka e Suzana Melo, que muito me incentivaram desde o início desta empreitada e me deram valorosos conselhos que foram refletidos neste trabalho. Agradeço, ainda, aos meus atuais chefes André Correia e Letícia Abdalla, por permitirem e apoiarem a incessante busca pela conclusão desta etapa.

Agradeço, especialmente, à minha família, e o faço nas pessoas da minha mãe Denise, pelo amor e apoio irrestritos e incondicionais, desde sempre e para sempre me amparando e ajudando a perseguir meus objetivos, tendo me ensinado princípios e valores que carregarei comigo por toda a vida, e do meu avô Ivan, cujo exemplo de vida, retidão de caráter e avidez pelo conhecimento sempre me inspiraram.

Meu agradecimento individual à Juliana, sobretudo pelo amoroso companheirismo, paciência e compreensão durante esta longa jornada, ajudando a me dar o tão necessário equilíbrio para atravessar esse momento.

Por fim, a todos os demais amigos, amigas e familiares (próprios ou agregados), que, a despeito de não terem sido aqui citados nominalmente, fazem parte da minha vida e contribuíram para o resultado final. 


\section{RESUMO}

TORRE, Riccardo Giuliano Figueira. A valorização dos precedentes pelos Tribunais Superiores e a jurisprudência defensiva. $191 \mathrm{f}$. Dissertação (Mestrado) - Faculdade de Direito, Universidade de São Paulo, 2015.

O objetivo do presente trabalho consiste em examinar as medidas que têm sido adotadas no processo civil pátrio, desde a década 90, para mitigar o problema do excessivo volume de recursos que aguardam julgamento, há longa data, nos Tribunais Superiores, sendo a principal delas a valorização da utilização dos precedentes, de modo que o Capítulo 1 se ocupa de traçar esse panorama, apontando alguns fatores que contribuem para esse diagnóstico, a exemplo do déficit estrutural. A análise desse movimento sistêmico passa, necessariamente, pelo estudo da evolução histórica dos precedentes sob a perspectiva do direito comparado, a começar pelo direito português, além da análise da função por eles desempenhada em outras jurisdições de civil law e nos países de common law, em especial na Inglaterra e nos Estados Unidos (Capítulo 2). À luz dessas considerações, avaliar-se-á a função institucional que foi constitucionalmente atribuída ao Supremo Tribunal Federal e ao Superior Tribunal de Justiça, bem como os recursos de sobreposição a eles destinados, para, então, melhor compreender os principais mecanismos adotados, desde antes da Emenda Constitucional n. ${ }^{\circ} 45 / 04$, em prol da valorização jurisprudencial como uma das formas de acelerar os julgamentos e reduzir o contingente de processos, demonstrando-se a tendência brasileira de aproximação com a common law, temas esses que serão tratados no Capítulo 3. Outrossim, é imperioso estudar, ainda nesse contexto, a chamada “jurisprudência defensiva”, conceito formado no seio dos Tribunais Superiores que se utiliza de requisitos jurisprudenciais que restringem o acesso das partes às vias superiores, e que será abordado, no Capítulo 4, mediante o exame das diversas situações constatadas na práxis forense. No Capítulo 5, por derradeiro, abordar-se-á a última versão do Projeto do Novo Código de Processo Civil, que apenas aguarda sanção presidencial, corroborando o movimento de fortificação do direito jurisprudencial, com enfoque voltado essencialmente para todas as disposições que tratam tanto da utilização dos precedentes como da mitigação da sobredita jurisprudência defensiva.

Palavras-chave: Direito Jurisprudencial. Tribunais Superiores. Precedentes. Jurisprudência Defensiva. Projeto do Novo Código de Processo Civil. 


\begin{abstract}
TORRE, Riccardo Giuliano Figueira. The increasing importance granted to precedents from the Brazilian Superior Courts and the "defensive case law". $191 \mathrm{p}$. Thesis (Master of Laws) - Faculty of Law of the University of São Paulo, 2015.
\end{abstract}

The main scope of this thesis is to analyze the measures that have been adopted by Brazilian law, since the early 90's, to mitigate the problem of excessive amount of appeals that await final judgment, among which stands the increasing importance granted to precedents in Brazil. Subsequent to the introductory diagnosis exposed on Chapter 1, which points out the main causes for such scenario, including the lack of infrastructure, Chapter 2 deals with a historical study, from a foreign law perspective, which involves the study of precedents in Portuguese law, as well as in other civil law jurisdictions, in comparison to jurisdictions that are bound to the common law, namely England and the United States, where case law represents a role of paramount relevance. Moreover, such

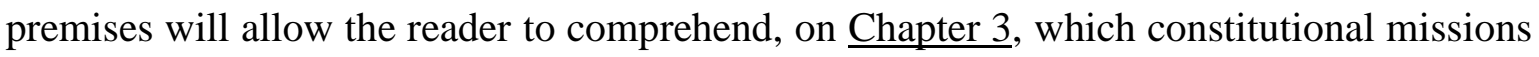
must be fulfilled by the Brazilian Superior Courts ("Supremo Tribunal Federal" and "Superior Tribunal de Justiça") along with the extraordinary appeals they have to judge. Third chapter will also bring an overview of the tools implemented in Brazilian law, even before Constitutional Amendment n. 45 entered into force in 2004, aiming to boost the importance of case law. Therefore, it will be demonstrated how Brazil, a typical civil law system, is getting closer to common law jurisdictions in certain aspects. However good such tendence is, a perverse aspect of case law in Brazil must also be pointed out, that is, the creation of requisites not legally foreseen in order to refrain parties from getting access to Superior Courts. Consequently, Chapter 4 analyzes some situations that consist of the so-called "defensive case law". Finally, the study on Chapter 5 encompasses the latest version of the Project for a New Brazilian Code of Civil Procedure, which only pends of presidential sanction, focusing not only on all relevant changes concerning the use of precedents but also demonstrating how the Project intends to eliminate the "defensive case law".

Keywords: Civil Procedure Law. Superior Courts. Precedents. "Defensive” case law. New Brazilian Code of Civil Procedure. 


\section{ZUSAMMENFASSUNG}

TORRE, Riccardo Giuliano Figueira. Die zunehmende Bedeutung von Präzedenzfällen Oberster Gerichtshöfen in Brasilien und die „defensiven“ Gerichtsverfahren. 191 S. Dissertation (Master) - Juristische Fakultät der Universität São Paulo, 2015.

Seit einigen Jahren müssen sich die brasilianischen Obersten Gerichtshöfen („Superior Tribunal de Justiça“ und „Supremo Tribunal Federal“, ähnlich jeweils zu den deutschen Bundesgerichtshof und Bundesverfassungsgericht) mit einem sehr schwierigen Problem beschäftigen: es gibt unzählbaren Berufungen, die beurteilt werden müssen. Jedoch verfügen die Gerichtshöfen nicht nur über unausreichende Zeit dafür, sondern auch über ungenügendes menschliche Infrastruktur. Um dieses chaotisches Panorama zu wenden, wurden seit 1990 einige Maßnahmen in das brasilianische Verfahrensrecht eingeführt, am Beispiel des Zurückgreifens auf Präzedenzfälle. Diese spielen eine sehr wichtige Rolle im brasilianischen Prozessrechtssystem. Die Verfassung vom Jahre 1988 ist 2004 geändert worden, um neuen Maßnahmen vorzustellen und diese Einführung wird im Kapitel 1 beschrieben. Um die Grundrisse der Benutzung von Präzedenzfällen in Brasilien verstehen zu können, wird zum einem das portugiesische Recht analysiert im Kapitel 2. Zum zweiten wird das englische Recht zusammen mit dem amerikanischen Recht untersucht. Beide gehören $\mathrm{zu}$ dem so genannten „Common Law“ und legen vielen Wert auf die Gerichtsverfahren. Aufgrund der zahlreichen Unterschiede zwischen dem „Common Law“ und dem „Civil Law“, ist das Erstere lernenswert. Auf dieses Thema wird im zweiten Kapitel eingegangen. Danach befasst sich das $\underline{\text { Kapitel } 3}$ mit dem brasilianischen Recht, nämlich mit Gesetzesänderungen, welche die Ähnlichkeiten des brasilianischen Rechts zum „Common Law“ beweisen. Obwohl diese Annäherung auf der einen Seite eine positive Tendenz darstellt, gibt es auf der anderen Seite auch negative Aspekte, am Beispiel der „defensiven“ Gerichtsverfahren. Diese werden im Kapitel 4 thematisiert. Hier geht es um formalen Bedingungen, die von den Gerichtshöfen - und nicht vom Gesetz stammen und darauf zielen, die Zulässigkeit von Berufungen von den Obersten Gerichtshöfen zu hindern. Letztens diskutiert $\underline{\text { Kapitel } 5}$ das neue brasilianische Zivilprozessgesetzbuch, das in kurzer Zeit von der brasilianischen Präsidentin zu erlassen ist.

Stichwörter: Zivilprozessrecht. Oberste Gerichtshöfen. Präzedenzfälle. „Defensiven“ Gerichtsverfahren. Neues brasilianische Zivilprozessgesetzbuch. 


\section{SUMÁRIO}

INTRODUÇÃO: A SOBRECARGA DOS TRIBUNAIS SUPERIORES BRASILEIROS.

1.1 O vácuo de eficiência do Poder Judiciário.

1.2 As principais tentativas de reforma sistêmica e a EC 45/04.

1.3 A guinada jurídica rumo à valorização dos precedentes e do direito jurisprudencial: caminho sem volta?.

1.4 Aparentemente sim: o novo CPC projetado.

1.5 Delimitação da estrutura da Dissertação. COMPARADO.

2.1 Abordagem histórico-evolutiva dos precedentes no direito hispanolusitano.

2.1.1 Direito peninsular pré-compilado......

2.1.2 A recepção do direito comum em Portugal........................................................ 37

2.13 Estilos e assentos da Casa da Suplicação portuguesa.......................................... 41

2.2 Direito moderno e contemporâneo...................................................................

2.2.1 Especificamente os precedentes e os Tribunais Superiores em alguns ordenamentos expoentes do civil law

2.2.1.1 França

2.2.1.2 Itália

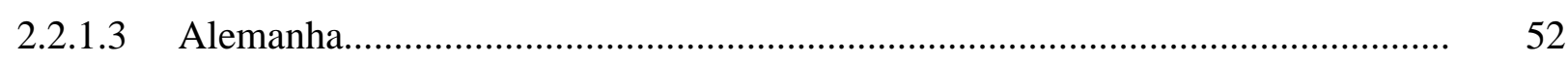

2.2.2 Os Tribunais Superiores no common law........................................................... 53

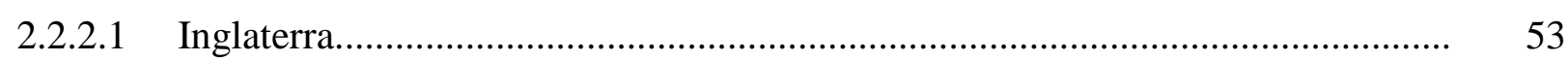

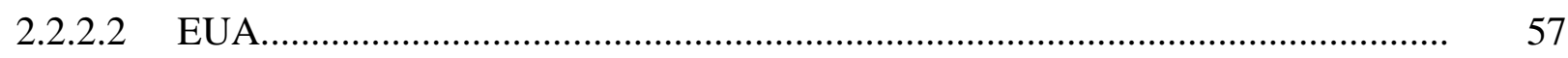

2.2.3 O precedente judicial como fonte do direito nos sistemas de common law e civil law: estabelecendo premissas em torno da uniformização jurisprudencial..

2.2.3.1 A interpretação dos precedentes na doutrina do stare decisis....... 
3.1 Breve evolução histórica: o STF e a criação do STJ.

3.2 Reflexões sobre a missão institucional-constitucional do STF e do STJ, os recursos de sobreposição e o problema da quantidade de recursos.

3.3 A evolução do precedente no direito brasileiro: rumo à common law?

3.4 Os mecanismos de valorização e uniformização da jurisprudência no atual direito brasileiro

3.4.1 Repercussão geral

3.4.1.1 Repercussão geral nos recursos especiais: a PEC 209/2012............................ 108

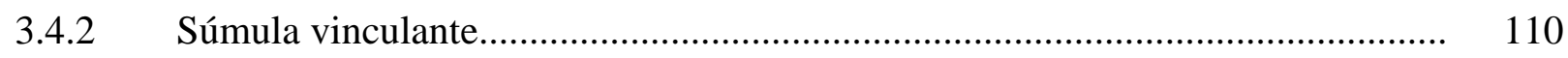

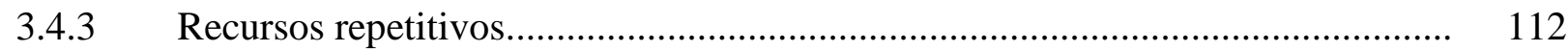

3.4.4 A Súmula impeditiva de recursos.................................................................. 113

3.4.5 Decisões proferidas em controle concentrado de constitucionalidade

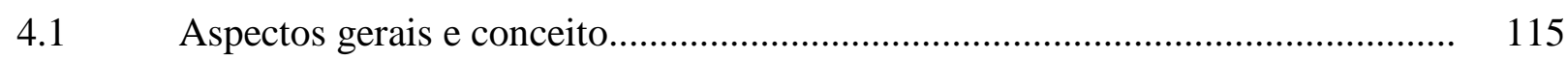

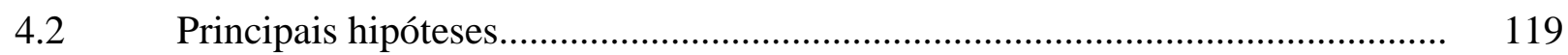

4.2.1 Súmulas 07 do STJ e 279 do STF: a vedação ao reexame de fatos e provas.

4.2.2 A Súmula 284 do STF e a questão da deficiência da fundamentação para demonstração da repercussão geral.

4.2.3 Exigência de preliminar formal demonstrando a repercussão geral do recurso extraordinário.

4.2.4 Irrecorribilidade da decisão que entende inexistir repercussão geral.

4.2.5 A questão específica do preparo: as guias de recolhimento.

4.2.6 A necessidade de ratificação de alguns recursos excepcionais.

4.2.6.1 Os recursos prematuros

4.2.6.2 Os recursos antecipados. 
5.1 A mens legislatoris: objetivos gerais

5.2 A explícita preocupação com a uniformização e estabilização da jurisprudência.

5.3 O tratamento diferenciado destinado ao precedente judicial.

5.4 O incidente de resolução de demandas repetitivas......

5.5 Principais inovações em relação aos recursos especial e extraordinário.

5.6 Fim da jurisprudência defensiva?

5.7 Considerações finais 


\section{INTRODUÇÃO: A SOBRECARGA DOS TRIBUNAIS SUPERIORES BRASILEIROS}

Desde o advento da República, em 1889, o Poder Judiciário pátrio assumiu, efetivamente, o caráter de poder político do Estado. Abandonou-se o sistema europeu continental e, em contrapartida, permitiu-se a influência do liberalismo norte-americano como vertente de ação e organização do Judiciário, ao qual cumpre não apenas a prestação do serviço de justiça social à população, mas também a administração da justiça, problemática que é tão cara aos dias atuais, tendo em vista que o bom desempenho desta função exige, a um só tempo, qualidade, eficiência e possibilidade de acesso a todos os jurisdicionados.

O problema decorrente da má administração da Justiça no Brasil não é recente, tampouco fácil de resolver, principalmente em meio a uma sociedade que, historicamente, é marcada por graves desequilíbrios sociais e que, a cada dia, torna-se mais complexa e tecnológica, de modo que tal questão ultrapassa os limites da ciência do Direito, chegando a atingir a Sociologia Jurídica e a própria ciência da Administração.

Além da complexidade, uma tônica das sociedades contemporâneas é a "crise de gigantismo" a que se refere ARRUDA AlVIM, ainda mais acentuada em um país com as dimensões do Brasil, no qual os milhões de jurisdicionados procuram a Justiça para a resolução dos seus conflitos, gerando uma "inflação" de demandas em meio a um contexto de crescente litigiosidade ${ }^{1}$.

Tal constatação é ecoada inclusive nos corredores do órgão de cúpula do Poder Judiciário brasileiro, o Supremo Tribunal Federal (“STF”), de modo que um de seus integrantes, o Ministro LUIS BARRoso, entende que, “com a redemocratização, ocorreu no país um expressivo aumento na demanda por justiça, o que significou uma expansão exponencial de litigiosidade e, consequentemente, um grande congestionamento nos juízos e tribunais, 2 .

\footnotetext{
${ }^{1}$ NETTO, José Manoel de Arruda Alvim. A alta função jurisdicional do Superior Tribunal de Justiça no âmbito do recurso especial e a relevância das questões. In: STJ 10 anos: obra comemorativa 1989-1999. Brasília: STJ, 1999, p. 42.

${ }^{2}$ Portal Migalhas. STF se aproxima da terceira década de existência sob severa crise de funcionalidade, diz Barroso, 26.08.2014. Disponível [online] em http://www.migalhas.com.br/Quentes/17,MI206523,71043-

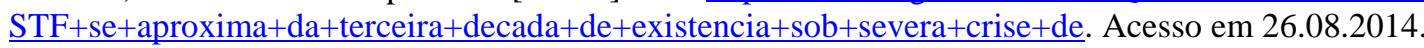


A temática em questão se insere em um contexto mais amplo. Com efeito, o movimento constituinte que culminou com a promulgação da Constituição Federal (“CF”) de 1988 carregou, insitamente, um sentimento democrático ao qual vieram atrelados novos direitos - sociais, coletivos e difusos - que, por conseguinte, propiciaram à população uma maior conscientização quanto ao exercício de seus direitos subjetivos. Todavia, isso criou um "anseio progressivo de busca ao Judiciário"3, mas o Estado não estava preparado, estruturalmente, para lidar com a demanda que se seguiu.

Sendo flagrante o descompasso entre o aparelho estatal e o número de jurisdicionados, as instituições foram obrigadas, gradativamente, a alterar suas funções para fazer frente a esse "gigantismo" social.

Um exemplo claro disso é inchaço do STF, que, desde sua criação, tem visto paulatinamente seu perfil ser modificado, a fórceps, pelos fatores conjunturais, para se tornar praticamente uma Corte exclusivamente recursal em detrimento da sua incontrastável vertente também constitucional, hoje relegada a poucos casos ${ }^{4}$.

O embrião dessa crise não é recente novo e tem raízes históricas, muito mais profundas, tanto assim que vem sendo alvo de estudo de juristas e demais operadores do Direito desde muito antes da promulgação da CF 1988, que decidiu criar o Superior Tribunal de Justiça (“STJ") justamente para desafogar o STF.

Por intermédio da criação de uma segunda Corte Superior, segregando a análise das violações ao direito constitucional daquelas que afrontem a legislação federal, o Brasil adotou uma medida bastante usual em alguns Estados de Direito modernos e contemporâneos, à semelhança principalmente da Itália e Alemanha.

Posteriormente, em virtuda da insuficiência da criação do STJ para resolver o problema do acúmulo de processos, a promulgação da Emenda Constitucional n. " 45/2004 ("EC 45/04"), que recebeu a alcunha de "reforma do Poder Judiciário", ocorreu em meio a uma

\footnotetext{
${ }^{3}$ NOBRE JÚNIOR, Edilson Pereira. O direito processual brasileiro e o efeito vinculante das decisões dos tribunais superiores. Revista de Processo n. ${ }^{\circ}$ 105, ano 27, jan.-mar./2002, p. 65.

${ }^{4}$ FALCÃO, Joaquim; CERDEIRA, Pablo de Camargo; ARGUELHES, Diego Werneck. I Relatório Supremo em Números - Múltiplo Supremo. Rio de Janeiro: FGV, 2011. Disponível [online] em www.supremoemnumeros.com.br. Acesso em 13.11.2013.
} 
crise de eficácia e eficiência deste Poder Republicano, que estava praticamente à beira de um colapso.

Seu advento acarretou, decerto, muitas mudanças para o sistema constitucional e legal pátrio, haja vista que alterou dispositivos referentes a nada menos do que 25 (vinte e cinco) artigos da CF de 1988, assim como lhe acrescentou os arts. 103-A, 103-B, 111-A e 130-A, os quais impactam, inexoravelmente, no processo civil como um todo.

Todavia, foi mantido o princípio da unidade da jurisdição, inclusive com maior amplitude, porquanto o texto constitucional agora afirma que não se excluirá da apreciação do Poder Judiciário qualquer "lesão ou ameaça a direito", e não apenas "lesão a direito individual", tal como constava do texto anterior.

Isso se coaduna com a necessidade de instituição de um Judiciário independente, que possua autonomia financeira e administrativa, como conditio sine qua nom para a efetividade da tutela jurisdicional. A garantia de independência da magistratura em face do poder político, aliás, já havia sido apontada como essencial à garantia da imparcialidade dos juízes por MaUro Cappelletti ${ }^{5}$.

A grande quantidade de dispositivos alterados e/ou inseridos mostra, desde logo, a vastidão e abrangência da reforma que alterou a Constituição. Dentre as principais inovações, imbricam-se questões afeitas (i) à própria função e aos recursos julgados pelas cortes superiores, (ii) a diversos princípios constitucionais; (iii) à unidade do direito e à uniformização da jurisprudência; e (iv) à introdução de práticas tradicionalmente adotadas por ordenamentos de common law, tal como as súmulas com efeito vinculante.

Referidas mudanças, a despeito de terem contribuído, de modo geral, para a melhoria da sistemática recursal, mostraram-se parcialmente insuficientes para a prática forense, passada uma década de sua introdução no nosso ordenamento jurídico.

Isso porque, ainda hoje, persiste, ainda que em menor medida, o que ARNoldo WaLd chamou, nos idos de 2006, de “caos Legislativo e Judiciário”, uma vez que a insegurança

\footnotetext{
${ }^{5}$ CAPPELLETTI, Mauro; GARTH, Bryant. Acesso à justiça, trad. de Ellen Gracie Northfleet. Porto Alegre: Sergio Fabris Editor, 1988, p. 12.
} 
jurídica vivida passa por vários fatores, a saber: (i) excesso de leis; (ii) falta de coerência do sistema; (iii) falta de racionalidade de alguns textos legais; (iv) lentidão do processo judicial; $(v)$ excessiva previsão legal de recursos ${ }^{6}$.

Até hoje, todos esses fatores permanecem vivamente presentes, resultando em uma insegurança jurídica atomizada e, ademais, no descrédito do Judiciário como poder.

Sociólogos e diversas instituições internacionais já houveram por bem verberar que o desenvolvimento de uma nação pressupõe a estabilidade de suas instituições democráticas e a segurança jurídica. Com efeito, RAYMOND ARON disse, certa feita, que se o quadro institucional possui um planejador com aspirações inovadoras, exige-se-lhe, em contrapartida, uma Administração e Justiça relativamente racionais e previsíveis ${ }^{7}$.

Nesse sentido, desde 1997 um relatório elaborado pelo Banco Mundial apontara a base jurídica como um dos ingredientes para o desenvolvimento sustentável ${ }^{8}$, cuja conclusão foi ecoada por um dos economistas-chefes do BNDES, Professor Armando PinheIro, que apregoava, em 1996, a imperiosa necessidade de reforma do Judiciário 9.

Essas constatações não se restringiram ao final da década de 90. Isso por que, mais recentemente, o Conselho Nacional de Justiça (“CNJ”), além de fundações privadas destinadas à pesquisa e desenvolvimento acadêmico, encabeçadas pela Fundação Getúlio Vargas ("FGV"), adotaram a iniciativa de esquadrinhar, e destrinchar, o raio x da sobrecarga do nosso Poder Judiciário, traduzindo em números o assoberbamento de trabalho da Corte Suprema, refletidos nos Relatórios "CNJ em Números” e "Supremo em Números", o qual já conta com três edições.

O cenário não poderia ser mais assustador e preocupante, afinal todas as pesquisas disponíveis, de suma relevância para os operadores do direito, concluem pela falência da

\footnotetext{
${ }^{6}$ WALD, Arnoldo. Eficiência Judiciária e Segurança Jurídica: A racionalização da legislação brasileira e reforma do Poder Judiciário. In: MACHADO, Fábio Cardoso \& MACHADO, Rafael Bicca (coords.). A Reforma do Poder Judiciário. São Paulo: Quartier Latin, 2006, pp. 52-54.

${ }^{7}$ ARON, Raymond. Les istitutions politiques de l'Occident dans le monde du XX siècle. In: Colloques de Berlin, La democratie a l'epreuve du XX siecle. Paris: Calmann-Levy, 1960.

${ }^{8}$ Banco Internacional de Reconstrução e Desenvolvimento - Banco Mundial. O Estado num mundo de transformação. Washington, Banco Mundial, 1997, p. 43. Disponível [online] em http://www.acervo.epsjv.fiocruz.br/beb/textocompleto/mfn11116.

${ }_{9}^{9}$ PINHEIRO, Armando Castelar. Judicial System Performance and Economic Development, BNDES, out./1996, p. 05.
} 
base jurídica brasileira em termos de progresso e desenvolvimento. E as razões para esse panorama caótico, em que pese serem objetivamente identificadas, apontam para a gravidade da situação.

Em primeiro lugar, porque mesmo após o advento da EC n. ${ }^{\circ}$ 45/04, não se efetivou o princípio da duração da razoável do processo, o que pode ser ilustrado pela constatação de que a duração média dos processos sob a relatoria de alguns dos ministros do STF aumentou $^{10}$.

Não se pode olvidar, pois, que o Direito, como sistema normativo instaurado em determinado tempo e lugar, deve se transformar de acordo com as necessidades da sociedade, com reflexo direto no Poder Judiciário, que deve ser dinâmico o suficiente para acompanhar as evoluções e mudanças de paradigma de toda ordem, como bem apontou Miguel ReALE ${ }^{11}$, razão pela qual a morosidade constitui um fator completamente antieconômico, inclusive do ponto de vista jurídico.

Além disso, observa-se, recorrentemente, que os dias atuais continuam marcados, paradoxalmente, por inúmeras leis despropositadas e, por outro lado, pela inexistência de regulamentação de temas cruciais em razão da inércia que acomete o Poder Legislativo brasileiro, existindo, contudo, quem enxergue com ressalvas o "ativismo judicial" que o STF tem apresentado em meio às suas missões institucionais ${ }^{12}$.

\footnotetext{
10 "É possível notar que a partir de 2004 não há um padrão de diminuição na duração média das liminares, muito embora tenha sido incluído na Constituição o direito fundamental à duração razoável do processo. Também fica claro que não há um padrão no tempo para julgar a liminar entre os ministros". (FALCÃO, Joaquim; HARTMANN, Ivar A.; CHAVES, Vitor P. III Relatório Supremo em Números: O Supremo e o tempo. FGV Direito Rio: Rio de Janeiro, 2014, pp. 12 e 17). Nesse sentido, é inconcebível aceitar a estatística segundo a qual um pedido de liminar demore - pasmem - cerca de 44 (quarenta e quatro) dias para ser analisado após ter dado entrada no STF, em que pese estar revestido de extrema urgência. Pior ainda quando se analisa o tempo decorrido até o trânsito em julgado das ações constitucionais, nunca inferior a 2,7 anos.

${ }^{11}$ REALE, Miguel. Teoria do Direito e do Estado. $3^{\text {a }}$ ed. São Paulo: Livraria Martins, 1940, p. 22.

${ }^{12}$ Invocando a tentativa de regulamentação das uniões homoafetivas via jurisprudência do STF, LENIO STRECK, ViCENTE BARRetTo e RAFAel OLIVEIRA apontam para a "tentativa de instauração de uma verdadeira jurisprudência da valoração, na medida em que se pretende criar uma 'abertura de espaços jurídicos' para a criação de algo que depende da regulamentação do Poder Legislativo." (STRECK, Lenio Luiz; BARRETTO, Vicente de Paulo; OLIVEIRA, Rafael Tomaz de. Ulisses e o Canto das Sereias: sobre ativismos judicias e os perigos da instauração de um terceiro turno da Constituinte. Revista Magister de Direito Civil e Processual Civil, ano VI, n. ${ }^{\circ} 31$, jul.-ago./2009, p. 07).
} 


\subsection{O vácuo de eficiência do Poder Judiciário}

Diante desse quadro, o Poder Judiciário tem desfrutado, perante a opinião pública, de imenso descrédito, sobretudo em virtude da sua reiterada ineficiência em atender rapidamente aos anseios de tutela jurisdicional justa, da inadequação dos julgados à realidade sócio-econômica, além de inúmeros escândalos, inclusive recentes, como os dos "super-salários" de alguns magistrados, que contribuíram para manter a população distante justamente do único Poder para o qual ela não contribui para a escolha dos membros.

O sentimento de "justiça" só se fez sentir, na acepção leiga do termo, por ocasião do julgamento da famigerada Ação Penal 470, por meio da qual diversos políticos foram julgados e condenados, pelo STF, inclusive à pena privativa de liberdade, julgamento este que foi aprovado pela grande maioria dos cidadãos.

Todavia, um vácuo de confiança persiste em torno do Judiciário, tanto é que PAULo DE TARSO RIBEIRO afirma, neste contexto, a existência de um enorme descompasso entre as estruturas do direito e as expectativas sociais, o que leva o sistema judicial a uma profunda crise, crise esta que supera até mesmo a cognição horizontal ou vertical dos conflitos, atingindo "os paradigmas do direito com reflexos na estrutura do sistema e conseqüencias por toda a sociedade, ${ }^{, 13}$.

Com efeito, o descrédito do Poder Judiciário brasileiro envolve, em grande medida, os problemas de dispersão da jurisprudência e falta de estabilidade. O diagnóstico e os remédios para essa crise funcional-institucional, que serão estudados nos capítulos subsequentes, estão, há alguns anos, na agenda do legislador, sem resolução definitiva até o momento.

Distanciamo-nos, pois, das três exigências básicas que são feitas do Judiciário, nas palavras do ex-Ministro do STF NELSON JOBIM: acessibilidade a todos, previsibilidade de decisões e decisões em tempo social e economicamente tolerável ${ }^{14}$.

\footnotetext{
${ }^{13}$ RIBEIRO, Paulo de Tarso Ramos. Direito e Processo: Razão Burocrática e Acesso à Justiça. São Paulo: Max Limonad, 2002, p. 116.

${ }^{14}$ Supremo Tribunal Federal. Discurso de posse do Ministro Nelson Jobim à Presidência do STF. 03.06.2004. Disponível [online] http://www.stf.jus.br/arquivo/cms/publicacaoPublicacaoInstitucionalPossePresidencial/anexo/Plaqueta_de_P osse_Ministro_Nelson_Jobim_na_Presidencia.pdf. Acesso em 13.10.2013.
} 
A demora para que seja proferida uma decisão final, aliada ao tempo e ao próprio sistema que permite a morosidade também na fase de execução, distanciam nosso Poder Judiciário da certeza e segurança jurídica que dele se espera ${ }^{15}$, gerando o que DonALDo ARMELIN chamou de dano marginal decorrente da duração do processo ${ }^{16}$.

Tais fatores, por conseguinte, além de não se coadunarem nem com o Estado de Direito, nem com o desenvolvimento nacional, acabam por deteriorar, ainda mais, o chamado "Risco Brasil", tão propalado por LuCiano CouTiNHo ${ }^{17}$. Efetivamente, temos uma legislação que comporta textos de épocas distintas, o que acaba por reunir momentos econômico-sociais também díspares, acarretando severas contradições, sem olvidar da falta de precisão quando da revogação da legislação pretérita, gerando incerteza para os jurisdicionados.

A corroborar o caos judiciário exposto por ARNOLdo WALd, o ex-ministro do STF Francisco REzEK ${ }^{18}$ aponta dois vícios graves no nosso direito: o primeiro é o fato de o processo civil ser regido por regras que parecem querer fazer com que ele não tenha fim; o segundo diz respeito ao direito material que, aprovado sem critério e sem o devido debate parlamentar, aumenta o grau de litigiosidade.

Em um Estado Democrático de Direito com o brasileiro, é imprescindível que se busque assegurar, a todos os cidadãos, a tutela jurisdicional, em cujo plano da efetividade se situa o acesso efetivo à jurisdição.

\footnotetext{
${ }^{15}$ Foi o que se observou, por exemplo, por ocasião do julgamento da tablita, cuja constitucionalidade foi discutida por quase vinte anos, desde as primeiras reformas monetárias de 1986, até ser finalmente decidida em 2005.

${ }^{16}$ ARMELIN, Donaldo. Uma visão da crise atual do Poder Judiciário. In: MACHADO, Fábio Cardoso \& MACHADO, Rafael Bicca (coords.). A Reforma do Poder Judiciário. São Paulo: Quartier Latin, 2006, p. 125.

${ }^{17}$ COUTINHO, Luciano. Risco Brasil, Risco do Brasil. Folha de S. Paulo de 10.10.1999.

18 "Há no Direito brasileiro dois vícios graves pedindo, já faz tempo, remédio urgente. Nossas regras de processo, antes de tudo, parecem não querer que o processo termine. Os recursos possíveis são muitos (creio não haver fora do Brasil trama recursiva tão grande e complicada), e pouca gente hoje crê que isso ajude mesmo a apurar melhor a verdade para melhor fazer justiça. (...) De outro lado, as regras de direito material que o legislador edita com fartura têm sido a matriz de processo em larga escala, sobretudo quando é o governo que legisla, sem o pressuposto do debate parlamentar. Numa equação simples, toda demanda é o resultado de duas pessoas haverem entendido coisas diferentes ao ler a mesma norma. A simplicidade e a clareza da lei previnem demandas. Mas pouco tem sido feito entre nós para isso, para evitar, com a qualidade da lei, que à sua edição sobrevenham processos em cascata." (REZEK, Francisco. $O$ direito que atormenta. Folha de S. Paulo de 15.11.1998).
} 
A despeito da introdução da garantia da razoável duração do processo no inciso LXXVIII do art. $5^{\circ}$ da $\mathrm{CF}^{19}$, por meio da citada EC 45/04, além da determinação para que a atividade jurisdicional seja ininterrupta (art. 93, XII), a morosidade da Justiça ainda é problema da maior grandeza, especialmente considerando-se que as Cortes Superiores pátrias - o STJ e o $\mathrm{STF}^{20}$ - continuam sem ter capacidade de julgar os milhares de processos que lhes são distribuídos anualmente.

Por oportuno, Alfredo BuZAID ${ }^{21}$, já nos meados de 1960, apontava para a crise do STF, demonstrando não ser temática jurídica recente, concluindo que a crise que assolava o tribunal era quantitativa, seguido por RodRIgo GARCIA DA FonSECA, que menciona a “crise de gestão" no seio do STF praticamente desde a sua criação ${ }^{22}$. Também nesse exato sentido, RUi BARBosa disse que"a Justiça atrasada não é Justiça, senão injustiça qualificada e manifesta" ${ }^{\text {,23. }}$.

A demora na prestação da tutela jurisdicional cria insegurança jurídica incompatível com o atual estágio de desenvolvimento do País, o que acaba, por vias oblíquas, atrasando a fixação de teses jurídicas que, se estabelecidas com maior presteza, evitariam o ajuizamento de inúmeras outras demandas idênticas, além de acentuar as desigualdades sociais, bem apontadas por José RogérIo CRUZ E TUCCI ${ }^{24-25}$.

\footnotetext{
19 José Augusto Delgado aponta que a duração razoável do processo decorre dos princípios do devido processo legal, direito de petição, acesso à jurisdição, eficiência e economicidade. Acrescenta, ainda, que o legislador, ao introduzir referido direito fundamental, o fez atrelando-o ao princípio da razoabilidade, porquanto liga a celeridade processual ao prazo dito "razoável". (DELGADO, José Augusto. Reforma do Poder Judiciário: Art. 5, LXXVIII, da CF. In: WAMBIER, Teresa Arruda Alvim; WAMBIER, Luiz Rodrigues et alii. (coords.). Reforma do Judiciário: Primeiras reflexões sobre a Emenda Constitucional n. ${ }^{\circ}$ 45/2004. São Paulo: Revista dos Tribunais, 2005, p. 358).

${ }^{20}$ Para fins metodológicos, considerar-se-ão, na presente Dissertação, o STJ e o STF como “Tribunais Superiores" ou "Cortes Superiores", muito embora o Tribunal Superior do Trabalho (TST) e o Superior Tribunal Militar (STM) também sejam considerados como tribunais superiores.

21 BUZAID, Alfredo. A crise do Supremo Tribunal Federal. Revista da Faculdade de Direito da Universidade de São Paulo, v. LV. São Paulo: 1960, pp. 327-372.

22 "Quase desde a sua criação, o STF vive uma crise na própria gestão dos casos que chegam para o seu pronunciamento. A superlotação dos escaninhos do STF é uma tônica de várias décadas." (FONSECA, Rodrigo Garcia da. O papel do Supremo Tribunal Federal e a repercussão geral no recurso extraordinário. In: MARTINS, Ives Gandra da Silva; JOBIM, Eduardo (coords.). O processo na Constituição. São Paulo: Quartier Latin, 2008, p. 205).

${ }^{23}$ BARBOSA, Rui. Oração aos moços, edição popular anotada por Adriano da Gama Kury. Rio de Janeiro: Fundação Casa de Rui Barbosa, 1997. Disponível [online] em http://www.casaruibarbosa.gov.br/dados/DOC/artigos/rui barbosa/FCRB_RuiBarbosa_Oracao_aos_mocos.p df. Acesso em 09.06.2013.

${ }^{24}$ TUCCI, José Rogério Cruz e. Garantia da prestação jurisdicional sem dilações indevidas como corolário do devido processo legal. Revista de Processo n. ${ }^{\circ}$ 66, São Paulo: RT, abr.-jun./1992, p. 72.

${ }^{25}$ Nesse diapasão, WALD é lapidar ao definir que "existe, pois, uma espécie de círculo vicioso em virtude do qual a incerteza em relação ao direito vigente e a procrastinação dos recursos congestionam os tribunais,
} 
Com efeito, o aprimoramento do sistema requer a racionalização do processo e a revisão e modernização legislativas, sem as quais não se atingirá a necessária segurança jurídica. A questão, portanto, é ciclotímica: a morosidade impera, e por causa dela foram pensados mecanismos diferentes.

\subsection{As principais tentativas de reforma sistêmica e a EC 45/04}

Desde o início da década de 90, alguns esforços foram empreendidos visando à consolidação da legislação vigente, à reformulação de textos obsoletos e à edição de novos diplomas legais, casos, v.g., do Código Civil de 2002, da reforma da Lei das Sociedades Anônimas, da Lei de Falências (Lei n. ${ }^{\circ}$ 11.101/05) e da criação das parcerias públicoprivadas, por meio da Lei n. ${ }^{\circ} 11.079 / 04$, dentre outros.

Todavia, a ampliação da via do acesso à justiça veio acompanhada da massificação dos conflitos e do crescimento dos casos múltiplos, identificáveis por veicularem uma mesma questão de direito, o que impôs a necessidade de o modelo processual civil ser repensado, à luz da nova realidade ${ }^{26}$.

Uma primeira tentativa de atingir esse desiderato foi a introdução e valorização do processo coletivo na década de 80 , o qual foi pensado, à época, como instrumental importante para a coletivização das questões de massa.

Entretanto, ele, isoladamente, não foi suficiente para resolver o problema por completo, sendo que alguns dos fatores comumente apontados para justificar a persistência dos entraves são os fatos de $(i)$ a decisão de improcedência não atingir os integrantes do grupo, classe ou categoria das pessoas abrangidas pelo objeto da ação coletiva e (ii) a pendência do processo coletivo não inviabilizar o ajuizamento de ações individuais pelos integrantes do grupo, classe ou categoria ${ }^{27}$.

tendo, outrossim, um efeito realimentador que multiplica os processos, tornando ainda mais precária a distribuição da Justiça." (WALD, A., op. cit., p. 55).

${ }^{26}$ MONNERAT, Fábio Victor da Fonte. O papel da jurisprudência e os incidentes de uniformização no Projeto do novo Código de Processo Civil. In: ROSSI, Fernando ET alii (coords). O futuro do processo civil no Brasil: uma análise crítica ao Projeto do Novo CPC. Belo Horizonte: Fórum, 2011, p. 185.

${ }^{27}$ MONNERAT, F. V. da F., op. cit., p. 186. 
Paralelamente a isso, várias "mini-reformas" foram empreendidas no Código de Processo Civil, nas duas últimas décadas, a fim de agilizar a dinâmica recursal, sendo que algumas das medidas implementadas giraram em torno do aumento dos poderes conferidos aos relatores dos recursos, permitindo-se o julgamento monocrático em determinadas hipóteses, listadas no art. 557, além da súmula impeditiva de recursos ${ }^{28}$. Outra novidade significativa que foi introduzida é a possibilidade de o magistrado de primeiro grau julgar liminarmente improcedente o pedido, nos moldes do art. 285-A do CPC.

A despeito de pouco (ou quase nada) relacionada à reforma estrutural do Judiciário, a EC 45/04 representou um inegável começo na tentativa de reformar, efetivamente, o sistema processual brasileiro.

Sem quaisquer dúvidas, por intermédio dela foram introduzidas mudanças de extrema relevância do ponto de vista técnico para os juristas, a exemplo da adoção de súmulas vinculantes, vinculando os órgãos componentes do Poder Judiciário e da Administração Pública como um todo (art. 103-A da CF), bem como a introdução da repercussão geral como outro requisito de admissibilidade dos recursos extraordinários (art. 102, $\S 3^{\circ}$, da $\mathrm{CF}$ ), medidas essas que, comprovadamente, reduziram consideravelmente o volume anual de recursos que chegam ao STF e aguardam julgamento ${ }^{29}$.

Ambas as medidas citadas se inserem em meio a outras em prol da valorização das decisões paradigmáticas dos tribunais, quais sejam, o recurso especial repetitivo (art. 543C do CPC), a súmula impeditiva de recursos (art. 518, $\$ 1^{\circ}$, do CPC); a possibilidade de decisão monocrática pelo relator (arts. 527, I, 544, \$4 e 557 do CPC); e o julgamento liminar de improcedência da ação inicial (art. 285-A do CPC).

Sem esvaziar parte do escopo do Capítulo 2 da presente dissertação, cumpre mencionar que a emenda promoveu alterações em matérias importantes que dizem respeito às Cortes Superiores.

No âmbito do STF, a ação declaratória de constitucionalidade passou a ser cabível contra lei ou ato normativo federal e estadual. Não obstante, a homologação de sentenças

\footnotetext{
${ }^{28}$ NETTO, J. M. de A. A., op. cit., p. 43.

${ }^{29}$ FALCÃO, J.; CERDEIRA, P. de C.; ARGUELHES, D. W., op. cit., p. 31.
} 
estrangeiras e concessão de "exequatur" às cartas rogatórias foram transferidas da competência do STF para o STJ.

A sistemática do recurso extraordinário também foi alterada, por meio do acréscimo de mais uma hipótese de cabimento (contra decisão que, em última ou única instância, julgar válida lei local contestada em face de lei federal), bem como por meio da inclusão de novo requisito extrínseco de admissibilidade, que é a demonstração de repercussão geral das questões constitucionais debatidas no caso.

A força vinculante das decisões de mérito proferidas pelo STF também foi ampliada, uma vez que o efeito vinculante passou a, explicitamente, ser aplicável tanto a decisões em sede de ações declaratórias de constitucionalidade, como de ações diretas de inconstitucionalidade, abrangendo a Administração Pública direta e indireta, em todos os níveis da federação, tal como explicitado acima. O rol das citadas ações constitucionais também foi alargado para incluir o Governador do Distrito Federal e a Mesa da Câmara Legislativa do DF.

No que atine ao STJ, as inovações da emenda atingiram principalmente o recurso especial, que passou a ser interponível contra decisão que julgar válida lei ou ato de governo local contestado em face de lei federal, deixando de lado a hipótese de lei local conflitante com lei federal.

Com relação às demais medidas, os antigos Tribunais de Alçada foram extintos e incorporados aos tribunais estaduais, assim como houve a criação do $\mathrm{CNJ}$, como forma de exercer o controle externo do Judiciário.

Isto posto, em que pese a alcunha dada à EC 45/04 ("reforma do Judiciário"), o panorama atual ainda exige diversas mudanças. O problema de excesso de processos para julgar está, em grande medida, atrelado ao baixo número de magistrados em comparação com a população absoluta de cada comarca/região. Isso corrobora a impossibilidade de que seja prestada a tutela jurisdicional adequada, porquanto a capacidade de julgar é inexoravelmente suplantada pela massa de processos. 
Nesse sentido, outra forma cogitada para mitigar estas disparidades foi a de reavivar antiga proposta de emenda constitucional (PEC 544/2002) prevendo a criação de quatro novos tribunais regionais federais $\left(6^{\mathrm{a}}, 7^{\mathrm{a}}, 8^{\mathrm{a}}\right.$ e $9^{\mathrm{a}}$ regiões), descentralizando principalmente o da $3^{\mathrm{a}}$ região, que abrange São Paulo, responsável, sozinho, por mais da metade dos processos de todo o Brasil.

A PEC, em que pese ter sido alvo de severas críticas, principalmente por parte do então Presidente do STF, Ministro JOAQUIM BARBOSA ${ }^{30}$, foi aprovada e convertida na Emenda Constitucional n. ${ }^{\text {7 }}$ 73/2013 ${ }^{31}$. A Emenda teve seus efeitos cautelarmente suspensos no bojo da Ação Declaratória de Inconstitucionalidade (“ADIn”) n. o 5.017, cujo mérito ainda pende de julgamento.

Ainda diante desse panorama, há outras medidas aventadas para melhorar a tramitação dos processos no País. Neste esteio, há doutrinadores que sustentam, por exemplo, a extensão da súmula vinculante às decisões proferidas pelo STJ, em especial àquelas relacionadas a matérias tributárias, administrativas e monetárias, caso do atual Ministro do STF LUIZ Fux $^{32}$.

Ademais, costuma-se citar a adoção do requisito extrínseco de admissibilidade da repercussão geral também para os recursos especiais, questão esta, aliás, que parece próxima de ser solucionada.

Por meio da Proposta de Emenda Constitucional ("PEC") n. ' 209/2012, o legislador pretende incluir os $\S \S 1^{\circ}$ a $7^{\circ}$ no art. 105 da $\mathrm{CF}$, sendo que tal emenda já foi aprovada pela Comissão de Constituição e Justiça da Câmara dos Deputados e pela Comissão Especial criada para a apreciação da matéria. Em maio de 2014, o Deputado Sandro Mabel

\footnotetext{
${ }^{30}$ Principalmente pelos custos que acarretarão ao Erário, estimados em cerca de $\mathrm{R} \$ 1$ bilhão, segundo pesquisa do IPEA. O valor representa um aumento de 59\% nos custos fixos da Justiça Federal de segunda instância, sem que a contrapartida (ganho de eficiência) seja garantida. Cf. Folha de S. Paulo, Caderno A6, 11.06.2013.

31 “Art. $1^{\circ}$ O art. 27 do Ato das Disposições Constitucionais Transitórias passa a vigorar acrescido do seguinte § 11: (...) § 11. São criados, ainda, os seguintes Tribunais Regionais Federais: o da $6^{a}$ Região, com sede em Curitiba, Estado do Paraná, e jurisdição nos Estados do Paraná, Santa Catarina e Mato Grosso do Sul; o da $7^{a}$ Região, com sede em Belo Horizonte, Estado de Minas Gerais, e jurisdição no Estado de Minas Gerais; o da $8^{a}$ Região, com sede em Salvador, Estado da Bahia, e jurisdição nos Estados da Bahia e Sergipe; e o da $9^{a}$ Região, com sede em Manaus, Estado do Amazonas, e jurisdição nos Estados do Amazonas, Acre, Rondônia e Roraima”.

${ }^{32}$ FUX, Luiz. A súmula vinculante e o Superior Tribunal de Justiça. Revista de Direito Bancário e do Mercado de Capitais, ano 8, n. 28, abr.-jun. 2005.
} 
apresentou substitutivo à PEC 209/2012 para incluir o art. 105-A na Carta Maior, a fim de regular a instituição da súmula impeditiva de recursos também no âmbito do STJ para desafogá-lo, o qual foi aprovado pelo Plenário da Câmara em 06.06.2014 ${ }^{33}$.

\subsection{A guinada jurídica rumo à valorização dos precedentes e do direito jurisprudencial: caminho sem volta?}

Todas essas questões, novidades e inquietações processuais não podem ser isoladamente consideradas.

Muito pelo contrário. Elas se inserem num contexto muito mais amplo - e extremamente relevante - da significativa constatação de que os problemas estruturais do nosso Poder Judiciário abriram caminho para que a EC 45/04 (e outras reformas legislativas esparsas) plantasse, no sistema jurídico brasileiro como um todo, o embrião de uma mudança aparentemente sem volta, qual seja, a busca pela uniformização e valorização da jurisprudência, através da valorização do mecanismo dos precedentes, que foi eleita como o "santo graal" pelo legislador e envolve a adoção, ainda que paulatina, de mecanismos típicos das famílias jurídicas de common law.

Este, certamente, será um dos temas-chave da presente Dissertação, analisando, criticamente, os bônus - e também os ônus - que tais escolhas carregam consigo.

Não à toa as últimas reformas que foram carreadas ao CPC atualmente em vigor já mostram, claramente, a tônica de ampliar o conceito de manutenção e verticalização dos precedentes judiciais, trasmudando algumas causas individuais em representativas de determinada controvérsia jurídica.

É o que se deu, por exemplo, por meio da ampliação da função dos magistrados de primeira instância e dos desembargadores quanto à aplicação dos precedentes judiciais (arts. 285-A e 518, $\S 1^{\circ}$, do CPC), além do aumento do caráter vinculante das decisões dos Ministros dos Tribunais Superiores quando da análise de recursos excepcionais (arts. 543A a 543-C).

${ }^{33}$ Câmara dos Deputados do Brasil. Proposta de Emenda Constitucional n. ${ }^{\circ}$ 209/2012. Disponível [online]em http://www.camara.gov.br/proposicoesWeb/prop_mostrarintegra?codteor $=1277724 \&$ filename $=$ TramitacaoPEC+209/2012. Acesso em 26.09.2014. 
Com efeito, a formação e valorização dos precedentes e da própria jurisprudência, sumulada ou não, que se busca uniformizar, podem autorizar, legitimamente, a aceleração do procedimento e a repetição da aplicação da tese consagrada no julgamento de todas as demandas individuais idênticas que tenham sido ajuizadas.

E é justamente esse - racionalização do processo e o julgamento das demandas individuais repetitivas - um dos principais escopos do Projeto de Novo Código de Processo Civil ("Projeto do Novo CPC"), como será visto adiante.

A um só tempo, a valorização dos precedentes é uma técnica que prestigia a igualdade entre os jurisdicionados, propiciando maior segurança jurídica e previsibilidade ${ }^{34}$.

Nessa seara, Teresa Wambier, uma das redatoras do anteprojeto do novo Código de Processo Civil que se avizinha, destaca três vantagens advindas do sistema de valorização dos precedentes, a saber:

(1) maior efetividade do processo, eis que, após a decisão de questão que vinha sendo reiteradamente debatida, reduz-se o gasto da atividade jurisdicional e das partes, permitindo tal economia também em casos futuros;

(2) maior respeito ao princípio da isonomia, na medida em que é dada a mesma resposta jurisdicional a casos de igual talante;

(3) maior previsibilidade e tranquilidade para o jurisdicionado, dentro do contexto da ampliação da segurança jurídica, pois se trata da demonstração de que o Poder Judiciário cumpre constitucionalmente uma de suas missões, que é justamente a de dar respostas que efetivamente interpretem e apliquem a lei, respostas essas que deverão ser respeitadas e seguidas no futuro ${ }^{35}$.

\footnotetext{
${ }^{34}$ Segundo MONNERAT, "valorizar os precedentes, e não apenas os vinculantes, é viabilizar um processo mais ágil, justo e équo, possibilitando, naqueles processos que discutem causas idênticas já pacificadas pelos tribunais, cortes procedimentais e a repetição do entendimento consagrado." (MONNERAT, F. V. da F., op. cit., p. 187).

${ }^{35}$ WAMBIER, Teresa Arruda Alvim. Recurso especial, recurso extraordinário e ação rescisória. $2^{\mathrm{a}}$ ed. São Paulo: Revista dos Tribunais, 2008, p. 210.
} 
Há, porém, um efeito perverso deste caminhar em direção aos institutos tradicionais da common law que a práxis forense tem revelado.

Com o passar dos anos, diante da permanência de problemas antigos e a criação de novas situações pela prática forense, as Cortes Superiores, ainda assoberbadas de recursos para julgar $^{36}$, vêm tentando criar jurisprudência no sentido de buscar, a todo custo, cercear o acesso às vias extraordinárias, não conhecendo de recursos por questões meramente formais, o que foi denominado de "jurisprudência defensiva".

Todavia, deve-se evitar que o processo civil, paulatinamente, seja transformado em instrumento adequado mais para se evitar uma decisão de mérito do que para dirimi-la. Caso contrário, não apenas a efetividade do processo se esvai, como o próprio prestígio da tutela jurisdicional, ocorrendo uma indesejável distorção na prestação jurisdicional com a conversão do instrumento único de sua efetivação no próprio objeto dela, fazendo-se mister “imunizar os juizes contra o processualismo, impedindo que o excesso de trabalho os convide a adotar uma postura defensiva, com a utilização do processo como um instrumento para esse distorcido fim". ${ }^{37}$

Esse fenômeno, inclusive, já fora destacado por José Carlos Barbosa Moreira, que verberou o seguinte: "o trabalho empreendido por espíritos agudíssimos levou a requintes de refinamento a técnica do direito processual e executou sobre fundações sólidas projetos arquitetônicos de impressionante majestade. Nem sempre conjurou, todavia, o risco a todo labor do gênero ao deixar-se aprisionar na teia das abstrações e perder o contato com a realidade cotidiana ${ }^{, 38}$.

Ao processo e suas normas, portanto, é preciso conferir sua exata dimensão, vinculada estritamente à sua instrumentalidade. A lentidão do processo judicial e o excesso de recursos persistem e persistirão ao menos até que o Projeto do CPC seja finalmente aprovado pelo Congresso Nacional.

\footnotetext{
${ }^{36}$ Em entrevista datada de 1998, o Ministro Carlos Velloso apontava um crescimento, à época, de 52\% no volume de processos com relacao ao ano anterior. Mais alarmante ainda são os dados que indicam o crescimento de $1856 \%$ no volume de processos em um período de 46 anos. In: Jornal da OAB, nov./1998, p.11.

${ }^{37}$ ARMELIN, Donaldo, op. cit., p. 129.

${ }^{38}$ Vide Exposição de Motivos do PL n. ${ }^{\circ} 3.253 / 04$, que deu origem à Lei n. ${ }^{\circ}$ 11.232/05.
} 
A problemática, portanto, está exposta: o sistema processual civil brasileiro ainda carece de maior efetividade, de modo a prestar a tutela jurisdicional em consonância com as diversas garantias que são constitucionalmente asseguradas aos cidadãos, isto é, em primeiro lugar garantindo-lhes, efetivamente, o acesso à Justiça, para, então, entregar-lhes a tutela - favorável ou desfavorável - em tempo razoável. Tudo isso, obviamente, sob o pálio da segurança jurídica.

E a principal medida eleita pelo legislador foi a fortificação do direito jurisprudencial, mesmo porque os Tribunais Superiores ocupam, no sistema jurídico positivo brasileiro, inegável posição de protagonismo, ainda que "improvável”, segundo o Ministro Luís Barroso, do STF, bem como é certo que elas "têm sido eficientes em conciliar a interpretação do sentimento social dominante com uma pauta de avanços sociais moderados”, o que todavia não impede a conclusão de que o STF está perto de completar 30 anos de existência democrática "sob severa crise de funcionalidade" 39.

A partir disso, dentro do próprio seio do Pretório Excelso está sendo erguida a bandeira de enfrentamento, com desassombro, do grande congestionamento dos juízos e tribunais. Recentemente, aliás, não se pode fechar os olhos para as iniciativas no seio do próprio STF de garantir maior segurança jurídica aos jurisdicionados, resolvendo questões embléticas que há muito pendiam de solução ${ }^{40}$.

De todo modo, em que pese o fato de a aludida EC 45/04 ter jogoado luz sobre muitos desses problemas, é interessante notar a inexorável tendência que vem dominando nosso ordenamento desde o advento de tais medidas reformadoras, qual seja, de caminhar em direção ao sistema do common law, visando à sua uniformização, inclusive com a adoção de técnicas por lá consagradas, como a súmula vinculante.

\footnotetext{
${ }^{39}$ Portal Migalhas, "STF se aproxima...", op. cit., p. 01.

${ }^{40}$ Uma delas, que certamente impacta o volume de processos (lato sensu) em trânsito, diz respeito ao posicionamento firmado pelo Supremo, no julgamento do Recurso Extraordinário n. ${ }^{\circ}$ 590.809, com repercussão geral reconhecida, por meio do qual prevaleceu o entendimento majoritário dos membros da Corte que entendem não ser cabível o ajuizamento de ação rescisória contra decisões com trânsito em julgado que tenham sido proferidas em harmonia com a jurisprudência do próprio STF, ainda que posteriormente ocorra a alteração do entendimento da Corte sobre a matéria. Com isso, a Corte prestigiou a segurança jurídica da coisa julgada. Cf. STF, Pleno, RE 590.809, Relator Ministro MARCo Aurélio Mello, j. em 22.10.2014.
} 
Com efeito, a aproximação do sistema brasileiro, notadamente de civil law, em relação aos instrumentos tradicionalmente utilizados em ordenamentos de common law, não é um movimento isolado; muito pelo contrário, trata-se de uma tendência inafastável, como forma de mitigar os entraves do acesso à Justiça brasileira, afinal "à ordem jurídica repugna o fenômeno de casos iguais serem decididos de maneira diferente”, mas a ela também não é permitida a estagnação que decorreria da uniformização perene ${ }^{41}$.

Não podem passar despercebidas, entretanto, as nuances e particularidades observadas no direito brasileiro, caracterizado por ter adotado um sistema misto de precedentes, no qual convivem pacificamente precedentes sem efeito persuasivo algum, precedentes com certo grau de persuasão e precedentes com efeito vinculante.

A dificuldade em se encontrar uma solução definitiva para a oscilação jurisprudencial no Brasil é ainda mais acentuada ao se ter em mente que os próprios Ministros do STJ e do STF, em diversas oportunidades, acabam por desrespeitar suas próprias decisões ${ }^{42}$, mas de uma maneira diferente, porxemplo, daquela consagrada no âmbito do overruling que é permitido e consagrado no direito norte-americano.

A valorização do direito jurisprudencial também deve ser analisada sob a ótica da coletivização do julgamento de recursos, principalmente por meio do julgamento de recursos repetitivos, cuja orientação aplicada no leading case selecionado é replicada para os demais.

De um lado, é certo que a aproximação com ordenamentos estrangeiros propicia um resultado mais célere, porquanto casos análogos vêem a aplicação de idêntica solução jurídica, e de outro, confere-se maior segurança e estabilidade jurídica, servindo a uma maior uniformização da jurisprudência.

\footnotetext{
${ }^{41}$ GRECO FILHO, Vicente. Direito Processual Civil brasileiro. $14^{\mathrm{a}}$ ed., São Paulo: Saraiva, 2000, p. 358.

${ }^{42}$ Segundo TERESA WAMBIER, "a jurisprudência dominante [por meio] da súmula do STJ ou do STF, como parâmetros para a decisão (...) só podem gerar resultados saudáveis se os Tribunais Superiores deixarem de alterar suas decisões. Caso contrário, ousaríamos dizer que a quase todas essas inovações poderão ser consideradas um desastre. (...) Admitirem-se decisões diferentes concomitantes ou, ainda, as tais 'grandes viradas', é negar o Estado de Direito, é estimular a propositura de ações e o ato de recorrer”. (WAMBIER, Teresa Arruda Alvim. A uniformidade e a estabilidade da jurisprudência e o Estado de direito: civil law e common law. Ideias e opiniões, v. 7. Curitiba, out./2009, p. 04).
} 
Nesse esteio, o próprio manejo das súmulas vem crescendo exponencialmente nas duas últimas décadas dentro do processualismo civil brasileiro, servindo para a orientação do respectivo tribunal onde são editadas sobre determinado tema, o que também representa enormes ganhos de eficiência.

Se é inegável que o direito jurisprudencial (por meio dos precedentes), como mecanismo de autotutela dos Tribunais Superiores diante do abusivo volume de feitos que aguardam julgamento, adquire cada vez maior relevo como fonte do direito em um ordenamento tradicionalmente centrado no direito legislado como o nosso, ele não pode, contudo, ser visto como a única panacéia para todos os óbices enfrentados pelos jurisdicionados, abrindo espaço para a já mencionada jurisprudência defensiva, por exemplo.

\subsection{Aparentemente sim: o novo CPC projetado}

A resposta à pergunta formulada no tópico precedente parece ser afirmativa: acredita-se que o ordenamento jurídico pátrio parece caminhar, sem olhar para trás, em direção à quase equiparação entre o direito jurisprudencial e a lei como fontes mais importantes do nosso direito.

Dada a atualidade do tema, que tem sido alvo de comentários pela maioria da doutrina processualista que se dedica ao seu estudo, e considerando que iminentemente será aprovado o Projeto do Novo CPC, é imperioso destacar que ele prevê muitas medidas especificamente em torno dos temas aqui tratados, e cuja análise permite concluir em qual extensão o panorama atual será alterado, assim como vislumbrar o prognóstico futuro.

A pertinência do exame acurado do que se projeta ser o novo Codex processualista civil brasileiro para o presente Trabalho é revelada desde a exposição de motivos, na qual um dos objetivos expressos do legislador é justamente o de exterminar - ou ao menos mitigar - a dita jurisprudência defensiva, ao mesmo tempo em que acentua, ainda mais, a valorização do papel da jurisprudência, das técnicas de coletivização dos julgamentos para casos idênticos e a preocupação com a uniformização da jurisprudência como veículo indutor de estabilidade do sistema. 
A fim de combater a jurisprudência defensiva, algumas das medidas aventadas dizem respeito (1) à possibilidade de regularização da representação processual junto aos Tribunais Superiores, como contraponto à Súmula 115 do STJ; (2) à previsão expressa de que o equívoco no preenchimento da guia de custas não resultará automaticamente na aplicação da pena de deserção, cabendo ao relator intimar a parte recorrente para sanar o vício ou pedir informações, em caso de dúvida, ao órgão arrecadador; e (3) à admissão de que a falta de peça obrigatória no agravo de instrumento não implicará a inadmissibilidade do recurso se o recorrente, intimado, vier a supri-la no prazo de cinco dias.

Claramente, o legislador mostra sua preocupação com o exagerado destaque que vinha sendo dado aos aspectos formais dos recursos, em detrimento do mérito. E é o julgamento do mérito que se procura prestigiar, ao extremo, no Projeto do Novo CPC, que fala, explicitamente, na extração do máximo rendimento de cada processo singularmente considerado.

Além disso, é dada ênfase à necessidade de se "criar uma disciplina jurídica minuciosa para a interpretação, aplicação e estabilização dos precedentes judiciais, estabelecendo regras que auxiliem na identificação, na interpretação e na superação de um precedente $^{, 43}$, ao lado da criação do incidente de resolução de demandas repetitivas.

A última versão disponível do Projeto do Novo CPC, na qual o estudo se baseará, foi aprovada pela Câmara dos Deputados ${ }^{44}$ em março de 2014 (Substitutivo ao PLS 166/2010) e retornou ao Senado Federal para apreciação, primeiramente por uma comissão temporária e depois pelo Plenário, a fim de aprovar as mudanças que sofreu naquela Casa e sanar os pontos de divergência ${ }^{45}$.

43 Câmara dos Deputados do Brasil. Item "f”, p. 04, Disponível [online] em http://www2.camara.leg.br/atividade-legislativa/comissoes/comissoes-temporarias/especiais/54alegislatura/8046-10-codigo-de-processo-civil/proposicao/pareceres-e-relatorios. Acesso em 01.02.2014. ${ }^{44} \mathrm{Na}$ Câmara, a tramitação foi autuada sob o n. ${ }^{\circ}$ PL 8.046/2010.

${ }^{45}$ Câmara dos Deputados do Brasil. Juristas tentam superar divergências entre versões do novo CPC. Disponível [online] em http://www2.camara.leg.br/camaranoticias/noticias/DIREITO-E-JUSTICA/470264JURISTAS-TENTAM-SUPERAR-DIVERGENCIAS-ENTRE-VERSOES-DO-NOVO-CPC.html. Acesso em 26.09.2014. 
Em 04.12.2014, a comissão temporária aprovou o relatório do Senador Vital do Rêgo, e em 17.12.2014 foi a vez do Plenário aprovar o texto-base do novo Código, que foi remetido à sanção presidencial ${ }^{46}$.

\subsection{Delimitação da estrutura da Dissertação}

Partindo do panorama desolador que assola o Judiciário brasileiro e é objeto deste Capítulo 1, é preciso voltar à gênese do problema, que passa pela própria origem das nossas instituições judiciárias, a fim de chegar à valorização dos precedentes, lato sensu, como tentativa de reverter esse quadro.

Assim, será feito, no Capítulo 2, um breve esforço de reconstrução histórica em torno da jurisprudência e de instrumentos análogos aos precedentes existentes na península hispanoibérica (v.g. façanhas) ainda no período medieval, sendo seguido pela evolução no âmbito português, com exemplificação por intermédio do instituto dos assentos.

Será necessário, outrossim, indicar, ainda no segundo capítulo, a importância e pontos fulcrais dos precedentes no sistema do common law, inseridos na doutrina inglesa do stare decisis, bem assim demonstrar-se-á a origem, criação e evolução das Cortes Supremas nos EUA e na Inglaterra.

A partir dessas premissas, será preciso estudar, brevemente, o funcionamento das cortes superiores nos principais adeptos do sistema da civil law na tradição romano-germânica, cujas características auxiliarão a compreensão do modelo eleito pelo constituinte brasileiro com relação aos Tribunais Superiores, detidamente analisado no capítulo 3.

Ainda no terceiro capítulo, será analisado (i) o surgimento do nosso Supremo Tribunal Federal, (ii) a reorganização do sistema judiciário pátrio a partir de 1988, permitindo-se traçar (iii) o raio-x da utilização do precedente no direito brasileiro, no contexto das demais medidas implementadas na EC 45/04 em prol da celeridade, coletivização dos julgamentos e valorização jurisprudencial como forma de atenuar a crise de eficiência do Judiciário apontada neste capítulo introdutório.

46 Portal Migalhas. Novo CPC vai à sanção presidencial. Disponível [online] em http://www.migalhas.com.br/Quentes/17,MI213017,11049-Novo+CPC+vai+a+sancao+presidencial. Acesso em 17.12.2014. 
Em que pese todas essas medidas saudáveis, chegar-se-á, por outro lado, à problemática da jurisprudência defensiva, temática que será conceituada e devidamente exemplificada no capítulo 4, tanto sob a ótica doutrinária como a partir de inúmeros julgados em que são identificadas práticas reiteradas de restringir o acesso aos Tribunais Superiores e impedir, portanto, que seu arquivo de processos pendente de julgamento seja aumentado.

Por derradeiro, também faz parte do escopo desta Dissertação avaliar as novas mudanças que serão trazidas para o processo civil brasileiro por meio do novo Código de Processo Civil, principalmente em relação à sistemática jurisprudencial e para os precedentes em si, inclusive quanto à jurisprudência defensiva, motivo pelo qual esta será a temática do capítulo 5.

A presente Dissertação, destarte, fará a interlocução entre história, presente e futuro, com vistas a propiciar àqueles que a leiam um entendimento aguçado, e crítico, em torno da opção legislativa, em cooperação com os Tribunais Superiores, pela valorização dos precedentes como tentativa de autodefesa em face dos até o momento insolúveis problemas de excesso de recursos que travam nossas Cortes e as afastam do seu perfil nomofilático constitucional. 


\section{OS PRECEDENTES E OS TRIBUNAIS SUPERIORES NO DIREITO COMPARADO}

Um dos inexoráveis efeitos da globalização e da complexidade das relações sociais é a dificuldade no exercício da jurisdição. Justamente por isso, a influência do direito estrangeiro passou a ser cada vez mais sentida no Brasil, principalmente à luz dos graves problemas na distribuição da justiça elencados no capítulo introdutório desta Dissertação.

Observa-se, claramente, que um dos principais objetivos das reformas que têm sido carreadas nos últimos anos é a valorização do sistema de precedentes, por meio da adoção da vinculação jurisprudencial.

O valor abstrato ínsito aos precedentes tanto nos sistemas do common law como na civil law guarda enorme semelhança: considerando que a função e o modus operandi do common lawyer e dos jurisconsultos não são muito distintos, nos países que seguem o common law é possível observar uma flexibilização da força dos julgados, ao passo que nos ordenamentos codificados há inegável tendência de os juízes, cada vez mais, a eles se aterem quando do momento decisório.

De modo a entender este inexorável movimento, sentido já há alguns anos, faz-se mister avaliar, antes mesmo da compreensão do precedente judicial como forma de expressão e verdadeira fonte do direito ${ }^{47}$, a evolução histórica da figura do precedente desde os primórdios da tradição jurídica, culminando no modelo adotado atualmente pelos principais ordenamentos, sempre à luz, é claro do papel desempenhado pelos tribunais.

Afinal, a investigação histórica permite uma análise do Direito como fenômeno social, próprio de uma cultura e, portanto, essencialmente mutável, tanto é que a História é, de certo modo, o laboratório teórico do Direito, na feliz expressão de MAURo CAPPElletti $^{48}$.

\footnotetext{
${ }^{47}$ Vide MONTORO, André Franco. Introdução à Ciência do Direito, 20ª ed. São Paulo: RT, 1991, p. 352.

48 CAPPELlETTI, Mauro. Dimensioni della giustizia nelle società contemporanee: studi di diritto giudiziario comparato. Bologna: Il Mulino, 1994, p. 24.
} 
Este embasamento teórico será imprescindível para compreender o "panorama histórico da cultura jurídica europeia”, expressão cunhada por ANTónio MANUEL HeSPANHA ${ }^{49}$, que se aplica, in casu, aos diferentes, mas análogos, contornos da figura do precedente nos sistemas de common law e civil law, de maneira a permitir o melhor entendimento da função dos tribunais superiores e da sistemática processual civil no Brasil.

\subsection{Abordagem histórico-evolutiva dos precedentes no direito hispano-lusitano}

\subsubsection{Direito peninsular pré-compilado}

Entre os séculos VIII e XI, praticamente não houve produção jurídico-literária na península ibérica, tanto é que tal período chegou a ser denominado de "siglos mudos", marcado pelo predomínio do costume sobre outras fontes do direito e pela fragmentação da unidade do direito romano motivada pelo Liber Judiciourum visigótico, fazendo com que se misturassem princípios e práticas senhoriais ${ }^{50}$.

Tais regras consuetudinárias, locais ou gerais, traduziam-se muitas vezes por meio de posturas ou estatutos, ou ainda por precedentes judiciais, chamados de façanhas. De acordo com NunES ESPINOSA GOMES DA SILVA, o julgamento por façanhas significava o julgamento a partir de exemplos, ou seja, em conformidade com a solução adotada para um caso paradigmático ${ }^{51}$.

As façanhas, pois, representavam sentenças proferidas em casos notáveis e duvidosos, cuja força vinculante decorria da autoridade concedida a quem as proferia e aprovava, servindo de aresto a ser imitado e seguido como lei quando voltassem a ocorrer ${ }^{52}$.

No âmbito do direito espanhol pré-compilado, a decisão judicial era também conhecida por facienda ou fazaña, originada de memória oral ou mediante anotações pessoais feitas pelos

\footnotetext{
${ }^{49}$ HESPANHA, António Manuel. Panorama histórico da cultura jurídica europeia. Lisboa: Publicações Europa-Amércia, 1997, p. 13.

50 TUCCI, José Rogério Cruz e; AZEVEDO, Luiz Carlos de. Lições de história do processo civil lusitano. São Paulo: RT, 2009, p. 159.

51 SILVA, Nunes Espinosa Gomes da. História do direito português: fontes de Direito, v. I. Lisboa: Fundação C. Gulbenkian, 1985, p. 115.

52 TUCCI, José Rogério Cruz e. Precedente judicial como fonte do direito. São Paulo: RT, 2004, p. 120.
} 
juízes que proferiam os julgamentos, daí decorrendo o significado de fato memorável, que valia como precedente ${ }^{53}$.

Nessa época, portanto, era comum a existência dos fueros, na Espanha, ou dos forais portugueses, que nada mais eram senão coleções de preceitos costumeiros e precedentes judiciais. Segundo TUCCI, eram "um documento escrito, outorgado pelo monarca, contendo regras jurídicas próprias de uma determinada comunidade, com âmbito de vigência restrito a um especificado território ",54.

Conforme avançava a Reconquista, o governo local ia restabelecendo seu poder, e para o exercício de suas mais variadas atribuições havia o auxílio da Cúria Régia, verdadeiro conselho para tratar conjuntamente dos assuntos de administração, legislação e justiça, tida como órgão jurisdicional mais importante do reino ${ }^{55}$. Suas sentenças serviam para a determinação de jurisprudência e tinham força vinculante para a decisão de casos similares, mas eram, em muitas ocasiões, meras confirmações formais da vigência de costumes $^{56}$.

\subsubsection{A recepção do direito comum em Portugal}

A uniformidade das instituições jurídicas europeias foi alvo de estudo por TOCQUEVILLE ${ }^{57}$, tanto é que deu azo ao surgimento do direito comum, com supedâneo no direito romano-canônico de Bolonha, cujo processo histórico foi denominado de "recepção" pela doutrina das fontes do direito.

Tratou-se, com efeito, de um acontecimento cultural que muito representou para a história das instituições jurídicas, porquanto, na visão de José Jesus CazeTTA JúnIOR, representou, em primeiro lugar, a vigência subsidiária do direito romano nos diversos

\footnotetext{
${ }^{53}$ TUCCI, J. R. C. e; AZEVEDO, L. C., op. cit., p. 160.

${ }^{54}$ TUCCI, J. R. C. e, Precedente...cit., p. 121.

${ }^{55}$ TUCCI, J. R. C. e; AZEVEDO, L. C., op. cit., pp. 160-161.

${ }^{56}$ CRUZ, Guilherme Braga da. O direito subsidiário na história do direito português. Separata da Revista portuguêsa de história: Coimbra, 1975, p. 181.

57 TOCQUEVILLE, Alexis de. O Antigo Regime e a Revolução. Trad. portuguesa de Laurinda Bom. Lisboa: Fragmentos, 1989.
} 
países europeus, por força, sobretudo, da prática judicial e do costume (usus receptum), e, em segundo, a aceitação de regras canônicas no direito secular ${ }^{58}$.

Por volta de 1200, houve a redescoberta do Corpus Iuris Civilis justinianeu, tradicional compilação e sistematização do direito romano realizada nos idos de 528 a 534 em Constantinopla, que, até o início do segundo milênio, não havia exercido grande influência na parte ocidental da Europa.

Inicialmente em Bolonha, expandindo-se a posteriori para Cambridge e Oxford, a compilação logo se tornou referência para a educação jurídica formal ${ }^{59}$, contribuindo para a formação de um novo grupo (juristas), já no século XIII, que passou a exercer funções de relevo junto à cúria e na jurisdição eclesiástica.

A recepção do direito comum, na península ibérica, não ocorreu uniformemente, haja vista a existência de suseranos apegados à tradição do costume, que a ela se opunham, além da resistência de natureza política, porquanto o direito romano proclamava a supremacia sobre todo o mundo cristão ${ }^{60}$.

Considerando (i) a influência do direito canônico desde o séc. XII e (ii) das fontes do direito comum no ensino universitário e na prática negocial e judiciária, renovando o pensamento jurídico, e a partir da incorporação do utrumque ius, foi adotado o princípio justinianeu de que as sentenças judiciais não tinham força normativa, motivo pelo qual a ordem jurídica passou a orbitar em torno do monarca, detentor do monopólio legislativo ${ }^{61}$.

Nesta senda, têm-se como expoentes maiores o Fuero Juzgo e o Fuero del Libro (tido como "monumento central do romanismo espanhol"62), inspirados nas fontes do direito comum, culminando na edição das Siete Partidas (com a contribuição do Mestre Jacob de las Leyes), a qual passou, em 1348, a ter força de lei.

\footnotetext{
58 JÚNIOR, José Jesus Cazetta. Os assentos da Casa da Suplicação. Revista do Advogado, ano XXV, n. 84, dez./2005, p. 75.

${ }^{59}$ Cf. VON MEHREN, Arthur Taylor; GODLEY, James Russell. The Civil Law System: an Introduction to the Comparative Study of Law, $2^{\text {nd }}$ edition. Boston: Little, Brown, 1977.

${ }^{60}$ TUCCI, J. R. C. e, Precedente...cit., p. 122.

${ }^{61}$ Idem, p. 123.

62 GIBERT, Rafael. El 'nuevo Savigny' en España. Estado de las investigaciones sobre derecho romano en la Hispania medieval. Colloquio internazionale su "cultura iberica e diritto romano", texto original, Sassari, 1980, apud TUCCI, J. R. C. e, Precedente...cit., p. 124.
} 
Por outro lado, apesar de as novas técnicas científicas terem demorado mais a chegar a Portugal, a legislação do reino passou, inegavelmente, a ser incrementada em decorrência do fortalecimento do poder real, à luz dos postulados justinianeus. Tinha-se, destarte, um ambiente propício à aceitação dos ius commune, aplicando-se-lhe às lacunas de um "direito consuetudinário cada vez mais ultrapassado e de uma legislação ainda em fase de formação”, como bem aponta TuCCI ${ }^{63}$.

Somente durante o reinado de D. Dinis é que o direito comum passou a gozar, definitivamente, de enorme prestígio, ante a tradução das Flores de las Leyes e Siete Partidas, além da fundação, pelo monarca, do Studium generale dionisiano, cujo fim precípuo era justamente o ensino do direito romano e canônico ${ }^{64}$.

Insurgiram-se, entretanto, vozes contra a prevalência, em solo português, de fontes castelhanas para fins de aplicação do direito subsidiário, de tal maneira que as leis régias promulgadas a partir de D. Afonso III (1248 em diante), juntamente com a atividade judicial, passaram a ser informadas pelas regras do Digesto, da Glosa de Acúrsio, do Decreto e das Decretais papais, denotando claramente a sobreposição da opinião dos doutores sobre as fontes hispânicas ${ }^{65}$.

Quanto à questão da interpretação das leis, o rei detinha o poder exclusivo de proceder à interpretação autêntica, tanto assim que, em caso de lacuna, o juiz devia submeter a causa justamente ao monarca, e se este realmente entendesse que não havia previsão na legislação disciplinando a matéria, ordenava que tal lacuna fosse suprida ${ }^{66}$.

De acordo com as Siete Partidas, consideradas como o mais importante código da Idade Média $^{67}$, estavam os juízes proibidos de recorrer aos precedentes judiciais, a ponto de serem considerados inválidos os julgamentos que neles se embasassem. De outro lado, em

\footnotetext{
${ }^{63}$ TUCCI, J. R. C. e, Precedente...cit., p. 125.

${ }^{64}$ Vide CRUZ, Guilherme Braga da. História do direito português (publicação devidamente autorizada das lições proferidas ao $1^{\circ}$ ano jurídico 55-56 pelo Exmo. Sr. Prof. Doutor Braga da Cruz; coligidas por A. Barbosa de Melo). Coimbra, 1955, pp. 190-191.

65 TUCCI, J. R. C. e, Precedente...cit., p. 126.

${ }^{66}$ Idem, p. 127.

67 Vide The Legislative Works of Alfonso X, el Sabio, Disponível [online] em http://faculty.washington.edu/petersen/alfonso/lawtrans.htm. Acesso em 15.11.2014.
} 
virtude da sua equiparação à lei, as sentenças do rei tinham efeito vinculante para casos futuros análogos ${ }^{68}$.

A situação da proibição do uso dos precedentes, porém, mudou em virtude do Alvará de 1518, que estabeleceu quatro regras básicas, consoante as lições de $\mathbf{T} \mathbf{U} \mathbf{C C I}{ }^{69}:$ (a) qualquer dúvida objetiva quanto à aplicação da lei devia ser levada diretamente ao regedor da Corte, o qual, então, remetia-na, à "mesa grande", a alguns desembargadores; $(b)$ persistindo a dúvida, o regedor submetia o caso ao rei, a quem cumpria dirimi-la; (c) a decisão que fosse proferida era inserida em um "livrinho" - posteriormente chamado de Livro dos Assentos ou Livro Verde, que serviria como um guia para evitar dúvidas futuras; e (d) tal decisão se tornava obrigatória, de modo que qualquer decisão contrária à diretriz real, por juiz, acarretaria sua supensão até que sobreviesse remição por graça real. Também a destacar a mudança de orientação, é válido invocar os escritos de MÁRIO JÚLIO DE ALMEIDA $\operatorname{Costa}^{70}$.

Os julgamentos efetivados a partir de então passaram a ser chamados de "assentos" e detinham, como será analisado com mais cautela adiante, valor normativo idêntico ao das próprias leis interpretadas, com eficácia vinculante para os casos futuros.

Percebeu-se, desde então, a preocupação do legislador com a uniformidade da jurisprudência, garantindo segurança jurídica e uniformidade na aplicação do direito.

Com a reforma pombalina, realizada durante o reinado de D. José, foram introduzidos os ideários iluministas no direito português, sendo que o principal expoente legislativo desse período foi a chamada Lei da Boa Razão, como forma de limitar a subserviência ao direito subsidiário, e, em contrapartida, fortalecer o direito nacional ${ }^{71}$.

\footnotetext{
${ }^{68}$ TUCCI, J. R. C. e, Precedente...cit., p. 128.

${ }^{69}$ Idem, p. 134.

${ }^{70} \mathrm{O}$ autor indicou que "o problema da interpretação da lei com sentido universalmente vinculativo para futuro foi disciplinado por um diploma da segunda década do século XVI”, qual seja, o Alvará de 10.12.1518, cujos dispositivos foram posteriormente incluídos nas Ordenações Manuelinas e, então, nas Filipinas. "Determinou-se que, surgindo dúvidas aos desembargadores da Casa da Suplicação sobre o entendimento de algum preceito, tais dúvidas deveriam ser levadas ao regedor do mesmo tribunal. Este convocaria os desembargadores que entendesse e, com eles, fixava a interpretação que se considerasse mais adequada. O regedor da Casa da Suplicação poderia, aliás, submeter a dúvida a resolução do monarca, se subsistissem dificuldades interpretativas”. (COSTA, Mário Júlio de Almeida. História do direito português. $3^{\mathrm{a}}$ ed. Coimbra: Almedina, 2000, pp. 300-301).

${ }^{71}$ TUCCI, J. R. C. e, Precedente...cit., p. 139.
} 
Através da aludida lei, foi vedada a remissão aos textos de Acúrsio e Bártolo, quando houvesse, no ordenamento pátrio, ordenações, leis ou precedentes do reino, assim como foram expressamente rejeitadas as leis romanas que não fossem fundadas na "boa razão". Esta expressão, aliás, veio definida na própria lei (diferentemente das Ordenações, que a mencionaram apenas incidentalmente) como representativa da recta ratio dos jusnaturalistas, padrão supremo de justiça e felicidade dos povos ${ }^{72}$.

Ademais disso, a Lei da Boa Razão teve outra importância histórica para fins da interpretação autêntica da lei e, por conseguinte, para a uniformização da jurisprudência, ao sistematizar a edição, pela Casa da Suplicação, dos estilos e assentos.

\subsubsection{Estilos e assentos da Casa da Suplicação portuguesa}

Os estilos da Corte vinham arrolados como fontes do direito tanto nas Ordenações Afonsinas como Manuelinas, e, a despeito dos embates acerca de sua distinção com relação ao costume, fato é que ambos não eram escritos, e possuíam eficácia a partir de seu reiterado uso.

TUCCI e AzEvedo assim definiram o instituto: "o estilo era a prática introduzida pelos juízes nos tribunais. E, por essa razão, por estilo se entendia a jurisprudência constante e uniforme dos tribunais superiores, ou seja, da Casa da Suplicação, em particular, e da Casa do Cível, mais tarde, das Relações". 73

Consoante a reiterada prática forense, foram sedimentados três requisitos para que determinada orientação pudesse ser considerada como estilo, a saber: (i) posicionamento não contrário à lei; (ii) antiguidade (10 anos ou mais); e (iii) confirmação por ao menos duas ou três decisões ${ }^{74}$.

Para entender a competência para sua edição, mister se faz proceder a um breve escorço histórico.

\footnotetext{
${ }^{72}$ CRUZ, G. B. da, O direito subsidiário...cit., p. 293.

${ }^{73}$ TUCCI, J. R. C. e, AZEVEDO, L. C. de, op. cit., p. 168.

${ }^{74}$ TUCCI, J. R. C. e, Precedente...cit., p. 137.
} 
Em 1582, Filipe I reformou os tribunais judiciais superiores, mantendo uma Relação no Norte (a Casa da Suplicação) e criando outra no Sul (a Casa do Cível) para o julgamento de apelações e agravos. Assim, a Casa da Suplicação constituía, ao lado da Casa do Cível, um desdobramento do tribunal da Corte para as matérias de justiça, cuja função era a de proceder à interpretação autêntica da lei e proferir assentos em caso de dúvida dos desembargadores ${ }^{75}$.

Basicamente, competia-lhes o julgamento, em última instância, dos pleitos judiciais, sendo que a Casa do Cível exercia tal competência nas comarcas e ouvidorias do Entre Douro e Minho, de Trás-os-Montes, da Beira e nas de Esgueira e Coimbra (da Estremadura); já a Casa da Suplicação (Tribunal Supremo), por sua vez, exercia jurisdição nas restantes comarcas do reino, nas ilhas, no Ultramar e, ainda, em alguns juízos privilegiados e especiais $^{76}$.

Por meio desses dois tribunais era exercido o controle - através do agravo ou da apelação sobre os órgãos da administração periférica da coroa, sobre os órgãos da administração local, ou, ainda, sobre a generalidade dos juízos particulares e privilegiados ${ }^{77}$.

Historicamente, a competência para a emissão de assentos em Portugal foi da Casa da Suplicação de 1518 a 1582, mas, com a reforma promovida por Filipe I, o Tribunal da Relação do Porto (Casa do Cível), a despeito da inexistência de autorização legislativa, passou a avocar competência para a sua edição, no que foi seguido pelas Relações criadas no Ultramar - Goa (1544), Bahia (1609) e Rio de Janeiro $(1751)^{78}$.

Todavia, a Lei da Boa Razão (1769) acabou com essa possibilidade ${ }^{79}$ : ressalvou que a competência para a edição de assentos com força de lei era exclusiva da Casa da Suplicação, posteriormente transformada no Supremo Tribunal de Justiça (1808), e declarou que os assentos editados pelas demais Relações apenas alcançariam valor normativo mediante confirmação da própria Casa da Suplicação, de forma a evitar o

\footnotetext{
${ }^{75}$ TUCCI, J. R. C. e; AZEVEDO, L. C., op. cit., p. 173.

76 JÚNIOR, J. J. C., op. cit., p. 83.

${ }^{77}$ HESPANHA, A. M., As vésperas...cit, p. 231.

78 TUCCI, J. R. C. e, Precedente...cit., p. 145.

79 Ao que TuCCI denominou de coibição da prática abusiva de editar assentos. Cf. TUCCI, J. R. C. e; AZEVEDO, L. C., op. cit., p. 173.
} 
proferimento de assentos contraditórios e, indiretamente, contribuir para a uniformidade do direito.

Quanto ao procedimento para proferimento dos assentos, os desembargadores das duas Relações tinham o privilégio de, reunidos na chamada "Mesa Grande", por convocação do regedor ou do governador, proferi-los sempre que existissem dúvidas sobre a interpretação das ordenações e das leis extravagantes. Os assentos, devidamente registrados no já aludido Livro Verde ou Livro dos Assentos, tinham valor vinculante para casos semelhantes que viessem a ocorrer futuramente e se subdividiam em assentos por efeito de dúvidas de interpretação levantadas pelos desembargadores e assentos por efeito de glosas do chanceler ${ }^{80}$.

O objetivo maior de sua emissão, como já apontado anteriormente, era o de resolver um conflito de jurisprudência, que podia ser a contradição $(i)$ entre dois acórdãos do STJ ou das Relações, quanto à mesma matéria de direito em torno da mesma legislação ou (ii) entre duas decisões de tribunais do trabalho ou da $3^{\text {a }}$ seção do Supremo Tribunal Administrativo $^{81}$, quando se tratasse de interpretação de igual norma especial de direito do trabalho, corporativo ou da previdência social, ou então acerca de preceito do código de processo do trabalho.

Em caso de dúvida ou alteração quanto a determinado usus fori, também se recorria ao tribunal pleno para a fixação, por meio de assento, do estilo antigo da Casa da Suplicação ${ }^{82}$, situação em que o assento também teria força vinculante.

Tratou-se, na visão de Castanheira Neves, de um "instituto jurídico original $e$ dificilmente compreensivvel", por meio do qual ocorria a conversão da doutrina ou de posição jurídica, pelo tribunal, e cuja prescrição normativa tinha força obrigatória geral.

Sua originalidade e importância residiram precisamente na possibilidade conferida a um órgão judicial de prescrever critérios jurídicos universalmente vinculantes, mediante o

${ }^{80}$ TUCCI, J. R. C. e, AZEVEDO, L. C., op. cit., pp. 167 e 173.

${ }^{81}$ A partir de 1963, quando foi promulgado o Decreto-lei n. ${ }^{\circ} 45.497$, tal competência foi estendida para o Supremo Tribunal Administrativo (STA), também em tribunal pleno, ainda que o regime de edição de assentos seja distinto entre eles. Ainda que de modo superficial, a principal diferença reside na possibilidade de derivarem do regime dos recursos, ou seja, no âmbito administrativo eles não podem ser suscitados em forma de recurso pela parte vencida.

${ }^{82}$ CRUZ, G. B. da, O direito subsidiário...cit., p. 285. 
enunciado de normas, que, como preceitos gerais e abstratos, desvinculavam-se da sua intenção e se destacavam dos casos ou decisões jurisdicionais que tenham estado na sua origem, com o propósito de estatuírem para o futuro ${ }^{83-84 .}$ Este viés interpretativo, influenciando a aplicação futura da lei objeto do assento, também foi destacado por José REINALDO DE LIMA LOPES ${ }^{85}$.

O instituto dos assentos, portanto, teve clara origem em figuras análogas do direito nacional português (por intermédio das façanhas e dos assentos das Relações) e de países europeus (arrêts de réglement do direito francês, como será demonstrado nos tópicos subsequentes).

Tal sistema vigeu em Portugal até 1993, momento em que o Tribunal Constitucional declarou a inconstitucionalidade do art. $2^{\circ}$ do Código Civil lusitano, na parte em que delegava aos tribunais competência para fixar doutrina com força obrigatória geral, por afronta ao art. 115 do texto constitucional ${ }^{86}$.

A diferença significativa para os demais institutos de direito comparado, entretanto, revelase tanto na sua natureza jurídica como em sua eficácia normativa.

Os assentos não representavam meramente a ratio decidendi de uma jurisprudência estabilizada, tal como se vê, por exemplo, nas origens da chamada "doctrina legal" do Supremo Tribunal espanhol, na qual é a orientação jurídica que se torna vinculante, ao passo que nos assentos se impõe, mediante uma norma expressamente formulada para o futuro, a solução de um conflito jurisprudencial, do que deflui que o assento é norma -

\footnotetext{
${ }^{83}$ NEVES, A. Castanheira. O instituto dos assentos e a função jurídica dos Supremos Tribunais. Coimbra: Coimbra Editora, 1983, pp. 02-04.

${ }^{84}$ Segundo MENEZES CORDEIRO, os assentos consistiam em proposições gerais e abstratas, cuja natureza era representativa de verdadeiras normas jurídicas em sentido material, tanto é que chegou a haver revogação de um assento por lei e, inclusive, a declaração de inconstitucionalidade de outro. [MENEZES CORDEIRO, António. Da inconstitucionalidade da revogação dos assentos. In: MIRANDA, Jorge (org.). Perspectivas constitucionais nos 20 anos da Constituição de 1976. Coimbra: Ed. Coimbra, 1996, pp. 800-808].

85 "'[Os assentos] fixavam a interpretação da lei, ou seja, a inteligência assim dada ao texto da lei é aquela que há de prevalecer em todos os casos de aplicação futura da mesma lei, diante de todos os outros tribunais e juizes do pais". (LOPES, José Reinaldo de Lima (org.). O Supremo Tribunal de Justiça do Império: 18281889. São Paulo: Saraiva, 2010, p. 125).

${ }^{86}$ Sobre a inconstitucionalidade dos assentos, vide NEVES, António Castanheira. O problema da constitucionalidade dos assentos. Coimbra: Almedina, 1994.
} 
constituída ex novo visando o futuro, e não jurisprudência, enxergada como consagração de soluções que vêm do passado ${ }^{87}$.

Tampouco pode o instituto ser identificado com o regime do precedente obrigatório, típico dos sistemas de common law e que será analisado mais adiante. Isso porque o precedente é uma concreta decisão jurisprudencial, vinculada como tal ao caso historicamente concreto que decidiu, ou seja, trata-se, estritamente, de decisão jurisdicional, a qual é imposta como padrão normativo casuístico em decisões análogas ou para casos de aplicação concretamente analógica. Destarte, não ultrapassa o plano do concreto casuístico com todas as decisivas consequiências, quer na intencionalidade jurídico-normativa, quer metodológica, que esse tipo de fundamentação e decisão implica ${ }^{88}$.

Independentemente das dúvidas suscitadas ao longo dos anos pela doutrina portuguesa ${ }^{89}$, é certo que o intuito da lei, no que se refere aos assentos, era justamente o de atingir a uniformização da jurisprudência, perseguindo a unitária estabilidade do direito, que satisfizesse a segurança jurídica e garantisse a certeza de uma unívoca aplicação ${ }^{90}$.

\subsection{Direito moderno e contemporâneo}

No século XVI, início da Europa moderna, a chamada Escola Culta tentou proceder à reestruturação dos textos jurídicos clássicos da antiguidade romana, com predomínio das fontes do direito nacional, motivo pelo qual tal período compreendeu o que HESPANHA chamou de "segunda recriação do direito romano, agora em moldes racionalistas". 91

Marcado por uma posição humanista, aquele contexto envolveu um processo de renovação amplo, abrangendo os setores ideológico, político e intelectual, culminando com o Renascimento, nos primórdios da Era Moderna.

\footnotetext{
${ }^{87}$ NEVES, A. C., op. cit., p. 11.

${ }^{88}$ LOPES, J. R. de L., op. cit., p. 12.

${ }^{89}$ NEVES, A. C., op. cit., pp. 20-21.

90 A modificação do paradigma, representada pela doutrina política da separação de poderes, secular e extremamente forte na argumentação jurídica, cuja versão clássica se manifestou, pela primeira vez, nos idos dos séculos XVII e XVIII, e teve sua máxima propagação no século XIX, fez com que o instituto não sobrevivesse a esse novo modelo de organização da estrutura estatal, concebido como a superação do absolutismo.

${ }^{91}$ HESPANHA, A. M. B., op. cit., p. 139.
} 
A atividade forense na Europa continental era então caracterizada por grande desorganização e insegurança, essencialmente em decorrência (i) do excesso de correntes doutrinárias e (ii) da morosidade processual. Não obstante, em razão da complicada organização interna dos tribunais, da qual derivavam juízos variados, havia enorme desconfiança em relação à própria noção de "justiça".

Desse modo, os juristas, já no início do séc. XVIII, resolveram se insurgir contra o despotismo desses tribunais, através de uma reforma judiciária em que apenas os legisladores teriam a tarefa de interpretação legal, uma vez que a pluralidade de jurisdições regionais acarretava várias exegeses distintas do direito comum, distanciando-se, portanto, da desejada e recomendável uniformidade, o que motivou a criação de tribunais centralizados, justamente para cumprir tal desiderato. Consoante os dizeres de TUCCI, " $a$ criação dessas cortes determinou o fim da dependência e submissão da justiça à ingerência política dos soberanos". 92

Por terem competência recursal, tais tribunais, com o transcorrer dos anos, passaram a se submeter aos precedentes por eles próprios editados, de modo a uniformizar a interpretação e aplicação do direito.

Desta feita, importante mencionar o grande destaque que a jurisprudência alcançou, principalmente no âmbito das Cortes europeias mais importantes, em substituição à até então predominante communis opinio doctorum, o que exige breve exame do papel desempenhado por tais tribunais e pelos precedentes que exararam, comparando-se os modelos do common law e civil law, a começar pelo último.

\subsubsection{Especificamente os precedentes e os Tribunais Superiores em alguns ordenamentos expoentes do civil law.}

A exemplo dos EUA e da Inglaterra, dominados pela regra do binding precedent (objeto do estudo que se seguirá), algumas experiências jurídicas contemporâneas do civil law contemplam, ainda que com intensidade diferente, o precedente judicial com força obrigatória, principalmente no controle de constitucionalidade das leis ${ }^{93}$.

\footnotetext{
${ }^{92}$ TUCCI, J. R. C. e, Precedente...cit., p. 192.

${ }^{93}$ Idem, p. 250.
} 
Roberta Calvano chega até a afirmar que a doutrina do stare decisis, antes tida como exclusividade inglesa, tem seus traços gerais espalhados por todo o continente europeu desde o século $\mathrm{XVI}^{94}$.

Nota-se, pois, uma "tendência de aproximação" entre as Cortes Superiores do common law e as Cortes Constitucionais do civil law ${ }^{95}$, jogando luz sobre o tema e mostrando ser relevante tecer algumas palavras sobre a estrutura e importância do precedente na França, Itália e Alemanha, também sob a mesma perspectiva histórica.

\subsubsection{França}

A França tem uma história peculiar, a começar pela dualidade de jurisdição, segregada entre Cortes judiciais e administrativas.

Por intermédio do référé législatif, criado em meio à Revolução Francesa, em 1790, foi reforçado o caráter que o julgador detinha, à época, de mero "bouche de la loi”, porquanto determinava que as questões jurídicas de duvidosa interpretação deveriam ser remetidas às Assembleias Legislativas.

Também em 1790, durante a Revolução Francesa, foi criado o Tribunal de Cassation, que posteriormente veio a se tornar a Cour de Cassation.

Inicialmente, a Cour de Cassation atuava como órgão político auxiliar do Legislativo, cuja função precípua era a de retificar as infrações cometidas pelas Cortes judiciais em face do texto de lei, isto é, “obstar que os juízes, proferindo sentenças en contravention expressse au texte de la loi, segundo o enunciado do Decreto de 27 de novembro de 1790, usurpassem as atribuições conferidas ao Poder Legislativo",96.

Àquele momento, portanto, sua função era meramente negativa, de anulação das sentenças de última instância, sem análise do mérito, devolvendo a causa a novo magistrado para julgamento. Caso esse novo julgamento fosse idêntico ao primeiro, poderia a parte, mais

94 CALVANO, Roberta. Lo stare decisis nella più recente giurisprudenza della corte costituzionale. Giurisprudenza costituzionale, n. 2, ano XLI, Milano: Cedam, mar.-abr./1996, p. 1280.

95 JÚNIOR, E. P. N., op. cit., p. 71.

${ }^{96}$ BUZAID, A., op. cit., p. 124. 
uma vez, socorrer-se da Cassação, mas se o novo julgamento fosse realizado em sentido contrário ao primeiro, haveria um decreto de interpretação da lei tendente a uniformizar a interpretação do terceiro juiz.

Somente em 1837 a Corte de Cassação assumiu a feição de órgão judicial, integrante do Poder Judiciário francês, com a possibilidade de rever qualquer sentença baseada em razões contrárias à sua orientação jurisprudencial. Todavia, há que se salientar que ela não se prestava a atuar como Corte de terceira instância, mas sim verificar se os tribunais inferiores aplicaram corretamente o direito à luz dos fatos, o que subsiste até os dias atuais, como bem define o próprio site do Tribunal ${ }^{97}$.

Assim, a Corte de Cassação francesa foi criada para assegurar a uniformidade das decisões, mas limitava-se (e limita-se) à análise tão somente das questões de direito, já julgadas em sede de recurso ordinário, com eficácia adstrita ao caso concreto.

Sua importância é destacada por TUCCI, ao apontar que "no limiar do século $X X$, a doutrina exaltava a influência que a Corte de Cassação francesa havia exercido na vida jurídica daquele país, especialmente no que se referia à elaboração e integração do direito material, que, por meio da interpretação jurisprudencial, logrou evoluir e adaptarse às mutações exigidas pela dinâmica social". ${ }^{9}$

Apesar disso, desde os primórdios havia a recomendação para que os juízes não se distanciassem muito dos precedentes já definidos pelas Cortes de Justiça, até porque a jurisprudência se prestava a salvaguardar a segurança jurídica e, bem assim, resolver a insuficiência de certos textos legais ultrapassados.

Nessa seara, uma das mais significativas atribuições da Corte é a de interpretar a lei preventivamente, mostrando a preocupação com a sua missão uniformizadora. Tanto assim

\footnotetext{
97 "Its purpose is essentially not to rule on the merits, but to state whether the law has been correctly applied on the basis of the facts already definitively assessed in the decisions referred to it. This is why the Court of Cassation does not, strictly speaking, rule on the disputes resulting in the decisions referred to it, but on those decisions themselves. In reality, it judges the decisions of other courts: its role is to state whether those courts have correctly applied the law in light of the facts, determined by them alone, of the case brought before them and of the questions put to them. The purpose of each appeal is thus to impugn a judicial decision, the task of the Court of Cassation being to state whether the law has been applied correctly, or indeed incorrectly". https://www.courdecassation.fr/IMG/File/About\%20the\%20court_mars09.pdf. Acesso em 03.11.2014.

${ }^{98}$ TUCCI, J. R. C. e, Precedente...cit., p. 224.
} 
que foi criado um procedimento consultivo, por meio do qual a Cour de Cassation analisa a lei ex ante, ou seja, previamente ao julgamento pelas Cortes de Apelação.

Assim, pode-se constatar que o sistema do precedente, na França, possuía e possui mais valor de fato do que de direito, mas, ainda que não haja previsão formal dentre as fontes de direito francesas, é cediço que os precedentes fixados exercem influência sobre as decisões futuras, a exemplo da figura dos arrêts de règlement, por meio dos quais o Parlamento determinava que a regra de direito derivada da decisão proferida acerca das causas de sua competência deveria ser seguida por todos os tribunais inferiores em casos análogos.

Por outro lado, o sistema francês não consagrou uma Corte Constitucional autônoma. Com efeito, Henry Abraham explica que nunca foi da tradição francesa permitir às suas Cortes a declaração de inconstitucionalidade das leis, ainda que em caráter limitado, tanto é verdade que isso só se tornou possível em 1958, com a proclamação da Constituição da $5^{\text {a }}$ República ${ }^{99}$.

A partir de então, foi criada uma figura singela, digna de nota, que é o Conseil Constitutionnel, composto por todos os ex-presidentes franceses e mais 9 (nove) outros membros designados pelo atual Presidente da República francês, pelo Presidente do Senado e pelo Presidente da Assembléia Nacional, cada qual com direito a 3 (três) nomeações $^{100}$.

Como o próprio nome diz, trata-se de um Conselho, que não integra o sistema judicial francês, mas tem o poder de declarar a inconstitucionalidade de todas as leis orgânicas e regras procedimentais das Casas que compõem o Parlamento francês, as quais, inclusive, devem ser submetidas previamente à aprovação pelo Conseil Constitutionnel ${ }^{101}$.

Em suma, tem-se que o sistema francês é único no mundo moderno. E a explicação para isso é a própria história do país, e da Revolução Francesa, que adaptou a instituição

\footnotetext{
${ }^{99}$ ABRAHAM, H. J., op. cit., p. 295.

${ }^{100}$ Para ver a atual composição, vide http://www.conseil-constitutionnel.fr/conseil-constitutionnel/francais/leconseil-constitutionnel/les-membres-du-conseil/liste-des-membres/liste-des-membres-du-conseilconstitutionnel-*.319.html. Acesso em 04.12.2014.

${ }^{101}$ ABRAHAM, Henry J. The judicial process: an introductory analysis of the Courts of the United States, England, and France. $2^{\text {nd }}$ ed. New York: Oxford University Press, 1968, p. 297.
} 
"justiça", outrora advinda apenas do Conselho do Rei, e a transferiu às Cortes, eis que estava perdendo sua "raison d'être"102.

Tamanha foi a importância e influência exercidos pelo modelo francês sobre outros ordenamentos que HeNRY Abraham chegou a destacar a aceitação e popularidade do sistema francês entre os Estados antigos e modernos, superior inclusive ao sistema anglosaxão ${ }^{103}$.

\subsubsection{Itália}

No que concerne aos países que adotaram o sistema francês de cassação, merece destaque a Itália, país em que a Corte Suprema de Cassação (Corte Suprema di Cassazione), órgão máxima na hierarquia do país, foi criado em 1941.

A Corte de Cassação, cuja competência envolve matérias cíveis e criminais, serve, em determinados casos, como autêntica terceira instância judiciária, posto que analisa novamente a causa à luz do direito e dos fatos que já tenham sido analisados em instâncias inferiores, conquanto apenas na medida do necessário para apreciar os fundamentos previstos por lei para a interposição do recurso perante esta instância. Paralelamente, também se presta a reconhecer determinados vícios expressamente previstos pela lei.

$\mathrm{Na}$ prática, portanto, ao reconhecer violações ao direito material (tanto errores in iudicando como in procedendo), vícios de motivação ou questões jurisdicionais, a Corte de Cassação não apenas anula a decisão recorrida, como efetivamente aplica o direito que julga adequado ${ }^{104}$.

102 "Yet the history of the Court goes back much further, being rooted in the way justice was practised under the Ancien Régime. Owing to the fact that, at that time, justice was a special preserve, stemming as it did from the King, the one possibility for an appeal to have a judgment of the Parlements overturned was for it to be considered by the King's Council. The essential contribution of the Revolution was to adapt this institution, just as it was losing its original raison d'être, transferring the power that belonged to the Head of State to courts. Through its development during the nineteenth century this institution acquired its now widely recognized authority". (Cour de Cassation française, The role of the Court of Cssation. Disponívrl [online] em https://www.courdecassation.fr/IMG/File/About\%20the\%20court_mars09.pdf. Acesso em 17.10.2014).

103 "If imitation may be regarded as an indication of approval, the popularity and acceptance of the French judicial system among the older as well as the newer states of the world represent such approval in the highest degree. Far more than the Anglo-American has the French administration of justice become a model abroad."(ABRAHAM, H. J, op. cit., pp. 257-258).

104 "The appeal in cassation may be lodged against the measures issued by the ordinary courts at the appellate level or in degree only: the reasons given to support the use may be, in civil matters, the violation 
Suas principais atribuições consistem em assegurar a correta aplicação da lei e a sua interpretação uniforme, assim como garantir a unicidade da lei objetiva nacional e o respeito aos limites entre as diferentes jurisdições, tal como consta da sua norma instituidora (art. 65 da Lei n. ${ }^{\circ}$ 12, de 1941).

Ao lado da Corte di Cassazione, a Itália também possui a Corte Costituzionale, criada sob a égide da Constituição de 1948, mas que começou a efetivamente funcionar apenas em 1956. É composta por 15 membros, escolhidos entre pessoas que tenham ao menos 20 anos de prática jurídica, sejam juízes experientes ou professores de Direito ${ }^{105}$.

A Corte Costituzionale dá a última palavra exegética sobre a Constituição, seja a respeito de leis nacionais ou regionais, que podem ser declaradas inconstitucionais, ex vi do art. 134 da Constituição italiana. O acesso a ela, porém, é difícil, mas pode ocorrer tanto por provocação das partes como ex officio pelos juízes; na primeira hipótese, porém, ela não ocorre diretamente, porquanto cabe aos próprios juízes filtrarem a relevância da arguição, funcionando como verdadeiros gatekeepers ${ }^{106}$.

Além da constitucionalidade das leis, cabe à Corte Constitucional julgar a inconstitucionalidade de atos do Poder Legislativo, cuja competência deve ser suscitada por juiz que se deparar com o julgamento do ato parlamentar.

Não estando subordinadas a nenhum outro órgão jurisdicional, cada qual em sua competência, a Corte di Cassazione e a Corte Costituzionale são responsáveis pela formação de uma jurisprudência iterativa, ou direito pretoriano, nas palavras de ROBERTA Calvano, em que pese o fato de suas decisões não terem caráter vinculante. Na prática,

of the right material (errores in iudicando) or procedural (errores in proceeding), the vices of motivation (lack, insufficiency or contradiction) of the judgment under appeal; or, again, the grounds for jurisdiction. A similar scheme is expected to appeal to the Supreme Court in criminal matters. If the Court finds one of the defects mentioned above, has the power and duty not only to quash the decision of the judge in the lower grade, but also to enunciate the principle of law that the contested measure must be observed: the principle that even the national court can not fail to comply when shall review the facts of the case. The principles laid down by the Supreme Court are not, however, binding on the courts, in general, when they must decide different causes, in respect of which the decision of the Supreme Court may, however, be considered a "previous" influential. In fact, the judges of the lower courts shall comply with decisions of the Supreme Court in the majority of cases". (http://www.cortedicassazione.it/corte-dicassazione/it/funzioni_della_corte.page;jsessionid=00E97829E80603D9F94717358AC6AC07.jvm1). Acesso em 04.11.2014.

${ }^{105}$ ABRAHAM, H. J., op. cit., p. 302.

106 Corte costituzionale italiana. The Italian Constitutional Court. Disponível [online] em http://www.cortecostituzionale.it/ActionPagina_324.do\#titolo5_1. Acesso em 01.10.2014. 
porém, a reiteração das teses acaba por adquirir caráter de precedente, sobretudo em razão da consciência que os juízes constitucionais tiveram, e têm, para transformar o conjunto das ratio decidendi neste direito pretoriano ${ }^{107}$.

A conclusão ora exposta é corroborada por Livio Paladin, ao mencionar as decisões declaratórias da Corte Constitucional que reconhecem a ilegitimidade de dispositivos legais com eficácia erga omnes, ou seja, acabam tendo um efeito constitutivo futuro, qual seja, impedir a aplicação posterior de determinada norma ${ }^{108}$.

\subsubsection{Alemanha}

Dentre os países que criaram tribunais e os dotaram, em maior ou menor escala, de poderes de revisão judicial, a Alemanha é apontada por HENRY ABRAHAM como "the most active and successful ${ }^{, 109}$.

No país, desde a Lei Fundamental de Bonn, de 1949, havia previsão expressa, por meio do art. 94.2 $2^{110}$, de conferir eficácia vinculante às decisões da Corte Constitucional (Bundesverfassungsgericht), que só foi criada em 1951 e é composta por 16 (dezesseis) magistrados, de ao menos 40 (quarenta) anos de idade cada, com destacada experiência jurídica, seja profissional ou acadêmica, sendo metade nomeada pela "Câmara" (Bundestag) e a outra metade pelo equivalente ao Senado brasileiro (Bundesrat).

Henry Abraham também houve por bem descrever suas funções, a saber: decidir todas as disputas envolvendo o alcance e eficácia da Lei Fundamental (Grundgesetz); a constitucionalidade de toda lei federal ou regional (dos Länder), ainda que tal caso não tenha sido apreciado pelas Cortes inferiores; e, finalmente, resolver controvérsias entre órgãos governamentais no âmbito nacional ${ }^{111}$.

Helmut Simon, a este respeito, consignou que "se subraya el peso del Bundesverfassungsgericht en la medida que lós órganos constitucionales de la Federación y de los Länder, así como todos los tribunales y autoridades están vinculados por sus

\footnotetext{
${ }^{107}$ CALVANO, R., op. cit., p. 1300.

${ }^{108}$ PALADIN, Livio. Diritto costituzionale. $3^{\mathrm{a}}$ ed. Padova: Cedam, 1998, p. 769.

${ }^{109}$ ABRAHAM, H. J., op. cit., p. 299.

${ }^{110}$ JÚNIOR, E. P. N., op. cit., p. 73.

111 ABRAHAM, H. J., op. cit., p. 300.
} 
decisiones, y en que las mismas tienen fuerza de ley en cuanto afecten a la constitucionalidad o inconstitucionalidad de normas. "112

Com a criação da Suprema Corte (Bundesgerichtsshof), órgão máximo em máterial cível e criminal, foi-lhe assegurada competência precípua para a interpretação e aplicação do direito federal no país, marcado, historicamente, pela inexistência de precedentes judiciais com efeito vinculante. Em que pese esse fato histórico, toda vez que o juiz discordasse da orientação predominante, era preciso submeter a questão à apreciação de um órgão superior dentro do próprio tribunal.

Dos poderes mencionados decorrem os dois mais significativos: "jurisdiction over disputes between the Federal Republic and the Länder regarding the latter's administration of the former's statutes, and guardianship over the fundamental rights and privileges of citizens as determined by the Basic Law both on procedural and substantive grounds" ${ }^{113}$.

É inegável, entretanto, que após a consolidação do império alemão, os precedentes das Cortes Superiores passaram a gozar, cada vez mais, de relevância no bojo das fontes de direito alemão, ainda que não tenha havido convergência quanto à sua posição como fonte formal de direito.

Passemos agora aos principais expoentes do sistema anglo-saxão.

\subsubsection{Os Tribunais Superiores no common law.}

\subsubsection{Inglaterra}

Como cediço e será melhor demonstrado adiante, o sistema do common law tem na jurisprudência sua fonte formal mais relevante, em detrimento da lei, que se limita a corrigir ou complementar a jurisprudência, e isso decorre das próprias circunstâncias históricas de desenvolvimento da ilha britânica e, consequentemente, da adoção de regime semelhante pelos EUA, sua antiga colônia.

112 SIMON, Helmut. La jurisdicción constitucional. In: BENDA, Ernesto et al. Manual de derecho constitucional. Madrid: Marcial Pons, 1996, p. 842.

${ }^{113}$ TUCCI, J. R. C. e, Precedente...cit., pp. 227-228. 
Historicamente, MARIA GarCIA aponta que, muito embora a receptividade do Direito Romano na Europa Ocidental tenha sido motivada pela necessidade política de unificação, calcada na substituição dos foros e costumes locais por um Direito de alcance universal (formado pelos glosadores sobre o Corpus Juris Civilis), fato é que tal receptividade não encontrou guarida na Inglaterra ${ }^{114}$.

E isso porque, nesse país, a função uniformizadora já havia sido exercida pelo Tribunal do Rei que, instaurado no início da dominação normanda, circulava por todo o reino e decidia os litígios de acordo com o common law, tido como fonte das particularidades jurídicas dos diversos territórios ${ }^{115}$. Após a conquista normanda em 1066, o common law foi solidificado $^{116}$.

A influência das universidades e da doutrina na Inglaterra foi sensivelmente menor, o que explicava, por muito tempo, a manutenção dos traços originários ao longo dos anos, panorama este que, hoje em dia, não mais se aplica totalmente, tendo em vista que os statutes (leis) não mais possuem função meramente secundária, desempenhando o statutory law, em verdade, papel semelhante àquele dos demais países do continente europeu.

A instauração de um poder centralizador, nas mãos do monarca, coadunava-se com o que seria implementado a seguir, isto é, a utilização do costume geral do reino sempre que o costume local fosse insuficiente para resolver algum litígio submetido aos tribunais reais.

Os tribunais reais de Westminster, destarte, foram responsáveis pela criação do common law, "un derecho de creación judicial mediante la aplicación de la doctrina del precedente $^{\text {"117 }}$. Ou, nas palavras de RENÉ DAVID, um direito jurisprudencial formalmente, mas substancialmente um direito costumeiro, consagrado e perpetuado pela jurisprudência $^{118}$.

\footnotetext{
114 GARCIA, Maria. Sistemas constitucionais comparados: o sistema inglês ("common law") e norteamericano. Alguns aspectos do direito constitucional brasileiro. Cadernos de Direito Constitucional e Ciência Política n. ${ }^{\circ}$ 09, ano 3, São Paulo: RT, out.-dez./1994, p. 53.

115 GARCIA, M., op. cit., p. 53.

116 JÚNIOR, E. P. N., op. cit., p. 67.

${ }^{117}$ GARCIA, M., op. cit., p. 54.

${ }^{118}$ DAVID, René. Traité Élémentaire de Droit Comparé, apud RÁO, Vicente. O direito e a vida dos direitos, São Paulo: Max Limonad, 1952, p. 74.
} 
Ao lado do direito comum, desenvolveu-se a prática da equity no Tribunal da Chancelaria, segundo a qual havia a súplica ao rei, por intermédio do chanceler, para que aquele interviesse de maneira a evitar o cometimento de injustiças, recorrentes em virtude do rigor com que os tribunais reais decidiam muitos dos casos.

Pois bem. Ambos os sistemas - common law e equity (enquanto esta vigorou) - eram baseados na doutrina do precedente, havendo compilações desde os tempos mais remotos, assim chamadas de Year Books. Mediante a consulta às decisões antigas, verificava-se se o caso era similar, ensejando a aplicação de idêntica solução, ou se era necessário adaptá-la às circunstâncias do caso concreto ${ }^{119}$.

Em um primeiro momento, os precedentes não tinham força obrigatória, sendo meramente persuasivos (persuasive precedents), sendo que o caráter vinculante só adveio no século XVII (binding precedents). Em 1898, o sistema da equity, cuja importância já havia sofrido grande abalo com o Judicature Act de 1873, foi definitivamente abolido do ordenamento inglês.

De modo a precisar a função dos tribunais superiores no país britânico, é preciso mencionar o Administration of Justice Act, de 1970, e o Courts Act, do ano seguinte, que disciplinaram a organização judiciária inglesa, tida, por muito tempo, como extremamente complexa.

A Supreme Court of Judicature constitui a assim chamada "alta justiça" do país, sendo formada pela High Court of Justice, a Crown Court (apenas para matérias penais) e a Court of Appeal. Esta, por sua vez, serve como uma segunda instância - revisora, portanto - das decisões proferidas pelas duas primeiras.

No ápice do sistema ficava, até 2009, a Câmara dos Lordes (House of Lords), que possuía um Comitê de Apelação, o qual, em situações excepcionais, podia julgar recursos interpostos contra decisões da Court of Appeal.

${ }^{119}$ JÚNIOR, E. P. N., op. cit., p. 67. 
Após 2009, portanto, houve uma significativa alteração no sistema judiciário britânico com a extinção da House of Lords e criação da Suprema Corte, ocupando a posição de mais alto tribunal recursal do Reino Unido.

A este respeito, NeIL ANDREws traça um breve panorama histórico, demonstrando que, durante o século XIX, à Corte competia julgar recursos extremos (equivalentes aos nossos recursos especiais e extraordinários), período em que foi acentuado o problema da morosidade, que culminou, ao final, com a extinção da Corte $^{120}$.

Alguns fatos históricos nesse interregno são dignos de nota. A partir de 1934, o acesso à House of Lords deixou de ser direito da parte, que passou a precisar de autorização, dada pelo juízo a quo ou pela própria House of Lords, razão pela qual é possível se afirmar que ela escolhe quais casos pretende julgar.

Em 1966, a Corte declarou seu poder de rever suas próprias decisões, possibilidade esta que foi utilizada vinte e uma vezes desde então. Em 2003, foi abolida a figura do Lord Chancellor e divulgado o intuito de inutilizar a House of Lords, transferindo sua competência para outra Corte, o que foi seguido por emenda constitucional, aprovada em 2005, delineando sua gradual extinção, que ocorreu definitivamente em 2009, como dito.

É preciso contextualizar o porquê dessa mudança no sistema inglês.

Como pontos positivos da existência da House of Lords são apontadas as valiosas contribuições doutrinárias e jurisprudenciais dadas pelos 110 (cento e dez) membros da Corte durante sua atuação, sedimentando princípios constitucionais fundamentais. Por outro lado, houve críticas quanto à atuação "distante" e "enraizada em outros tempos" do Tribunal.

Todavia, ANDREWS aponta como a principal razão para a mudança a necessidade de serem desmembradas as três funções primordiais do Lord Chancellor, que, na Constituição Britânica, reunia poderes típicos do Executivo, competência legislativa e judiciária, posto

\footnotetext{
${ }^{120}$ ANDREWS, Neil. A Suprema Corte do Reino Unido: reflexões sobre o papel da mais alta Corte britânica. Revista de Processo n. ${ }^{\circ}$ 186, ano 35, ago./2010, p. 301.
} 
que presidia o julgamento dos recursos interpostos perante a House of Lords e o Privy Council $^{121}$.

A criação da Suprema Corte, pois, "tornou realidade a separação dos poderes exercidos pelo Judiciário e a casa superior do Parlamento no Reino Unido "122, mas antes mesmo de sua criação, a House of Lords tinha competência recursal distinta da Court of Appeal, com ela convivendo harmonicamente: enquanto à House of Lords e à Suprema Corte competia o julgamento de recursos finais de causas cíveis provenientes da Inglaterra, Escócia e Irlanda do Norte, e causas criminais da Inglaterra, País de Gales e Irlando do Norte, à Court of Appeal, sediada em Londres, cumpria apenas julgar recursos interpostos em processos ingleses $^{123}$.

As decisões da Suprema Corte declaram qual o direito aplicável de forma vinculante para os demais órgãos do Judiciário inglês e galês, inclusive para todo o Reuno Unido em determinadas matérias.

Quanto à forma de julgamento, vale ressaltar que os juízes proferem seus votos por escrito e em separado, que são redigidos com base em pesquisas realizadas por seus assessores, resultando em acórdãos densos e com farta fundamentação, dificultando sobremaneira a identificação de qual foi a ratio decidendi utilizada.

Estas são, em linhas gerais, as Cortes Superiores que compõem o Judiciário inglês, sendo que, abaixo delas, há as assim chamadas jurisdições inferiores, separadas por matéria cível (Cortes de Condado) - ou criminal (Magistrate Courts).

\subsubsection{EUA}

Passemos agora aos EUA, que, justamente pela colonização inglesa, sofreram enorme influência do precedente vinculante oriundo do direito consuetudinário inglês, tanto assim que desde a colonização o sistema baseado no case law vigora em quase todo o território americano $^{124}$.

\footnotetext{
${ }^{121}$ ANDREWS, N., op. cit., pp. 304-305.

122 Idem, p. 306.

${ }^{123}$ Ibidem, p. 304.

${ }^{124}$ TUCCI, J. R. C. e, Precedente...cit., p. 165.
} 
Diferentemente da metrópole britânica, contudo, é consabido que os norte-americanos adotaram uma Constituição escrita desde $1787^{125}$, responsável por diferenciá-los da experiência jurídica britânica, e que foi tida como "the oldest, still-operative written, national constitution in the world" ${ }^{\prime 126}$, nela (i) positivando o princípio da separação dos poderes, em sua vertente clássica ${ }^{127}$ e (ii) atribuindo ao Congresso a importante tarefa de legislar constitucionalmente, o que fez com que aos juízes fosse apenas designada a missão de interpretar a lei, paralelamente à relevância das constituições estaduais ${ }^{128}$.

Tal feição, porém, não impediu a atribuição de efeitos vinculantes às decisões das Cortes superiores, federais ou estaduais, ainda que o sistema seja dual e que tenham que conviver uma Constituição nacional e cinquenta Constituições estaduais ${ }^{129}$.

O papel da Supreme Court desempenha a mesma função que, no Brasil, tem o direito positivo. Pela Constituição americana, porém, só foi fixada sua competência originária, sendo que a competência recursal foi deixada para o Congresso.

Em oposição à complexidade característica do sistema inglês, o americano não é de difícil compreensão.

Nenhum julgamento por tribunal de primeiro grau é vinculante. Já no âmbito das Cortes recursais, quer federais ou estaduais (que desfrutam de enorme influência em razão do federalismo constitucional norte-americano), o decisum configura precedente a ser seguido, respectivamente, pelas cortes distritais do correlato circuito ou pelas instituições que integram o Estado-membro ao qual a Corte pertence.

\footnotetext{
${ }^{125}$ A respeito de toda a formação e evolução histórica do sistema judiciário norte-americano, absolutamente permeada pela Suprema Corte do país, é válido conferir HUGHES, Charles Evans. Six Lectures on the Supreme Court of the United States. Columbia University Lectures: George Blumenthal Foundation, 1927.

${ }^{126}$ KATZ, Ellis. The complete American Constitution. Revista dos Tribunais n. ${ }^{\circ}$ 19, ano 5, abr.-jun./1997, p. 37.

${ }^{127}$ A despeito de vir positivada a supremacia da Constituição, tal princípio não responde à dúvida - existente até mesmo entre autores americanos - sobre qual texto deve prevalecer (Constituição nacional ou Constituição estadual) quando a violação, por ação de um estado-membro, atinge ambos os textos simultaneamente, o que demonstra que o sistema constitucional, justamente pelo número exíguo de artigos, deixa espaço para lacunas.

128 "The primary role of the states is to make policy choices dealing with that wide range of matters assigned to the by the very incompleteness of the U.S. Constitution.” (KATZ, E., op. cit., p. 39).

${ }^{129}$ ABRAHAM, H. J., op. cit., pp. 138.
} 
Quando chegamos à Suprema Corte ${ }^{130}$, principal figura em torno da qual se assenta a democracia americana, apontada como responsável por catalisar o progresso do País ${ }^{131}$ e quiçá por ser o tribunal mais poderoso do mundo ${ }^{132}$, todas as decisões possuem eficácia vinculante para os demais órgãos jurisdicionais, federais e estaduais, ou seja, eles são capazes de revogar os precedentes emanados dos circuitos no sistema federal, como bem aponta Charles ColE ${ }^{133}$.

Não obstante, com vistas a evitar o congelamento do sistema e do pensamento jurídico no âmbito da Suprema Corte, há o mecanismo do “overruling”, que, adaptado ao contexto brasileiro, seria uma figura análoga à ação rescisória, cabível para rever a coisa julgada ${ }^{134}$.

No primeiro século de existência, i.e., até 1891, a Suprema Corte americana não possuía o poder discricionário de escolher quais casos desejava julgar, atuando mais como um tribunal de revisão, posto que apreciava todos os litígios interestaduais até a criação dos tribunais regionais ("Circuits") ${ }^{135}$.

Prevalecia, então, o mandatory appeal, até que a Supreme Court, à qual eram submetidos poucos casos anualmente no início de sua vigência ${ }^{136}$, passou a se ver envolta em meio aos mesmos problemas brasileiros quanto à demasia de processos para julgar ${ }^{137}$, principalmente após a industrialização do país, motivo pelo qual o Evarts Act (também conhecido como Judiciary Act of 1891), além de ter criado as US Courts of Appeals,

${ }^{130}$ Cf. HARRELL, Mary Ann; ANDERSON, Burnett. Equal Justice under Law: The Supreme Court in American Life. The Supreme Court Historical Society: Washington, D.C., 1982.

${ }^{131}$ MACIEL, Adhemar Ferreira. Apanhado sobre a Constituição e a Suprema Corte dos Estados Unidos. Revista de Direito Público n. ${ }^{\circ}$ 73, ano XVIII, jan.-mar./1985, p. 165.

132 BARBOSA MOREIRA, José Carlos. O poder da Suprema Corte norte-americana e suas limitações. Revista Magister de Direito Civil e Processual Civil n. ${ }^{\circ}$ 23, ano IV, mar.-abr./2008, p. 12.

${ }^{133}$ COLE, Charles D. Precedente judicial: a experiência americana. Revista de Processo n. 92, ano 23, out.dez./1998.

${ }^{134}$ FERNANDES, Tarsila Ribeiro Marques. A influência da common law na teoria do precedente vinculante no ordenamento jurídico brasileiro. In: Publicações da Escola da AGU. ${ }^{\circ}$ Curso de Introdução ao Direito Americano: Fundamentals of US Law Course. Brasília: Escola da Advocacia-Geral da União, ano IV, n. 16, v. 2, abril/2012, p. 299.

${ }^{135}$ MACIEL, Adhemar Ferreira. Restrição à admissibilidade de recursos na Suprema Corte dos Estados Unidos e no Supremo Tribunal Federal do Brasil. In: FABRÍCIO, Adroaldo Furtado. Meios de impugnação ao julgamento civil: estudos em homenagem a José Carlos Barbosa Moreira. $2^{\mathrm{a}}$ ed. Rio de Janeiro: Forense, 2008, p. 08.

${ }^{136}$ Cf. STERN, Robert L. et. al. Supreme Court practice: for practice in the Supreme Court of the United States. $8^{\text {th }}$ ed. Washington: Bna Books, 1986.

${ }^{137}$ Segundo PaUlino JaCQUeS, "aconteceu com o Poder Judiciário o fenômeno semelhante ao que ocorreu com o Poder Executivo, principalmente nos Estados Unidos da América, onde o Judicial Power apresentou, durante mais de um século, acentuada hipertrofia”. (JACQUES, Paulino. Do relacionamento dos poderes políticos na Constituição do Império. Revista de Informação Legislativa n. ${ }^{\circ}$ 41, v. 11, Senado Federal, jan.mar./1974, p. 12). 
concedeu à Suprema Corte poder discricionário quanto ao conhecimento dos recursos, por meio do writ of certiorari ${ }^{138}$.

Ademais, disso, a Corte sofria críticas pela "unpredictability" dos seus julgamentos, relacionadas às questões políticas que envolviam o Chief Justice da época ${ }^{139}$.

Após a $1^{\text {a }}$ Guerra Mundial, voltou a aumentar o número das apelações, tornando a caseload americana "abarrotada, insurportável" 140 , de modo que a solução encontrada à época foi restringir as mandatory appeals, aumentando o número dos "petitions for writ of certiorari".

Depois disso, houve outra tentativa de redução do volume de processos por meio do "cert pool", mecanismo pensado em 1972 pelo Justice Lewis Powell, representando um filtro às petições de certiorari. Em que pese haver pouca informação a respeito, VALENTINA PINTO relata que o mecanismo consistiu na reunião de clerks de uma câmara para compartilhar certioraris com as outras seis câmaras, sendo um aspecto facilitador do trabalho dos Justices para o deferimento, ou não, do certiorari $^{141}$.

Nesse contexto, é certo que a má compreensão sistêmica do funcionamento das Cortes Superiores não é um privilégio brasileiro, tanto assim que STERN explica que cerca de $60 \%$ dos pedidos de certiorari são rejeitados, tendo em vista que a função da Suprema Corte não é a de rever erros ordinários, mas sim julgar questões de relevância nacional ${ }^{142}$.

\footnotetext{
${ }^{138}$ Expressão derivada do latim "certiorare", que significa "procurar".

${ }^{139}$ MACIEL, A. F., Apanhado...cit., p. 166. BRENNER e SPAETH, diante das reiteradas mudanças de posição da Suprema Corte (115 vezes em 44 anos), publicaram um estudo intitulado "Stare Indecisis", que bem retrata essa oscilação (BRENNER, Saul; SPAETH, Harold J. Stare Indecisis: the alteration of precedent on the Supreme Court. New York: Cambridge University Press, 1995).

${ }^{140}$ MACIEL, A. F., Restrição...cit., p. 08.

141 "In practical terms, the cert pool gathers clerks from one chamber to share the certiorari work with the remaining six chambers. The Chief Justice randomly assigns clerks with a copy of each petition received by the Court on a weekly basis. Clerks in the pool then divide the work, whereupon the clerks draft and circulate memos for all partipating Justices. Finally, each Justice receives the mark-up memos, along with the petition and briefs submitted by the parties. Usually, Justices only read the memos, analyzing briefs and petitions only when a grant of cert has been recommended or in more complicated cases. It is important to note that the final word on granting or denying cert is rendered by the Justices themselves, not the clerks. The cert pool is only one aspect of the analysis in the writ of certiorari”. (PINTO, Valentina Mello Ferreira. A comparison between the writ of certiorari in the United States and extraordinary appeal's general repercussion requisite in Brazil. Revista de Processo n. ${ }^{\circ}$ 187, São Paulo: RT, set./2010, pp. 130-131).

${ }^{142}$ STERN, R. L., op. cit., pp. 40-41 e 64.
} 
Por fim, em 1988 o Congresso americano retirou grande parte da competência da Suprema Corte, quase que eliminando por completo os mandatory appeals, sendo que todas as demais matérias passaram, desde então, a serem submetidos por meio do certiorari $^{143}$.

Mesmo assim, mais de 7.000 recursos de certiorari chegam, anualmente, à Suprema Corte, a maioria dos quais relativos a matérias criminais, como explica o juiz federal PETER MESSITTE $^{144}$, mas poucos deles são conhecidos ("granted"). O volume assusta, principalmente ao se considerar que apenas 9 (nove) Justices compõem a Suprema Corte americana, após as sucessivas mudanças, sendo um deles o presidente (Chief) e os demais juízes-membros.

Hoje, considera-se que a Suprema Corte americana exerce um papel eminentemente político e social, controlando as políticas públicas e pautando as liberdades civis, como explica LAWREnCE BAUM ${ }^{145}$, sendo considerado verdadeiro Poder, em que pese a subsistência de críticas ao excessivo poder conferido aos clerks $^{146}$.

Com o passar dos anos, destarte, percebeu-se a mudança substancial no perfil da Supreme Court, que deixou de ser uma Corte eminentemente recursal, para se tornar a guardiã da Constituição americana e de seus postulados, e foi a partir desse novo perfil que ela passou a selecionar quais matérias julgar, justamente para atingir esse desiderato maior.

Nessas breves considerações sobre o tema, não podemos deixar de destacar o êxito assombroso que o judicial case management teve no common law, sobretudo na Inglaterra, reduzindo a litigiosidade excessiva.

O case management é definido como o "planejamento da condução de demandas judiciais para a mais adequada resolução dos conflitos com o menor dispêndio de tempo e recursos", calcado no controle judicial da condução dos feitos e origanização da unidade

\footnotetext{
${ }^{143}$ A este respeito, vide MACIEL, A. F., Restrição...cit., p. 09.

144 MESSITTE, Peter J. The writ of certiorari: deciding which cases to review. USINFO: Washington, 29.07.2008, disponível em: http://iipdigital.usembassy.gov/st/english/publication/2008/08/20080814211720xjyrrep0.5789301.html\#axzz 3JvhILTj8, acesso em 23.11.2014.

${ }^{145}$ BAUM, Lawrence. A Suprema Corte americana. Trad. de Élcio Cerqueira. Rio de Janeiro: Forense Universitária, 1987, p. 247.

${ }^{146}$ PINTO, V. M. F., op. cit., p. 138.
} 
judiciária, envolvendo, entre outras medidas, o planejamento do fluxo procedimental e tentativas de composição amigável ${ }^{147}$.

Na Inglaterra, o tema ganhou destaque a partir de 1996, quando foi citado no Relatório do Lorde Woolf ${ }^{148}$, vindo a ser ineditamente consagrado nos Civil Procedure Rules (CPR) do processo civil inglês de 1998, que, acolhendo as conclusões do Relatório, fez com que o case management se tornasse dever geral das cortes inglesas. Nos EUA, passou a ser amplamente debatido um pouco antes, desde a década de $70^{149}$.

Isso explica um pouco do sucesso que a figura dos precedentes, e a técnica de julgamento tendo eles por base, desfruta nos países que aderiram ao common law, e que modernamente tem se espalhado também por famílias jurídicas de origem romano-germânica.

Vamos às razões subjacentes a tal sucesso, muito calcadas no desiderato de uniformização jurisprudencial.

\subsubsection{O precedente judicial como fonte do direito nos sistemas modernos de common law e civil law: estabelecendo premissas em torno da uniformização jurisprudencial}

A despeito de serem tradicionalmente associados aos sistemas de common law, pautados na doutrina do stare decisis, os precedentes judiciais constituem verdadeira e indispensável fonte do direito ${ }^{150}$ também nos países que seguiram a tradição romano-germânica, isto é, nos ordenamentos de civil law, como foi demonstrado alhures.

Deixar de atentar para sua relevância histórica e contemporânea consistiria em desconsiderar fundamental aspecto da justificação jurídica, tal como bem exposto por Robert AlEXY, tanto é que, hodiernamente, mesmo na lei continental europeia, ao menos

\footnotetext{
147 SILVA, Paulo Eduardo Alves da. Gerenciamento de processos e cultura de litigância: a experiência do case management inglês. In: SALLES, Carlos Alberto de (coord.). As grandes transformações do processo civil brasileiro: homenagem ao Professor Kazuo Watanabe. São Paulo: Quartier Latin, 2009, p. 636.

${ }^{148}$ WOOLF, Access to Justice Final Report - Final Report to the Lord Chancellor on the civil justice system in England and Wales, 1996. Disponível [online] em http://www.dca.gov.uk/civil/final/index.htm.

${ }^{149}$ Idem, p. 637.

${ }^{150}$ Segundo a abalizada doutrina de José Rogério CRUZ E TUCCI, a locução fonte do direito tem acepção dúplice, porquanto dela se pode extrair (i) a origem do direito objetivo e (ii) o veículo de conhecimento do direito, do que resulta que, pelo viés histórico, é possível falar-se em fonte de cognição como representação de toda experiência jurídica do passado ou do locus onde ela se revela. (TUCCI, José Rogério Cruz e. Precedente judicial como fonte do direito. São Paulo: RT, 2004, pp. 18-19).
} 
a importância de fato dos precedentes é reconhecida; a discussão, entretanto, gira em torno de sua qualificação como fonte de lei ${ }^{151}$.

Neste contexto, é certo que cada ordenamento jurídico atribui maior ou menor valor a determinada fonte, e, na realidade jurídica, os precedentes desfrutam, para os juízes dos sistemas ancorados na tradição romanística, da mesma importância dada pelos juízes do common law. A questão acerca da natureza e hierarquia das fontes vai muito além da vontade do legislador, constituindo tema afeito à teoria e metodologia do direito ${ }^{152}$.

De fato, vários autores têm, por esse motivo, ampliado e aprofundado os estudos comparativos entre os sistemas do common law e civil law, sendo certo que a divisão estanque não mais prevalece, de modo que, conforme já aduziram BARBOSA MOREIRA ${ }^{153}$ e RICHARD POSNER ${ }^{154}$, não há sistemas puros, mas sim sistemas com traços marcantes, com características predominantemente anglo-saxônicas ou romano-germânicas.

A despeito de a distinção usual feita entre os dois sistemas residir no fato de que o common law é centrado nos precedentes, e, portanto, no juiz, permitindo então uma abordagem discricionária, ad hoc, dos problemas específicos que são trazidos à Justiça, ao passo que o civil law, por outro lado, tende a ser identificado como um corpo codificado de princípios gerais abstratos que controlam o exercício da discricionariedade judicial, GARY SLAPPER e DAVID KELLY apontam que tal diferenciação é um pouco extremista, sobretudo porque há uma tendência contemporânea, dos tribunais de common law, em invocar a lei ${ }^{155}$, assim como tribunais de civil law, caso do Tribunal de Justiça Europeu, têm reconhecido "cada vez mais os benefícios de estabelecer um corpo de jurisprudência" ${ }^{\text {"156. }}$.

151 ALEXY, Robert. Teoria da argumentação jurídica, trad. de Zilda Hutchinson Schild Silva. São Paulo: Landy, 2001, p. 258.

${ }^{152}$ TUCCI,J. R. C. e T., Precedente...cit., p. 22.

${ }^{153}$ BARBOSA MOREIRA, José Carlos. Notas sobre alguns aspectos do processo (civil e penal) nos países anglo-saxônicos. In: Temas de Direito Processual, sétima série. São Paulo: Saraiva, 2001.

${ }^{154}$ POSNER, Richard. An economic approach to the law of evidence. John M. Olin Law \& Economics Working Paper n. ${ }^{\circ} 66 . \quad$ University of Chicago. Disponível em http://www.law.uchicago.edu/Publications/Working/index.html. Acesso em 27.05.2012.

${ }^{155}$ Caso da Inglaterra, cuja atividade legiferante tem crescido exponencialmente nos últimos anos. Cf., a este respeito, JUNIOR, Otavio Luiz Rodrigues. Crise do europeismo leva tribunais britânicos de volta ao common law. Consultor Jurídico, 03.09.2014. Disponível [online] em http://www.conjur.com.br/2014-set03/direito-comparado-crise-europeismo-leva-tribunais-volta-common-law. Acesso em 04.09.2014.

${ }^{156}$ SLAPPER, Gary. KELLY, David. O sistema jurídico inglês, trad. de Marcílio Moreira de Castro. $1^{\mathrm{a}}$ ed. brasileira. Rio de Janeiro: Gen, Forense, 2011, p. 03. 
Nesse sentido também apontam MARINONI e Mitidiero, ao afirmarem que, no contexto das duas clássicas perspectivas que dividam o common law e o civil law, quais sejam, respectivamente o caráter constitutivo do precedente e o caráter declaratório da jurisprudência, não é mais "possível afirmar que a jurisdição é totalmente declaração ou totalmente constituição: trata-se, mais propriamente, de uma reconstrução da ordem jurídica". 157

Ademais, segundo os referidos autores, é justamente com base nos fundamentos do Estado Constitucional - segurança, confiança e igualdade - que deve ser atribuída força vinculante aos fundamentos determinantes das decisões judiciais, daí resultando a enorme representatividade dos precedentes atualmente ${ }^{158}$.

Em ambos os sistemas, pois, a preocupação maior é com a uniformização do direito ${ }^{159}$, e é nessa seara que se discute a eficácia maior atribuída ao precedente judicial vinculante no quadro das fontes do direito no âmbito dos países que adotam legislação escrita e codificada, caso brasileiro.

Como já apontava GuIDo SoARES, a diferença é metodológica: se no civil law o que se busca em primeiro lugar é a lei escrita e, subsidiariamente, a jurisprudência, no common law esta lógica tradicionalmente é invertida, recorrendo-se primeiro aos casos, para só então, em caso de lacuna, socorrer-se da lei escrita ${ }^{160}$.

Mas, como visto, essa metodologia tem sido um pouco atenuada, eis que também nos sistemas de direito moderno codificado foi verificada a presença não apenas de precedentes persuasivos, mas também de precedentes com eficácia vinculante, dentre os quais se destacam os arrêts de règlement do direito francês; os julgamentos das causas maiores da Rota Romana da Itália pré-unitária; o regime dos assentos da Casa da Suplicação no direito lusitano; e, ainda, o controle exercido pelo Tribunal Constitucional espanhol sobre as decisões que contrariam precedentes judiciais ${ }^{161}$.

${ }^{157}$ MARINONI, Luiz Guilherme; MITIDIERO, Daniel. O Projeto do CPC: críticas e propostas. São Paulo: RT, 2010, p. 164.

${ }^{158}$ Idem, p. 164.

159 Vide, por oportuno, VIGLIAR, José Marcelo Menezes. Uniformização de jurisprudência. São Paulo: Atlas, 2003.

${ }^{160}$ SOARES, Guido Fernando Silva. Common Law: introdução ao direito dos EUA. $2^{\mathrm{a}}$ ed. São Paulo: RT, 2000 , p. 39.

${ }^{161}$ TUCCI, J. R. C e., Precedente...cit., p. 23. 
Desse modo, a casuística, desde os mais remotos tempos, constitui "método cuja característica fundamental independe da época, do sistema jurídico ou da natureza da função exercida pelas pessoas que o empregam"162, do que deflui, por exemplo, que "no direito inglês a técnica do precedente encontra-se intimamente ligada às decisões judiciais porque os artífices da common law são os juízes; os protagonistas do direito romano, pelo contrário, foram sobretudo os jurisconsultos e a chancelaria imperial, que também atuavam mediante a observância do método casuístico", 163

Como corolário e decorrência lógica da aplicação do princípio da universalidade, a recepção e aplicação de uma decisão anterior em face de hipótese temporalmente posterior constitui, de certo modo, uma garantia da aplicação de outro sobreprincípio jurídico, que é a igualdade, porquanto casos substancialmente iguais são tratados analogamente, como componente lógico e indissociável do valor Justiça ${ }^{164}$.

Além disso, TuCCI bem pontua que "a máxima jurídica que é extraída da decisão anterior e que, como visto, constitui efetivamente o 'precedente', sofre um tal processo de generalização que se insere em uma categoria de dogma dotado de extensão lógica. Desse modo, o caso concreto julgado passa a ser apenas um exemplum dentro de um conjunto genérico de casos. "165

Com efeito, do iter lógico que o magistrado desenvolve ao proferir sua sentença, aliado à garantia constitucional de sua motivação, decorre que o raciocínio lógico nela efetuado deve ser considerado no contexto e como finalidade de resoluções das controvérsias no Direito, de modo que o Judiciário não cumpre sua missão institucional ao apenas julgar casos concretos, mas também deve atuar preventiva e prescritivamente, para que suas decisões sirvam de orientação para casos futuros.

A premissa central é a de que o precedente é uma realidade em sistemas jurídicos histórica e estruturalmente heterogêneos, que apresenta características próprias em diferentes legislações.

\footnotetext{
162 TUCCI, J. R. C e., Precedente...cit., p. 24.

163 VACCA, Letizia. Contributo allo studio del metodo casistico nel diritto romano. Milano: Giuffrè, 1982 , p. 38, apud TUCCI, J. R. C e., Precedente...cit., p. 24.

${ }^{164}$ ALEXY, R., op. cit., p. 259.

165 TUCCI, J. R. C e., Precedente...cit., p. 25.
} 
A questão, porém, enseja um debate mais amplo, porquanto traz uma imbricada tensão inerente ao tema, qual seja, aquela existente entre a desejada e desejável estabilidade do Direito, em contraposição à sua evolução, que certamente exige a alteração, em determinadas situações, da posição jurisprudencial dominante.

Está em jogo o que vários autores denominam de "certeza do direito", expressão que está relacionada à uniformidade, cuja ocorrência tem por pressuposto a existência prévia de um período de desuniformidade, a fim de que seja gerada, efetivamente, estabilidade. Por “certeza", LEWIS KORNHAUSER se refere à previsibilidade, e não à estaticidade, sendo certo que a aplicação prática do sistema de precedentes, ao menos no civil law, traz consigo inegável economia, reduzindo os adjustment costs $^{166}$.

Afinal, o que todo sistema deve propiciar a seus jurisdicionados é segurança e racionalidade, permeadas por elementos que dêem previsibilidade e nos quais se possa confiar. Justamente por isso que autores estrangeiros valorizam a uniformização jurisprudencial como forma de aumentar o poder da instituição responsável pela tomada de decisões, de tal maneira a criar uma consistência interna que acaba por assegurar credibilidade externa ${ }^{167}$.

Diferentemente do civil law, o arraigado respeito ao precedente vinculante no common law - inserido na tradição e praxe judiciária ${ }^{168}$ - possui outro viés e conotação: significa o fortalecimento do Estado de Direito, mas também o impedimento à perpetuação de más práticas, como a desobediência dos juízes às orientações, ou mesmo mudanças bruscas de opinião, como retrata STEPHEN MARKMAN ${ }^{169}$.

166 "To begin, distinguish 'certain' as 'predictable' from 'certain' as 'unchanging' or 'static'." (KORNHAUSER, Lewis A. An economic perspective on stare decisis. Kent Law Review 65, Chicago, 1989, p. 77).

${ }^{167}$ SCHAUER, Frederick. Precedent. Stanford Law Review n. 39, fev./1987, p. 600.

${ }^{168}$ TUCCI, J. R. C. e, Precedente...cit., p. 155.

169 “(...) that is, regard for precedent is necessary for the rule of law, but it is also necessary that bad principles not permanently embalmed the law. These necessities are always in tension with one another, and their resolution is always an imperfect one, involving a choice between relative evils." (MARKMAN, Stephen. Precedent: tension between continuity. In: The Law and the Perpetuation of Wrong Decisions, Texas Law Review of Law and Politics 8/283). 
Todavia, os juízes anglo-saxões respeitam os precedentes muito mais por receio de serem criticados do que propriamente pela existência de sanções ${ }^{170}$. Ao contrário, não há previsão de penalidades aos magistrados que decidem contrariamente à orientação sedimentada do stare decisis, apegando-se, todavia, muito mais à questão envolvendo a sua reputação, razão pela qual raramente se observa, na Inglaterra, o desrespeito sistemático a eles.

Feito esse breve aparte, não se pode confundir previsibilidade com diversidade jurisprudencial, a qual não é, de per si, nociva, muito pelo contrário.

A divergência jurisprudencial, em muitas oportunidades, pode ser extremamente saudável, a ponto de acarretar a revisão de determinada tese ou conceito jurídico, propiciando uma reflexão técnica e acurada que gera a revisão de uma dada orientação jurisprudencial. É o dinamismo do Direito em ação.

Em todos os sistemas contemporâneos, uma noção bem clara os permeia: o Direito deve sempre agir e ser direcionado em busca da manutenção do status quo, mas jamais pode se tornar imutável, sob pena de perpetuar desigualdade e, sobretudo, injustiças. Afinal, a ciência jurídica serve à sociedade, sendo necessário que a ela se adapte conforme as necessidades.

NEIL DUXBURY corrobora o ora sustentado, ao afirmar que a invocação de um precedente parece ser, muitas vezes, medida de justiça, mas em outras tantas oportunidades se revela um caminho cômodo para acobertar a covardia, ou respaldar a inércia ${ }^{171}$.

Por esse motivo, mesmo o common law não é estranho à mutação dos precedentes fixados. Há previsão das técnicas do distinguishing - não aplicação do precedente com base em uma determinada peculiaridade, que justifica o afastamento apenas naquele caso concreto, mas o precedente sobrevive - e do overrruling, este sim concernente à superação da regra afastada, com bem aponta Teresa Arruda Alvim Wambier ${ }^{172}$.

\footnotetext{
170 "Fear of informal criticism", segundo NEIL DUXBURY (The nature and authority of precedent, Camdrige: Cambridge University Press, 2008, p. 16).

171 "Sometimes pointing to a precedent was clearly a way of trying to be fair. But at other times I was sure it was the coward's way out or an excuse for inertia." (DUXBURY, N., op. cit., p. IX).

${ }^{172}$ WAMBIER, Teresa Arruda Alvim. Precedentes e evolução do Direito. In: WAMBIER, Teresa Arruda Alvim (coord.). Direito jurisprudencial. São Paulo: Revista dos Tribunais, 2012, p. 40.
} 
A renomada autora traz à lume outra interessante reflexão em torno do tema. Afirma ela que, à medida que o Direito se aparelha para gerar maior previsibilidade, perde sua capacidade de adaptabilidade. E a recíproca é absolutamente verdadeira ${ }^{173}$.

Com efeito, em que pese uma aparente contradição entre essas duas características, deverão elas ser balizadas pela lei, pela doutrina e pela jurisprudência no direito brasileiro. É o diálogo das fontes que será responsável pela compatibilização e perfeita harmonia entre as noções citadas.

Por esse motivo, em outros sistemas de civil law, os precedentes bebem da fonte, e têm sua força valorativa, extraída de um conjunto de decisões no mesmo sentido, ou seja, que denotam o consensualismo refletido por um entendimento pacificado de determinado tribunal. Como decisão isolada, todavia, o precedente tem aplicação extremamente subsidiária no civil law.

Assim é que se torna necessário definir o que se considera "precedente", sempre tendo em mente sua dimensão temporal, como bem apontado por MiChELE TARUFFO, de que dele é extraída uma regra a ser aplicada como critério decisional em casos semelhantes futuros, ou seja, a identidade existente entre dois casos sucessivos, alongados no tempo, permite a aplicação da mesma regra de julgamento ${ }^{174}$.

No mesmo esteio caminhou TERESA WAMBIER, para quem “(...) a noção de precedente só tem razão de ser se se projeta no futuro a idéia de que este deve servir de parâmetro ou se isso efetivamente ocorre ${ }^{, 175}$.

Para TuCCI, "precedente judicial”, sob o ponto de vista técnico-processual, significa " $a$ decisão individualizada de um caso concreto, da qual se extrai uma tese jurídica que constitui o cerne do respectivo provimento, ou seja, a determinada ratio decidendi,

\footnotetext{
${ }^{173}$ WAMBIER, T. A. A., Precedentes...cit., p. 15.

174 "Peraltro, come spesso accade, la quantità condiziona la qualità, il che porta appunto ad individuare una differenza qualitativa tra precedente e giurisprudenza. Il precedente fornisce una regola (universalizzabile, come già si è detto) che può essere applicata come critério di decisione nel caso sucessivo in funzione della identità o - come accade di regola - dell'analogia tra i fatti del primo caso e i fatti del secondo caso". (TARUFFO, Michele. Precedente i giurisprudenza. Napoli: Editoriale Scientifica SRL, 2007, pp. 13-14).

${ }^{175}$ WAMBIER, T. A. A., Precedentes...cit., p. 42.
} 
prestando-se a predeterminar ou apenas nortear futuros julgamentos sobre idêntica questão",176.

A repercussão que os precedentes têm para os futuros julgamentos relaciona-se ao que esse autor chamou de "dimensão de eficácia" dos precedentes, e se tornou um fenômeno extremamente difuso, dada sua presença e relevância para os ordenamentos contemporâneos, "cada vez mais reforçado pela função de interpretação e aplicação uniforme (nomofilácica) do direito pelas Supremas Cortes ${ }^{, 177}$.

Justamente por se tratar de uma dimensão, há degraus ou parâmetros de eficácia das decisões judiciais em relação aos julgamentos posteriores, os quais são chamados de "degrees of normative force" para a doutrina estrangeira ${ }^{178}$.

Partindo da premissa de que todo e qualquer precedente judicial deve ser pensado a partir da realidade de cada ordenamento jurídico, como bem expõe Evaristo Aragão SANTOS $^{179}$, é extremamente perigoso simplesmente importar a teoria do precedente de qualquer país adepto do common law sem ter a precisa dimensão das diferenças entre esse sistema e aqueles integrantes do civil law. Sobretudo porque nem mesmo os americanos e ingleses consideram existir uma concepção ampla, clara, sistemática e definida em torno do que é precedente judicial ${ }^{180}$.

Assim, é possível sustentar, logo de início, que há uma nítida diferença ontológica entre o precedente formado no Brasil e nos países do common law. Se no Brasil o precedente tem natureza eminentemente interpretativa, resultando da interpretação e aplicação da lei por um órgão judicial, no common law a realidade é completamente diferente, na medida em que, lá, o precedente também é admitido como fonte criadora de direito.

\footnotetext{
${ }^{176}$ TUCCI, José Rogério Cruz e. Parâmetros de eficácia e critérios de interpretação do precedente judicial. In: WAMBIER, T. A. A., Direito jurisprudencial...cit., p. 98.

${ }^{177}$ Idem, pp. 99-100.

178 TUCCI, J. R. C. e, Parâmetros...cit., p. 100.

${ }^{179}$ SANTOS, Evaristo Aragão. Em torno do conceito e da formação do precedente. In: WAMBIER, Teresa Arruda Alvim (coord.), op. cit., p. 137.

${ }^{180}$ TARUFFO, Michele. Dimensiones del precedente judicial. Paginas sobre justicia civil, n. 33. Madrid: Marcial Pons, 2009, p. 542.
} 
Não por acaso o precedente representa o ponto de referência normativo de toda a teoria do stare decisis, e, como diz TUCCI, projeta uma eficácia de altíssimo grau, afinal lá todo precedente tem efeito vinculante ${ }^{181}$.

Considerando que, por aqui, adotamos um sistema misto de precedentes, porquanto coabitam, pacificamente, precedentes com efeito meramente persuasivo e precedentes com efeito vinculante, o termo "precedente" também se apresenta, de certa maneira, polissêmico.

Ressalte-se, desde logo, que este não é o lugar-comum nos países de civil law, sendo certo que, neles, predomina a regra de que os precedentes são dotados de efeito meramente persuasivo. O que varia é o dito grau de eficácia persuasiva, que pode ser mais ou menor a depender do ordenamento estudado.

Evaristo SANTos defende a existência de duas acepções, uma mais ampla e outra estrita, a despeito de não enxergar, no atual estágio do nosso ordenamento jurídico, espaço para o conceito estrito. De todo modo, quando utilizado em sentido amplo, o precedente expressa a decisão (independentemente de ser vinculativa ou não) que tem potencial para influenciar a solução de casos futuros ${ }^{182}$.

Tal conceito é incontestável também no direito comparado. Para DUXBURY, "a precedent is a past event which serves as a guide for present action" ${ }^{\prime 183}$; NEIL MACCARMICK e ROBERT SUMMERS caminham na mesma direção ao sustentar que "precedents are prior decisions that function as models for later decisions" ${ }^{184}$; e, por fim, LEONOR SORIANO retrata o precedente como "toda decisión judicial anterior relevante para la solución de casos futuros $" 185$.

A definição acima reverberada vai ao encontro do próprio senso comum, afinal é bastante usual, na praxe brasileira, falar-se que determinado tribunal "criou precedente" em determinado sentido, indicando a ideia de que certa decisão representa um norte ou

\footnotetext{
${ }^{181}$ TUCCI, J. R. C. e, Parâmetros...cit., p. 100.

${ }^{182}$ SANTOS, E. A., op. cit., pp. 143 e 145.

${ }^{183}$ DUXBURY, N., op. cit., p. 01.

184 MAC-CORMICK, Neil; SUMMERS, Robert (coords). Interpreting precedents: a comparative study. London: Dartmouth, 1997, p. 01.

${ }^{185}$ SORIANO, Leonor Moral. El precedente judicial. Madrid: Marcial Pons, 2002, p. 17.
} 
parâmetro para determinado entendimento. Ou seja, mesmo que atecnicamente, o precedente carrega consigo o senso de influência para soluções futuras.

Ainda no campo das breves (porém necessárias) digressões conceituais, também é imperioso destacar que as expressões "jurisprudência" e "precedente" não se confundem, tampouco podem ser utilizadas como sinônimas.

Rubens Limongi FrançA, desde há muito, apontara que a jurisprudência implica uma pluralidade de decisões, ou melhor, o conjunto de pronunciamentos do Judiciário, ou de um tribunal (recorte metodológico) "num determinado sentido, a respeito de certo objeto, de modo constante, reiterado e pacifico ",186.

A expressão, é inegável, abrange desde uma massa de decisões (sem uniformidade entre si) até um conjunto de decisões de certa forma direcionadas em torno de determinado tema. Daí falar-se, como o fez LUIz Rodrigues WAMBIER, em jurisprudência dominante ${ }^{187}$. Há, por assim dizer, uma acepção ampla e outra estrita também da jurisprudência, mas nenhuma delas se confunde com a de precedente.

Isso porque, de outra banda, "precedente" também tem sido empregado para designar um pronunciamento judicial que, em razão de sua autoridade e consistência, deveria ser adotado por outros juízes como padrão para a decisão de casos semelhantes ${ }^{188}$, isto é, tratase do precedente visto, verdadeiramente, como um paradigma.

Tampouco o precedente pode ser confundido com as súmulas. Afinal, as súmulas constituem produtos diretos da jurisprudência e são embaladas pela mesma metodologia jurídica, com as quais o direito brasileiro sempre conviveu, muito embora haja quem as critique por carecerem de efetividade prática, já que nem mesmo os juízes do tribunal que as produz estão obrigados a segui-las ${ }^{189}$.

Diferentemente daqui, no common law a acepção estrita do precedente judicial facilita a vida do intérprete, do julgador e das próprias partes (bem como de seus patronos), eis que o

\footnotetext{
${ }^{186}$ FRANÇA, Rubens Limongi. O direito, a lei e a jurisprudência. São Paulo: Ed. RT, 1974, p. 144.

${ }^{187}$ WAMBIER, Luiz Rodrigues. Uma proposta em torno do conceito de jurisprudência dominante. Revista de Processo n. 100, v. 25, São Paulo: RT, 2000, out.-dez./2000, pp. 72-87.

${ }^{188}$ SANTOS, E. A., op. cit., p. 145.

${ }^{189}$ MARINONI, L. G.; MITIDIERO, D., op. cit., p. 166.
} 
precedente judicial é considerado como a decisão vinculante para os casos posteriores, possuindo status assemelhado ao das normas jurídicas, de modo que a ausência do caráter vinculante impede que a decisão seja considerada precedente ${ }^{190}$.

Por lá, aliás, o precedente com efeito vinculante é mais identificado com a regra de julgamento que é extraída da decisão do que propriamente com a integralidade do seu conteúdo. É a ratio decidendi que importa no direito anglo-saxão, como aponta vasta doutrina $^{191}$.

Entretanto, a eficácia vinculante dos precedentes no sistema inglês só adveio nas primeiras décadas do séc. XIX, sendo o caso Beamisch v. Beamisch geralmente identificado pela doutrina como sendo o leading case por meio do qual a House of Lords passou a ser ungida pela observância da sua própria autoridade proclamada por meio dos julgamentos $^{192}$.

A partir desses ensinamentos, alguns autores brasileiros têm tentado mesclar o conceito de precedente, falando em um "núcleo essencial" que seria obtido na decisão, capaz de servir como diretriz para a solução posterior de casos análogos ${ }^{193}$.

De todo modo, há uma diferença marcante entre os dois sistemas comparativamente considerados: enquanto no common law o que é dotado de eficácia vinculante é a rule of law, identificada com a ratio decidendi, no Brasil geralmente o que se torna vinculante é o entendimento extraído a partir da parte dispositiva das decisões.

Essa mesma essência, fazendo a necessária distinção entre o precedente e a jurisprudência coletivamente considerada, e chamando atenção para a ratio decidendi dos julgados, parece ter motivado o legislador ao permitir a interposição do recurso especial, que será tratado com mais vagar mais adiante, com base no dissídio jurisprudencial.

\footnotetext{
${ }^{190}$ Segundo ROBERT SUMMERS, "in New York, the word precedent is used in a variety of ways, but when used most strictly, precedent means binding decisions of the same appellate court". (SUMMERS, Robert. Precedent in the United States. In: MAC-CORMICK, N., SUMMERS, R., op. cit., p. 364).

191 "There is, however, another usage, almost as significant, according to which a precedent in a narrower sense is only a relevant case that is binding, and only that part of the case or opinion that actually binds." (BANKOWSKI, Zenon; MAC-CORMICK, Neil; MARSHALL, Geoffrey. Precedent in the United Kingdom. In: MAC-CORMICK, N., SUMMERS, R., op. cit., p. 323).

192 TUCCI, J. R. C. e, Parâmetros...cit., p. 102.

${ }^{193}$ Cf. DIDIER JR., Fredie; BRAGA, Paula Sarno; OLIVEIRA, Rafael. Curso de direito processual civil, vol. II. $5^{\text {a }}$ ed. Salvador: JusPodvum, 2010, p. 381.
} 
Expliquemo-nos: o cabimento deste recurso, quando houver divergência de entendimento da jurisprudência de dois ou mais tribunais, exige da parte recorrente a demonstração de que o precedente formado no seu caso concreto destoa de outro precedente de determinado tribunal. Precedente, aí, no sentido amplo, porquanto o legislador exige a comparação (cotejo analítico) entre decisões individualmente consideradas.

Fincados esses pilares, a grande dificuldade reside em interpretar os precedentes e deles extrair a orientação a ser futuramente seguida, o que é refletido em nosso sistema, no qual o desafio está em eleger qual é o entendimento paradigmático a ser seguido.

\subsubsection{A interpretação dos precedentes na doutrina do stare decisis}

Até o final do século XX, imperava a rigidez da técnica do stare decisis na Inglaterra, rigidez esta que era criticada pelos próprios ingleses.

Tal rigidez possuía raízes históricas. Afinal, as decisões judiciais, nos países anglo-saxões, sempre ostentaram enorme peso e relevância na comunidade jurídica, qualidades estas que eram ainda mais acentuadas quando determinada decisão reproduzia julgados que foram anteriormente proferidos ${ }^{194}$.

Mas nem sempre foi assim. TUCCI explica que, até o século XVIII, os Law Reports eram coletâneas particulares, permitindo-se aos juízes ampla discricionariedade para acolher ou não o precedente judicial ${ }^{195}$.

Posteriormente, em 1898 foi definitivamente reconhecida a doctrine of binding precedent, cuja origem remonta ao já citado caso Beamisch v. Beamisch, daquela feita por meio do caso London Tramways Company v. London County Council, no qual a House of Lords afastou, de uma vez por todas, o efeito autovinculante de suas decisões e reiterou o caráter de vinculação externa que elas trariam para as Cortes de instâncias inferiores ${ }^{196}$.

Mesmo naquele contexto, ficava clara a ideia subjacente de que o uso do precedente era indispensável para determinar o direito e sua aplicação aos casos individuais, mas os

\footnotetext{
${ }^{194}$ HALE, Matthew. The history of the common law of England. Chicago: Chicago University, 1971, p. 45.

195 TUCCI, J. R. C. e, Parâmetros...cit., p. 101.

196 TUCCI, J. R. C. e, Precedente...cit., pp. 161-162.
} 
próprios Law Lords reconheceram que a obediência cega aos precedentes poderia ocasionar injustiças no caso concreto, passando a permitir a revisão, em caráter excepcional, como medida de prudência ${ }^{197}$.

Mesmo no auge da época em que vigorava a aplicação da regra de julgamento tendo por base o precedente paradigmático, eram permitidas (raras) exceções de afastamento do precedente no caso concreto, sempre envolvendo situações de ofensa à racionalidade ou à lei divina, como apontou BLACKSTONE ${ }^{198}$.

Desta feita, a Inglaterra oscilou historicamente: primeiro, passou por uma fase relativamente liberal, alternou para a rigidez - fase em que a inalterabilidade dos entendimentos, ainda que extremamente antigos, passou a ser identificada como a desejada estabilidade do sistema - e, finalmente, passou a ser novamente severamente criticada justamente pela imutabilidade.

Uma das obras mais completas a retratar os sistemas de direito contemporâneo é a de RENÉ DAVID. O autor bem resume a regra do precedente na Inglaterra da seguinte forma: todas as decisões da Câmara dos Lordes são vinculantes, mas não para ela mesma, e foi justamente a declaração de 1966 (relatório do Lorde Woolf) que resguardou a possibilidade futura de revisão dos entendimentos manifestados anteriormente; todas as decisões da Court of Appeal, por sua vez, são obrigatórias para as jurisdições inferiores, mas não atingem a própria Corte em matéria penal. Por fim, as derivadas da High Court of Justice são também aplicáveis às jurisdições inferiores ${ }^{199}$.

A marcante mudança de rumos na doutrina do stare decisis, que passou, modernamente, a ser governada pelo princípio do precedente vertical com força obrigatória externa para todas as cortes inferiores, também foi reverberada por BARON PARKE JR., jurista inglês de escol, para quem as regras legais oriundas de princípios e precedentes judiciais devem ser aplicadas em prol da uniformidade, consistência e certeza ${ }^{200}$.

\footnotetext{
197 TUCCI, J. R. C. e, Parâmetros...cit., pp. 102-103.

198 BLACKSTONE, William. Commentaries on the Laws of England, 9a ed., Londres: Cavendish, 2001, p. 51.

${ }^{199}$ DAVID, René. Os grandes sistemas do direito contemporâneo. $4^{\text {a }}$ ed. São Paulo: Martins Fontes, 2002, p. 151.

${ }^{200}$ Mirehouse v. Rennell (1833), apud TUCCI, J. R. C. e, Parâmetros...cit., p. 103.
} 
Todavia, a flexibilização era uma medida necessária, tal como ocorre com maior naturalidade no civil law por meio do revirement ${ }^{201}$, e passou a ocorrer, ainda que timidamente, em 1966, por meio de uma declaração do Chancellor Lord Gardner, permitindo à House of Lords rever seus próprios precedentes, "se assim parecesse correto proceder ${ }^{, 202}$.

WAMbiER aponta que, desde então, menos de dez precedentes foram explicitamente "overruled", em que pese várias outras alterações por meio de outras técnicas (distinguishing, explaining e reinterpreting) ${ }^{203}$.

A mudança foi muito bem recebida pela doutrina, que chegou a considerá-la como responsável por retirar do sistema o que ele de pior tinha. E isso se deve, em grande medida, porque na Inglaterra é muito comum haver longuíssimas transcrições nas decisões dos tribunais de casos anteriores que remontam aos idos de 1400, por exemplo ${ }^{204}$.

Há que se mencionar que a prática do overruling é muito mais recorrente nos EUA do que na Inglaterra, onde o sistema de precedentes é visto com ares de concretude (strong cement). Além disso, o overruling, quando ocorre no sistema inglês, nem sempre se dá maneira explícita, tanto assim que autores o descrevem como uma alteração lenta e gradual, podendo se estender por anos ${ }^{205}$.

Nos EUA, aliás, é tão arraigado o overruling que se permite o chamado "antecipatory overruling”, por meio do qual os juízes de instâncias inferiores alteram a regra de julgamento nas situações em que vislumbram a possibilidade de modificação do entendimento pelo tribunal superiores. Daí seu caráter antecipado.

Ao lado do antecipatory overruling, existem outras exceções à regra do precedente com efeito vinculante, quais sejam: (i) retrospective overruling, cuja revogação projeta efeitos ex tunc, ou seja, o paradigma não mais poderá ser invocado quando do julgamento de casos

\footnotetext{
201 TUCCI, J. R. C. e, Parâmetros...cit., p. 107.

202 "From a previous decision when it appears right to do so".

${ }^{203}$ WAMBIER, T. A. A., op. cit., p. 41.

${ }^{204}$ Em Bottomley v. Banniester, de 1932, foram citados precedentes de 1425.

205 “(...) extended over the years, over a long period; the erosion of a precedent is gradual. The overruling did not effect an abrupt change in the law; it rather recognized a 'fait accompli'." (BENDITT, Theodore, The rule of precedent. In: Laurence Goldstein (coord.), Precedent in law, Clarendon Paperbacks, Oxford University Press, p. 08, apud WAMBIER, T. A. A., Direito jurisprudencial...cit., p. 42).
} 
pretéritos e ainda não julgados; e (ii) prospective overruling, operando efeitos ex nunc, isto é, a revogação só produzirá efeitos com relação aos casos futuros, mantendo-se o paradigma válido e aplicável para fatos anteriores ${ }^{206}$.

Marinoni e MitidiERo, neste esteio, apontam para essa tendência recente, na prática judicial estadunidense, de negar a retroatividade a determinadas decisões, em prol do prestígio aos princípios da segurança (na vertente da previsibilidade) e da confiança, o que contraria a regra tradicional da irretroatividade dos precedentes, dominante por lá durante muitos anos.

Entretanto, apontam os citados autores que, mesmo nessas situações, poderão advir custos ou prejuízos, mormente quando os efeitos do overruling só podem ser produzidos a partir de certa data ou quando o overruling tem efeitos retroativos limitados a um determinado caso. Na primeira hipótese, porque todos os casos posteriores (seja antes ou depois do marco temporal, serão tratados de modo diverso, e na segunda hipótese todos os casos passados ficam em dessintonia com relação àquele específico para o qual o entendimento do precedente será aplicado) ${ }^{207}$.

É possível ocorrer, também, a postergação dos efeitos do precedente unicamente para um momento futuro, chamado de "prospective prospective overruling”. Completando a trinca do "prospective overruling”, há outra divisão à qual a doutrina alude, que diz respeito ao "pure prospective overruling”, referindo-se aos casos em que a Corte não aceita que o novel entendimento seja aplicado ao caso sob julgamento. Assim é que "prospective overruling", singularmente, indica a irretroatividade pura e simples.

Diante dessas considerações, o direito norte-americano, em que pese consagrar a doutrina do binding precedent tal como na Inglaterra, o faz em escala muito menor e mais flexível, permitindo a superação do precedente consagrado sempre que ele se revelar anacrônico ou errôneo.

\footnotetext{
${ }^{206}$ TUCCI, J. R. C. e, Parâmetros...cit., p. 109.

${ }^{207}$ Idem, p. 170.
} 
Entretanto, no âmbito do decisional law ${ }^{208}$ americano costumam também ser mencionados os "superprecedentes", que são, desde o séc. XIX, tão consagrados pela Suprema Corte que não devem sofrer "quaisquer distúrbios". Exemplo clássico é o caso Marbury v. Madison, sobre controle de constitucionalidade ${ }^{209}$.

Isto posto, a despeito dessa singular diferença, o que é comum a ambos os sistemas é a vinculatividade que decorre da ratio decidendi extraída da decisão, ou holding, segundo falam os americanos. William Landes e RiChard PoSNER o definem como sendo a regra mínima, quer explícita ou não, que é necessária para explicar o resultado do julgamento $^{210}$.

Com o passar dos anos e das fases citadas, a própria regra do precedente evoluiu no âmbito do common law e passou a ser aprimorada. Um exemplo claro disto é o de que a própria ratio decidendi nem sempre foi tida como a diretriz mais importante a ser seguida.

De toda sorte, a ratio decidendi constitui a essência da tese jurídica suficiente para decidir o caso concreto. É a regra de direito que vincula os julgamentos futuros inter alia. Prosseguindo no tema, TUCCI aponta que três elementos a integram: (i) indicação dos fatos relevantes (stating of material facts); (ii) raciocínio lógico-jurídico da decisão (legal reasoning); e (iii) o juízo decisório em si (judgement) ${ }^{211}$.

Contudo, não é o próprio órgão julgador que se ocupa de extrai-la durante o julgamento. Cabe aos juízes, quando forem examiná-la já na condição de precedente, extrair a norma legal que poderá ou não incidir na situação concreta ${ }^{212}$.

A rigor, portanto, stare decisis significa a submissão ao precedente, a conformação às rationes neles contidas.

\footnotetext{
${ }^{208}$ HAZARD, Geoffrey C.; TARUFFO, Michele. American civil procedure: an introduction. New Haven: Yale University, 1993, p. 37.

${ }^{209}$ TUCCI, J. R. C. e, Parâmetros...cit., p. 107.

210 "A holding is the minimum rule (whether or not expressly articulated) necessary to explain the outcome of the case." (LANDES, William M.; POSNER, Richard A. Legal precedent: a theoretical and empirical analysis. The Journal of Law and Economics, n. 19, 249, 1976, p. 250).

${ }^{211}$ TUCCI, J. R. C. e, Parâmetros...cit., p. 123.

${ }^{212}$ Idem, p. 123.
} 
Ainda que a expressão contenha, inegavelmente, um conteúdo descritivo (demonstração do raciocínio utilizado pela Corte para chegar à conclusão jurídica) e prescritivo, bem como aponta TERESA WAMBIER ${ }^{213}$, é da última vertente que os autores costumam se ocupar, sem olvidar dos obiter dicta, cujo efeito é meramente persuasivo.

Pois bem.

DWORKIN se ocupou de demonstrar e explicar que a ratio decidendi equivale à rule, que é criada a partir de um caso novo, para o qual nenhum precedente deve ser aplicado. Todavia, destaca o autor que a rule só será definida na decisão subsequente ${ }^{214}$.

Nos casos difíceis, porém, há um grande desafio posto aos intérpretes, em especial para identificar e entender qual a ratio aplicada naquele caso concreto. Isso porque muitas vezes é confundinda a razão da decisão com a razão para decidir. DUXBURY, neste ponto, assevera que "ratio decidendi can mean either reason for decision or reason for deciding. Judicial reasoning may be integral to the ratio, but the ratio itself is more than the reasoning ${ }^{, 215}$.

Tal dificuldade é ainda mais acentuada na Inglaterra, local em que, como dito, as decisões são notoriamente longas; ademais, não há formulação de acórdãos, o que certamente dificulta a empreitada de identificação da ratio.

Por outro lado, o modelo da Suprema Corte americana é marcado pela existência de acórdãos que indicam a posição dominante fruto do julgamento (single majority judgement). Em determinadas hipóteses, tal como sói ocorrer no direito brasileiro, é permitida a declaração de votos dos outros ministros, sejam eles complementares ao do relator, ou ainda votos vencidos.

Nos EUA, de tal forma a ser caracterizado e poder operar como precedente, a decisão deve ter sido proferida por maioria dentro do próprio tribunal, caso contrário terá efeito meramente persuasivo, assim como a mesma regra vale para decisões emitidas por Corte recursal de outro estado ou de Corte federal que seja de circunscrição diversa.

${ }^{213}$ WAMBIER, T. A. A., op. cit., p. 43.

${ }^{214}$ DWORKIN, Ronald. Taking rights seriously, Cambridge: Oxford University Press, 1978, p. 111.

${ }^{215}$ DUXBURY, N., op. cit., p. 68. 
Assim como no direito inglês, será vinculante apenas a parte que efetivamente resolver o mérito do litígio, isto é, o princípio de direito ou regra de direito que foi aplicado aos fatos relevantes para a decisão com base na questão jurídica ou questões apresentadas para a Corte para decisão (as alegações despiciendas são dicta).

Cabe apontar, entretanto, que a aplicação do precedente não é automática, o que, de pronto, é suficiente para afastar críticas comumente tecidas em torno do engessamento dos magistrados que a doutrina do stare decisis poderia ocasionar.

É fundamental haver a análise do caso concreto, para aferir se há similitude entre os dois casos que permita a aplicação da mesma solução jurídica anteriormente esposada. Portanto, será sempre possível que o julgador demonstre que a lide destoa do caso do precedente, afastando, destarte, sua incidência, ao já mencionado "distinguishing”, verdadeiro método comparativo $^{216}$.

Independentemente do modelo estudado, a confusão muitas vezes decorrente da identificação errônea da ratio decidendi e dos obter dicta é alvo de reflexão no common law, sendo válido chamar atenção para uma das teorias formuladas a este respeito, de Michael Abramovicz e Maxwell Stearns.

Para eles, por ratio decidendi deve-se entender o que foi efetivamente decidido (ainda que não tenha sido expressamente declarado, isto é, holdings implícitos), aí incluído todos os fatos e as conclusões que o tribunal considerou no processo de tomada de decisão ${ }^{217}$.

Essas ponderações embasam e contribuem, em muito, para tentar compreender alguns dos obstáculos levantados no Brasil quanto à importação de institutos de direito comparado como forma de proceder à uniformização da jurisprudência.

Uma das questões suscitadas diz respeito à vinculação por "identidade absoluta", ou seja, a exigência de que haja identidade integral das situações - tanto os fatos como a questão jurídica, modelo que é adotado nos países de common law.

216 BURNHAM, William. Introduction to the law and legal system of the United States. St. Paul, MN: Thomson West, 2006, p. 69.

217 ABRAMOVICZ, Michael; STEARNS, Maxwell. Defining dicta. Stanfor Law Review, mar./2005, p. 1068. 
Segundo pondera WAMBIER, saber quando os casos são iguais, ou determinar quais os critérios pelos quais dois casos devem ser considerados iguais, é algo a ser debatido principalmente para auxiliar as situações em que haja padrões flexíveis de decidibilidade, no que a autora chama de "ambientes decisionais frouxos". 218

A identidade integral dos casos, ao que parece, só faz sentido nos países do common law, nos quais são os juízes, ao decidirem, que criam a lei, e a regra. Assim, afigura-se salutar que os tribunais brasileiros profiram decisões reconhecendo a existência de identidade essencial entre os precedentes.

Independentemente do modelo que se adote, quer da identidade absoluta ou essencial, pode-se chegar à conclusão de que a uniformização da jurisprudência é tarefa que pode ser atingida tanto horizontal como verticalmente. Horizontalmente, por meio da decisão conjunta de vários casos ou através do método comparativo, em que são eleitos paradigmas cujas decisões norteiam os entendimentos subsequentes; verticalmente, por intermédio da súmula vinculante, instituto de marcadas raízes anglo-saxãs que foi introduzido no direito brasileiro a partir de 2004 e que será estudado no capítulo seguinte deste Trabalho.

Por derradeiro, todos os elementos acima descritos permitiram a visualização da existência de uma saudável interface entre os sistemas de civil law e common law, mostrando que ambos os sistemas estão alinhados quanto à necessidade de promover, ao máximo, a uniformização jurisprudencial.

Tanto é verdade que, nos EUA, existe uma coletânea privada - publicada pelo American Law Institute - intitulada Restatement of the Law, que vem ao encontro do papel uniformizador exercido pela jurisprudência americana, eis que, nas palavras de RENÉ DAVID, "procura, nas matérias em que as intervenções do legislador não foram muito numerosas, expor, de modo tão exato quanto possível, as soluções que estão em maior harmonia com o sistema da common law americana e que, por conseguinte, merecem ser consagradas pelos tribunais americanos ${ }^{, 219}$.

\footnotetext{
${ }^{218}$ WAMBIER, T. A. A., op. cit., p. 60.

${ }^{219}$ DAVID, R., op. cit., pp. 492-493.
} 
Trata-se de clara aproximação com os ordenamentos codificados, cuja semelhança pára neste exato ponto: o Restatement não desfruta de qualquer autoridade legal ou judicial, jamais sendo usado como um código verdadeiro. Algumas das decisões nele contidas podem até ser citadas em meio a certos julgamentos, mas não é nelas que os magistrados americanos buscam a solução do caso concreto.

De toda sorte, vê-se que cada um dos sistemas, no ambiente jurídico moderno, busca soluções, inspira-se e bebe na fonte do outro, sempre em prol da uniformização jurisprudencial, sendo os precedentes um instrumental imprescindível para atingir essa finalidade. 


\section{OS PRECEDENTES E OS TRIBUNAIS SUPERIORES NO DIREITO BRASILEIRO}

\subsection{Breve evolução histórica: o STF e a criação e do STJ}

No início da colonização do Brasil, foram concedidas capitanias hereditárias, mediante cartas de doação e respectivos forais, entre 1534 e 1536, responsáveis por formar a primeira organização política e judiciária do país.

Com o fracasso desse sistema, porém, D. João III determinou, em 1548, a criação de um Governo-Geral, expedindo-se quatro regimentos, destinados ao Governador-Geral (Tomé de Souza), ao Provedor-Mor, ao Ouvidor-Geral e aos Provedores Parciais.

Proclamada a independência do Brasil, a Constituição de $1824^{220}$ criou o Supremo Tribunal de Justiça, integrado por 17 juízes, o qual subsistiu até 27 de fevereiro de 1891.

A denominação "Supremo Tribunal Federal" foi adotada somente na Constituição Provisória publicada com o Decreto n. ${ }^{\circ}$ 510, de 22 de junho de 1890, e foi repetida no Decreto n. ${ }^{\circ} 848$, de 11 de outubro do mesmo ano, o qual organizou a Justiça Federal.

Segundo Rodrigo Garcia DA FonSECA, ele foi criado "à imagem da Supreme Court dos EUA. Várias eram as semelhanças originais, e embora as atribuições do nosso Supremo Tribunal tenham se modificado ao longo do tempo, permanecem muitas simetrias com as funções exercidas pela Suprema Corte Norte-Americana ${ }^{, 221}$.

Já a Constituição promulgada em 24 de fevereiro de 1891, que instituiu o controle da constitucionalidade das leis, dedicou ao Supremo Tribunal Federal os artigos 55 a 59, sendo que a Corte era inicialmente composta por quinze ministros, nomeados pelo Presidente da República com posterior aprovação pelo Senado, de forma semelhante aos moldes atuais. Entretanto, após a Revolução de 1930, o Governo Provisório decidiu, pelo

\footnotetext{
220 “Art. 163: Na Capital do Império, além da Relação, que deve existir, assim como nas demais Províncias, haverá também um Tribunal com a denominação de Supremo Tribunal de Justiça, composto de Juízes letrados, tirados das Relações por suas antiguidades; e serão condecorados com o título de Conselho. $\mathrm{Na}$ primeira organização poderão ser empregados neste Tribunal os Ministros daqueles que se houverem de abolir."

${ }^{221}$ FONSECA, R. G. da. op. cit., p. 204.
} 
Decreto n. ${ }^{\circ} 19.656$, de 3 de fevereiro de 1931, reduzir o número de ministros para onze.

A Constituição de 1934 mudou a denominação do órgão para "Corte Suprema" e manteve o número de onze ministros, mas a Carta de 1937 restaurou o título "Supremo Tribunal Federal".

No período do regime militar, o Ato Institucional n. ${ }^{\circ}$ 2, de 1965, aumentou o número de integrantes para dezesseis, acréscimo mantido pela Constituição de 1967. Com base no Ato Institucional n. ${ }^{\circ}$, de 1968, foram aposentados, em 16 de janeiro de 1969, três Ministros.

Posteriormente, o Ato Institucional n. ${ }^{\circ}$ 6, de $1^{\circ}$ de fevereiro de 1969 , restabeleceu o número de onze ministros, mantido até os dias atuais.

Com a restauração da democracia, a Constituição ora vigente, promulgada em 05 de outubro de 1988, realçou expressamente a competência precípua do Supremo Tribunal Federal como guardião da Constituição, dedicando-lhe os artigos 101 a 103.

Por fim, na CF/88 foi criado o Superior Tribunal de Justiça (STJ), descendente direto do antigo Tribunal Federal de Recursos (TFR), o qual foi uma das grandes novidades da Carta de 1947, após o chamado Estado Novo, para funcionar como segunda instância da Justiça Federal $^{222}$.

Segundo Dinamarco explica, o sistema então vigente ia perdendo legitimidade entre as instituições do País e perante os valores da Nação, sendo que a confiança nas soluções judiciárias andava em baixa, razão pela qual era necessário "alargar o canal de acesso à instância de superposição", sendo que o caminho encontrado foi a criação do novo tribunal, ideia essa, aliás, que não era nova, posto que já havia sido pensada durante o regime militar, em $1977^{223}$.

Feito este breve introito, cumpre-nos demonstrar qual a missão institucional-constitucional que lhes foi atribuída, vis-à-vis da competência recursal correlata.

\footnotetext{
222 Superior Tribunal de Justica. Disponível [online] em http://www.stj.gov.br/portal_stj/publicacao/engine.wsp?tmp.area=698. Acesso em 17.10.2012.

${ }^{223}$ DINAMARCO, Cândido Rangel. Superior Tribunal de Justiça e acesso à ordem jurídica justa. Revista de Processo n. ${ }^{\circ}$ 59, São Paulo: RT, jul.-set./1990, pp. 47-48.
} 


\subsection{Reflexões sobre a missão institucional-constitucional do STF e do STJ, os recursos de sobreposição e o problema da quantidade de recursos.}

Muito se falou, à época da Constituinte, da possibilidade de transformar o STF em uma Corte Constitucional assemelhada ao sistema europeu, mas ao final a escolha foi por ser um tribunal da federação, de inspiração norte-americana, tendo havido, segundo RoDRIGo FONSECA, "uma solução de compromisso, com a restrição de competências recursais do STF e a paralela ampliação de suas competências originárias, notadamente na área da jurisdição constitucional. "224

Assim, ao STF foi atribuído o controle de constitucionalidade das leis, ao passo que " $a$ função jurisdicional exercida pelo STJ representa culminância e o fim da atividade judicante em relação à inteligência de todo o direito federal de caráter infraconstitucional, (...) a última e definitiva palavra sobre o seu entendimento e a sua aplicação. ${ }^{, 225}$

O legislador nacional constituinte, ao eleger o Supremo Tribunal Federal como órgão de cúpula do Poder Judiciário, certamente optou por uma aproximação (ou transposição, como sustenta BRAGHITTONI ${ }^{226}$ ) com o modelo recursal extraordinário norte-americano, opção essa claramente revelada já na Constituição de 1891. E não foi só: a Constituição dos EUA serviu como paradigma para a nossa primeira Carta, de 1824, bem como para todos os demais países latino-americanos.

Nesse modelo, o STF detém uma tríplice função, quais sejam, de (i) figurar como órgão recursal da Justiça Federal, (ii) uniformizar a aplicação do direito federal e (iii) resguardar a supremacia da Constituição Federal. Sua real missão, portanto, reside nos remédios constitucionais e na ação de inconstitucionalidade.

\footnotetext{
${ }^{224}$ FONSECA, R. G. da. op. cit., p. 218.

${ }^{225}$ ALVIM, A., op. cit., p. 37.

226 "Inspirado, aliás, chega a ser um eufemismo, tão direta que foi a transposição do sistema entre lá e cá. E, na mesfma medida, nosso recurso extraordinário é cópia quase fiel do recurso que lá existe. Assim, revela-se para o Brasil de enorme importância tal comparação, até para avalar se poderia ser aqui utilizada alguma sistemática de 'filtro qualitativo' que, curiosamente, não trouxemos nem quando da criação do Supremo, nem quando da instituição do recurso extraordinário”. (BRAGHITTONI, Rogério Ives. Recurso extraordinário: uma análise do acesso do Supremo Tribunal Federal. São Paulo: Atlas, 2007, p. 16).
} 
Ambas as Cortes superiores brasileiras, portanto, têm raízes constitucionais, e assemelhadas, visando à proteção e uniformização do direito pátrio.

Neste esteio, válido repisar as lições dos eminentes ARNOLdo WALd e GiLMAR MENDES, em artigos vertendo sobre o papel da Suprema Corte, destacando as funções interpretativa, corretiva e construtiva que ela exerce sobre a Constituição, as leis, e a compatibilidade entre elas e a Carta Maior ${ }^{227-228}$

Em razão de circunstâncias históricas, cujo detalhamento foge ao escopo do presente trabalho, no caso brasileiro esses tribunais superiores oscilam entre um verdadeiro juízo de cassação, originariamente não jurisdicional, e uma terceira instância ordinária, alternativa essa que se harmoniza com a submissão do direito brasileiro à burocratização da função judicial.

Basta dizer, neste talante, que não é possível traçar um paralelo entre as Cortes de sobreposição europeias, brevemente descritas no capítulo precedente, e o papel dos nossos tribunais superiores, eis que, como salienta Humberto Theodoro Júnior, não contamos no Brasil com verdadeiros tribunais de cassação, mas sim com tribunais que realizam o rejulgamento das causas. Ao anular a decisão, as Cortes de Cassação europeias reenviam a causa a outro órgão jurisdicional, que aplica a tese jurídica firmada pela Corte em razão das peculiaridades do caso, ao passo que, aqui, os recursos de sobreposição se destinam a invalidar o julgamento impugnado e, se cabível, rejulgar a causa ${ }^{229}$.

\footnotetext{
227 “A função essencial da Suprema Corte consiste em interpretar a Constituição e as leis. Garantindo e fiscalizando a boa aplicação das normas jurídicas, pelos tribunais, e assegurando, assim, ao Direito, a necessária unidade, a adequada clareza e a imprescindível certeza, que são as condições essenciais da segurança jurídica que deve imperar no país. (WALD, Arnoldo. O Novo Supremo Tribunal Federal. In: SILVA, Christine Oliveira Peter da \& CARNEIRO, Gustavo Ferraz Sales (coords.). Controle de Constitucionalidade e Direitos Fundamentais - estudos em homenagem ao Professor Gilmar Mendes. RJ: Lumen Juris, 2010, p. 40).

228 "Dia após dia, o Supremo Tribunal Federal vem assumindo a responsabilidade política de aplicar a Carta de modo a tornar concretos os inúmeros direitos e garantias fundamentais constitucionalizados em 1988. E a corte tem respondido - o fará sempre - demonstrando profundo compromisso com o desenvolvimento desses direitos e corroborando, assim, a opção do constituinte pelo renovador princípio da esperança.” (MENDES, Gilmar Ferreira. A Constituição e a estabilidade democrática, Folha de São Paulo, 19.10.2008).

${ }^{229}$ THEODORO JÚNIOR, Humberto. Litigiosidade em massa e repercussão geral no recurso extraordinário. Revista de Processo n. ${ }^{\circ}$ 177, São Paulo: RT, nov./2009, p. 10.
} 
Assim é que, a partir de 1988, foram pensados os ditos "recursos de sobreposição" 230 ou recursos extraordinários lato sensu (recursos de direito estrito e fundamentação vinculada, como expõe RiCARdo de BARRos LEONEL ${ }^{231}$ ), gênero do qual os recursos extraordinário, especial e de revista são espécies.

Diferentemente dos recursos ditos ordinários, que permitem ampla rediscussão da causa, os recursos de sobreposição visam à tutela do direito objetivo - e esse "direito objetivo" causa espécie na doutrina e jurisprudência, principalmente pela tormentosa questão de distinguir entre questões de fato e de direito ${ }^{232}$. Os recursos extraordinários, assim, só podem versar sobre questões de direito.

Segundo José Ignácio Botelho de Mesquita aponta, com precisão, o que fez o constituinte foi dividir o recurso extraordinário em duas finalidades, separando a matéria constitucional da infraconstitucional, extraindo daí elementos para a criação do recurso especial e sua afetação ao STJ, como se um ato bíblico fosse ${ }^{233}$. MEDINA, a este respeito, considera que a criação dos recursos extraordinário e especial é ínsita à ideia de federalismo ${ }^{234}$.

Tal fato resulta da função dada aos nossos tribunais para que atuem como tribunais de direito, e não de fato. Por este motivo, temos a vedação ao reexame de matéria fática pelos tribunais superiores ${ }^{235}$, que inclusive editaram súmulas a este respeito ${ }^{236}$, que não têm o

\footnotetext{
${ }^{230}$ Expressão que tem origem no fato de os órgãos de superposição terem competência para "julgar recursos interpostos em causas que já tenham exaurido todos os graus das Justiças comuns e especiais", por isso é que se diz que eles se sobrepõem a elas. (CINTRA, Antonio Carlos de Araújo; GRINOVER, Ada Pellegrini; DINAMARCO, Cândido Rangel. Teoria geral do processo, 23a ed. São Paulo: Malheiros, 2007, p. 194).

${ }^{231}$ Sobre o tema, assevera RICARDO DE BARROS LeONEL que "pensar nos denominados recursos de superposição é pensar em recursos de estrito direito e de fundamentação vinculada, à medida que o recurso extraordinário (art. 102, III, da CF/88) e o recurso especial (art. 105, III, da CF/88) só podem ser interpostos nas estritas hipóteses tratadas nos permissivos constitucionais." (LEONEL, Ricardo de Barros. Recursos de sobreposição: novo procedimento e intervenção do amicus curiae. In: DIDIER JR., Fredie (coord). O terceiro no processo civil brasileiro e assuntos correlatos. Salvador: Juspodvum, 2010, p. 436).

${ }^{232}$ Voltaremos a essa questão no Capítulo 4, quando for abordada a jurisprudência defensiva.

${ }^{233}$ MESQUITA, José Ignácio Botelho de. Recurso extraordinário e recurso especial: contrastes e confrontos. In: FABRÍCIO, Adroaldo Furtado. Meio de impugnação ao julgado civil: estudos em homenagem a José Carlos Barbosa Moreira. $2^{\text {a }}$ ed. Rio de Janeiro: Forense, 2008, p. 358.

${ }^{234}$ MEDINA, José Miguel Garcia. O prequestionamento nos recursos extraordinário e especial. E outras questões relativas à sua admissibilidade e ao seu processamento. $4^{\mathrm{a}}$ ed. São Paulo: RT, 2001, p. 19.

${ }^{235}$ Para HuMBERTO THEODORO JúNIOR, em tais recursos de estrito direito "não se abre a possibilidade de rediscussão de matéria fático-probatória. Fala-se de recusos para os quais, tradicionalmente, se diz não cuidar de corrigir a 'injustiça' da decisão, mas, somente, garantir a integridade da Constituição e leis federais elou a uniformidade da jurisprudência". (THEODORO JÚNIOR, Humberto. Litigiosidade em massa... cit., p. 09).
} 
escopo de ensejar reexame da causa, mas tão somente das quaestiones iuris afeitas ao direito federal (constitucional, no caso do recurso extraordinário, e infraconstitucional no caso do recurso especial).

Segundo explica BARbosa MoreirA ${ }^{237}$, a finalidade do recurso constitucional pátrio é "assegurar a inteireza positiva, a validade, a autoridade e a uniformidade de interpretação da Constituição”, ao passo que a função do recurso especial, que antes era desempenhada pelo recurso extraordinário, é a manutenção da autoridade e unidade do direito federal, "tendo em vista que na Federação existem múltiplos organismos judiciários encarregados de aplicar o direito positivo elaborado pela União, ${ }^{\text {,238. }}$.

Fica, aqui, claramente revelada a função nomofilática de tais recursos, isto é, de defensores da integridade do ordenamento federal (STJ) e constitucional (STF).

O denominado recurso extraordinário, inspirado no writ of error do direito norteamericano $^{239}$, surgiu em 1890 , e permaneceu, durante quase um século, como recurso de competência exclusiva da Corte Suprema, criada na mesma data, com a função precípua de manter a unidade do direito nacional e o respeito à Constituição e à lei federal ${ }^{240}$. Adhemar Maciel também aponta o fato curioso de que, nos EUA, o writ of error foi substituído pelo writ of certiorari no ano seguinte à sua adoção aqui no Brasil, além de mencionar que o nosso recurso também buscou inspiração na apelación argentina ${ }^{241}$.

Justamente pelo fato de o STF ter sido idealizado à feição da Suprema Corte dos EUA, não surpreende que, desde há muito, o ex-Ministro VíTOR NUNES LEAL tenha defendido a

\footnotetext{
236 Súmulas 279 e 454 do STF: "Para simples reexame de prova não cabe recurso extraordinário"; "Simples interpretação de cláusulas contratuais não dá lugar a recurso extraordinário”. Súmulas 05 e 07 do STJ: "A simples interpretação de cláusula contratual não enseja recurso especial”; "A pretensão de simples reexame de prova não enseja recurso especial”.

${ }^{237}$ BARBOSA MOREIRA, José Carlos. Comentários ao Código de Processo Civil. Rio de Janeiro: Forense, Volume V, 2005, p. 180.

${ }^{238}$ THEODORO JÚNIOR, Humberto. Curso...cit., vol. I, p. 105.

${ }^{239}$ Segundo Ovídio BAPTISTA DA Silva, "nosso recurso extraordinário, como o writ of error do direito americano, são instrumentos jurídicos marcados pela modernidade, forjados, ambos, na cultura euripeia dos séculos XVII e XVIII, a expressarem a pesada influência do Iluminismo. Além disso, no caso brasileiro, o parentesco do recurso extraordinário com os juízos de cassação, nascidos na Revolução Francesa, não pode ser esquecido." (SILVA, Ovídio Araújo Baptista da. Questão de fato em recurso extraordinário. In: FABRÍCIO, Adroaldo Furtado (coord.). Meios de impugnação ao julgado civil: estudos em homenagem a José Carlos Barbosa Moreira. $2^{a}$ ed. Rio de Janeiro: Forense, 2008, pp. 486-487).

${ }^{240}$ GRINOVER, Ada Pellegrini. O controle do raciocínio judicial pelos Tribunais Superiores brasileiros. Revista AJURIS, n. ${ }^{\circ}$ 50, Ano XVII, nov./1990, p. 5.

${ }^{241}$ MACIEL, A. F., Restrição...cit., p. 10.
} 
adoção do writ of certiorari no sistema brasileiro ${ }^{242}$, sistemática essa que, confome descrita no capítulo precedente, exige que o recorrente convença o tribunal superior quanto às razões pelas quais seu recurso deve ser analisado.

Todavia, à época em que o recurso extraordinário foi introduzido no sistema brasileiro, não havia necessidade de se importar, para cá, o writ of certiorari, tampouco a doutrina do stare decisis, afinal o volume de processos não era insuportável ${ }^{243}$. Mas esse panorama definitivamente mudou, como vimos.

Isto posto, tem-se que a competência do STF vem definida no art. 102, III, da CF, incumbindo-lhe processar e julgar as causas decididas em única ou última instância, quando a decisão recorrida (i) contrariar dispositivo da $\mathrm{CF}$, (ii) declarar a inconstitucionalidade de tratado ou lei federal, (iii) julgar válida lei ou ato de governo local contestado em face da CF, e (iv) julgar válida lei local contestada em face de lei federal. Cumpre mencionar que esta última hipótese era, antes do advento da referida emenda constitucional, de competência do STJ.

Por outro lado, ao STJ, nos termos do art. 105, III, da CF, compete julgar, em recurso especial, as causas decididas, em única ou última instância, pelos tribunais regionais federais ou pelos tribunais dos Estados, DF ou Territórios (que não existem), quando a decisão recorrida ( $i$ ) contrariar tratado ou lei federal, ou lhes negar vigência, (ii) julgar válido ato de governo local contestado em face de lei federal e (iii) der a lei federal interpretação divergente da que lhe houver atribuído outro tribunal.

Com a edição da EC n. ${ }^{\circ}$ 45/04, ao STF passou a incumbir também o julgamento de causas nas quais a decisão recorrida julgar válida lei local contestada em face de lei federal, mantido na esfera de competência do STJ apenas o julgamento de questões que versem sobre a validade de ato do governo local, sendo a primeira expressão bem abrangente, incluindo toda norma estadual e municipal, coativa e de observância geral.

\footnotetext{
${ }^{242}$ FONSECA, R. G. da, op. cit., p. 211.

${ }^{243}$ PINTO, Valentina Mello Ferreira. A comparison between the writ of certiorari in the United States and the extraordinary appeal's general repercussion requisite in Brazil. Revista de Processo n. ${ }^{\circ}$ 187, ano 35, set./2010, p. 120.
} 
Devido à amplitude de hipóteses de cabimento do recurso especial, temia-se que ele se transformasse em um recurso genérico, pois são muitas as possibilidades em que se pode alegar divergência de interpretação da lei federal entre dois ou mais tribunais ${ }^{244}$.

Isso porque abaixo do STJ se encontram os tribunais de segundo grau da Justiça Federal e da Justiça Estadual, os quais se expandiram de modo excepcional, acompanhando o desenvolvimento e evolução da sociedade nacional. Além desse fator, que por si só já ensejaria aumento dos recursos destinados ao STJ, o desequilíbrio na repartição das competências legislativas entre União e Estados também aumentou assombrosamente as possibilidades que ensejam a interposição de recurso especial.

No Brasil, como salientado adrede, os recursos de sobreposição têm o condão tanto de invalidar quanto de exigir novo julgamento da causa, sendo certo que o Supremo Tribunal Federal e o Superior Tribunal de Justiça detêm esses poderes de cassação e de revisão ${ }^{245}$.

Para conseguir acesso às vias superiores no Brasil, é imprescindível que a decisão recorrida tenha sido proferida em última ou única instância e que não caiba recurso em plano inferior, sendo que o requisito da "causa decidida", tal como consta no texto constitucional, não significa apenas decisão de mérito, podendo ser causa de competência originária de tribunal, de julgamento de recurso, ou de caso de revisão obrigatória em segundo grau.

Para fins do recurso extraordinário, deve existir apontada violação constitucional, a qual deve ter sido previamente anteriormente enfrentada pelo tribunal a quo, não podendo ser

\footnotetext{
${ }^{244}$ MOREIRA Alves já diagnosticava: "não há Corte alguma que, sem algumas centenas de juízes, possa julgar, em terceiro grau de jurisdição, todas as questões de direito já apreciadas pelo duplo grau de jurisdição ordinária (...).” (MOREIRA ALVES, José Carlos. Poder Judiciário. A constituição brasileira (1988) - Interpretações, vol. I. Rio de Janeiro: Editora Forense Universitária, 1983, pp. 195-205).

${ }^{245}$ THEODORO JUNIOR, Humberto. Curso de Direito Processual Civil. Rio de Janeiro: Forense, 2010, p. 662. No mesmo sentido, cf. a seguinte citação de BARBOSA MOREIRA: "Note-se que o Supremo Tribunal Federal ou o Superior Tribunal de Justiça, em conhecendo do recurso, não se limita a censurar a decisão recorrida à luz da solução que dê à quaestio iuris, eventualmente cassando tal decisão e restituindo os autos ao órgão a quo, para novo julgamento. Fixada a tese jurídica a seu ver correta, o tribunal aplica-a à espécie, isto é, julga "a causa" (rectius: a matéria objeto da impugnação), como rezam o art. 324, fine, do regimento interno do Supremo Tribunal Federal - que não é mera norma "permissiva"-, e o art. 257, fine, do regimento interno do Superior Tribunal de Justiça. Nisso se distinguem os nossos recursos extraordinário e especial não apenas dos "recursos de cassação" de tipo francês, mas também do seu equivalente argentino, tal como tem funcionado na prática. Só quando o fundamento do recurso consista em error in procedendo é que o Supremo Tribunal Federal ou o Superior Tribunal de Justiça, ao dar-lhe provimento, anula a decisão da instância inferior e, se for o caso, faz baixar os autos, para que outra ali se profira. Salvo nessa hipótese, o acórdão do tribunal ad quem, seja qual for o sentido em que este se pronuncie, substitui, na medida em que se conheça da impugnação, a decisão contra a qual se recorreu; incide o art. 512." (BARBOSA MOREIRA, J. C., op. cit., p. 601).
} 
suscitada originariamente no recurso, de modo que o prequestionamento também se apresenta como requisito de admissibilidade do recurso extraordinário. A exigência se aplica igualmente ao recurso especial, de modo que a matéria suscitada deve ter sido enfrentada previamente pelo tribunal recorrido.

Neste tema, cabe um breve aparte.

O prequestionamento era exigido nas Constituições Federais de 1891, 1934, 1937 e 1946, mas foi abolido desde a Carta de 1967, sendo que, desde então, nunca mais voltou a ser previsto expressamente como requisito de admissibilidade dos recursos especial e extraordinário $^{246}$.

Todavia, faz-se presente no conteúdo das Súmulas 282, 317 e 356 do STF $^{247}$, todas elas elaboradas sob a égide da Constituição de 1946, como explica GALENo LACERDA ${ }^{248}$, e, mesmo assim, aplicadas atualmente tanto pelo STJ como pelo STF, que exigem que tal requisito tenha sido cumprido para que resulte o exame positivo de admissibilidade dos recursos de sobreposição.

O prequestionamento, basicamente, significa (i) a manifestação expressa do tribunal recorrido sobre determinado tema, (ii) o debate anterior à decisão recorrida acerca do tema ou (iii) a soma das duas tendências anteriores (prévio debate sobre a questão constitucional ou federal, seguido da manifestação expressa do tribunal a respeito) $)^{249}$.

Há quem sustente ser inconstitucional tal exigência ${ }^{250}$, eis que ofenderia os preceitos dos arts. 102, III, “a” ou 105, III, “a”, "b” e “c”, da CF, com o que MEDINA não concorda, por considerar que ela decorre do princípio dispositivo e do efeito devolutivo, servindo para

\footnotetext{
246 THEODORO JÚNIOR, Humberto. Recurso especial - prequestionamento. Revista Síntese de Direito Civil e Processual Civil n. ${ }^{\circ}$ 34, ano VI, São Paulo: IOB, mar.-abr./2005, p. 132.

247 Súmula 282: "É inadmissível o recurso extraordinário, quando não ventilada, na decisão recorrida, a questão federal suscitada".

Súmula 317: "São improcedentes os embargos declaratórios, quando não pedida a declaração do julgado anterior, em que se verificou a omissão”.

Súmula 356: "O ponto omisso da decisão, sobre o qual não foram opostos embargos declaratórios, não pode ser objeto de recurso extraordinário, por faltar o requisito do prequestionamento”.

${ }^{248}$ LACERDA, Galeno. Críticas ao prequestionamento. Revista dos Tribunais n. ${ }^{\circ}$ 758, São Paulo: RT, dez./1998, p. 75.

${ }^{249}$ MEDINA, José Miguel Garcia. Prequestionamento e repercussão geral: e outras questões relativas aos recursos especial e extraordinário, $5^{\mathrm{a}}$ ed. São Paulo: RT, 2006, pp. 112-120.

${ }^{250}$ LACERDA, G., op. cit., p. 81.
} 
instrumentalizar o conhecimento da questão federal ou constitucional pela decisão recorrida $^{251-252}$.

Dessa discussão decorre outra mais ampla, e que será estudada no capítulo seguinte, que são os mecanismos criados para restringir a admissibilidade dos recursos especial e extraordinário, sendo a exigência do prequestionamento um deles. MANCUSO é um dos que defendem uma restrição maior ${ }^{253}$, ao passo que DinAMARCo ${ }^{254}$ e MEDINA $^{255}$ defendem um abrandamento da exigência, no sentido idêntico ao do precedente já firmado pelo STF que reconheceu a flexibilização do prequestionamento nos processos cujo tema de fundo foi definido pelo Plenário, impedindo a superveniência de soluções diferentes em relação à decisão colegiada ${ }^{256}$.

Inobstante esse aparte, além de a matéria tida como violada dever ter sido devidamente prequestionada, o recorrente deve, para fins do recurso extraordinário, demonstrar a repercussão geral das questões discutidas no caso, além de deduzir expressamente o dispositivo constitucional pertinente ao recurso, tema este que será melhor explorado mais adiante. Linhas gerais, deve ser possível determinar com clareza do que se trata a controvérsia, caso contrário, seria aplicável a disposição da Súmula 284 que dispõe ser “inadmissível o recurso extraordinário, quando a deficiência na sua fundamentação não permitir a exata compreensão da controvérsia.".

Caso o STF não conheça do recurso, tal decisão será irrecorrível. Se conhecido o recurso, seja para negar-lhe ou conceder-lhe provimento, o acórdão proferido por este órgão substitui o recorrido, mesmo que o presente tenha tão somente confirmado o da instância inferior. Assim, o trânsito em julgado que sobrevenha será do acórdão do Supremo Tribunal Federal.

\footnotetext{
${ }^{251}$ MEDINA, José Miguel Garcia. O prequestionamento nos recursos extraordinário e especial, $2^{\mathrm{a}}$ ed. São Paulo: RT, 1999, p. 217.

252 Vide: SANTOS, Paula Ferraresi. Prequestionamento e sua aplicação nos Tribunais Superiores: uma análise crítica. Revista de Processo n. ${ }^{\circ}$ 216, ano 38, fev./2013, p. 404.

${ }^{253}$ MANCUSO, Rodolfo de Camargo. Recurso extraordinário e recurso especial. São Paulo: RT, 2001, p. 210.

${ }^{254}$ DINAMARCO, C. R., Superior Tribunal de Justiça...cit., p. 51.

${ }^{255}$ MEDINA, J. M. G., Prequestionamento...cit., p. 122.

${ }^{256}$ STF, AgRg no AI 375.011/RS, Relatora Ministra ELLEN GRACIE, DJ de 28.10.2004.
} 
Basicamente, as mesmas considerações tecidas sobre o recurso extraordinário são aplicáveis ao recurso especial, cujo procedimento é semelhante: como se disse anteriormente, tratam-se das duas faces da mesma moeda, uma voltada às violações à Carta Maior, e outra às violações à lei federal.

Devidamente delineada a competência do STF e do STJ, é de se notar que o excessivo volume de recursos pendente de julgamento não é "privilégio" de uma das Cortes, mas sim das duas, o que contrasta e dificulta o atendimento à missão constitucional que lhes foi designada.

Em que pese a criação do STJ em 1988, até hoje não foi solucionado o problema da sobrecarga de processos dos Tribunais Superiores brasileiros, tanto é que ARAKEN DE Assis asseverou sobre o tema que "o STJ não deu cabo da 'crise' do STF (...) Por sua vez, o STJ logo caiu na mesma crise, vergado pelo excesso de serviço, porque a própria finalidade de recurso especial obriga ao suplício imposto a Sísifo." 257.

Não é demais lembrar, inclusive, que o STJ foi criado justamente em um "momento de grande desproporção entre a solicitação de serviços e a capacidade de trabalho do STF (...) [que] era manifestamente insuficiente para acolher tanta solicitação”, como bem apontou CÂNDIDo RANGEL DiNAMARCo ${ }^{258}$.

Ou seja, o STJ foi criado para desafogar o STF, mas ambas as Cortes enfrentam o mesmo problema, tão importante no STF a ponto de o Ministro Luís BARROSo dizer que o Pretório Excelso enfrenta severa crise de funcionalidade e possui "três grandes gargalos" nos dias atuais que precisam, com a maior brevidade possível, ser sanados: (i) o congestionamento do Plenário, (ii) o acúmulo de processos com repercussão geral reconhecida, e (iii) o volume de habeas corpus $^{259}$.

Ao lado disso, é fato que, na prática forense recente, o STF em muito se distanciou do seu perfil de Corte Constitucional, passando a ser considerada praticamente como uma Corte recursal, eis que mais de $90 \%$ do que julga são recursos.

\footnotetext{
${ }^{257}$ ASSIS, Araken de. Manual dos recursos. $1^{\mathrm{a}}$ ed. São Paulo: Revista dos Tribunais. 2007, p. 757.

${ }^{258}$ DINAMARCO, C. R. Superior Tribunal de Justiça...cit., p. 54.

${ }^{259}$ Portal Migalhas, "STF se aproxima da terceira década...", op. cit., p. 02.
} 
Com efeito, o já citado estudo elaborado pela FGV, intitulado "Relatório Supremo em Números", aponta que há três perfis essenciais do STF, quais sejam, o recursal, constitucional $^{260}$ e ordinário ${ }^{261}$, sendo que há “apenas” 52 (cinquenta e duas) classes processuais que permitem a entrada no Supremo; dentre os perfis citados, o recursal é amplamente o que mais se destaca ${ }^{262}$.

Com efeito, entre 1988, i.e., desde a promulgação da CF, e 2009, 91,7\% dos processos que chegaram ao STF são recursos. Assim, quantitativamente o Supremo não é uma corte constitucional na forma originalmente pensada, razão pela qual ele mais se assemelha a uma "Corte recursal suprema", escolhida pela parte que a ela socorre ${ }^{263}$.

Nem sempre foi assim, porém, eis que logo nos dois primeiros anos de vigência da $\mathrm{CF}$, havia um equilíbrio entre os perfis ordinário e recursal, que foi sendo mudado ao longo do tempo, sobretudo pela intensa ligitiosidade que permeia a cultura jurídica brasileira.

Espantosamente, o estudo citado aponta que cerca de $90 \%$ de todos os processos em tramitação no STF advêm do setor público, sendo o Poder Executivo Federal seu maior usuário, com 68\% dos processos; logo, é o Poder Público o maior responsável por congestionar nossa Suprema Corte ${ }^{264}$.

A despeito de a súmula vinculante e a repercussão geral terem inegavelmente contribuído para a redução no volume total de processos - exemplificativamente, entre 2007 e 2010 o total caiu de 110 mil ao ano para 30 mil - outras medidas ainda precisam ser adotadas, principalmente porque o desequilíbrio entre os perfis foi apenas atenuado, temporariamente, tendo o panorama voltado a recrudescer desde então.

As possíveis soluções para os problemas apontados são auspiciosas, e algumas delas são relativamente simples de serem implementadas, a começar pelo aumento do número de magistrados e, consequentemente, de ministros, que há muito vem sendo aventado em sede

\footnotetext{
${ }^{260}$ Controle concentrado em abstrato de constitucionalidade, envolvendo ADC, ADI, ADO, ADPF, Mandado de Injunção e Proposta de Súmula Vinculante.

${ }^{261} V . g$., processos de competência originária.

${ }^{262}$ FALCÃO, J.; CERDEIRA, P. de C.; ARGUELHES, D. W., op. cit., p. 20.

263 Idem, p. 21.

${ }^{264}$ Consultor Jurídico. Estudo mostra que STF é Corte recursal. 04.05.2011. Disponível [online] em http://www.conjur.com.br/2011-mai-04/estudo-mostra-stf-corte-recursal-uniao-maior-usuario. Acesso em 16.09.2014.
} 
doutrinária ${ }^{265}$.

Com relação ao congestionamento do Plenário, que compromete a celeridade na atuação do $\mathrm{STF}^{266}$, foi aprovada, em 28.05.2014, emenda regimental transferindo a competência do Plenário para as Turmas de algumas matérias, incluindo o recebimento de denúncia ou queixa, ações penais contra Deputados e Senadores, ações contra o CNJ e o CNMP, bem como reclamações.

Na mesma sessão, os Ministros endereçaram a transferência de outros temas para as Turmas, formulando proposta para encaminhar todos os mandados de segurança, mandados de injunção, habeas data, ações envolvendo litígios estrangeiros entre Estados estrangeiros e a União, além de conflitos federativos, proposta esta que, caso aprovada, contribuirá para relegar ao Plenário funções típicas de uma Corte constitucional julgamento das ações diretas e das repercussões gerais.

Também a fim de desafogar o Plenário reside a proposta de que as medidas cautelares em ações diretas sejam julgadas pelo Plenário Virtual, quando tenham sido concedidas há mais de 5 (cinco) anos, sendo o julgamento realizado pelo Plenário Físico quando três ministros discordarem da proposta de julgamento virtual feita pelo relator. Segundo BARROso, tal medida vai ao encontro da estatística alarmante de que, em média, uma liminar concedida em ação direta vige por 4.914 dias, período superior a $13 \operatorname{anos}^{267}$.

A defesa da expansão do Plenário Virtual não pára por aí. Na visão do Ministro BARRoso, todos os agravos regimentais e embargos de declaração que são julgados em listas poderiam ser julgados virtualmente, afastando essa forma condenável de julgamento (por lista) e permitindo aos julgadores que tenham acesso ao voto do relator, antecipadamente, e possam efetivamente refletir sobre o caso, sem a massificação do julgamento.

Por fim, e a mais importante de todas, é a medida voltada ao equacionamento da repercussão geral, haja vista que, por mais contraditório que soe, o reconhecimento em demasia de repercussão geral aos recursos acaba por prejudicar a prestação jurisdicional, eis que causa o sobrestamento, por anos a fio, de milhares de processos que estão em

\footnotetext{
${ }^{265}$ MACIEL, A. F., Restrição...cit., p. 13.

${ }^{266}$ Em dezembro de 2013, havia 728 processos liberados pelos relatores aguardando inclusão em pauta.

${ }^{267}$ Conforme consta do III Relatório Supremo em Números, da FGV, anteriormente citado.
} 
trâmite perante as instâncias inferiores.

Os números, nessa temática, chamam atenção: segundo a Assessoria de Gestão Estratégia do STF, dos 757 processos submetidos ao reconhecimento de repercussão geral desde sua implementação, em 2007, até 12.09.2014, 529 tiveram repercussão geral reconhecida (quase $70 \%$ ), dos quais apenas 201 foram julgados (ou 38\%) ${ }^{268}$.

Diante desse panorama é que são formuladas as seguintes propostas: ( $i$ ) aumento de rigor no reconhecimento de repercussão geral até que o estoque anterior seja zerado; (ii) recursos devem ser selecionados com base em critérios comparativos, por semestre, e não à medida que são recebidos no STF; (iii) mudanças procedimentais simples, que dependem de mera alteração regimental, caso v.g. da pré-fixação dos cronogramas de julgamento, definidos com um semestre de antecedência ${ }^{269}$.

Feitas essas ponderações, a sistemática recursal do ordenamento jurídico pátrio, por óbvio, não se limita aos recursos de sobreposição no que concerne aos tribunais superiores, havendo outros recursos que podem ser analisados pelo STF e STJ, em especial agravos, além dos feitos de competência originária.

O intuito do recorte metodológico ora empreendido foi o de, tão somente, fincar as bases para pavimentar o estudo, que seguirá, sobre o nítido movimento em prol do incremento dos mecanismos de uniformização da jurisprudência no direito brasileiro.

E, como visto alhures, isso envolve, inexoravelmente, os conceitos de precedente e de jurisprudência, que não se confundem, em que pese se tratarem de temas análogos e quiçá complementares.

Contudo, é a partir de reiteradas decisões proferidas pelos Tribunais Superiores (geralmente em sede de julgamento dos recursos de sobreposição) que são formados os precedentes stricto sensu, permitindo a aplicação das técnicas disponíveis para tentar unificar o entendimento do tribunal em torno de determinado tema e, por conseguinte,

268 STF. Números da Repercussão Geral. Disponível [online] em http://www.stf.jus.br/portal/cms/verTexto.asp?servico=jurisprudenciaRepercussaoGeral\&pagina=numeroRep ercussao. Acesso em 14.10.2014.

${ }^{269}$ Migalhas, "STF se aproxima da terceira década...", op. cit., pp. 06-07. 
aumentar a segurança jurídica e previsibilidade para o jurisdicionado, além de reduzir os trabalhos da Corte no julgamento de feitos que versam sobre idêntica temática.

Assim é que se faz mister estudar, mais aprofundadamente, a figura do precedente no direito pátrio, tendo em mente todas as considerações tecidas sobre o tema no item 2.2.3 supra.

\subsection{A evolução do precedente judicial no direito brasileiro: rumo ao common law?}

No âmbito brasileiro, a História retrata que a atividade judicial sempre desempenhou fundamental importância, tanto no exercício da prática forense como no aperfeiçoamento dogmático dos institutos jurídicos, com grande destaque para os precedentes judiciais.

Ainda sob a égide da dominação portuguesa, a Relação do Rio de Janeiro, ao ser transformada na Casa da Suplicação para o Brasil, por força de Alvará datado de 10 de maio de 1808, passou a proferir os já mencionados assentos, só que interpretativos, possuindo a mesma eficácia que os assentos então emitidos pela Casa de Suplicação de Lisboa, contra os quais não cabia recurso; desta feita, a segurança jurídica era prestigiada ao fazer com que as sentenças desde logo transitassem em julgado ${ }^{270}$.

A partir do Regulamento n. 737 , de 1850, o Brasil passou a ter leis próprias sobre organização judiciária e processo civil, mas nessa época não havia qualquer previsão específica a respeito dos precedentes judiciais, seja para discipliná-los em face de eventuais lacunas da lei, seja, ainda, para prevenir divergência de entendimentos em casos semelhantes.

Nesse contexto, o Decreto n. $.^{\circ} 2.684 / 1875$ implantou, no ordenamento brasileiro, os assentos preexistentes, editados em Portugal e aqui, uma vez que não podíamos contar com um acervo jurisprudencial próprio, reiterando, por conseguinte, a tradição dos assentos da Casa da Suplicação do Brasil (1808).

\footnotetext{
${ }^{270}$ Segundo TuCCI e AzEvEdo narram, a Casa da Suplicação brasileira tinha por fim "guindá-la à condição de supremo tribual de justiça, para se findarem ali todos os pleitos em última instância, por maior que seja seu valor." (TUCCI, J. R. C. e; AZEVEDO, L. C., op. cit., pp. 174-175).
} 
Tal regime de assentos, com eficácia vinculante, quando aprovados por $2 / 3$ dos membros do STJ brasileiro, criado em 1824, persistiu até o advento da República, momento em que foi criado o recurso extraordinário para, como dito, preservar a autoridade e uniformidade na aplicação da Constituição e das leis federais, pelo Supremo Tribunal Federal.

A relevância dos precedentes judiciais como subsídio para a interpretação da legislação, no Brasil, é inegável. Com a instalação do STF, em 1891, ao seguir o modelo dos EUA, foi previsto o recurso extraordinário contra acórdãos de tribunais estaduais, quando houvesse divergência de interpretação de lei federal, visando, claramente, exercer "o controle nomofilático sobre a distribuição de justiça pelos órgãos jurisdicionais inferiores "271.

Ademais, na tentativa de uniformizar a interpretação e aplicação do direito pátrio, o Decreto n. $^{\circ} 16.273 / 1923$ criou o mecanismo do prejulgado, mediante o qual a decisão de uma questão controvertida, por órgãos fracionários da Corte de Apelação do então Distrito Federal, era necessariamente submetida à apreciação de todos os seus integrantes, reunidos em plenário, prática essa que, a despeito de ter sido extinta com a reforma de 1926, foi novamente prevista em 1930.

O prejulgado, como mecanismo que intentou evitar interpretações divergentes, foi acolhido tanto pelo CPC vigente à época como pelo Código Comercial do Estado de São Paulo, possuindo força obrigatória para o caso concreto, mas com caráter apenas persuasivo para os casos futuros; posteriormente, a partir da Lei 319, de 1936, tal regime foi estendido a todo o território nacional.

Segundo TuCCI, porém, a eficácia vinculante era apenas horizontal, uma vez que, caso uma das turmas contrariasse a regra jurídica antes fixada pelo tribunal pleno, era possível a interposição de recurso de revista ${ }^{272}$.

Essas considerações mostram que o prestígio e grau de persuasão do julgamento uniformizador, para a solução de litígios análogos no futuro, afiguram-se consentâneos com seu caráter ético.

\footnotetext{
${ }^{271}$ TUCCI, J. R. C. e. Precedente...cit., p. 237.

${ }^{272}$ Idem, p. 239.
} 
Uma observação mais acurada do sistema brasileiro anteriormente à promulgação da $\mathrm{CF} / 88$, em que pese comprovar que nossa tradição sempre houve por bem repudiar a adoção dos precedentes com efeitos vinculantes, retrata que excepcionalmente podia o Judiciário, mediante expressa autorização constitucional, estabelecer regras genéricas e abstratas, válidas coercitivamente para casos análogos futuros.

Com efeito, tradicionalmente a jurisprudência, como fonte subsidiária para a hermenêutica, nunca ocupou muito destaque na literatura jurídica brasileira, seja pelo perfil conservador da magistratura, seja, ainda, em virtude do sentimentalismo que assolava os tribunais pátrios $^{273}$.

Com o advento da Emenda Constitucional de 1963, porém, passou a ser possível a instituição das chamadas súmulas de jurisprudência dominante, que resultavam do julgamento da maioria absoluta dos membros que integravam a Corte e condensavam a tese jurídica em um enunciado que se tornaria precedente de uniformização de jurisprudência ${ }^{274}$.

Assim, no decorrer de 1964 foram editadas 370 súmulas pelo STF, as quais passaram a ser editadas por outros tribunais, mas não ostentavam o caráter de precedente judicial vinculante, ostentando tão-somente influência persuasiva.

O objetivo maior do Supremo, como se percebe, foi o de facilitar seus julgamentos, a partir de catalogação das decisões proferidas, sendo que a súmula constituiu, desde os primórdios, instrumento flexível, destinado a evitar o engessamento da justiça em todos os graus de jurisdição.

Interessante notar, ainda nesse contexto histórico-evolutivo, que do Anteprojeto da Lei Geral de Aplicação das Normas Jurídicas, de 1964, constou a "resolução unificadora da jurisprudência do STF”, a qual seria editada quando, por maioria absoluta, ao menos três acórdãos do Supremo tivessem sido proferidos, com caráter obrigatório, vinculando a tese aos demais tribunais e juízes inferiores. Tratava-se, pois, dos primórdios da súmula com

${ }^{273}$ MAXIMILIANO, Carlos. Hermenêutica e aplicação do direito. $6^{\text {a }}$ ed. Rio de Janeiro: Freitas Bastos, 1957, p. 230.

${ }^{274}$ TUCCI, J. R. C. e. Precedente...cit., p. 243. 
caráter vinculante, embora sua eficácia dependesse de expressa previsão constitucional ou legal.

Reavivando a antiga figura do prejulgado, o CPC de 1973 introduziu, nos arts. 476 a 479, o incidente de uniformização da jurisprudência, cuja instituição constitui dever do juiz e, ao mesmo tempo, faculdade das partes. Trata-se de incidente processual, e não de recurso, cuja finalidade é a de provocar o prévio pronunciamento do tribunal superior acerca da interpretação de determinada tese ou norma jurídica.

Reconhecida a divergência, a maioria absoluta dos membros que integram o tribunal declara a interpretação a ser observada, que se transforma em súmula e passa a constituir precedente na uniformização da jurisprudência ${ }^{275}$.

Ocorre, porém, que a prática demonstra a parca utilização do instituto pelos tribunais regionais federais e estaduais, mas no âmbito do STJ e o STF tal atividade é mais recorrente.

Dessa introdução, por força da EC n. ${ }^{\circ}$ 03/1993, resta patente que a intenção do legislador foi a de instituir um mecanismo voltado a subordinar o desfecho de demandas em curso perante os juízos inferiores à decisão do STF, ampliando sobremaneira o caminho para a adoção, no direito brasileiro, dos precedentes judiciais com eficácia vinculante. Assim, não há dúvida de que os precedentes judiciais, no STF, têm status de fonte de direito ${ }^{276}$.

Diante desse panorama, bem como da criação do STJ como a Corte máxima em matéria federal infraconstitucional, é inegável a enorme contribuição jurídica que os precedentes proferidos pelos tribunais de cúpula têm adquirido na práxis jurídica brasileira.

Tanto assim que, segundo Arruda AlviM, a expectativa é a de que tais decisões sejam paradigmáticas e que carreguem, igualmente, alto poder de convicção, justamente porque são os precedentes a serem observados e considerados pelos demais Tribunais. Na

${ }^{275}$ BRAGHITTONI, Rogério Ives. Uniformização de jurisprudência e art. $555, \S 1^{\circ}$, do Código de Processo Civil. Revista do Instituto dos Advogados de São Paulo n. ${ }^{\circ}$ 15, ano 8, jan.-jun/2005, p. 247.

${ }^{276}$ TUCCI, J. R. C. e. Precedente....cit., pp. 272-275. 
condição de precedentes, transcendem o ambiente das partes, projetando seu prestígio e autorictas para outros segmentos, não apenas jurídicos ${ }^{277}$.

Com efeito, Carlos Eduardo Stefen Elias aponta que "a mudança dos paradigmas sobre o qual se sustentam a ciência e a técnica processuais determinou forte avivamento da relevância da jurisprudência, que após as reformas foi alçada à função de requisito de admissibilidade recursal, 278 .

Mesmo porque era inimaginável, no regime original do CPC de 1973, que um recurso fosse aprioristicamente negado porque contrário à orientação jurisprudencial pacificada; o que se admitia era, no máximo, a comparação entre o conteúdo da decisão específica e aquele de outra decisão já proferida. A inovação, pois, reside na vinculação da admissibilidade de um recurso ao mérito de outro ${ }^{279}$.

Quanto à eficácia, o sistema brasileiro adotou, modernamente, um modelo misto de precedentes judiciais, porquanto convivem precedentes com eficácia meramente persuasiva, precedentes com relativa eficácia vinculante e precedentes com efetiva eficácia vinculante, conforme se extrai do entendimento de autores como JosÉ RoGÉRIO CRUZ E TuCCi $^{280}$ e Patrícia Perrone Campos Mello ${ }^{281}$. Vamos a eles:

(a) Precedentes com eficácia meramente persuasiva:

Ainda que com eficácia meramente persuasiva e de forma excepcional, há precedentes que adquirem praticamente a condição de costumes judiciários, oriundos de constantes repetições e que são aplicados racional e pacificamente, como bem indicam TuCCI e LIMONGI $^{282}$.

\footnotetext{
277 ALVIM, Arruda, op. cit., pp. 38-39.

${ }^{278}$ ELIAS, Carlos Eduardo Stefen. Os fundamentos da estrutura do sistema recursal no Código de Processo Civil de 1973 e no Projeto de novo Código de Processo Civil. In: JUNIOR, Nelson Nery; WAMBIER, Teresa Arruda Alvim (coords.). Aspectos polêmicos e atuais dos recursos cíveis e assuntos afins, v. 12. São Paulo: RT, 2011, p. 80.

${ }^{279}$ Idem, p. 80.

${ }^{280}$ TUCCI, J. R. C. e, Parâmetros...cit., p. 112.

${ }^{281}$ CAMPOS MELLO, Patrícia Perrone. Precedentes. Rio de Janeiro: Renovar, 2008, pp. 104-105.

${ }^{282}$ TUCCI, J. R. C. e, Parâmetros...cit., p. 112; FRANÇA, R. L., op. cit., p. 179.
} 
Conquanto doutrinadores mais clássicos, encabeçados por Miguel REALE ${ }^{283}$, teçam críticas à tentativa de aproximar as súmulas que são editadas pela jurisprudência brasileira à doutrina dos binding precedents dos sistemas anglo-saxões, são elas valiosos entendimentos arraigados no seio dos tribunais e que auxiliam a interpretação dos casos concretos, ainda que destituídas de força obrigatória e que não subordinem os magistrados ao conteúdo nelas disposto ${ }^{284}$.

De fato, os institutos em comento possuem particularidades bem definidas que os distinguem, mas se o que se busca, incessantemente, é um entendimento mais uniforme possível no âmbito das Cortes que devem ditar o direito, não é dado fechar os olhos para uma prática que vem se tornando cada vez mais arraigada nos tribunais pátrios, também como mecanismo de evitar decisões contraditórias e, ao mesmo tempo, reduzir o excessivo volume de trabalho.

Excepcionalmente, portanto, não é impossível que determinados precedentes adquiram verdadeiro status de preceitos gerais.

ViCENTE Greco FiLHo vai além, ao afirmar que o entendimento proferido pelo plenário no precedente judicial vincula o órgão fracionário do tribunal para o caso concreto, mas não para os futuros julgados, em relação aos quais só possui efeito persuasivo ${ }^{285}$.

\section{(b) Precedentes com relativa eficácia vinculante:}

Um exemplo claro dos precedentes que gozam de certo grau vinculativo é extraído do próprio instituto do incidente de uniformização de jurisprudência, há pouco mencionado, sendo que, uma vez reconhecida a divergência, o resultado da interpretação carreada pelo tribunal resulta na edição de uma súmula, integrando o mister uniformizante da jurisprudência.

O mais flagrante exemplo, porém, resulta das próprias súmulas, sendo certo que os precedentes sumulados "gozam de vigorosa força persuasiva" ( "binding de facto") ${ }^{286}$, que muitas vezes passa a ser o entendimento predominante.

\footnotetext{
${ }^{283}$ REALE, Miguel. Fontes e modelos do direito. São Paulo: Saraiva, 1994, p. 72.

${ }^{284}$ No mesmo sentido do aqui sustentado, cf. TUCCI, J. R. C. e, Parâmetros...cit., p. 113.

${ }^{285}$ FILHO, Vicente Greco. Direito Processual Civil brasileiro. $13^{\mathrm{a}}$ ed. São Paulo: Saraiva, 1998, p. 382.
} 
É o caso, v.g., das Súmulas 07 do STJ e 279 do STF, que vedam o reexame fáticoprobatório em sede de recurso especial e extraordinário, e cuja edição passou a representar um enorme desafogo para os Tribunais Superiores - sem adentrar o mérito do seu conteúdo.

Fato é que, hodiernamente, ainda no âmbito dos tribunais locais ou federais, o presidente do respectivo tribunal tem negado seguimento aos recursos dirigidos às Cortes Superiores invocando justamente como fundamento as referidas súmulas, porquanto as partes em tese buscam revolver fatos e provas produzidas perante instâncias inferiores. Retornar-se-á a esse tema no capítulo seguinte.

Esse é um exemplo "negativo" de aplicação dominante de uma súmula jurisprudencial, porquanto auxilia o juízo negativo de admissibilidade dos recursos, mas há inúmeros outros em que os tribunais se apoiam para dar ou negar provimento aos recursos quanto ao seu mérito.

Caminhando nesse sentido, o legislador, a partir de 1995, passou a permitir explicitamente que o relator de qualquer recurso pode ser liminarmente indeferido quando o argumento da parte recorrente confrontar súmula ou jurisprudência dominante do respectivo tribunal, do STF ou de Tribunal Superior (leia-se STJ, TST e STM). É o que consta do art. 557 do Código de Processo Civil, e não raras vezes os relatores fazem uso desse poder legal, chamado de "súmula impeditiva de recurso" 287.

Ora, tal poder é claramente superior ao dos precedentes que são apenas persuasivos, mas inferior ao das súmulas vinculantes. Não deixa de ser admirável, porém, que o direito brasileiro tenha permitido a substituição do julgamento colegiado pelo juízo monocrático como forma de, nas hipóteses citadas, prestigiar o que já fora decidido pelo próprio tribunal ou Corte superior.

Outro exemplo foi a introdução, em 2001 , do $\S 1^{\circ}$ no art. 555 do CPC, por meio do qual foi permitida outra técnica de uniformização, ao mesmo tempo assemelhada e distinta do incidente de uniformização de jurisprudência. Trata-se de uma uniformização preventiva

\footnotetext{
${ }^{286}$ TUCCI, J. R. C. e, Parâmetros...cit., p. 115.

${ }^{287}$ Vide, a esse respeito: ROSAS, Roberto. Direito sumular. $11^{\text {a }}$ ed. São Paulo: Malheiros, 2002.
} 
ou repressiva, mas interna corporis, ou seja, de divergência surgida entre câmaras ou turmas de um mesmo tribunal, de maneira que o relator do recurso (e somente ele) poderá encaminhá-lo para julgamento por órgão colegiado, em razão do interesse público que o recurso carrega ${ }^{288}$.

(c) Precedentes com eficácia vinculante:

Três são as hipóteses, atualmente, de instrumentos jurisprudenciais que possuem eficácia vinculante, quais sejam: (i) as súmulas vinculantes editadas pelo STF; (ii) as decisões proferidas em sede de controle concentrado de constitucionalidade pelo STF e pelos Tribunais de Justiça locais; e (iii) as decisões proferidas nos incidentes de demandas repetitivas.

A despeito de os institutos virem mais bem delineados e aprofundados em tópico próprio, a ideia que se deseja fincar, desde logo, é a de que as teses sumuladas não podem, jamais, tornar-se imutáveis, sob pena de representar a estagnação da jurisprudência, perigo este que, como apontado alhures, consiste na faceta negativa da tentativa, a todo custo, de introduzir mecanismos responsáveis pela uniformização coletiva quantitativa da jurisprudência.

Lapidar, neste esteio, o alerta feito por CÂNDIDo RANGEL DinAMARCo, para quem "[a estagnação da jurisprudência] não convém a sistema algum. O mais nobre dos predicados do chamado direito jurisprudencial é a sua capacidade de adaptar-se às mutações sociais e econômicas da nação, de modo a extrair dos textos constitucionais e legais a norma que no momento atenda aos reclamos axiológicos da sociedade., ${ }^{289}$

Todavia, diferentemente dos períodos históricos ingleses, em que a revisão do entendimento sedimentado por meio do precedente era praticamente um tabu, o superamento de determinada tese jurídica no direito brasileiro não engendra tantas dificuldades.

\footnotetext{
${ }^{288}$ Vide, a respeito, DINAMARCO, Cândido Rangel. A reforma da reforma, $6^{\mathrm{a}}$ ed. São Paulo: Malheiros, 2003, p. 135.

${ }^{289}$ DINAMARCO, Cândido Rangel. Súmulas vinculantes. Revista Forense n. ${ }^{\circ}$ 347, v. 95, Rio de Janeiro, 1999, p. 64.
} 
A uma, porque os precedentes com eficácia vinculante não ocorrem em volume expressivo; sua principal aplicação ocorre por meio das súmulas vinculantes, que atualmente somam 33.

A duas, porque a uniformização do entendimento jurisprudencial pátrio, a despeito de concernir a um desiderato explícito da comunidade jurídica como um todo e do legislador, está longe de ser atingida, até mesmo no seio dos Tribunais Superiores (em que há divergências de visões entre turmas de julgamento), que têm por função precípua justamente ter um entendimento unívoco a fim de permitir a pacificação da divergência entre os tribunais de instância inferior.

Ou seja, se é missão constitucional do STF e do STJ proceder à uniformização, o próprio legislador toma por premissa a intensa disparidade de posicionamento entre os tribunais regionais federais e os tribunais de justiça locais.

Desta feita, todo precedente perderá tal status, seja no common law, seja, ainda, no civil law, sempre que uma das seguintes condições for verificada: (i) ser contraditório; (ii) tornar-se ultrapassado; (iii) tornar-se obsoleto em virtude de mutações jurídicas; ou (iv) mostrar-se equivocado ${ }^{290}$.

O desenvolvimento do processo civil brasileiro, destarte, mostra seu direcionamento em prol da utilização dos precedentes, tal como ocorre no common law, o que é saudado por muitos juristas pátrios, em que pese a existência de algumas críticas quando são comparados os métodos lá praticados com os que aqui foram adotados com relação à aplicação das decisões paradigma ${ }^{291}$.

\footnotetext{
${ }^{290}$ CAMPOS MELLO, P. P., op. cit., p. 41.

291 "Em verdade, tanto o mecanismo de comparação entre decisão recorrida e decisões-paradigma em vigor quanto o concebido para o novo Código de Processo Civil para o sistema recursal pátrio são diferentes e até mesmo contrários à prática da utilização de precedentes dos países de common law. Para esse ramo do direito, os precedentes fornecem a ratio decidendi, ou seja, o modo pelo qual a solução deve ser construída, a fim de que a aproximação entre os pressupostos das duas situações, entre os dois conflitos, permita que a solução pretérita seja utilizada para o conflito presente. O sistema brasileiro, ao contrário, cerceia justamente o diálogo pela imposição, não da ratio decidendi, que demandaria a participação dos interessados (partes e juiz) para a verificação das coincidências entre os pressupostos do caso paradigma e do caso a decidir, mas da decisão pronta e acabada”. (ELIAS, C. E. S., op. cit., p. 94).
} 
Nesse contexto, vejamos, singelamente, quais foram os principais instrumentos que, uma vez positivados no ordenamento jurídico brasileiro, viabilizaram essa mudança significativa de viés.

\subsection{Os mecanismos de valorização e uniformização da jurisprudência no atual direito brasileiro}

Como destacado anteriormente, a "reforma do Poder Judiciário", consubstanciada na EC n. ${ }^{\circ} 45 / 04$, trouxe várias inovações ao sistema processual (inclusive constitucional), com o principal escopo de trazer maior celeridade à tramitação dos processos - e, por conseguinte, agilidade na prestação jurisdicional.

De igual modo, nesta e em outras "minirreformas" sofridas pelo atual CPC, observa-se o nítido intuito do legislador de privilegiar a jurisprudência, a partir da institucionalização e aprimoramento de técnicas coletivas de sua uniformização.

Em sintonia com o desiderato do preceito constitucional contido no art. 5. ${ }^{\circ}$, LXXVIII, que sustenta constitucionalmente a nova onda de reformas da legislação processual civil, os recursos de sobreposição ganharam uma nova sistemática legislativa que possibilita, em tese, uma maior celeridade em seu procedimento de julgamento.

Isso porque, na jurisdição contemporânea, busca-se, cada vez mais, conferir aos tribunais superiores e seus respectivos recursos de sobreposição caráter excepcional, ou seja, que visem à análise de causas que tenham repercussão social e/ou econômica, principalmente no sentido de que tais Cortes não devem funcionar como um terceiro grau de jurisdição.

A compreensão dessa nova sistemática procedimental parte de algumas premissas básicas, tais como a existência de características singulares aos dois recursos excepcionais, apontadas no tópico antecedente.

Passa-se, destarte, à análise dos principais institutos que representam, em maior ou menor grau, a tentativa de proceder à uniformização da jurisprudência, elevando-a praticamente a uma missão legal (e quiçá constitucional). 
Muitos desses institutos precederam a citada EC n. ${ }^{\circ} 45 / 04$, outros deles vieram carregados no seu bojo, mas fato é que todos se enquadram no que classificamos como "caminhar" em direção ao common law, no sentido da valorização do direito jurisprudencial.

\subsubsection{Repercussão geral}

Uma das principais novidades advindas no seio da EC n. ${ }^{\circ}$ 45/04, que já foi brevemente mencionada adrede nesta Dissertação, foi a introdução do $\S 3^{\circ}$ no art. 102 da CF, exigindo que o recorrente demonstre a repercussão geral das questões constitucionais debatidas no caso, alçada verdadeiramente à condição de requisito de admissibilidade do recurso extraordinário.

No site do próprio STF encontramos a seguinte descrição sobre o objetivo do instituto: “(...) possibilitar que o Supremo Tribunal Federal selecione os Recursos Extraordinários que irá analisar, de acordo com critérios de relevância jurídica, política, social ou econômica. $O$ uso desse filtro recursal resulta numa diminuição do número de processos encaminhados à Suprema Corte”.

O sítio do Pretório Excelso também dispõe minuciosamente sobre o procedimento para seu reconhecimento, destacando que a análise da repercussão se dá a contrario sensu, ou seja, são necessários 8 votos dos Ministros para que seja recusada a análise do recurso ${ }^{292}$.

Tal preceito surgiu, claramente, da necessidade de se criar um filtro para os recursos de natureza extraordinária, funcionando como verdadeiro mecanismo de contenção de matéria; todavia, não se trata de novidade no sistema constitucional pátrio, posto que a $\mathrm{CF}$ de 1967 já falava na "relevância da questão federal".

Inicialmente, portanto, discutiu-se se a repercussão geral seria a reinserção da arguição de relevância - extinta com o advento da $\mathrm{CF} / 88$-, mas tal afirmação não se mostra verdadeira. A arguição de relevância tinha por escopo permitir o julgamento do recurso extraordinário em hipóteses em que ele não seria analisado, já a repercussão geral possui

292 Supremo Tribunal Federal. Definição de repercussão geral. Disponível [online] em http://www.stf.jus.br/portal/glossario/verVerbete.asp?letra=R\&id=451. Acesso em 12.10.2013. 
finalidade totalmente contrária, qual seja, excluir as hipóteses de admissibilidade dos recursos extraordinários quando ausente a repercussão geral ${ }^{293}$.

A despeito do escopo antagônico, são dois conceitos análogos, sendo certo que haverá repercussão geral quando a questão, "pelos reflexos na ordem jurídica, e considerados os aspectos morais, econômicos, políticos ou sociais, exigir a apreciação do recurso extraordinário pelo Tribunal”, exatamente como constava do revogado art. $327, \S 1^{\circ}$, do RISTF, ou seja, exige-se que a questão constitucional, para que o recurso extraordinário seja conhecido, seja qualificada ${ }^{294}$.

De forma semelhante, a instituição da relevância envolvia a outorga de um poder político ao tribunal para apreciar as causas que tinham importância social, econômica, institucional ou jurídica ${ }^{295}$.

O que se viu, pois, foi a inserção de um novo requisito extrínseco de admissibilidade para o recurso extraordinário, sendo que sua ausência é defeito formal que enseja inadmissibilidade do recurso, trazendo grandes consequências para as instâncias inferiores, uma vez que, reconhecida a repercussão geral, os processos que versam sobre a mesma matéria ficam suspensos até que o tribunal superior profira decisão sobre ela. Além disso, uma vez negada a existência de repercussão geral, a decisão será aplicada a todos os processos com matéria idêntica, que serão indeferidos liminarmente.

Para viabilizar o recurso extraordinário, portanto, deve a "repercussão" da questão constitucional ser geral e ter uma relevância considerável, o que não significa dizer que deva ela ser, necessariamente, de âmbito nacional, podendo ser regional e até mesmo local, contanto que possua importância constitucional; de outro lado, o que não se viabiliza mais é a questão que, a despeito do seu fundamento constitucional, fica restrita à esfera privada do recorrente.

Trata-se, com efeito, de instituto inspirado no writ of certiorari do direito norte-americano, cuja aprovação exige a "rule of four" (aprovação por quatro Justices, em meio a um quórum de seis presentes), em que pese o fato de VALENTina Pinto considerá-lo um filtro

\footnotetext{
293 ALVIM, A., op. cit., p. 40.

${ }^{294}$ MEDINA, J. M. G., Prequestionamento...cit., p. 121.

295 ALVIM, A., op. cit., p. 42.
} 
menos efetivo do que aquele existente no direito estrangeiro, eis que o nível de discricionariedade dos ministros brasileiros é mais limitado ${ }^{296}$.

Analogamente aos recursos cíveis, no âmbito da Justiça do Trabalho há o requisito da transcendência dos recursos de revista, que deve ser demonstrado perante o Tribunal Superior do Trabalho, tal como exige o artigo 896-A da CLT, introduzido pela Medida Provisória n. ${ }^{\circ}$ 2.226/2001. A transcendência é, também, um requisito de admissibilidade do recurso de revista que, à semelhança da repercussão geral, impõe a necessidade de demonstrar que o caso possui "transcendência com relação aos reflexos gerais de natureza econômica, política, social ou jurídica".

\subsubsection{Repercussão geral nos recursos especiais: a PEC 209/2012}

Atualmente, está em voga a discussão acerca da extensão do requisito da repercussão geral aos recursos especiais, por meio da Proposta de Emenda Constitucional n. 209/2012 (“PEC 209/2012”, já aprovada pela Comissão de Constituição e Justiça da Câmara dos Deputados), medida esta que é defendida há longa data por diversos juristas, como ARruda Alvim ${ }^{297}$.

Na essência, os $\S \S 1^{\circ}$ a $7^{\circ}$ que se pretende incluir no art. 105 da Constituição seguem o modelo da repercussão geral exigida para os recursos extraordinários, ou seja, o recorrente deve demonstrar a relevância da questão federal arguida, ou seja, a repercussão, seja para fins econômicos, sociais, jurídicos ou políticas, deve ultrapassar os interesses das partes envolvidas na demanda.

Outra novidade a fim de limitar o acesso ao STJ por meio dos recursos especiais é a criação de requisito de admissibilidade atrelado ao valor da controvérsia, porquanto o projeto fala que, nas causas que envolvam valor inferior a 200 (duzentos) salários mínimos - aproximadamente $\mathrm{R} \$ 160$ mil, não poderá ser interposto recurso especial.

\footnotetext{
${ }^{296}$ PINTO, V. M. F., op. cit., p. 115.

297 “Ainda que entre nós dependa de reforma constitucional, parece-nos que o caminho adequado seria o restabelecimento da arqguição de relevância, para as finalidades colimadas pela atividade judicante do STJ”. ALVIM, Arruda. O antigo recurso extraordinário e o recurso especial (na Constituição Federal de 1988). In: TEIXEIRA, Sálvio de Figueiredo (coord.). Recursos no Superior Tribunal de Justiça, São Paulo: Saraiva, 1991, p. 154.
} 
Recentemente, a Comissão Especial criada para a apreciação da PEC 209/2012 também aprovou a proposta do substitutivo apresentado pelo relator, Deputado Sandro Mabel, para, além de incluir os $\S \S 1^{\circ}$ a $7^{\circ}$ no art. 105 da Constituição disciplinando a repercussão geral para os recursos especiais, acrescentar o art. 105-A à Carta Maior, regulando a edição de súmulas impeditivas de recursos também pelo STJ, mediante a aprovação de quatro quintos dos membros do respectivo órgão fracionário do Tribunal, quando houver reiteradas decisões sobre uma mesma matéria.

Dada a importância e atualidade do debate, vejamos as redações propostas:

"Art. 105.

$\$ 1^{\circ}$ O Superior Tribunal de Justiça não admitirá recurso especial sem que o recorrente demonstre a relevância das questões de direito federal infraconstitucional discutidas no caso.

$\$ 2^{\circ}$ A rejeição da relevância da questão federal depende da manifestação de quatro quintos dos membros do órgão competente, devendo ser apreciada em até noventa dias.

$\$ 3^{\circ}$ Acolhida a relevância, o recurso especial será submetido a julgamento em até doze meses, Superado este prazo, os recursos sobrestados na origem deverão ser encaminhados ao Superior Tribunal de Justiça para julgamento.

$\$ 4^{o}$ Serão tidas como relevantes as questões de direito federal que tenham repercussão econômica, política, social ou jurídica e que ultrapassem os interesses subjetivos da causa.

$\$ 5^{\circ}$ Incluem-se entre as questões consideradas relevantes a divergência da decisão recorrida com súmula do Superior Tribunal de Justiça.

$\S 6^{\circ}$ Não cabe recurso especial nas causas com valor inferior a 200 (duzentos) salários mínimos, salvo se houver divergência entre a decisão recorrida e súmula do Superior Tribunal de Justiça.

$\$ 7^{\circ}$ Para demonstração da relevância das questões de direito federal infraconstitucional, aplicamse as mesmas disposições legais referentes à demonstração de repercussão geral para admissibilidade do recurso extraordinário.

Art. 105-A. O Superior Tribunal de Justiça poderá, de ofício ou por provocação, mediante decisão de quatro quintos dos membros do órgão fracionário competente, após reiteradas decisões sobre a matéria, aprovar súmula que, a partir de sua publicação, constituir-se-á em impedimento à interposição de quaisquer recursos contra a decisão que a houver aplicado; bem como proceder à revisão ou cancelamento.

$\$ 1^{\circ}$ A súmula terá por objetivo a validade, a interpretação e a eficácia de normas determinadas, acerca das quais haja controvérsia atual entre órgãos judiciários ou entre esses e a administração pública, que acarrete grave insegurança jurídica e relevante multiplicação de processos sobre questão idêntica.

$\$ 2^{\circ}$ A aprovação, revisão ou cancelamento de súmula poderá ser provocada originariamente perante o Superior Tribunal de Justiça por aqueles que podem propor a ação direta de inconstitucionalidade.

$\$ 3^{\circ}$ São insuscetíveis de recurso e de quaisquer meios de impugnação e incidentes as decisões judiciais, em qualquer instância, que deem a tratado ou lei federal a interpretação determinada pela súmula impeditiva de recurso".

À primeira vista, parece-nos, no esteio do pensamento de diversos processualistas pátrios, ser salutar a possível aprovação do requisito da repercussão geral também para os recursos 
especiais, na medida em que tal requisito contribuirá para filtrar, efetivamente, as questões que ofendam o direito federal e mereçam ser apreciadas pelo STJ.

Por outro lado, afigura-se preocupante a proposta no que tange ao requisito de admissibilidade do recurso ser vinculado ao valor da causa. Isso porque, muitas vezes, as demandas têm valores inestimáveis para fins econômicos, e mesmo assim possuem enorme relevância para a sociedade, seja econômica, política, jurídica ou social, o que atenderia ao novo comando.

Parece perigoso, para fins de segurança jurídica e mesmo em face da garantia constitucional do acesso à Justiça, estabelecer esse limite simplório, desconsiderando-se a natureza e as peculiaridades da demanda, admitindo-se, como única exceção, a interposição do recurso em demandas cujo acórdão contrarie súmula do STJ, tal como o faz o $\$ 6^{\circ}$ da redação em vias de aprovação.

A nosso ver, caberia aos tribunais a quo o exame, ainda que perfunctório, da relevância como já ocorre na prática - acrescido da análise à luz dos valores envolvidos na controvérsia, de modo que tal apreciação poderia segregar as demandas que não contenham conteúdo econômico direto e, mesmo assim, devem ser analisados pela Corte Superior.

\subsubsection{Súmula vinculante}

A súmula vinculante também é fruto da $\mathrm{EC} \mathrm{n.}{ }^{\circ} 45 / 04$, assim dispondo o art. 103-A da CF/88: "o Supremo Tribunal Federal poderá, de ofício ou por provocação, mediante decisão de dois terços dos seus membros, após reiteradas decisões sobre matéria constitucional, aprovar súmula que, a partir de sua publicação na imprensa oficial, terá efeito vinculante em relação aos demais órgãos do Poder Judiciário e à administração pública direta e indireta, nas esferas federal, estadual e municipal, bem como proceder à sua revisão ou cancelamento, na forma estabelecida em lei".

A súmula vinculante tem como objeto matéria constitucional com aplicação reiterada de jurisprudência, ou pacificação do entendimento no âmbito do STF, em relação a matéria que ainda seja controversa entre os órgãos do Judiciário, ou entre estes e a Administração 
Pública. Uma vez aprovada, tem aplicação imediata em todos os processos pendentes, em qualquer instância.

Logo no início da vigência das mudanças carreadas pela EC n. ${ }^{\circ}$ 45/04, a maior parte dos entendimentos contrários às súmulas com efeito vinculante sustentavam que ela violaria os princípios do juiz natural e do livre convencimento, bem como temiam que sua aplicação trouxesse o engessamento da jurisprudência, tendo em vista a pretensão da súmula atuar com força de lei.

Os defensores da medida, contudo, apontaram que ela garante maior segurança jurídica, uma vez que os casos idênticos não teriam julgamentos divergentes, bem como atenderiam à razoável duração do processo. O juiz, se verificar que o caso concreto diverge do caso de aplicação da súmula, deve afastar sua aplicação; além disso, há a possibilidade de o STF rever seu posicionamento, editando e alterando o conteúdo da súmula, portanto foram devidamente repelidas, a nosso ver, todas as preocupações acima apontadas.

De todo modo, a despeito do debate intrínseco à sua utilidade e/ou conformidade das súmulas vinculantes ao ordenamento brasileiro, trata-se de mecanismo "importado" do sistema da common law, como visto anteriormente, que, na prática, trouxe muitos benefícios para a redução da carga recursal dos tribunais superiores, principalmente quanto à vinculação da administração pública. Isso porque das 85 (oitenta e cinco) partes que são responsáveis por concentrar mais de $75 \%$ dos processos do STF, a maior parcela é oriunda do Executivo Federal, e delas três figuram em mais de $50 \%$ do total dos recursos (Caixa Econômica Federal - 18,87\%, União - 16,48\% e INSS - 14,87\% $)^{298}$.

Com efeito, o grande desafio, de início, era evitar que a súmula vinculante gerasse a imutabilidade da jurisprudência dominante do próprio STF, de modo que, à semelhança do direito inglês e norte-americano, fosse possível que o tribunal revisse seu posicionamento e revogasse ou modificasse o teor da súmula.

Além de tal previsão de revisão e/ou cancelamento ter vindo expressamente positivada na Lei n. ${ }^{\circ}$ 11.417/2006, que regulamentou o art. 103-A da CF, já foi verificada, na prática,

${ }^{298}$ FALCÃO, J.; CERDEIRA, P. de C.; ARGUELHES, D. W., op. cit., p. 68. 
alteração de conteúdo de algumas súmulas vinculantes, casos das que trataram do nepotismo e do ISS.

\subsubsection{Recursos repetitivos}

Se o tribunal recorrido (seja ele estadual ou federal) verificar multiplicidade de recursos extraordinários com idêntica fundamentação de direito (art. 543-B do CPC), alguns recursos representativos da controvérsia serão encaminhados ao STF, ficando os demais sobrestados.

A partir de então, surgem três possibilidades: (i) se negada a repercussão geral, os recursos sobrestados serão automaticamente inadmitidos; (ii) julgado o mérito dos recursos encaminhados, os sobrestados serão apreciados na origem - sendo considerados prejudicados no caso de a tese do recurso ser divergente daquela decidia pelo STF. Há, também, a possibilidade do juízo de retratação da decisão recorrida, nos casos em que a decisão contrariar tese fixada pelo STF. (iii) Somente se mantida a decisão que tenha tese contrária àquela decidida pelo Pretório Excelso nos recursos representativos, é que a Corte poderá cassar ou reformar liminarmente aquela decisão.

Quanto ao julgamento de causas repetitivas no âmbito do STJ (art. 543-C do CPC), o tribunal de origem deverá, igualmente, selecionar alguns recursos representativos da controvérsia encaminhando-os ao STJ, sobrestando os demais. Após o julgamento dos recursos encaminhados, abrem-se as seguintes possibilidades: se a decisão recorrida estiver em conformidade com a interpretação do STJ, os recursos sobrestados terão seguimento denegado. O tribunal de origem poderá exercer o juízo de retratação caso a decisão recorrida contrarie a do STJ.

Cabe ainda ressaltar, por derradeiro, a tramitação da chamada "PEC dos Recursos" (PEC

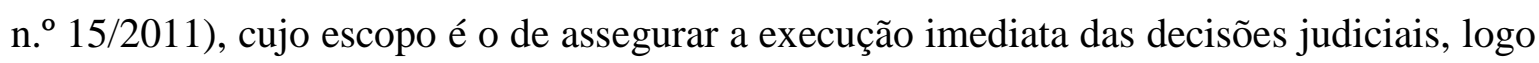
após o pronunciamento pelos tribunais de segunda instância, garantindo, assim, maior agilidade à prestação jurisdicional, eis que, segundo o ex- Ministro Cezar Peluso, acarretaria a redução de dois terços no tempo médio de tramitação. 
Ademais, os defensores da medida sustentam que, se aprovada, ela evitará que se interponha recurso com finalidade meramente protelatória, de modo que os recursos extraordinário e especial funcionariam de forma semelhante a uma ação rescisória, porquanto sua interposição não obstaria o trânsito em julgado dos acórdãos recorridos ${ }^{299}$.

\subsubsection{A súmula impeditiva de recursos}

Há que se mencionar, ainda, as chamadas súmulas impeditivas de recursos, tidas por mais brandas dos que as súmulas vinculantes, mas que são, na verdade, as duas faces da mesma moeda, uma vez que, ao editar súmula que defina determinado entendimento, o que se quer é impedir que sobre uma mesma questão jurídica advenha decisão distinta pelo juízo inferior, portanto não haveria sentido em se admitir recursos interpostos contra decisões que se fundamentam exatamente nessas súmulas.

Portanto, a regra do parágrafo primeiro do art. 518 do CPC, que recebeu essa denominação de "súmula impeditiva de recursos", constitui parte integrante do juízo de admissibilidade dos recursos cíveis, porquanto o recurso deverá ser interposto contra a decisão que não tenha como fundamento súmula do STJ ou do STF, aplicando-se para recursos outros que não apenas o de apelação, à exceção do recurso especial e do extraordinário.

\subsubsection{Decisões proferidas em sede de controle concentrado de constitucionalidade}

O Brasil, desde a República, adotou o modelo difuso de controle de constitucionalidade, mais uma inspiração tipicamente norte-americana. Além da competência atribuída a qualquer órgão do Poder Judiciário para conhecer, incidenter tantum, a inconstitucionalidade apontada, a CF de 1934 passou a permitir também o controle concentrado.

Com a EC n. ${ }^{\circ} 45 / 04$, mudanças foram introduzidas nesse tema. Exemplificativamente, duas delas foram: (i) a unificação dos legitimados ativos para a propositura tanto da ação direta de inconstitucionalidade como da ação direta de constitucionalidade; e (ii) a eficácia erga

${ }^{299}$ Supremo Tribunal Federal, "PEC dos Recursos" é apresentada pelo presidente do STF e estará no III $\begin{array}{llll}\text { Pacto } & \text { Republicano, Disponível } & \text { [online] } & \text { em }\end{array}$ http://www.stf.jus.br/portal/cms/verNoticiaDetalhe.asp?idConteudo=174751， 21.03.2011. Acesso em 14.10.2014. 
omnes e vinculante conferida a todas as decisões definitivas de mérito, proferidas em sede de ações declaratórias de constitucionalidade de lei ou ato normativo federal, atribuída pelo $\S 2^{\circ}$ do art. 102 da CF.

Observa-se, então, que além das ações diretas de inconstitucionalidade, as ações diretas de constitucionalidade também têm eficácia vinculante, o que demonstra o enorme espectro de alcance de tais decisões, que inegavelmente carregam um imenso peso político.

De forma semelhante, também há previsão atribuindo eficácia vinculante às decisões proferidas nas arguições de descumprimento de preceito fundamental, ex vi da Lei n. ${ }^{\circ}$ 9.882/99. Daí porque a doutrina costuma falar que os precentes judiciais do STF possuem verdadeiro caráter de fonte de direito ${ }^{300}$.

$$
* * * * *
$$

Sedimentadas as premissas responsáveis pela caracterização, no direito brasileiro, da intensa valorização dos precedentes como forma de fortificar o direito jurisprudencial, é preciso apontar para outra faceta, desta feita negativa, que é umbilicalmente atrelada aos recursos de sobreposição e aos mecanismos implementados nos últimos anos para desafogar nossos tribunais superiores, que é a jurisprudência defensiva.

${ }^{300}$ TUCCI, J. R. C. e, Parâmetros...cit., p. 122. 


\section{A JURISPRUDÊNCIA DEFENSIVA}

\subsection{Aspectos gerais e conceito}

Considerando-se as premissas acima assentadas, cumpre agora apontar - e diferenciar - o que a doutrina entende por "jurisprudência defensiva". Há, inclusive, quem a diferencie da “jurisprudência defensiva de segunda geração" 301 , sendo certo que a presente reflexão também levará em consideração esse conceito.

Nesse contexto, é cediço que o volume de processos que assoberba os tribunais superiores, com enfoque maior no STF, "obscureceu a avaliação objetiva (...) no seu aspecto decisivo - na institucionalização e preservação do Estado democrático de direito. „302

Há, destarte, um descompasso entre a estrutura dos tribunais e suas funções institucionais/constitucionais, descompasso este que deve ser combatido tanto em sua vertente externa como interna.

No plano externo, como salientado alhures, as tentativas se deram por intermédio de mudanças legislativas, de tal maneira a racionalizar o trabalho do STF, motivo pelo qual houve diversas tentativas para atingir tal escopo, seja de maneira direta ou indireta.

No que tange ao plano interno, tema que ora se mostra mais relevante dado o escopo de análise da chamada jurisprudência defensiva, as medidas adotadas, quando estudadas conjuntamente, indicam que o STF e o STJ têm firmado interpretação restritiva das hipóteses de cabimento dos recursos e ações originárias de sua competência.

Tal interpretação, frise-se, derivou, historicamente, do exame tanto da letra da Carta Magna como da legislação infraconstitucional, e se mostrou, desde então, "meio válido $e$ necessário de defesa das funções precípuas do STF, dispensando-se o exame daquilo que não se mostrasse verdadeiramente apto a ser enfrentado pela Corte Constitucional." 303

\footnotetext{
${ }^{301}$ TEDESCO, Paulo Camargo. Jurisprudência defensiva de segunda geração. Revista de Processo n. ${ }^{\circ}$ 182, ano 35, abril/2010, p. 260.

${ }^{302}$ ASSIS, A. de, op. cit., p. 692.

${ }^{303}$ TEDESCO, P. C., op. cit., p. 262.
} 
Por oportuno, a este respeito Teresa Arruda Alvim WAmbier esclarece que essas “'restrições' (...) dizem respeito, na grande maioria das vezes, a regras que decorrem naturalmente da função que [os recursos de sobreposição] exercem no ordenamento ${ }^{\text {,304 }}$.

Entretanto, é preciso atentar, cuidadosamente, para a restrição às hipóteses de cabimento e, consequentemente, de acesso aos tribunais superiores, porquanto nem sempre o intuito restritivo decorre de interpretação razoável das normas jurídicas, sendo certo, invocando as lições da doutrinadora acima referida, que "há casos em que o excesso de regras em torno da admissibilidade desses recursos leva a contrassensos ${ }^{, 305}$.

Nesta senda, os desvios que existem são fruto, essencialmente, de dois fatores principais apontados pela doutrina processual: (i) existência de uma série de regras relativas ao cabimento dos recursos que leva, muitas vezes, a restrições sem fundamento dogmático; e (ii) o objetivo desmedido de redução da excessiva carga de trabalho das cortes superiores.

Essa preocupação é refletida nos escritos de um sem-número de juristas, sendo um deles Carlos Alberto Alvaro de Oliveira. Para ele, o Poder Judiciário brasileiro, cada vez mais premido pelo aumento geométrico dos casos que chegam ao sistema, teve uma reação que, às vezes, é dotada de uma efetividade perniciosa, que leva ao formalismo excessivo e não valorativo, privilegiando tão somente o desempenho numérico e estatístico ${ }^{306}$.

A esses excessos costuma-se denominar de "jurisprudência defensiva", representando a tentativa de os tribunais superiores brecarem, a todo custo, os recursos excepcionais, mediante a deturpação de entendimentos jurisprudenciais legítimos ${ }^{307}$, evitando que efetivamente cheguem para sua apreciação e julgamento ${ }^{308}$. A alteração das decisões dos tribunais estaduais e federais, assim, passou a ocorrer apenas em casos excepcionais, como aponta ATHENIENSE ${ }^{309}$.

\footnotetext{
${ }^{304}$ WAMBIER, Teresa Arruda Alvim. Recurso especial, recurso extraordinário e ação rescisória. $2^{\mathrm{a}}$ ed. São Paulo: RT, 2008, p. 267.

305 Idem, p. 268.

${ }^{306}$ OLIVEIRA, Carlos Alberto Alvaro de. Do formalismo no processo civil. $4^{\mathrm{a}}$ ed. São Paulo: Saraiva, 2010, p. 13.

${ }^{307}$ FARINA, F. M. Q., op. cit., p. 130.

${ }^{308}$ FARIA, Márcio Carvalho. O novo Código de Processo Civil vs. a jurisprudência defensiva. Revista de Processo n. ${ }^{\circ} 210$, ano 37, ago./2012, p. 265.

309 "A chamada 'jurisprudência defensiva do STJ'está voltada no sentido de tornar a cada dia mais difícil o acesso àquela Corte, como se as decisões dos Tribunais estadual e federal atendessem satisfatoriamente o que a lei prescreve, só comportando alterações em casos excepcionais." (ATHENIENSE, Aristóteles. A
} 
Acaba-se por impedir - ou ao menos dificultar - o acesso à ordem jurídica justa e a própria força normativa do direito, por meio da criação de uma barreira procedimental ${ }^{310}$, sendo as exigências apontadas como desarrazoadas e ilegítimas ${ }^{311}$. E pior: a imposição de tais restrições acaba, muitas vezes, não atingindo sua finalidade essencial, que é reduzir o volume de processos.

O apego ao formalismo exacerbado, destarte, mostra claramente que se está a estabelecer o que BARbosa Moreira chamou de "restrições ilegítimas" ao conhecimento dos recursos: "negar conhecimento a um recurso é atitude correta - e altamente recomendável - toda vez que esteja clara a ausência de qualquer dos requisitos de admissibilidade. Não devem os tribunais, contudo, exagerar na dose; por exemplo, arvorando em motivos de não conhecimento de circunstâncias de que o texto legal não cogita, nem mesmo implicitamente, agravando sem razão consistente exigências por ele feitas, ou apressandose a interpretar em desfavor do recorrer dúvidas suscetíveis de suprimento". 312

Por oportuno, não é demais lembrar que traços deste conceito podem ser extraídos antes mesmo da promulgação da CF/88 e, portanto, da criação do STJ, que, como visto alhures, consistiu no desmembramento do STF como tentativa de desafogá-lo. É o que verbera DINAMARCo, ao citar o restritivo sistema regimental, até então vigente, de admissibilidade dos recursos extraordinários, além dos “pesados óbices postos por via pretoriana, como o da razoabilidade da interpretação da lei federal",313.

O reconhecimento da importância do tema chegou até mesmo ao corpo de ministros dos tribunais superiores, tanto assim que o ex-Ministro Humberto Gomes de Barros, do STJ, costuma ser apontado como o "autor intelectual" da expressão "jurisprudência defensiva".

Com efeito, o Ministro chegou a falar, nos idos de 2008, em "desobstruir a brigada protetora" que se formou na jurisprudência pátria, tanto assim que, em seu discurso de

jurisprudência defensiva do STJ e sua inconveniência. In: SILVA, José Anchieta (org.). O novo processo civil. São Paulo: Lex Editora, 2012, p. 80).

310 FARINA, Fernanda Mercier Querido. Jurisprudência defensiva e a função dos Tribunais Superiores. Revista de Processo n. ${ }^{\circ}$ 209, ano 37, jul./2012, p. 106.

${ }^{311}$ CIUFFO, Diogo Carneiro. Os requisitos de admissibilidade dos recursos especial e extraordinário e a sua ilegítima utilização como filtros recursais. Revista de Processo n. ${ }^{\circ}$ 160, São Paulo: RT, 2008, pp. 205-232.

${ }^{312}$ BARBOSA MOREIRA, José Carlos. Restrições ilegítimas ao conhecimento dos recursos. In: Temas de Direito Processual. 9a série. São Paulo: Saraiva, 2007, p. 270.

${ }^{313}$ DINAMARCO, C. R, Superior Tribunal de Justiça...cit., p. 14. 
posse na presidência do STJ, mencionou a criação de "entraves e pretextos para impedir a chegada e o conhecimento que lhes são dirigidos [aos tribunais superiores] ${ }^{, 314}$.

Assim é que tem sido formada orientação jurisprudencial tendente a estreitar muito significativamente as hipóteses em que estaria aberta a competência do STF, e do STJ, à nova ordem dos recursos extraordinário e especial (a partir das mudanças positivadas por meio da EC n. ${ }^{\circ}$ 45/04), movimento esse que, ainda incipiente, em muito se assemelha ao de anos atrás, caracterizado pelas orientações que originaram a alcunha de jurisprudência defensiva clássica ${ }^{315}$.

Justamente por isso, "acredita-se que se está diante de verdadeiro arredamento dos excessos identificados na concepção tradicional do recurso extraordinário a essa nova ordem do recurso, razão pela qual a recente formação de orientações bastante restritivas pode ser encarada como a gênese de uma jurisprudência defensiva 'de segunda geração'. ,316

Nesse contexto, Teresa Arruda Alvim Wambier, ao interpretar o sistema atual, apontou para os contrassensos que decorrem das regras atuais sobre a admissibilidade dos recursos de sobreposição, levando a um paradoxo, em que o STF acaba por abdicar de examinar questão relevante, inclusive para fins da Constituição, apenas porque a argumentação do recorrente passa pela ofensa à lei ordinária, o que não deveria ocorrer ${ }^{317}$.

\footnotetext{
${ }^{314}$ Superior Tribunal de Justiça. Discurso de posse do Ministro Humberto Gomes de Barros. 07.04.2008. Disponível [online] http://bdjur.stj.gov.br/dspace/bitstream/2011/16933/1/Discurso_Posse_Gomes+de+Barros.pdf. Acesso em 11.04.2014.

${ }^{315}$ TEDESCO, P.C., op. cit., p. 264.

${ }^{316}$ Idem, p. 264.

317 "Há casos em que o excesso de regras em torno da admissibilidade desses recursos (excepcionais) leva a contra-sensos. Exemplo disso é a regra no sentido de que ao STF só cabe conhecer de "ofensa direta" à Constituição Federal. Isto significa dizer que, se para demonstrar que houve ofensa à Constituição Federal, a argumentação da recorrente tem necessariamente de passar pela lei ordinária (que, v.g., repete o princípio constante na Constituição) e porque se estaria diante de ofensa "indireta" à Constituição que, por isso, não deveria ser examinada pela via do recurso extraordinário. Esta regra, a nosso entender, leva a um paradoxo: a Constituição consagra certo princípio e se, pela relevância, a lei ordinária repete, por isso, o tribunal, cuja função é a de zelar pelo respeito à Constituição, abdica de examinar a questão". (WAMBIER, Teresa Arruda Alvim. Controle das deciões judiciais por meio dos recursos de estrito direito e ação rescisória: o que é uma decisão contrária à lei?. São Paulo: Revista dos Tribunais, 2001, p. 169).
} 
Em igual sentido discorre CASSio SCARPInella BUENO, para quem não existe razão para a restritividade da jurisprudência do STF quanto à ofensa direta ou indireta à Constituição, afinal o sistema atual já consagra um filtro legítimo de restrição desses recursos ${ }^{318}$.

Em linhas gerais, destarte, afigura-se extremamente complexa a hodierna interposição de recursos de sobreposição pelos causídicos. Como ilustra Rodolfo de CAMARgo MANCUSO, eles são obrigados a laborar simultaneamente com vários textos normativos, a saber: (i) a CF, para saber se a fattispecie se amolda às hipóteses dos arts. 102, III, ou 105, III; (ii) o CPC, que dita o rito de processamento dos recursos, especialmente nos arts. 541 a 545 e 557; (iii) o Regimento Interno do STJ e STF, bem assim as normas por eles expedidas (v.g. resoluções); e (iv) os precedentes, as súmulas e as súmulas vinculantes ${ }^{319}$.

Diante desse panorama, vejamos quais são as reiteradas situações, elencadas pela doutrina, que se destinam a filtrar a quantidade de recursos que efetivamente chegam ao STJ e STF para serem julgados, sem suporte legal ou constitucional, e compõem a sobredita jurisprudência defensiva.

\subsection{Principais hipóteses}

\subsubsection{Súmulas 07 do STJ e 279 do STF: a vedação ao reexame de fatos e provas}

O STJ e o STF editaram as referidas súmulas, conforme mencionado anteriormente, a fim de vedar a análise do mérito dos recursos que desejem revolver questões fático-probatórias em grau superior de jurisdição.

É imperioso voltar, pois, ao debate entre como segregar questões de fato e de direito. Não é uma tarefa fácil, mesmo para a doutrina, como bem aponta TERESA WAMBIER, que fala

\footnotetext{
318 “A jurisprudência do Supremo Tribunal Federal, contudo, sempre foi e continua a ser bastante restritiva a este respeito, exigindo que a inconstitucionalidade que desafia o recurso extraordinário com fundamento na letra " $a$ " seja direta, e não indireta, oblíqua. O entendimento poderia até querer justificar a necessidade de redução do número de recursos extraordinários em trâmite perante aquela Corte. No sistema atual, em que há um legítimo filtro de contenção daqueles recursos, não há razão para distinguir aquelas situações. $O$ que importa é que a decisão tenha abstrato, tenha fundamento, tenha se baseado em uma tese de direito constitucional federal". (BUENO, Cassio Scarpinella. Curso sistematizado de direito processual civil, v. 9. Saraiva: 2009, p. 254).

${ }^{319}$ MANCUSO, Rodolfo de Camargo. Recurso extraordinário e recurso especial. São Paulo: RT, 2008, p. 146.
} 
em questões predominantemente de fato e predominantemente de direito, dificultando a vida do intérprete ${ }^{320}$.

Quem milita nos tribunais superiores sabe que um dos mais recorrentes fatores para que seja negado seguimento aos recursos especial ou extraordinário é justamente a invocação do reexame fático-probatório. Há incontáveis precedentes nesse sentido.

À primeira vista, nada mais acertado, afinal os recursos de sobreposição são recursos de direito estrito e de fundamentação vinculada, o que se alia ao perfil constitucional do STJ e do STF, que não devem funcionar como um terceiro grau de jurisdição.

Todavia, há situações de flagrante injustiça, sendo hipótese de jurisprudência defensiva, principalmente no âmbito dos tribunais estaduais e regionais.

Isso porque essas súmulas vêm sendo utilizadas pelos presidentes desses tribunais para negar seguimento aos recursos especial e extraordinário, contrariando a sistemática do art. $542, \S 1^{\circ}$, do CPC, que atribui aos tribunais a quo apenas a função de verificar a presença dos pressupostos gerais de admissibilidade de sobreditos recursos (preparo, tempestiva, etc.), mas jamais a eles é dado se imiscuir no mérito recursal. Desta feita, tem-se uma verdadeira usurpação de competência do relator do recurso no tribunal ad quem.

Ademais, também há situações de injustiça em que tais súmulas são invocadas defensivamente, uma vez que as hipóteses conjuradas no caso concreto não se enquadram na categoria genérica de reanálise dos fatos.

Em clara tentativa de corrigir parcialmente esses problemas, a própria jurisprudência pacificada no âmbito das nossas Cortes superiores tem cedido em determinadas situações excepcionais. Muito longe de pretender esgotar o tema, podem ser citados dois exemplos basilares desse movimento, que afastam a incidência das aludidas súmulas: $(i)$ a aceitação

\footnotetext{
320 “(...) o que se pode dizer é que, se de um lado o fenômeno jurídico envolve necessariamente fato/direito, a nosso ver pode-se falar em questões que sejam predominantemente de fato e predominantemente de direito. Ou seja, o fenômeno jurídico é de fato e de direito, mas o problema (= a questão) pode estar girando em torno do aspecto fático ou em torno do aspecto jurídico. Queremos com isso dizer que, embora indubitavelmente o fenômeno jurídico não ocorra senão diante de fato e de norma, o aspecto problemático desse fenômeno pode estar lá ou cá. E então se dirá que a questão é de fato ou de direito". (WAMBIER, Teresa Arruda Alvim. Recurso especial e ações de família. Revista de Processo n. ${ }^{\circ}$ 176, São Paulo: RT, out./2009, p. 36).
} 
do recurso quando se tratar de mera "qualificação jurídica dos fatos" ${ }^{321}$; e (ii) revisão de honorários advocatícios que tenham sido fixados em patamar irrisório ou exorbitante ${ }^{322}$.

\subsubsection{A Súmula 284 do STF e a questão da deficiência da fundamentação para a demonstração da repercussão geral}

A Súmula 284 reza que será inadmitido o recurso extraordinário que tiver fundamentação deficiente e não permitir a exata compreensão da controvérsia.

A origem do conteúdo da súmula, entretanto, é mais ampla e não se limita apenas ao recurso extraordinário, mas atinge, por exemplo, a rejeição da inicial por inépcia quando da narração dos fatos não decorrer logicamente o pedido.

Apesar de legítima a restrição veiculada na referida súmula, sua aplicação, muitas vezes indiscriminada, acaba impondo um óbice ilegítimo ao conhecimento do recurso extraordinário.

Uma situação que bem exemplifica essa assertiva diz respeito aos julgados dos Tribunais Superiores que não conhecem dos recursos nos quais o recorrente apenas aponta a violação à lei federal, sem demonstrar qual teria sido o dispositivo específico violado, mesmo que de sua narrativa seja perfeitamente compreensível qual o direito objetivo que restou ofendido $^{323}$. E pior: a restrição também se aplica aos recursos especiais fundados na alínea

321 “(...) O caso vertente não depende de revolvimento fático-probatório. Em verdade, cuida-se de qualificação jurídica dos fatos e provas já examinados pela Corte de origem. Afastada, portanto, a incidência da Súmula 7/STJ. (...).” (STJ, Segunda Turma, AgRg no REsp 1466111/SP, Relator Ministro HumberTo MARTINS, DJe de 14.11.2014). No mesmo sentido: “(...) 1. Qualificar juridicamente um fato é atribuir-lhe definição jurídica diversa da que deu o acórdão recorrido, sem, contudo, alterar a narrativa que dele fez o Tribunal de origem, motivo pelo qual não importa em reexame de provas. 2. Valorar juridicamente a prova é aferir se, diante da legislação pertinente, um determinado meio probatório é apto para provar algum fato, ato, negócio ou relação jurídica”. (STJ, Sexta Turma, AgRg no REsp 1465260 / GO, Relator Ministro SEBASTIÃO REIS JÚNIOR, DJe de 30.10.2014).

322 "PROCESSUAL CIVIL. HONORÁRIOS. EQUIDADE. REVISÃO. SÚMULA 7/STJ. Quanto à fixação de honorários advocatícios, o Superior Tribunal de Justiça, via de regra, mantém o valor estabelecido na origem, por força do óbice da Súmula 7/STJ. Somente em situações excepcionais, quais sejam: condenação em patamares ínfimos ou exorbitantes, a jurisprudência deste Tribunal autoriza a revisão do quantum fixado no acórdão a quo, o que não é o caso dos autos”. (STJ, Segunda Turma, AgRg no AREsp 548766 / RS, Relator Ministro HuMBERTO MARTINS, DJe de 14.10.2014).

323 "(...) A interposição de recurso especial fundado na alínea "a" do inciso III do art. 105 da Constituição Federal exige a indicação da lei federal entendida como violada e de seu respectivo dispositivo, sob pena de não conhecimento do apelo em razão de fundamentação deficiente. Incidência da Súmula n. 284 do Supremo Tribunal Federal. (...).” (STJ, Terceira Turma, AgRg no AREsp 546646/MS, Relator Ministro JOÃO OTÁVIO DE NORONHA, DJe de 25.09.2014). “(...) A ausência de indicação do dispositivo de lei federal violada, revela 
"c" do art. 105, III, da CF, ou seja, o recorrente deve apontar o dispositivo violado quando fundamenta seu inconformismo em dissídio jurisprudencial ${ }^{324}$, o que parece ser de uma ilogicidade aviltante.

Em outras decisões, mesmo o recorrente tendo apontado o dispositivo violado, o STJ não conhece do recurso quando não restar demonstradas as "razões jurídicas" pelas quais a parte considerou violada a norma jurídica ${ }^{325}$.

Esses exemplos demonstram, de maneira cabal, que a amplitude da súmula foi demasiadamente alargada, afinal o intuito primevo das Cortes Superiores não parece ter sido o de exigir que fossem apontados artigos, parágrafos, incisos ou alíneas, ou então que tal especificidade fosse aplicável também para fins de uniformização da jurisprudência.

No âmbito do STF, a deficiência na fundamentação também tem sido abordada em outra vertente, qual seja, a existência da repercussão geral. Isso porque também não são admitidos os recursos extraordinários que não apresentem preliminar fundamentada de repercussão geral, mesmo nas hipóteses em que o acórdão recorrido seja contrário à jurisprudência firmada no âmbito do próprio $\mathrm{STF}^{326}$.

Essa nova linha bem expõe o que Paulo Tedesco chama de "arredamento da jurisprudência [defensiva] de primeira geração para a de segunda.” Afinal, o que antes consistia apenas na Súmula 284 do STF, transformou-se na exigência de preliminar

a deficiência das razões do Recurso especial, fazendo incidir a Súmula 284 do STF: "É inadmissível o recurso extraordinário, quando a deficiência na sua fundamentação não permitir a exata compreensão da controvérsia." (STJ, Primeira Turma, AgRg no Ag 815186/RJ, Relator Ministro LuIZ FuX, DJ de 02.04.2007).

324 “(...) A jurisprudência desta Corte é assente no sentido de que a ausência de indicação dos dispositivos em torno dos quais teria havido interpretação divergente por outros Tribunais não autoriza o conhecimento do recurso especial, quando interposto com base na alínea "c" do permissivo constitucional. Incidência da Súmula 284 do STF. (...)”. (STJ, Segunda Turma, REsp 1274551/RS, Relator Ministro HuMBERTO MARTINS, DJe de 20.10.2011).

325 “.(..) Aplicável o enunciado 284 da Súmula do Supremo Tribunal Federal quando o recorrente, apesar de apontar o dispositivo legal, não indica precisamente as razões jurídicas pelas quais considerou violada a norma. (...)”. (STJ, Sexta Turma, AgRg no AREsp 380914/PI, Relatora Ministra MARIA THEREZA DE ASSIS MOURA, DJe de 19.11.2014). “(...) Razões que deixaram de demonstrar no que consistiu a alegada violação ao art. 535 do CPC, atraindo o óbice da Súmula $n^{o} 284$ do STF, aplicada por analogia. (...).” (STJ, Primeira Turma, AgRg no AREsp 514213/RJ, Ministra convocada Marga Tessler, DJe de 19.11.2014).

326 “(...) I-Nos termos do art. 327, e $\$ 1^{\circ}$, do RISTF, com a redação dada pela Emenda Regimental 21/2007, os recursos que não apresentem preliminar formal e fundamentada de repercussão geral serão recusados. $\underline{A}$ $\underline{\text { obrigação incide, inclusive, }} \underline{\text { quando }} \underline{\text { eventualmente aplicável o art. }} \underline{543-A,} \underline{\S} \underline{3^{\circ}}$, do $\underline{\text { Código de }} \underline{\text { Processo }} \underline{\text { Civil. }}$. Precedentes. (...)." (STF, Primeira Turma, AgRg no RE 575.425/SC, Relator Ministro RICARDO LEWANDOWSKI, DJe de 25.09.2009, grifos aditados). 
vinculada e suficientemente fundamentada de repercussão geral, sendo que a deficiência de fundamentação quanto a este quesito também constitui óbice intransponível.

\subsubsection{Exigência de preliminar formal demonstrando a repercussão geral do recurso extraordinário}

Muitos doutrinadores questionavam a constitucionalidade do $\S 2^{\circ}$ do art. 543-A do CPC, o qual estatui que "o recorrente deverá demonstrar, em preliminar do recurso, para apreciação exclusiva do STF, a existência da repercussão geral". Trata-se de verdadeiro requisito extrínseco de admissibilidade do recurso, não previsto no âmbito constitucional antes da EC n. ${ }^{\circ} 45 / 04$.

Como visto, o recurso extraordinário, juntamente com o especial, é de fundamentação vinculada, motivo pelo qual só é cabível nas estritas hipóteses constitucionais, sendo certo que a lei só pode delimitar seu procedimento (e, por conseguinte, as condições de admissibilidade), mas jamais seu cabimento.

Todavia, há doutrinadores que entendem que a preliminar formal seria desnecessária, até porque se trata de "matéria de ordem pública, uma vez que relativa ao juízo de admissibilidade do recurso extraordinário", a qual "deveria ser cognoscível de ofício", nos dizeres de Teresa ArRuda Wambier ${ }^{327}$.

Não obstante, “considerando que a repercussão geral diz respeito a questão constitucional, e não propriamente ao recurso, não se pode considerar imprescindível que o recorrente exponha as razões por que considera presente a repercussão geral. Tal comportamento é, sem sombra de dúvidas, conveniente e diligente; nunca necessário a que o STF analise a repercussão geral da questão constitucional. "328

Ainda que a fundamentação do recorrente seja deficiente, pode-se sustentar que o STF não deva deixar de analisar a existência de repercussão geral da questão suscitada, até por questão de isonomia com os demais jurisdicionados, caso, v.g., em que o recurso é interposto após o reconhecimento da repercussão geral da matéria.

\footnotetext{
${ }^{327}$ WAMBIER, T. A. A., op. cit., p. 300.

${ }^{328}$ TEDESCO, P. C., op. cit., p. 270.
} 
Inobstante o acima exposto, o regimento interno do STF, no art. 327, acentua ainda mais o rigor das formalidades para a exposição da repercussão geral, ao estatuir que " $a$ Presidência do Tribunal recusará recursos que não apresentem preliminar formal $e$ fundamentada de repercussão geral."

Em consonância com essa previsão, o tribunal passou, de fato, a exigi-la na análise do caso concreto $^{329}$.

\subsubsection{Irrecorribilidade da decisão que entende inexistir repercussão geral}

Outra medida adotada para restringir a atuação do STF consistiu em vedar a interposição de recurso contra a decisão que considera não haver repercussão geral, conforme leciona o $\S 5^{\circ}$ do art. 543-A do $\mathrm{CPC}^{330}$. Todavia, caberiam, em tese, ao menos embargos de declaração caso presentes seus requisitos, mesmo em se tratando de decisão plenária proferida pelo órgão de cúpula do Judiciário.

Contudo, inovando uma vez mais no plano infralegal, o art. 326 do RISTF dispôs que "toda decisão de inexistência de repercussão geral é irrecorrivel e, valendo para todos os recursos sobre questão idêntica, deve ser comunicada, pelo(a) Relator(a), à Presidência do Tribunal, para os fins do artigo subsequente e do artigo 329."

A exegese desse dispositivo resultou em vedação inclusive de pedido de reconsideração contra a decisão que nega a existência de repercussão geral ${ }^{331}$, mas considerando-se que somente lei federal pode dispor sobre matéria processual, trata-se de veículo inadequado para introduzir tal vedação, havendo quem sustente, portanto, a inconstitucionalidade do dispositivo em comento, como mais um exemplo da jurisprudência defensiva ${ }^{332}$.

\footnotetext{
329 “(...). II. Recurso extraordinário: repercussão geral: juízo de admissibilidade: competência. 1. Inclui-se no âmbito do juízo de admissibilidade - seja na origem, seja no Supremo Tribunal - verificar se o recorrente, em preliminar do recurso extraordinário, desenvolveu fundamentação especificamente voltada para a demonstração, no caso concreto, da existência de repercussão geral (C.Pr.Civil, art. 543-A, $\S 2^{o}$;

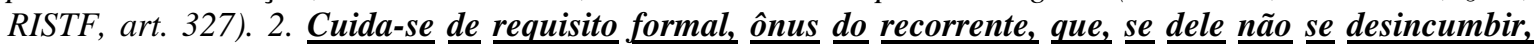

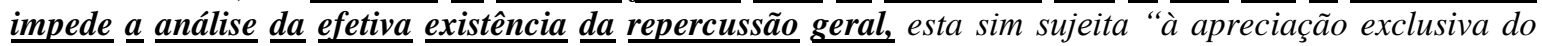
Supremo Tribunal Federal" (Art. 543-A, $\S 2^{\circ}$ )." (STF, Tribunal Pleno, DJe de 06.09.2007, grifos aditados).

330 " $\$ 5^{\circ}$ Negada a existência da repercussão geral, a decisão valerá para todos os recursos sobre matéria idêntica, que serão indeferidos liminarmente, salvo revisão da tese, tudo nos termos do Regimento Interno do Supremo Tribunal Federal."

${ }_{331}$ Cf. QO no RE 559.994/RS.

${ }^{332}$ TEDESCO, P. C., op. cit., p. 274.
} 


\subsubsection{A questão específica do preparo: as guias de recolhimento}

O preparo é um dos requisitos genéricos e extrínsecos de admissibilidade dos recursos e representa o pagamento prévio das custas e emolumentos cartoriais, devendo ser comprovado quando da interposição do recurso.

Trata-se, em verdade, de taxa judiciária imprescindível e vinculada ao uso, pelo jurisdicionado, do aparato estatal do Judiciário, cuja previsão foi alçada ao patamar legal, no âmbito do STJ, por intermédio da Lei n. ${ }^{\circ} 11.636 / 07$.

Sem seu pagamento e devida comprovação, o recurso será considerado deserto e, portanto, inadmitido, a não ser que haja a complementação do pagamento, nos termos do art. 511, $\S 2^{\circ}$, do CPC, em 5 (cinco) dias, previsão esta que tem sido aplicada pelos tribunais pátrios quando a parte recorrente efetua o recolhimento a menor, mas não quando o recolhimento sequer chega a ser efetuado.

Neste tema, porém, os jurisdicionados enfrentam inúmeras dificuldades, tendo em vista a existência de diversos tipos de guias, que devem ser recolhidas em bancos distintos, além da disparidade de critérios que permeiam cada um dos tribunais estaduais, regionais e superiores: na Justiça Federal, v.g., o preparo de um recurso de apelação corresponde a 0,5\% do valor da causa, ao passo que na Justiça Estadual tem-se um valor determinado por uma tabela escalonada. Justamente por isso, a permissão de complementação do preparo vai ao encontro do princípio do acesso à justiça.

Como frisado anteriormente, não basta o recolhimento da taxa judiciária, é preciso haver efetiva comprovação nos autos, que usualmente ocorre mediante a juntada da guia comprobatória do recolhimento, devidamente preenchida e quitada. E é nesta obrigatoriedade que residem e aparecem os problemas relacionados à jurisprudência defensiva.

Do mesmo modo que são variáveis as formas de cálculo das custas a serem recolhidas, as respectivas guias também variam conforme a localidade. 
No âmbito dos Tribunais Regionais Federais e dos Tribunais de Justiça estaduais, a interposição de um recurso extraordinário para o STF, bem como de um recurso especial para o STJ, exige o recolhimento das custas definidas na tabela dos tribunais superiores, assim como do chamado porte de remessa e retorno, outra taxa exigida para o trânsito dos autos do tribunal de origem para o STF e o STJ, sem a qual o recurso também será inadmitido.

A despeito de uma aparente unificação nos tribunais federais, o mesmo não se pode dizer dos tribunais estaduais, cada qual possuindo uma regulamentação própria.

Em São Paulo, por exemplo, o recolhimento do porte de remessa e retorno só pode ser feito no Banco do Brasil, mediante guia própria destinada ao Fundo Especial de Despesa do Tribunal de Justiça (FEDTJ), conforme o Provimento CSM n. ${ }^{\circ}$ 2.195/2014.

No Rio de Janeiro, os valores e procedimento para recolhimento das custas são regulados por meio da Portaria CGJ n. ${ }^{\circ}$ 94/2013, sendo que desde o início de 2013 todos os recolhimentos passaram a ser obrigatoriamente feitos por meio da GRERJ eletrônica (Guia de Recolhimento de Receita Judiciária).

Em Minas Gerais, por sua vez, há a Guia de Recolhimento de Custas e Taxas Judiciárias (GRCTJ), cujo pagamento pode ser feito em toda a rede bancária, conforme prevê o Provimento Conjunto n. ${ }^{\circ}$ 25/2012, do Presidente, Vice-Presidente e do Corregedor-Geral de Justiça de MG.

Por força do art. 41-B da Lei n. ${ }^{\circ}$ 8.038/90, que disciplina o assunto das despesas de porte de remessa e torno dos autos, concedendo poder de regulamentação aos tribunais superiores, a situação era extremamente caótica até pouco tempo atrás no que se refere à imprevisibilidade das regras procedimentais de recolhimento.

A despeito de atualmente ter unificado o recolhimento das custas e do porte de remessa e retorno por meio da GRU Cobrança, previsto na Resolução n. ${ }^{\circ}$ 01, de 2014, o STJ é, 
historicamente, uma das Cortes que mais modifica suas resoluções a respeito desse tema ${ }^{333}$, trazendo enorme insegurança jurídica aos cidadãos.

Brevemente, e apenas a título ilustrativo, mencionaremos algumas situações claras de jurisprudência defensiva, muitas das quais hoje não têm mais aplicabilidade, porquanto envolvem guias cujo preenchimento podia ser manual, mas hoje em dia há aquelas que só podem ser geradas por meio eletrônico (caso da própria GRU Cobrança).

A Resolução n. ${ }^{\circ}$ 12/2005, do STJ, ficou negativamente famosa, pois, a partir dela, tornouse obrigatória a inclusão do número do processo recorrido na GRU, sob pena de deserção $^{334}$, obrigação esta que foi suprimida na Resolução STJ n. ${ }^{\circ}$ 4/2007, assim permancecendo até o advento da resolução STJ n. ${ }^{\circ}$ 4/2010, que voltou a trazer essa exigência.

Até o ano passado, vigorava a Resolução STJ n. ${ }^{\circ}$ 4/2013, ordenando que o recolhimento se desse mediante a GRU Simples e que nos processos recursais fosse incluído o número do processo na origem ${ }^{335}$.

José Miguel Garcia Medina e Teresa Arruda Alvim Wambier apontam, nessa linha, que "tem-se decidido que ocorre deserção, se preenchida equivocadamente a guia de recolhimento da taxa devida por ocasião da interposição do recurso, deixando-se de indicar a que processo se refere o pagamento de tal taxa, a não ser que haja outro meio de verificar-se a veracidade do documento. "336

333 Entre 2004 e 2010, foram editadas nada menos do que oito resoluções. Basicamente, todas elas se referiam ora ao modo de preenchimento da GRU, ora à alteração do valor das taxas, ou então ao código a ser preenchido, bem como à necessidade e forma de anotação do número do processo respectivo.

${ }^{334}$ Segundo notícia extraída do sítio eletrônico do Tribunal, "para o pagamento do porte de remessa e retorno dos autos no âmbito do Superior Tribunal de Justiça (STJ), é necessário que conste na guia de recolhimento da União (GRU) o número do processo a que ela se refere. O entendimento da Segunda Turma do STJ é que, em caso contrário, pode-se considerar o recurso deserto, ou seja, extinto por falta de preparo. (...) Segundo o ministro [relator do caso narrado, Ministro Humberto Martins], a jurisprudência do tribunal é unânime ao exigir o exato preenchimento da guia de preparo a ser paga no Banco do Brasil, inclusive com a correta inscrição do número de referência. No caso apreciado, não há tal rubrica. O entendimento unânime da Segunda Turma é que deve constar na GRU o número do processo ao qual ela se refere sob pena de ser considerado deserto o recurso por falta de pagamento da guia." (STJ, disponível [online] em http://www.stj.gov.br/portal_stj/publicacao/engine.wsp?tmp.area=398\&tmp.texto=89150. . Acesso em 02.11.2012).

335 “Art. $7^{\circ}$. O recolhimento das custas judiciais e do porte de remessa e retorno dos autos será realizado mediante Guia de Recolhimento da União - GRU Simples. (...) $\S 6^{\circ}$ Nos processos recursais o campo "Número de Referência" da GRU deve ser preenchido com o número do processo no Tribunal de origem."

336 MEDINA, José Miguel Garcia; WAMBIER, Teresa Arruda Alvim. Recursos e ações autônomas de impugnação. São Paulo: RT, 2008, p. 97. 
Entretanto, causa espanto que diversas decisões monocráticas tenham sido proferidas no interregno dessas resouções STJ ora impondo, ora afastando a obrigatoriedade de inclusão do processo, adotando o entendimento de que, sem a correta anotação do número do processo, deve o recurso ser considerado deserto ${ }^{337}$.

Conquanto seja razoável identificar o preparo com o número do processo, seja por questões de organização interna, seja, ainda, por questões de ordem financeira, o mesmo não se pode dizer da reiterada inadmissibilidade dos recursos por supostas deficiências no preenchimento das guias ${ }^{338}$, caso, v.g., das decisões que consideraram que o preenchimento do número do processo, quando feito à mão pelo recorrente, não teria validade - sob o fundamento de que não haveria a possibilidade de comprovação de que a GRU constante dos autos não foi utilizada, indevidamente, em outros processos ${ }^{339}$.

O fundamento da proibição da anotação dos números de referência à caneta passa, segundo o próprio STJ, pela necessidade de se evitar "lesão aos cofres públicos", pois as guias, caso assim preenchidas, poderiam ser reutilizadas. O que se tem, nessa situação, é uma presunção de má-fé do recorrente, negando, verdadeiramente, a instrumentalidade das formas, havendo precedente, inclusive, que chegou ao disparate de considerar como protelatório agravo interposto contra decisão monocrática que inadmitiu recurso especial $^{340}$.

Em julgado recente a este respeito, em que as guias e seus comprovantes também foram preenchidos à mão, a Ministra MARIA ISABEL GALLOTTI citou a jurisprudência firmada no sentido de considerar tais situações como rasura por parte do recorrente ${ }^{341}$.

\footnotetext{
337 Cf. STJ, Terceira Turma, Edcl no AgRg no AgIn 826.927/SP, Relator Min. Paulo Furtado, DJe de 08.05.2009; STJ, Segunda Turma, Resp 933.291/PR, Relator Min. Herman Benjamin, DJe de 13.03.2009.

${ }^{338}$ FARIA, Márcio Carvalho. O formalismo exacerbado quanto ao preenchimento das guias de preparo: ainda a jurisprudência defensiva dos tribunais superiores. Revista de Processo n. ${ }^{\circ}$ 193, ano 36, mar./2011, p. 243.

339 "Observo que o Recurso Especial está irregular, pois o comprovante de recolhimento juntado aos autos não traz o número do processo a que se refere (fl. 384). Tal exigência é respaldada no art. 41-B da Lei 8.038/1990, prevista também na Resolução 20, de 25.11.2004, renovada na Resolução 12, de 7.6.2005, que foi alterada pelo Ato 141, de 7.7.2006, desta Corte (...). Sem a indicação do número do processo, não se comprova que as custas foram recolhidas." (STJ, Segunda Turma, REsp 1.120.666, Relator Ministro HERMAN BENJAMIN, DJe de 04.03.2010).

340 STJ, Quarta Turma, AgRg no AgIn 1.117.991/SP, Relator Min. LuIS FELIPE SALOMÃO, DJe de 11.05.2009.

341 “AGRAVO REGIMENTAL. RECURSO ESPECIAL. GUIA DE RECOLHIMENTO DA UNIÃO. NÚMERO DE REFERÊNCIA DO PROCESSO INDICADO NA GRU NÃO CORRESPONDE AO PROCESSO DE ORIGEM. RASURA. IMPOSSIBILIDADE DE VINCULAÇÃO DO PREPARO AOS AUTOS. NÃO COMPROVAÇÃO DO RECOLHIMENTO. IMPOSSIBILIDADE DE IDENTIFICAÇÃO E CONTROLE DE PAGAMENTO. DESERÇÃO. PRECEDENTES. 1. Os números de referência presentes nas Guias de
} 
Márcio Carvalho Faria ${ }^{342}$, entretanto, considera tênues as premissas apontadas em torno dos requisitos das guias de preparo, por seis motivos principais: (1) a má-fé não se presume, devendo ser provada no caso concreto; (2) não há qualquer vedação legal à anotação do número do processo à mão; (3) dado o grau atual de evolução tecnológica, o mero preenchimento digital da guia de preparo não impede a ocorrência de fraudes; (4) a própria Segunda Turma do STJ afastou a exigência de o DARF conter o número do processo a que se refere, por entender que não há possibilidade de fraude, tendo em vista que o original se encontra no processo respectivo; (5) mesmo não sendo indicado o número do processo, o valor é recolhido aos cofres do Estado, portanto o objetivo é cumprido, (6) sendo suficiente a comprovação do porte de remessa e retorno.

Outra hipótese constatada na prática do STJ diz respeito a agravo de instrumento que foi inadmitido em virtude de a parte agravante não ter juntado aos autos cópia da guia de porte de remessa e retorno, bem como de seu comprovante de pagamento. Com um detalhe: tal exigência não está prevista em lei, tanto assim que o relator da decisão, Ministro RAUL ARAúJo, reconheceu que se trata de requisito criado pela jurisprudência ${ }^{343}$; ou seja, nítida violação aos princípios da legalidade e, novamente, da segurança jurídica, sem olvidar do desapreço pela instrumentalidade, sendo certo que poder-se-ia aplicar o art. $511, \S 2^{\circ}$, do CPC, por analogia, para corrigir esse equívoco e permitir o conhecimento do recurso.

$\mathrm{Na}$ temática em apreço, tipicamente inserida entre as medidas caracterizadoras da jurisprudência defensiva, prevalece o formalismo exacerbado quanto ao preenchimento e comprovação do recolhimento das guias de preparo, que destoa, inclusive, da efetividade da jurisdição: se na seara recursal também vigora o princípio da legalidade, é altamente questionável a criação regimental ou casuística, pelos tribunais superiores, de requisitos

Recolhimento da União e nos seus respectivos comprovantes de pagamento foram preenchidos à mão, além de o número do CNPJ não conferir com o indicado na petição inicial. Jurisprudência da da Corte no sentido de que informação aposta à mão em documento que deveria ser preenchido eletronicamente é considerada como rasura. 2. Agravo regimental a que se nega provimento." (STJ, Quarta Turma, AgRg no REsp 972503/MG, Relatora Ministra MARIA IsABEL GALlOTTI, DJe de 30.05.2014).

${ }^{342}$ FARIA, M. C., op. cit., p. 246.

343 “(...) Não obstante a ausência de previsão no $\$ 1^{\circ}$ do art. 544 do CPC da exigência de juntada de cópia da guia de recolhimento do porte de remessa e retorno, para a formação do agravo de instrumento, a referida peça é essencial, na medida em que possibilita a aferição da regularidade formal do recurso, a qual está sujeita a duplo controle, nesta instância especial e na ordinária. (...).” (STJ, Quarta Turma, AgRg no Ag 1118335/SP, Relator Ministro RAUL ARAúJO, DJe de 19.10.2010). 
não previstos em lei, e, por outro lado, a vedação aos recorrentes quanto à possibilidade de complementação quanto a eventuais equívocos relativos às guias.

\subsubsection{A necessidade de ratificação de alguns recursos excepcionais:}

Passa-se, agora, à análise de outras duas práticas tormentosas para os recorrentes no âmbito dos Tribunais Superiores brasileiros, ambas relacionadas à intempestividade por antecipação recursal (ou intempestividade ante tempus).

A primeira delas diz respeito ao entendimento - inicialmente do STJ, e mais recentemente, ainda que com menor frequência, do STF - de que o recorrente deve ratificar o recurso excepcional interposto no tribunal de origem, antes do julgamento dos embargos de declaração, sob pena de inadmissibilidade.

A segunda atine à intempestividade dos recursos interpostos antes da publicação do acórdão que se pretende impugnar, ou seja, quando a parte toma ciência, sponte propria, do referido acórdão, e resolve se antecipar ao procedimento e interpor o recurso cabível.

\subsubsection{Os recursos prematuros}

Com relação à primeira hipótese, considerando que o prazo recursal é comum para ambas as partes, pode ocorrer que uma delas deseje opor, contra o acórdão que julgou a apelação, embargos de declaração com fins de prequestionamento, nos moldes das Súmulas 98 e 211 do STJ, ao passo que a contraparte pode interpor, desde logo, recurso especial e/ou extraordinário.

Considerando que os embargos de declaração interrompem o prazo para a interposição dos demais recursos, até que advenha a publicação do resultado do seu julgamento final, algumas situações podem surgir: (a) o litigante que já havia interposto o recurso excepcional poderia complementar seu recurso, caso a decisão impugnada tenha sido alterada pelo julgamento dos embargos, em nome do princípio da complementariedade; $(b)$ a parte pode se quedar inerte, seja porque os embargos não foram providos, seja porque seu resultado não lhe prejudica; $(c)$ o outro litigante, que havia oposto os aclaratórios, pode agora recorrer contra o novo acórdão a quo, ou ainda $(d)$ pode optar por não mais recorrer. 
O cerne da questão sob exame, pois, diz respeito ao ponto $(b)$, uma vez que, segundo o posicionamento dos tribunais, a parte não poderia ficar inerte, devendo "confirmar" ou "ratificar" seu recurso interposto, sob pena de configurar desistência tácita ou não esgotamento de instâncias ordinárias, razão pela qual para alguns tal recurso é considerado "prematuro" 344.

Mutatis mutandis, na primeira hipótese incidiria o óbice do art. 501 do CPC, aplicável aos agravos retidos que não são ratificados pela parte, fazendo com que eles não sejam admitidos.

De outro lado, parcela da jurisprudência justifica como não esgotamento das instâncias ordinárias, requisito este assegurado constitucionalmente para os recursos especial e extraordinário, respectivamnte nos arts. 105, III, e 102, III. Para essa corrente, enquanto não julgados os aclaratórios, ainda que o recurso excepcional tivesse sido interposto, não se poderia falar em "causa decidida" 345 .

Por fim, a terceira e mais forte corrente apregoa a inadmissibilidade do recurso, quando não ratificado, por "intempestividade prévia”, como se infere a partir de precedentes tanto do $\mathrm{STJ}^{346}$ como do $\mathrm{STF}^{347}$.

${ }^{344}$ FARIA, Márcio Carvalho. A jurisprudência defensiva dos tribunais superiores e a ratificação necessária (?) de alguns recursos excepcionais. Revista de Processo, ano 34, n. 167, jan./2009, p. 252. No mesmo sentido: JUNIOR, Jamacy José da Silva. O recurso antecipado e o recurso prematuro na visão dos Tribunais Superiores. Revista da Procuradoria-Geral do Banco Central n. ${ }^{\circ}$ 01, vol. 3, jun./2009, p. 196.

345 "PROCESSUAL CIVIL. AGRAVO REGIMENTAL EM AGRAVO DE INSTRUMENTO. INTERPOSIÇÃO DO RECURSO ESPECIAL ANTES DA PUBLICAÇÃO DO ACÓRDÃO DOS EMBARGOS DECLARATÓRIOS. NÃO-EXAURIMENTO DAS INSTÂNCIAS ORDINÁRIAS. INTEMPESTIVIDADE RECONHECIDA. 1. A Corte Especial, na sessão do dia 18 de abril do corrente ano (REsp 776.265/SC), decidiu que "por não estarem esgotadas as vias ordinárias, é intempestivo o Recurso Especial interposto antes dos Embargos de Declaração, tenham sido opostos pelo próprio recorrente do Recurso Especial ou mesmo pelo recorrido." 2. In casu, o Recurso Especial foi interposto antes do julgamento dos Embargos de Declaração, sem posterior ratificação, não ocorrendo, assim, o necessário esgotamento das instâncias ordinárias. 3. Agravo Regimental não provido." (STJ, Segunda Turma, AgRg no AgIn 777.590/SP, Relator Min. HERMAN BENJAMIN, DJ de 30.09.2008).

346 "EMBARGOS DE DIVERGENNCIA EM RECURSO ESPECIAL. RECURSO INTERPOSTO ANTES DO JULGAMENTO DOS EMBARGOS DE DECLARAÇÃO. NECESSIDADE DE RATIFICAÇÃO. DECISÃO DE ÚLTIMA INSTÂNCIA. 1. O recurso especial foi interposto antes do julgamento dos embargos de declaração da parte contrária sem posterior ratificação. 2. O julgamento dos embargos de declaração, com ou sem efeito modificativo, integra o acórdão recorrido, formando com ele o que se denomina decisão de última instância, passível de impugnação mediante o uso do recurso especial, nos termos da Constituição Federal. 3. É extemporâneo o recurso especial tirado antes do julgamento dos embargos de declaração, anteriormente opostos, sem que ocorra a necessária ratificação. 4 . Embargos de divergência conhecidos e acolhidos." (STJ, Corte Especial, EResp 796.854/DF, Relator Min. FERNANDO GONÇALVES, DJ de 06.08.2007). "AGRAVO REGIMENTAL NO AGRAVO EM RECURSO ESPECIAL. PROCESSUAL CIVIL. 
Observa-se, pois, na mesma linha dos outros casos de jurisprudência defensiva, que a exigência de ratificação de um recurso interposto constitui um requisito de admissibilidade não previsto pela legislação processual.

Para as situações em que o legislador previu a necessidade de ratificação, houve referência expressa, caso do agravo retido (art. 523, caput e $\S 1^{\circ}$, do CPC) e dos recursos excepcionais retidos (art. 542, $\S 3^{\circ}$ ), tratando-se do chamado efeito diferido, tão bem explanado por Cássio SCARPinella Bueno ${ }^{348}$.

O caso em tela, porém, não se enquadra nas hipóteses acima descritas, posto que a lei nada disse a respeito, sendo defesa tal exigência jurisprudencial ilegítima, por violação aos princípios do devido processo legal, da legalidade e da separação de poderes, dado que somente a União pode legislar sobre direito processual (ex vi do art. 22, I, da CF).

Ainda sobre o tema, tal exigência desconsidera a possibilidade de apresentação de recurso total ou parcial, a teor do art. 505 do CPC. Ora, se a justificativa para esse novel requisito é o fato de que, após o julgamento dos embargos, o acórdão recorrido pode ser modificado, o que demandaria expressa manifestação do recorrente, o recurso já interposto pode ainda ter validade com relação à parte não alterada, consubstanciando-se em recurso parcial ${ }^{349}$.

RECURSO ESPECIAL INTERPOSTO ANTES DA PUBLICAÇÃO DO JULGAMENTO DOS EMBARGOS DE DECLARAÇÃO. RATIFICAÇÃO POSTERIOR. INEXISTÊNCIA. INTEMPESTIVIDADE. SÚMULA 418/STJ. AGRAVO REGIMENTAL IMPROVIDO. 1. Nos termos da Súmula n. 418 do Superior Tribunal de Justiça, "é inadmissível o recurso especial interposto antes da publicação do acórdão dos embargos de declaração, sem posterior ratificação". 2. Na espécie, inviável o afastamento do óbice previsto na Súmula 418/STJ, pois os embargos de declaração foram opostos pela parte recorrente, situação que impõe o dever de ratificação posterior das razões do recurso especial. 3. Agravo regimental a que se nega provimento”. (STJ, Terceira Turma, AgRg no AREsp 535580/SP, Relator Ministro MARCO AuRÉLIO BELlizZE, DJe de 21.10.2014).

347 "1. Embargos de declaração recebidos como agravo regimental. 2. É extemporâneo o recurso extraordinário protocolado antes da publicação do aresto proferido nos embargos declaratórios, sem posterior ratificação. Precedentes. 3. Não tendo o recurso de agravo ultrapassado sequer o juízo de admissibilidade, impossível o processamento do apelo extremo e o enfrentamento da matéria de fundo. 4. Agravo regimental improvido." (STF, Pleno, EDcl no AgIn 685264/MG, Relatora Min. ELLEN GRACIE, DJ de 02.05.2008).

348 “(...) é possivel fazer referência a um efeito diferido dos recursos naqueles casos em que o seu processamento, isto é, a sua tramitação, o seu seguimento, depende da interposição e do recebimento de outro recurso. (...) Não é errado, para dar maior utilidade ao efeito aqui examinado, trazer para seus domínios o agravo retido. Nos casos em que não se opere o efeito 'regressivo' (...), é possível, à luz do art. $523, \S 1^{\circ}$, sustentar que o conhecimento do agravo retido depende da reiteração expressa pelo agravante em razões ou contrarrazões de apelação." (BUENO, Cássio Scarpinella. Curso sistematizado de direito processual civil: recursos, processos e incidentes nos tribunais: técnica de controle das decisões jurisdicionais, vol. 5. São Paulo: Saraiva, 2008, p. 78).

${ }_{349}$ FARIA, Márcio Carvalho. A jurisprudência..., op. cit., p. 259. 
Ademais, a possibilidade de interposição de recurso parcial serve para afastar, por completo, a tese anteriormente demonstrada de que a ratificação seria necessária sob pena de "não esgotamento das instâncias ordinárias". Por fim, parece um contrassenso inadmitir recurso "previamente intempestivo" ao início do dies a quo do prazo recursal ${ }^{350}$.

Por derradeiro, fica a ressalva de que até abril de 2007, tal entendimento não prevalecia no STJ, motivo pelo qual a Corte consolidou entendimento de que esse requisito só seria exigível para os julgados efetivados a partir de 18.04.2007, em respeito à segurança jurídica e ao direito adquirido, sendo o leading case o voto do Min. José Delgado no AgRg no AgIn 827.293/RS.

Entretanto, o Tribunal houve por bem modificar esse entendimento em maio de 2008, por meio da Corte Especial e por maioria de votos, nos autos dos ED no REsp 933.438/SP, aplicando-se esse efeito diferido para os processos já em curso, porquanto a decisão que não admite o recurso tem cunho declaratório e produz efeitos ex tunc.

Uma vez mais, observa-se flagrante ofensa a garantias fundamentais, em especial quanto à retroatividade maléfica. Além disso, a natureza da decisão que inadmite recurso não pode ter cunho variável, tanto é que intensas discussões foram travadas quando do julgamento dos ED no REsp 441.252/CE, prevalecendo a tese dos então Ministros LUIZ FUX e ELIANA Calmon, de que a eficácia seria ex tunc, ressalvando, porém, que em casos de patente boa-fé do recorrente ela seria ex nunc.

De todo modo, a questão foi objeto, em 2010, da Súmula 418 do STJ, aparentemente pacificando o entendimento do Tribunal a respeito deste tema: "é inadmissível o recurso especial interposto antes da publicação do acórdão dos embargos de declaração, sem posterior ratificação".

Posteriormente, a situação se agravou ainda mais em desfavor do acesso à justiça e segurança jurídica quando o STJ sedimentou o entendimento de que tal orientação se

350 Ver DINAMARCO, Cândido Rangel. Tempestividade dos recursos. Revista Dialética de Direito Processual n. ${ }^{\circ}$ 16, 2004, pp. 09-23. 
aplica mesmo nos casos em que os embargos de declaração tenham sido opostos pela parte contrária e tenham sido rejeitados, sem modificação do julgado ${ }^{351}$.

Entretanto, mesmo no seio do STJ há divergências sobre tal ônus imposto aos recorrentes, como se extrai de voto de recentíssima lavra do Ministro Luis Felipe SALOMÃo ${ }^{352}$, que possui entendimento diametralmente oposto, manifestado no Recurso Especial 1.129.215/DF, ainda pendente de julgamento.

\subsubsection{Os recursos antecipados}

Em que pese se tratarem de temas análogos, e que muitas vezes se confundem, há outra situação desgastante para os jurisdicionados que se diferencia, ligeiramente, dos recursos prematuros: é aquela em que se inadmite o recurso interposto antes da publicação do acórdão recorrido, daí falar-se em "recurso antecipado", porquanto teria ocorrido um ato processual antes do lapso temporal legalmente fixado ${ }^{353}$.

Durante muito tempo, podiam ser encontrados precedentes nesse sentido tanto do $\mathrm{STF}^{354}$ como do $\mathrm{STJ}^{355}$, fazendo cair por terra o princípio da instrumentalidade, haja vista que não se vislumbra qualquer prejuízo à contraparte, ou mesmo ao processo em si, quando ocorre a interposição de recurso antes da publicação do acórdão no órgão oficial, sobretudo nos

351 STJ, Quarta Turma, AgRg nos EDcl no AREsp 8.478/PR, Relator Ministro MARCO BuZZI, DJe de 27.02.2013.

352 STJ, Quarta Turma, AgRg no AREsp 569370/RJ, Relator Ministro LuIS FELIPE SALOMÃO, DJe de 11.11.2014.

${ }^{353}$ JUNIOR, J. J. da S., op. cit., p. 198.

354 "EMBARGOS DECLARATÓRIOS - OBJETO - ACÓRDÃO INEXISTENTE. Interpostos os declaratórios antes mesmo da formalização do provimento judicial - sentença ou acórdão - impõe-se, diante da falta de objeto, o não-conhecimento”. (STF, Segunda Turma, EDcl no HC 73662/MG, Relator Ministro Marco Aurélio Mello, DJ de 20.09.1996). No mesmo sentido: "Embargos de declaração. Interposição antes de publicado o acórdão embargado. Caráter prematuro. Objeto recursal ainda não definido de todo. Intempestividade reconhecida. Não conhecimento. Precedentes. Não se conhece de recurso interposto antes da publicação da decisão por impugnar". (STF, Segunda Turma, EDcl no AgRg no RE 421232/SE, Relator Ministro Cezar Peluso, DJe de 22.05.2009).

355 “EMBARGOS DE DECLARAÇÃO EM HABEAS CORPUS. OPOSIÇÃO ANTES DA PUBLICAÇÃO DO ACÓRDÃO. INTEMPESTIVIDADE. 1. O acórdão, enquanto ato processual, tem na publicação o termo inicial de sua existência jurídica, que em nada se confunde com aqueloutro com que se dá ciência às partes do conteúdo, intimação, que marca a lei como inicial do prazo para a impugnação recursal. 2. A extemporaneidade do recurso ocorre não apenas quando é interposto além do prazo legal, mas também quando vem à luz aquém do termo inicial da existência jurídica do decisório alvejado. Precedente do STF.

3. Constatado que os embargos declaratórios foram opostos sem que o acórdão embargado sequer tivesse sido publicado, não se constituindo, portanto, o dies a quo do termo legal para a interposição do recurso, deve-se tê-lo como extemporâneo. 4. Embargos de declaração não conhecidos”. (STJ, Sexta Turma, EDcl no HC 9275/RJ, Relator Ministro HAMILTON CARVALHIDO, DJ de 19.12.2002). 
tempos modernos, do processo eletrônico, em que a íntegra das decisões é disponibilizada antes mesmo da publicação.

Na prática, ao assim proceder, o recorrente dá-se por intimado do conteúdo da decisão, o que privilegia a celeridade processual e assegura o princípio constitucional da duração razoável do processo; negar-lhe tal faculdade, pois, representa exemplo claro de jurisprudência defensiva, que não pode ser tolerado, portanto vemos com alegria a mudança de posicionamento ao menos no âmbito do $\operatorname{STJ}^{356}$ (eis que no STF o entendimento permanece o mesmo ${ }^{357}$ ).

$* * * * *$

É tarefa árdua, e espinhosa, jogar luz sobre tão tormentoso tema da jurisprudência defensiva, sobretudo por ser plenamente compreensível que os Tribunais Superiores brasileiros se utilizem de mecanismos de autodefesa em face de um infinito arquivo de processos para julgar.

Conforme demonstrado ao longo desta Dissertação, esta é uma das medidas que os tribunais têm adotado como solução para desafogar a truncada tramitação recursal, afinal é certo que muitos recursos que acabam chegando às Cortes Superiores não são, de fato, dotados da necessária relevância para fins de uniformização do direito jurisprudencial,

356 "PROCESSUAL CIVIL. EMBARGOS DE DIVERGENNCIA. RECURSO INTERPOSTO ANTES DE PUBLICADA A DECISÃO RECORRIDA. INTEMPESTIVIDADE. PUBLICAÇÃO, ATO INDISPENSÁVEL. EXTEMPORANEIDADE. PRECEDENTES. ENTENDIMENTO DO RELATOR. NOVA POSIÇÃO DA CORTE ESPECIAL DO STJ. TEMPESTIVIDADE DO RECURSO. 1. A extemporaneidade de um recurso não se caracteriza apenas por sua interposição após o término do prazo recursal, mas, também, pela apresentação em data anterior à efetiva intimação das partes interessadas a respeito do teor da decisão a ser combatida. 2. A publicação da decisão que se pretende recorrer é ato indispensável para ensejar e justificar a interposição de novo recurso, sendo intempestivo o recurso manejado antes da publicação das conclusões do aresto no Diário da Justiça (STF, AG no 187448-1/SP e AGAED no 242842/SP, Rel. Min. Maurício Corrêa). Precedentes de todas as Turmas e da Corte Especial deste Tribunal Superior. Entendimento deste Relator com base em precedentes desta Casa Julgadora. 3. No entanto, embora tenha o posicionamento acima assinalado, rendo-me, ressalvando meu ponto de vista, à posição assumida pela maioria da Corte Especial deste Sodalício, pelo seu caráter uniformizador no trato das questões jurídicas no país que, com base em recente decisão (EResp 492461/MG), datada de 17/11/2004, consignou que a interposição de recursos contra decisões monocráticas ou colegiadas proferidas pelo STJ pode, a partir de agora, ser realizada antes da publicação dessas decisões na imprensa oficial. 4. Embargos de divergência acolhidos". (STJ, Corte Especial, EAg 522249 / RS, Relator Ministro JosÉ DELGADO, DJ de 02.02.2005).

357 "EMBARGOS DE DECLARAÇÃO EM MANDADO DE SEGURANÇA. OPOSIÇÃO ANTES DA PUBLICAÇÃO DO ACÓRDÃO EMBARGADO: EXTEMPORANEIDADE. PRECEDENTES. ALEGADA OMISSÃO, OBSCURIDADE E CONTRARIEDADE: NÃO OCORRÊNCIA. IMPOSSIBILIDADE DE REDISCUSSÃO DA MATÉRIA. PRECEDENTES. EMBARGOS DE DECLARAÇÃO REJEITADOS”. (STF, Segunda Turma, EDcl no MS 26.108/DF, Relatora Ministra Carmem Lúcia, DJe de 20.08.2013). 
tampouco carregam teses jurídicas que têm o condão de se multiplicar e afetar outro semnúmero de jurisdicionados.

Por outro lado, entretanto, a criação de inúmeros óbices estritamente formais, alguns deles citados anteriormente, acarretam a perda da chance das Cortes se depararem com casos concretos cuja tese deve ser interpretada e por elas fixada, contribuindo para a pacificação dos conflitos. E mais: o lado perverso dessa tônica dos Tribunais Superiores nos últimos anos é justamente a jurisprudência defensiva, que acaba por contrariar a própria função essencial que a Carta Maior atribuiu ao STJ e ao STF.

Temos, portanto, duas faces da mesma moeda. A criação de filtros recursais não é apenas desejável, e sim vital, mas desde que observados os direitos fundamentais dos cidadãos, aí incluída, obviamente, a observância ao princípio da legalidade, sem que represente ameaça de recrudescimento da insegurança jurídica.

Atento a isso, o legislador parece ter finalmente dado atenção às agruras e anseios dos jurisdicionados, por meio do Projeto do Novo CPC, razão pela qual parece ser iminente o esvaziamento, quase que por completo, da jurisprudência defensiva.

É o que se passa a analisar. 


\section{O PROJETO DO NOVO CÓDIGO DE PROCESSO CIVIL}

\subsection{A mens legislatoris: objetivos gerais}

A promulgação de um novo Código de Processo Civil, tal como se avizinha, representa, sem sombra de dúvidas, um marco na história legislativa brasileira. Em primeiro lugar, porque foi fruto de intensos debates, audiências públicas e objeto de diversas contribuições da comunidade jurídica como um todo, representada através de uma Comissão de Juristas (“Comissão"), composta por juristas de escol, designada especificamente para esta finalidade.

Tamanha é a relevância do tema - acompanhado, na mesma proporção, pela enorme dificuldade em se atingir uma redação de consenso - que o Projeto de Lei n. ${ }^{\circ} 166$ começou a tramitar no Senado Federal em 2010, foi alterado algumas vezes (por meio de emendas e substitutivos) até chegar à Câmara dos Deputados, por intermédio do Projeto de Lei n. ${ }^{\circ}$ $8.046 / 2010$.

Nesta Casa, o projeto também foi objeto de outra tantas alterações, resultando no Relatório do Deputado Paulo Teixeira, cuja versão final foi aprovada por unanimidade em 26.03.2014 ${ }^{358}$ e retornou ao Senado para aprovação do Substitutivo da Câmara ao PLS 166/2010, com os destaques apresentados pelos deputados.

Somente no início de dezembro a comissão temporária do Senado aprovou o texto-base ${ }^{359}$ e, posteriormente, o mesmo se deu com o Plenário da Casa, seguindo o texto para sanção presidencial, que deverá ocorrer no início de $2015^{360}$.

Para fins metodológicos, é esta última versão do Projeto do Novo CPC, consubstanciada no Substitutivo, que embasará as presentes reflexões, sem prejuízo à menção, quando

\footnotetext{
${ }^{358}$ Projeto de novo Código de Processo Civil: Versão Câmara dos Deputados - Redação final aprovada em 26.03.2014. Bahia: Editora JusPodivm, 2014. Disponível no site do Instituto Brasileiro de Direito Processual (IBDP), em http://www.direitoprocessual.org.br/download.php?f=5e513900c9435148931ae6646f9455fa.

${ }^{359}$ Senado Federal do Brasil. Novo Código de Processo Civil: comissão vota sugestões dos deputados no dia 4. Disponível [online] em http://www12.senado.gov.br/noticias/materias/2014/11/27/novo-codigo-deprocesso-civil-comissao-vota-sugestoes-dos-deputados-no-dia-4. Acesso em 04.12.2014.

360 Portal Migalhas. Novo CPC vai à sanção presidencial. Disponível [online] em http://www.migalhas.com.br/Quentes/17,MI213017,11049-Novo+CPC+vai+a+sancao+presidencial. Acesso em 17.12.2014.
} 
pertinente, ao Anteprojeto que foi o verdadeiro embrião dos trabalhos da Comissão (“Anteprojeto").

Pois bem.

Em que pese o fato de os princípios processuais virem todos delineados e delimitados na Constituição Federal, sendo ela seu fundamento de validade e legitimidade, a sistematização do processo civil pátrio é uma tarefa não apenas oportuna, mas, sobretudo, necessária.

O atual Código, de 1973, mostra-se anacrônico e carece de maior linearidade. Com o advento das reformas que lhe foram carreadas, principalmente ao longo das últimas duas décadas, ele se tornou assistemático, dificultando a vida do intérprete, dos magistrados e, principalmente, dos jurisdicionados. Todos os partícipes, então, reclamavam uma atualização do texto legal.

Cria-se, assim, um Codex novo, mas com a preocupação de não significar uma ruptura completa com o código vigente, como aponta ARRUDA ALVIM ${ }^{361}$, tendo em mente, simultaneamente, a coerência substancial e a harmonia interna corporis que as novéis disposições devem ter, além de virem alinhadas à legislação constitucional.

Não por outro motivo, o legislador deixou expresso, desde a Exposição de Motivos do Anteprojeto do novo CPC ("Exposicão de Motivos"), que, dentre os objetivos principais da Comissão que elaborou o texto, estão os de "estabelecer expressa e implicitamente verdadeira sintonia fina com a Constituição”, "reduzir a complexidade de subsistemas, como, por exemplo, o recursal", além de "imprimir maior organicidade ao sistema, dando-lhe mais coesão" 362 .

\footnotetext{
361 "A filosofia do PLS 166/2010, nas suas linhas mais gerais, é a seguinte: não se pretendeu fazer uma mudança radical ou bruca, até porque as mudanças radicais em direito geralmente não se justificam e, se feitas, não geram resultados satisfatórios. Procurou-se manter o que seria aproveitável do Código vigente e incorporar novidades tendo em vista uma resposta mais atual aos problemas que afligem os operadores do direito". (ARRUDA ALVIM, Eduardo Carreira. Notas sobre o Projeto de novo Código de Processo Civil. In: WAMBIER, Luiz Rodrigues; ARRUDA ALVIM WAMBIER, Teresa (coords). Doutrinas essenciais: Processo Civil, vol. I. São Paulo: RT, 2011, pp. 1.283-1.284).

${ }^{362}$ Exposição de Motivos do Anteprojeto do Novo Código de Processo Civil. Disponível [online] em: http://www.senado.gov.br/senado/novocpc/pdf/anteprojeto.pdf. Cf., também, MARINONI, L. G., MITIDIERO, D., op. cit., pp. 205-225.
} 
Quanto aos recursos, ilustrativamente, foi excluída uma antiga modalidade recursal (os embargos infringentes), foram reduzidas as hipóteses de cabimento de determinados recursos, tais como o agravo de instrumento, além, é claro, da simplificação do procedimento.

Ademais, outras preocupações externadas foram as de dotar o sistema processual de maior eficiência; aumentar sua funcionalidade; resolver problemas, principalmente pelo retorno do processo à sua função primordial de método de resolução de conflitos; aumentar a celeridade, justiça e atendimento às necessidades sociais.

Assim, além dos objetivos destacados acima, outros que foram mencionados na Exposição de Motivos foram: $(i)$ criar condições para que o juiz possa proferir decisão de forma mais rente à realidade fática subjacente à causa; (ii) simplificar, resolvendo problemas e reduzindo a complexidade de subsistemas, como, por exemplo, o recursal; e (iii) dar todo rendimento possível a cada processo em si mesmo considerado.

Neste esteio, aponta ARruda Alvim NetTo que, além de tentar imprimir maior organicidade e simplicidade à normativa processual, um objetivo claro do Projeto é "fazer com que o juiz deixe, na medida do possível, de se preocupar excessivamente com o processo, como se fosse um fim em si mesmo",363.

Ou seja, abandona-se o formalismo excessivo e, em contrapartida, visa-se ao máximo aproveitamento dos atos processuais. Em outras palavras, está o Projeto do Novo CPC mais moldado à busca da efetiva solução do conflito do que aos consagrados cânones científicos do processo ${ }^{364}$.

Se é certo que as últimas reformas promovidas no CPC vigente desde 1973 caracterizaramse por ampliar o conceito de manutenção e verticalização dos precedentes judiciais, não é menos certo que o Projeto do Novo CPC visa ampliar, ainda mais, o caráter vinculante das decisões judiciais, com o objetivo claro de desafogar a tramitação recursal nos tribunais e

\footnotetext{
363 NETTO, José Manoel de Arruda Alvim. Notas sobre o Projeto de Novo Código de Processo Civil brasileiro. Congressso dos 170 anos do IAB: Instituto dos Advogados Brasileiros, p. 89.

${ }^{364}$ ELIAS, C. E. S., op. cit., p. 83.
} 
diminuir os julgamentos díspares sobre o mesmo assunto, ou seja, aumentando a segurança jurídica $^{365}$.

Estrututalmente falando, o Projeto também divide o Código de Processo Civil em cinco livros, porém com disposição diversa da atualmente vigente. O Livro I traz a Parte Geral, ao passo que II aborda o processo de conhecimento; o Livro III trata do processo executivo, suas espécies e as defesas do executado; o IV, a seu turno, cuida dos processos nos tribunais e dos meios de impugnação das decisões judiciais; e, por último, o Livro V traz as disposições finais e transitórias. Dentre eles, portanto, o enfoque maior recairá sobre o quarto livro, posto que consentâneo com o tema tratado neste trabalho.

\subsection{A explícita preocupação com a uniformização e estabilização da jurisprudência}

Outro acentuado enfoque proposto pela Comissão no Projeto gira em torno do desiderato em prol da uniformização da jurisprudência, que acabou sendo refletido no texto final do Código.

Com efeito, a Comissão reconheceu que a existência de posicionamentos distintos e incompatíveis entre si a respeito de uma mesma norma jurídica, no âmbito dos Tribunais, gera intranquilidade e perplexidade aos jurisdicionados, razão pela qual "prestigiou-se, seguindo-se direção já abertamente seguida pelo ordenamento jurídico brasileiro, expressado na criação da Súmula Vinculante do Supremo Tribunal Federal (STF) e do regime de julgamento conjunto de recursos especiais e extraordinários repetitivos, tendência a criar estímulos para que a jurisprudência se uniformize, à luz do que venham a decidir tribunais superiores e até de segundo grau, e se estabilize,366.

Indo além, a Exposição de Motivos deixou claro que a função paradigmática dos tribunais superiores é inerente ao sistema, motivo pelo qual dedicou um capítulo inteiro, com três artigos, cheios de minúcias (Capítulo XV, arts. 520 a 522, que serão analisados adiante), para tratar não apenas do precedente judicial, mas também para mostrar a necessidade de observância da jurisprudência dominante dos tribunais superiores.

\footnotetext{
365 ARAÚJO, José Henrique Mouta. Processos repetitivos e o novo CPC - ampliação do caráter vinculante das decisões judiciais. In: ROSSI, Fernando et al. (coord). O futuro do processo civil no Brasil: uma análise crítica ao Projeto do Novo CPC. Belo Horizonte: Fórum, 2011, p. 311.

${ }^{366}$ Exposição de Motivos, p. 17.
} 
Afinal, a razão de ser dos tribunais superiores não é outra senão a de proferir decisões que moldem o ordenamento jurídico objetivamente considerado, e uma vez sedimentado entendimento em determinado sentido, ele deve ser mantido, a não ser que haja razões firmes recomendando sua alteração ${ }^{367}$.

Trata-se, nada mais nada menos, do que a desejada segurança jurídica, enxergada sob o viés da estabilidade jurisprudencial e traduzida por meio da proteção à confiança, tão bem explorado por J. J. Gomes CANOTILHo ${ }^{368}$.

Outro exemplo claro da preocupação com a segurança jurídica diz respeito à possibilidade de haver modulação dos efeitos da decisão que alterar jurisprudência dominante, seja sumulada ou não, para atribuir-lhe efeitos prospectivos ou limitar sua retroatividade.

Ademais, foram criados novos mecanismos para evitar a assim chamada "dispersão excessiva da jurisprudência", o que vai ao encontro da propalada diminuição do assoberbamento de trabalho do Poder Judiciário, temática essa que motivou e introduziu a presente Dissertação.

A título exemplificativo, antes de adentrar cada seara específica, foram mencionadas, ainda no campo da Exposição de Motivos, as seguintes medidas que se pretende adotar no Projeto do Novo CPC:

(1) complementação e reforço da eficiência do regime de julgamento dos recursos repetitivos, passando a ser permitida a suspensão do procedimento das demais ações, tanto em primeira instância como nos demais recursos extraordinários ou especiais que estejam em tramitação;

(2) valorização das súmulas e precedentes dos Tribunais Superiores;

(3) criação do incidente de resolução de demandas repetitivas.

\footnotetext{
${ }^{367}$ Exposição de Motivos, pp. 18-19.

368 “Esses dois princípios - segurança jurídica e proteção da confiança - andam estreitamente associados, a ponto de alguns autores considerarem o princípio da confiança como um subprincípio ou como uma dimensão específica da segurança jurídica." (CANOTILHO, José Joaquim Gomes. Direito constitucional e teoria da Constituição. Coimbra: Almedina, 2000, p. 256).
} 
Outrossim, em claro desapego ao formalismo exacerbado, devidamente analisado e exemplificado por intermédio da jurisprudência defensiva, e fazendo prevalecer o princípio da instrumentalidade, o Projeto do novo CPC mostra sua vertente que beneficia, sobremaneira, o julgamento do mérito dos recursos, porquanto permite que os Tribunais Superiores o apreciem, quando a questão debatida for relevante mesmo nas hipóteses em que não estejam presentes todos os requisitos de admissibilidade, dada a relevância da questão debatida.

Ainda nesse contexto, os recursos dirigidos ao STJ e ao STF sofreram significativas - e positivas - mudanças. A começar pela regra expressa de aproveitamento do processo ao máximo, de maneira a permitir a fungibilidade dos recursos especial e extraordinário, até chegar às súmulas, que foram extremamente valorizadas a ponto de ser permitido ao relator dos recursos (especial ou extraordinário) negar-lhes provimento quando forem contrários a "súmula do STF, do STJ ou do próprio tribunal", ex vi do art. 945, IV, "a" do Projeto do Novo CPC.

Por outro lado, também na seara do aumento dos poderes dados ao relator, passará a ser possível que se dê provimento a recurso, monocraticamente, se a decisão recorrida contrariar "súmula do STF, do STJ ou do próprio tribunal", acórdão proferido pelas Cortes Superiores em julgamento de recursos especial e extraordinário repetitivos, ou ainda no bojo do incidente de resolução de demandas repetitivas (art. 945, V, "a" a "c").

Tal redação atenua as críticas tecidas por alguns doutrinadores ao Anteprojeto, porquanto a redação anterior não era ampla o bastante para abranger todos os precedentes que firmaram ratio decidendi sobre determinada questão jurídica ${ }^{369}$.

Outro exemplo latente do máximo aproveitamento processual diz respeito à regra positivada no § único do art. 1047 do Projeto do Novo CPC, a qual reza que a admissão do recurso extraordinário ou especial por um fundamento devolve ao tribunal o conhecimento dos demais e de todas as questões relevantes que os envolvem.

O mesmo vale para a oposição de embargos com fins de prequestionamento: ainda que inadmitidos, o prequestionamento é tido como realizado (art. 1.038).

${ }^{369}$ MARINONI, L. G.; MITIDIERO, D., op. cit., pp. 172-173. 


\subsection{O tratamento diferenciado destinado ao precedente judicial}

O precedente, no Projeto do Novo $\mathrm{CPC}$, recebeu um tratamento nunca antes visto nos códigos processuais pátrios.

Logo de início, vê-se que um capítulo inteiro lhe foi dedicado (Capítulo XV), mostrando os fundamentos pelos quais o precedente foi erigido à condição de suma importância na Seção V do texto do Código que foi remetido à sanção presidencial, que trata da coisa julgada: além da mudança topológica, o precedente, ao ser alçado a capítulo autônomo do Código, demonstra sua relevância para a promoção do respeito à estabilidade, inteireza e coerência da jurisprudência dos tribunais. Afinal, é isso que verdadeiramente impõe o caput do art. $520^{370}$.

Por oportuno, já se faz necessário lançar mão de uma discussão que possivelmente exigirá reflexão por muitos processualistas. É que o art. 520 do Projeto, logo após explicitar os valores que deseja proteger por meio da consolidação do precedente judicial, trata, nos seus $\S \S 1^{\circ}$ e $2^{\circ}$, da edição, pelos tribunais, de "enunciados de súmulas correspondentes a sua jurisprudência dominante" $\left(\S 1^{\circ}\right)$, devendo, cada um deles, ater-se às circunstâncias fáticas dos precedentes que motivaram a sua criação $\left(\$ 2^{\circ}\right)$.

Ora, duas leituras podem ser extraídas de imediato: a primeira, de que certamente por "precedente" o legislador não quis dizer "enunciados de súmulas da jurisprudência dominante", afinal são institutos claramente distintos e de logna data positivados em nosso direito.

A segunda questão a ser colocada é: qual a definição de precedente para fins do Projeto do Novo CPC? Essa tormentosa pergunta permeará diversas passagens do Projeto, que muitas vezes fala em decisões e precedentes, subsequentemente, mas sem diferenciá-los objetivamente.

Pelos motivos já expostos no Capítulo 2 desta Dissertação e que não se convém repetir, sabemos que a noção de precedente é mais ampla, consistindo em uma decisão que possui qualidades externas que escapam ao seu conteúdo. Daí nossa ponderação de que a

370 “Art. 520. Os tribunais devem uniformizar sua jurisprudência e mantê-la estável, íntegra e coerente”. 
Comissão deveria ter definido, logo no art. 520, quais decisões têm o condão de se tornar precedentes ou não.

Independentemente disso, sem sombra de dúvidas o legislador, na redação atual, preocupase em explicar o porquê da necessidade de valorização e observância dos precedentes, fazendo cair por terra a crítica tecida por alguns autores ${ }^{371}$, referentes à redação que constou do Anteprojeto, de que teria sido desperdiçada justamente a oportunidade de justificar o respeito aos precedentes em nossa ordem jurídica.

E o Projeto não parou por aí. Pelo contrário, foi muito além no art. 521, por meio do qual tratou de dotar o art. 520 de efetividade, invocando os princípios da legalidade, da segurança jurídica, da duração razoável do processo, da proteção da confiança e da isonomia para determinar a observância das seguintes disposições, quando resultarem de decisões tomadas por maioria no âmbito do colegiado ${ }^{372}$ :

(i) os juízes e tribunais seguirão as decisões e os precedentes do Supremo Tribunal Federal em controle concentrado de constitucionalidade;

(ii) os juízes e tribunais seguirão os enunciados de súmula vinculante, os acórdãos e os precedentes em incidente de assunção de competência ou de resolução de demandas repetitivas e em julgamento de recursos extraordinário e especial repetitivos;

(iii) os juízes e tribunais seguirão os enunciados das súmulas do Supremo Tribunal Federal em matéria constitucional e do Superior Tribunal de Justiça em matéria infraconstitucional;

(iv) não sendo a hipótese de aplicação dos incisos I a III, os juízes e tribunais seguirão os precedentes: (a) do plenário do Supremo Tribunal Federal, em controle difuso de constitucionalidade; (b) da Corte Especial do Superior Tribunal de Justiça, em matéria infraconstitucional.

${ }^{371}$ MARINONI, L. G.; MITIDIERO, D., op. cit., p. 164.

372 "Art. 521. (...) $\& 3^{\circ} \mathrm{O}$ efeito previsto nos incisos do caput deste artigo decorre dos fundamentos determinantes adotados pela maioria dos membros do colegiado, cujo entendimento tenha ou não sido sumulado". 
Nas hipóteses acima elencadas, o Projeto parece ter inovado na situação descrita no item (iii) supra. Isso porque, ao dizer que os juízes e tribunais (estaduais ou regionais) devem passar a observar as súmulas do STF (quando em matéria constitucional) e do STJ (em matéria infraconstitucional), é possível aventar a seguinte conclusão: de que foi criada uma nova modalidade de súmula vinculante, qual seja, aquela que vincula apenas os juízes e tribunais a quo, mas não a Administração Pública.

Ou seja, em se tratando de súmulas em matéria constitucional editadas pelo STF, e em matéria infraconstitucional pelo STJ, serão tais súmulas vinculantes para "os juízes e tribunais".

As demais hipóteses são tipicamente formas de valorizar os pronunciamentos dos Tribunais Superiores, novamente com o intuito de proceder à uniformização dos entendimentos para as instâncias inferiores ${ }^{373}$.

O Projeto do Novo CPC não descuidou de abordar tanto a formação como a aplicação do precedente. $\mathrm{O} \S 1^{\circ}$ do art. 521, neste esteio, faz remissão ao art. 10 e ao art. $499, \S 1^{\circ}$, que tratam da motivação das decisões judiciais, tal como explicado alhures. Assim, não têm o condão de servir como precedentes futuros os fundamentos prescindíveis para o alcance do resultado fixado no acórdão e aqueles que não foram adotados pela maioria dos membros do colegiado $\left(\S^{\circ}\right)$. Ainda que tacitamente, portanto, parece o legislador ter ao menos indicados quais motivos constituirão os precedentes.

De suma relevância as previsões contidas nos $\S \S 5^{\circ}$ a 11 do extenso art. 521 , ao tratarem da possibilidade de alteração ou afastamento de determinado entendimento pelo tribunal.

Com efeito, poderá exigir-se solução jurídica diversa daquela veiculada no precedente, mas para tanto o órgão jurisdicional deverá demonstrar, fundamentadamente, que a fattispecie é distinta, ou então que envolve questão jurídica não examinada. Consequentemente, o fundamento poderá derivar de alteracação ou revogação de norma em que a matéria se

\footnotetext{
${ }^{373}$ Porém, fica a dúvida - que certamente deverá ser objeto de estudo mais acurado por parte dos juristas num futuro próximo, não havendo espaço nesta Dissertação - é saber se todas essas medidas em prol do reinado quase que absoluto das Cortes Superiores não representa o desprestígio das decisões de primeiro e segundo graus.
} 
fundou, ou ainda pode ter por fundamento mudança política, social ou econômica $\left(\S 7^{\mathbf{0} 74}\right)$. Tal previsão se afigura extremamente positiva para fins de se evitar o congelamento jurisprudencial, de forma semelhante ao que ocorre com as súmulas vinculantes.

De forma inovadora, o $\S 8^{\circ}$ permite, para fins de rediscussão da tese, e quando for profícua, a participação de pessoas, órgãos e entidades em audiências públicas realizadas com esta finalidade ${ }^{375}$.

O $§ 10$, a seu turno, traz a possibilidade de o tribunal promover a modulação dos efeitos da decisão que supera entendimento anterior, seja de jurisprudência dominante (sumulada ou não), seja, ainda, de precedente ${ }^{376}$.

Com efeito, os $\S \S 5^{\circ}$ a 11 do referido art. 521 tratam da aplicação, no direito brasileiro, do instituto do overruling, sobre o qual já se discorreu nesta Dissertação. Ocorre, porém, que a revogação do precedente nos EUA e no common law em geral sempre produz, como regra, efeitos retroativos. Afinal, se a revogação significa a admissão de que a tese até então veiculada no precedente estava equivocada, ou então não mais se apresenta em consonância com os valores sociais ou jurídicos, nada mais lógico do que aceitar que a decisão deve retroagir para alcançar situações pretéritas, nas quais tenha sido empregada a mesma ratio decidendi, conforme ensinam MARINONI e MITIDIERo ${ }^{377}$.

Todavia, como visto anteriormente, essa tendência tem sido cada vez mais flexibilizada, inclusive no direito comparado, por meio das categorias do "prospective overruling", de maneira que a Comissão parece estar aberta também a esses novos influxos do common law.

Por derradeiro, o art. 522 trata de explicitar o que se considera por "julgamento de casos repetitivos", a saber: aquele resultante de decisão proferida em incidente de resolução de

\footnotetext{
374 " $\$ 7^{\circ}$ A modificação de entendimento sedimentado poderá fundar-se, entre outras alegações, na revogação ou modificação de norma em que se fundou a tese ou em alteração econômica, política ou social referente à matéria decidida".

375 " $\$ 8^{\circ} \mathrm{A}$ decisão sobre a modificação de entendimento sedimentado poderá ser precedida de audiências públicas e da participação de pessoas, órgãos ou entidades que possam contribuir para a rediscussão da tese".

376 "§ 10. Na hipótese de alteração de jurisprudência dominante, sumulada ou não, ou de precedente, o tribunal poderá modular os efeitos da decisão que supera o entendimento anterior, limitando sua retroatividade ou lhe atribuindo efeitos prospectivos".

${ }^{377}$ MARINONI, L. G.; MITIDIERO, D., op. cit., p. 169
} 
demandas repetitivas e em sede de recursos especial e extraordinário repetitivos. Ambos os temas serão abordados com mais vagar logo adiante.

Além de um capítulo específico destinado à figura do precedente, há outras menções ao tema em capítulos e seções distintas, tornando-o recorrente numa análise sistemática do Projeto do Novo CPC.

Uma delas é extraída no artigo referente aos requisitos da sentença, mais especificamente da motivação: ao julgador não bastará invocar súmula ou precedente para fundamentar a decisão, sem que haja a identificação de seus fundamentos determinantes ou demonstração de que o caso concreto se amolda a tal precedente ou súmula (art. 499, §1 ${ }^{\circ}, \mathrm{V}$ ).

A contrario sensu, tampouco considerar-se-á devidamente fundamentada a decisão que deixar de seguir enunciado de súmula, jurisprudência ou precedente que tenha sido invocado por uma das partes sem demonstrar (a) o porquê da sua inaplicabilidade ao caso em apreço, ou (b) que tal entendimento fora superado (art. $\left.499, \S 1^{\circ}, \mathrm{VI}\right){ }^{378}$.

Outra preocupação latente com a clareza da fundamentação veio delimitada no $\S 4^{\circ}$ do art. 954 do Projeto, que, inserido no capítulo referente à Ordem dos Processos no Tribunal (capítulo I do Livro III - Dos Processos nos Tribunais e dos Meios de Impugnação das Decisões Judiciais), impõe que as questões relevantes do caso em análise "devem ser indicadas de modo claro no acórdão", a fim de respeitar o precedente judicial, "na forma do art. 521".

Também há menção ao precedente no art. 1000, III, sendo uma das hipóteses de cabimento da reclamação, de modo a garantir a observância de decisão ou precedente do STF em controle concentrado de constitucionalidade.

\footnotetext{
378 “Art. 499. São elementos essenciais da sentença: (...). § $1^{\circ}$ Não se considera fundamentada qualquer decisão judicial, seja ela interlocutória, sentença ou acórdão, que: (...) V-se limitar a invocar precedente ou enunciado de súmula, sem identificar seus fundamentos determinantes nem demonstrar que o caso sob julgamento se ajusta àqueles fundamentos; VI - deixar de seguir enunciado de súmula, jurisprudência ou precedente, sem demonstrar a existência de distinção no caso em julgamento ou a superação do entendimento".
} 
Não obstante, será automaticamente reconhecida repercussão geral do recurso que impugnar decisão que contrarie decisão ou precedente do STF, à luz do art. 1.048, §3, $\mathrm{I}$, do Projeto do Novo CPC.

Ainda no contexto dos recursos, outra novidade do Projeto do Novo CPC é a unificação dos agravos contra decisões denegatórias de seguimento a recursos especial e extraordinário, sendo que ambas as hipóteses passaram a ser atacadas por meio do agravo extraordinário, regulado no art. 1055 e seguintes.

Um dos requisitos que é exigido do agravante diz respeito à demonstração de que o caso em apreço se distingue do precedente invocado ou, ainda, que houve superação da tese, quando o seguimento do recurso for negado, por exemplo, com base em entendimento consolidado em recurso repetitivo ${ }^{379}$.

Por derradeiro, não poderia deixar de ser mencionada outra vertente da utilização do precedente como técnica de aceleração de julgamento - e de economia processual - que é a inclusão de um capítulo específico sobre a improcedência liminar do pedido, cabível para os processos que dispensem a fase instrutória.

Antes mesmo da citação do réu, o juiz poderá julgar liminarmente improcedente o pedido nas hipóteses do art. 333, ou seja, nas hipóteses em que o pedido contrariar: súmula do STJ ou do STF; acórdão desses tribunais proferidos em sede de recursos repetitivos; entendimento consagrado em incidente de resolução de demandas repetitivas ou assunção de competência (outra novidade do Projeto); norma jurídica extraída de dispositivo expresso de ato normativo; ou enunciado de súmula de Tribunal de Justiça sobre direito local.

\footnotetext{
379 “ $\$ 1^{\circ}$ Sob pena de não conhecimento do agravo extraordinário, incumbirá ao agravante demonstrar, de forma expressa: II - a existência de distinção entre o caso em análise e o precedente invocado ou a superação da tese, quando a inadmissão do recurso: a) especial ou extraordinário fundar- se em entendimento firmado em julgamento de recurso repetitivo por tribunal superior; $b$ ) extraordinário fundarse em decisão anterior do Supremo Tribunal Federal de inexistência de repercussão geral da questão constitucional debatida".
} 


\section{$5.4 \mathrm{O}$ incidente de resolução de demandas repetitivas}

Uma das grandes inovações trazidas pelo Projeto é o chamado incidente de resolução de demandas repetitivas, previsto nos arts. 988 a 999, cujo objetivo é o de evitar a "dispersão excessiva da jurisprudência", "atenuar o assoberbamento de trabalho no Poder Judiciário" e promover o andamento mais célere dos processos, como constou da já citada Exposição de Motivos do Codex que se pretende aprovar.

Além disso, por dispersão excessiva da jurisprudência leia-se controvérsia que seja apta a gerar multiplicação excessiva de demandas, contendo o risco de que sejam proferidas decisões conflitantes. Pretende-se, pois, desafogar o Judiciário em primeiro grau de jurisdição $^{380}$, decidindo-se, com eficácia vinculante, conflitos de massa.

Tal incidente, com nítida inspiração nos Musterverfahren do direito alemão ${ }^{381}$, pode ser suscitado (i) quando houver "efetiva repetição de processos" que represente perigo de ofensa à isonomia e à segurança jurídica, e (ii) nos quais a questão controvertida seja unicamente de direito. Ademais, pode ser suscitado perante Tribunal de Justiça ou Tribunal Regional Federal, desde que na pendência de "qualquer causa de competência do Tribunal”, ex vi do art. 988, caput e $\$ \S 1^{\circ}$ e $2^{\circ}$ do Projeto.

A legitimação para seu requerimento é ampla: pode ser requerido de ofício (e por ofício) pelo relator ou pelo órgão colegiado; pelas partes; pelo Ministério Público; pela Defensoria Pública, pela pessoa jurídica de direito público ou por associação civil cuja finalidade institucional inclua a defesa do interesse ou direito objeto do incidente, mediante petição $\left(\S 3^{\circ}\right.$ do art. 988$)$.

O Projeto do Novo CPC acentuou, ainda mais, a relevância do instrumento para a uniformização da jurisprudência ao incluir previsão de que, mesmo que ocorra a desistência ou abandono da causa, o mérito do incidente poderá ser analisado $\left(\S 5^{\circ}\right)$.

\footnotetext{
${ }^{380}$ NETTO, J. M. de A., op. cit., p. 97.

381 A decisão oriunda desse incidente, no direito alemão, serve como modelo para os demais processos em que as partes estejam em idêntica situação, ainda que não se trate do mesmo autor ou do mesmo réu. Cf. WITTMANN, Ralf-Thomas. Il contenzioso 'di massa' in Germania. In: ALESSANDRO, Giogetti; VALLEFUOCO, Valerio. Il contenzioso di massa in Italia, in Europa e nel mondo. Giuffrè: Milão, 2008. p. 178).
} 
Na verdade, portanto, esse incidente constitui, na essência, incidente de uniformização de jurisprudência com caráter vinculante, com a suspensão de casos análogos nos juízos de primeiro e segundo graus, motivo pelo qual o Projeto propôs a supressão do incidente de uniformização de jurisprudência.

Procedimentalmente, uma vez admitido o incidente, o relator determinará a suspensão dos processos pendentes, individuais ou coletivos, que estejam em tramitação no estado ou região, suspendendo-se a prescrição nos casos em que a questão de direito é repetida (art. $990, \S \S 1^{\circ}$ e $\left.5^{\circ}\right)$.

Será ele julgado, no período máximo de 1 (um) ano ${ }^{382}$, com plena observância do contraditório e ampla defesa, pelo órgão do tribunal que vier a ser definido no regimento interno (art. 991, caput).

Julgado o incidente, a tese jurídica será replicada (art. 995): (i) a todos os processos individuais ou coletivos que versem sobre idêntica questão de direito e que tramitem na área de jurisdição do respectivo tribunal, inclusive àqueles que tramitem nos juizados especiais do respectivo estado ou região; e (ii) aos casos futuros que versem idêntica questão de direito e que venham a tramitar no território de competência do respectivo tribunal.

Naturalmente, é cabível a revisão da tese jurídica consolidada, por pedido formulado por qualquer dos legitimados, sem prejuízo da interposição de recurso especial ou extraordinário contra a decisão ( $\operatorname{art.} 995, \S \S 3^{\circ}$ e $4^{\circ}$ ), que terá efeito suspensivo automático e tem repercussão geral presumida.

É interessante notar que, se porventura vierem a ser interpostos recursos especial e/ou extraordinário, a tese fixada pelos Tribunais Superiores prevalecerá automaticamente e deverá ser observada em todos os processos individuais e coletivos idênticos (art. 995, $\left.\S 5^{\circ}\right)$.

\footnotetext{
${ }^{382}$ Gozando de preferência sobre os demais feitos, com exceção de habeas corpus e processos que envolvam réu preso.
} 
Também em prol da segurança jurídica, o Projeto do Novo CPC autoriza a qualquer dos legitimados que requeira, perante o STF ou STJ, a suspensão de todos os processos individuais e coletivos, no território nacional, que versem sobre a mesma questão objeto do incidente instaurado (art. 997).

Por último, o art. 1.042, $\$ 4^{\circ}$ do Projeto, ao tratar do incidente de resolução de demandas repetitivas, permite ao Presidente do STF ou do STJ, quando receber requerimento de suspensão de processos em que se discuta questão federal constitucional ou infraconstitucional, estender a eficácia a todo o território nacional, até ulterior decisão do recurso interposto, considerando "razões de segurança jurídica ou de excepcional interesse social ${ }^{\prime 383}$, ou seja, trata-se de previsão semelhante àquela citada acima, constante do art. 997, permitida ex officio pelos tribunais, e não apenas após requerimento dos legitimados.

A previsão do incidente é elogiada pela doutrina ${ }^{384}$ que já se debruçou sobre o tema, porquanto visa a promover maior segurança jurídica, confiança, igualdade e coerência da ordem jurídica, evitando o proferimento de decisões conflitantes, a partir da fixação da tese a ser observada pelos órgãos do Poder Judiciário na análise da questão apreciada.

Consiste, em síntese, em um sistema que se aproxima do que já existe quanto aos recursos fundados em idêntica questão de direito (recursos repetitivos) perante o STJ, que é estendido aos tribunais de segundo grau de jurisdição. Segundo Alvim NeTto, “o que fez o Projeto foi estabelecer, para as demandas repetitivas, uma disciplina análoga àquela referente aos procedimentos da repercussão geral nos recursos extraordinários e do julgamento de recursos repetitivos no STJ ${ }^{, 385}$.

\footnotetext{
383 " $\$ 4^{\circ}$ Quando, por ocasião de incidente de resolução de demandas repetitivas, o presidente do Supremo Tribunal Federal ou do Superior Tribunal de Justiça receber requerimento de suspensão de processos em que se discuta questão federal constitucional ou infraconstitucional, poderá, considerando razões de segurança jurídica ou de excepcional interesse social, estender a eficácia da medida a todo o território nacional, até ulterior decisão do recurso extraordinário ou do recurso especial interposto".

${ }^{384}$ MARINONI, L. G.; MITIDIERO, D., op. cit., p. 178. MONTEIRO. A. L., op. cit., p. 271.

${ }^{385}$ NETTO, J. M. de A., op. cit., p. 98.
} 


\subsection{Principais inovações em relação aos recursos especial e extraordinário}

A despeito de não serem quantitativamente muitas, são significativas as mudanças que se pretende operar quanto aos recursos especial e extraordinário, principalmente quanto ao seu processamento e, mais uma vez, quanto à máxima efetividade que se pretende imprimir a esses recursos.

A primeira delas, digna de nota, é a novidade que traz a fungibilidade entre os recursos especial e extraordinário.

Assim, o art. 1.045 do Projeto do Novo CPC prevê que se o relator do recurso especial no STJ entender que a matéria envolve ofensa constitucional, intimará o recorrente para que, em 15 (quinze) dias, demonstre a existência de repercussão geral e se manifeste sobre a questão constitucional; então, remeterá o recurso ao STF, para que proceda ao exame de admissibilidade, sendo-lhe possível devolver o recurso ao $\mathrm{STJ}^{386}$.

De forma semelhante, o art. 1.046 do Projeto indica que se a ofensa à Constituição veiculada no recurso extraordinário for considerada meramente reflexa pelo relator, este o remeterá ao STJ, para que seja julgado como recurso especial ${ }^{387}$.

A doutrina que se debruçou sobre o tema tem se mostrado favorável à mudança, sobretudo porque se mostra positiva para, de uma vez por todas, resolver o problema do conflito negativo de atribuições ${ }^{388}$.

Outrossim, apoiada em uma lógica bivalente, como bem aponta MANCUSO ${ }^{389}$, evita-se a interposição simultânea, tal como ocorre nos dias atuais, de recursos especial e

\footnotetext{
386 "Art. 1.045. Se o relator, no Superior Tribunal de Justiça, entender que o recurso especial versa sobre questão constitucional, deverá conceder prazo de quinze dias para que o recorrente demonstre a existência de repercussão geral e se manifeste sobre a questão constitucional. Cumprida a diligência, remeterá o recurso ao Supremo Tribunal Federal, que, em juízo de admissibilidade, poderá devolvê-lo ao Superior Tribunal de Justiça".

387 "Art. 1.046. Se o Supremo Tribunal Federal considerar como reflexa a ofensa à Constituição afirmada no recurso extraordinário, por pressupor a revisão da interpretação da lei federal ou de tratado, remetê-lo-á ao Superior Tribunal de Justiça para julgamento como recurso especial”.

${ }^{388}$ CAMARGO, Luiz Henrique Volpe. A fungibilidade entre o recurso especial e o recurso extraordinário no Projeto do Novo CPC e a ofensa reflexa e frontal à Constituição Federal. In: ROSSI, Fernando et al. (coords). O futuro do processo civil no Brasil: uma análise crítica ao Projeto do Novo CPC. Belo Horizonte: Fórum, 2011, p. 417.
} 
extraordinário pelos causídicos, além de conferir-lhes maior segurança de que a omissão sobre determinado ponto não prejudicará o conhecimento dos demais.

Ademais, o art. 1.047 traz outra inovação considerável, na medida em que afirma que, uma vez admitido o recurso especial ou extraordinário por um fundamento, "devolve-se ao tribunal superior o conhecimento dos demais e de todas as questões relevantes para a solução do capítulo impugnado". Ou seja, isso significa que o âmbito de devolutividade dos recursos foi ampliado, porquanto permite aos tribunais superiores analisar os fundamentos da causa e da defesa, ainda que não suscitados no recurso.

O Projeto do Novo CPC também consagra o julgamento dos recursos extraordinário e especial repetitivos, assim entendidos como os recursos múltiplos que discutam idêntica questão de direito, tal como consta da subseção II ("Do julgamento dos recursos extraordinário e especial repetitivos”) da Seção II do Capítulo VI ("Dos recursos para o Supremo Tribunal Federal e para o Superior Tribunal de Justiça”) do Título II (Recursos) do Livro III da Parte Especial ${ }^{390}$.

A redação do art. 1.049 do Projeto é absolutamente assertiva: "sempre que houver multiplicidade de recursos com fundamento em idêntica questão de direito, o recurso extraordinário ou especial será afetado para julgamento”, ou seja, não se trata de mera faculdade, mas sim de verdadeiro mandamento legal.

Neste aspecto, a primeira inovação diz respeito à padronização do procedimento, eis que o tratamento dispensado tanto ao recurso especial como ao extraordinário foi unificado, o que é distinto da situação atual, na qual os recursos extraordinários repetitivos vêm disciplinados pelos arts. 543-A e 543-B, ao passo que os recursos especiais repetitivos o são por intermédio do art. 543-C do CPC.

\footnotetext{
${ }^{389}$ MANCUSO, Rodolfo de Camargo. A realidade brasileira e os tribunais da Federação - STF e STJ: inevitabilidade de elementos de contenção dos recursos a ele dirigidos. In: FUX, Luiz; NERY JR., Nelson; WAMBIER, Teresa Arruda Alvim. Processo e constituição: estudos em homenagem ao Professor José Carlos Barbosa Moreira. São Paulo: RT, 2006, p. 397.

390 "Art. 1.049. Sempre que houver multiplicidade de recursos com fundamento em idêntica questão de direito, o recurso extraordinário ou especial será afetado para julgamento de acordo com as disposições desta Subseção, observado o disposto no regimento interno do Supremo Tribunal Federal e do Superior Tribunal de Justiça”.
} 
Alguns traços desse capítulo merecem ter seu estudo aprofundado, mesmo porque há previsões inovadoras que, à primeira vista, parecem ser lacunosas.

Em primeiro lugar, o $\S 1^{\circ}$ do art. 1.049 determina que o presidente ou vice-presidente do tribunal de justiça ou do tribunal regional federal será responsável por selecionar dois recursos representativos da controvérsia e por encaminhá-los ao STF ou STJ "para fim de afetação", determinando a suspensão de todos os processos pendentes que tramitem no estado ou região.

Tal escolha, porém, não vincularará o relator do processo no Tribunal Superior, conforme aduz o $\S 4^{\circ}$, segundo o qual o relator poderá escolher outros recursos para representarem a controvérsia.

De todo modo, a possibilidade de suspensão dos recursos, tanto pelo presidente do tribunal a quo, como pelo Ministro relator no tribunal ad quem, já representa uma grande novidade, que, contudo, torna-se confusa à luz do que dispõe o $\$ 5^{\circ}$ do mesmo dispositivo: o Ministro relator na Corte superior poderá selecionar dois ou mais recursos "independentemente da iniciativa do presidente ou vice-presidente ou vice-presidente do tribunal de origem”.

É preciso aguardar como ocorrerá a regulamentação nos regimentos internos do STJ e do STF, mas parece-nos que a possibilidade de que os presidentes (ou vices) dos tribunais de origem selecionem recursos, e que os relatores em tribunal superior também o façam, pode representar um risco de duplo trabalho, mesmo porque o texto não fala quais recursos eleitos prevalecerão (presume-se que aqueles escolhidos pelos tribunais superiores), tampouco como ocorrerá a comunicação entre os órgãos judiciais. Assim, poder-se-á ter que lidar com situações em que o presidente do tribunal local ou regional seja comunicado da seleção dos recursos após já tê-lo feito, e vice-versa.

Quanto à forma de seleção, o texto não parece ter primado pela maior clareza ao falar que "somente podem ser selecionados recursos admissiveis que contenham abrangente argumentação e discussão a respeito da questão a ser decidida” ( $\$ 6^{\circ}$ do art. 1.049). Apreciar se dito recurso possui "abrangente argumentação e dicussão" a respeito da questão pode abrir espaço para o subjetivismo, mas há que se reconhecer que não é o recurso em si, eleito como paradigma, que mais importa, mas sim a tese que venha 
veiculada nele ou em outro recurso. O importante, pois, é dirimir as questões envolvendo a tese jurídica específica.

O art. 1.050, por sua vez, ilustra o que seja a citada "decisão de afetação", por meio da qual identificar-se-á, com precisão, a questão a ser submetida a julgamento; e sobrestar-se-ão todos os demais processos que versem sobre a qurestão no território nacional, pelo prazo máximo de um ano, período em que os recursos afetados deverão ter sido julgados.

Uma vez apreciada a tese jurídica após o julgamento do recurso excepcional representativo da controvérsia, seus efeitos atingirão todos os recursos sobrestados na origem, que (a) serão declarados prejudicados ou (b) serão decididos com base na tese fixada no(s) paradigma(s). É o que rezam os arts. 1.052 e 1.053, que impõem, conjuntamente, o seguinte:

(1) se o acórdão recorrido coincidir com a orientação do tribunal superior, seja negado seguimento aos recursos extraordinário ou especial;

(2) se o acórdão recorrido contrariar a novel orientação, o órgão que o proferiu reexaminará a causa;

(3) em ambas as hipóteses, os processos sobrestados em primeiro e segundo graus de jurisdição retomarão seu curso normal e a eles será aplicada a tese firmada pelo tribunal superior.

Aqui vemos outra novidade quanto aos efeitos procedimentais do julgamento, que atinge também o primeiro grau de jurisdição, imposição essa que é repetida no art. $1.054^{391}$, e é vista com bons olhos pela doutrina ${ }^{392}$.

Por derradeiro, preocupou-se a Comissão em claramente reduzir o acervo de processos, na medida em que fala, no $\S$ único do art. 1.052, que "negada a existência de repercussão geral no recurso extraordinário afetado e no representativo da controvérsia, serão considerados automaticamente inadmitidos os recursos extraordinários cujo processamento tenha sido sobrestado”.

391 “Art. 1.054. Sobrevindo, durante a suspensão dos processos, decisão da instância superior a respeito do mérito da controvérsia, o juiz proferirá sentença e aplicará a tese firmada”.

${ }^{392}$ MONNERAT, F. V. da F., op. cit., p. 196. 
Cabe breve menção a outra inovação pensada no Projeto do Novo CPC com relação especificamente ao capítulo que trata dos recursos especial e extraordinário, qual seja, aquela constante do art. 1.042, $\S 3^{\circ}$, que permite que o recurso tempestivo que for inadmitido por defeito formal, não reputado grave, tenha o mérito analisado pelo STJ e pelo STF, quando se tratar de casos repetitivos ou sempre que a decisão contribuir para o aperfeiçoamento do sistema jurídico ${ }^{393}$.

O artigo em comento, ao qual se voltará a mais adiante, é a mais fiel reprodução da atribuição da máxima efetividade a cada um dos processos. Vai, pois, ao encontro de muitas vozes que se insurgem, diuturnamente, contra as práticas cambaleantes e oscilantes das Cortes Superiores, cuja frequente mudança de posição traz total imprevisibilidade e insegurança jurídica.

Defeitos formais, a expressão em si já revela, são meramente atinentes à forma do recurso, e não ao seu conteúdo. E em atendimento ao princípio da instrumentalidade, desde há muito consagrado no nosso ordenamento, deve-se prestigiar o conteúdo em detrimento da forma, mesmo porque, sem sequer se dar conta, muitas vezes os Tribunais Superiores podem deixar de analisar e resolver uma quaestio juris de extrema relevância para a estabilidade jurisprudencial, sob o pálido argumento de que o recurso não reunia todas as suas condições formais.

Certamente os jurisdicionados esperam comedimento e razoabilidade dos Ministros, o que não lhes falta. Afinal, eliminar todos os requisitos formais representaria verdadeira chicana processual, e nenhum ordenamento sobrevive sem regras procedimentais formais. Fato é que, à luz da proporcionalidade, caberá aos guardiões da lei federal e da Constituição decidir, no caso concreto, o que se reputa como "vício formal grave". A tendência, ousamos vislumbrar, é a de serem editadas súmulas conforme os reiterados assuntos forem sendo submetidos ao crivo das Cortes Superiores.

\footnotetext{
393 “\$ $3^{\circ}$ O Supremo Tribunal Federal ou o Superior Tribunal de Justiça poderá desconsiderar vício formal de recurso tempestivo ou determinar sua correção, desde que não o repute grave”.
} 


\subsection{Fim da jurisprudência defensiva?}

Conforme a redação final aprovada pelo Senado, o Projeto do Novo CPC contribuirá para o aperfeiçoamento da prestação jurisidcional no Brasil sob o ângulo legal, pondo fim à chamada jurisprudência defensiva, cujos contornos vieram delimitados no Capítulo 4, bem como às principais hipóteses que a envolvem ${ }^{394}$, principalmente por intermédio da valorização das decisões paradigmáticas dos tribunais.

A questão da jurisprudência defensiva foi tratada geral e diretamente pelo legislador, que se preocupou em dotar o ordenamento de mecanismos que sirvam ao combate de tal prática $^{395}$.

Ao lado da valorização das decisões paradigmáticas dos tribunais, seja por meio da manutenção ou pela criação de novos mecanismos (como o incidente de resolução de demandas repetitivas), expediente considerado como uma das providências adotadas com a finalidade de acabar com a jurisprudência defensiva ${ }^{396}$, há vários dispositivos pontuais que adotam a mesma essência.

A começar, no âmbito recursal, pela previsão expressa de que o relator do recurso, antes de considerá-lo inadmissível, concederá (atenção para a forma imperativa do verbo) prazo de

\footnotetext{
${ }^{394}$ MONTEIRO, André Luis. Duas providências do Projeto de Novo Código de Processo Civil para o fim da chamada jurisprudência defensiva: uma evolução rumo ao pleno acesso à Justiça. Revista de Processo, ano 37, vol. 204, São Paulo: RT, fevereiro/2012, p. 267.

${ }^{395}$ Segue abaixo a transcrição que constou do Anteprojeto a respeito da tormentosa questão: "São criados instrumentos para combater a jurisprudência defensiva. Nessa linha, passa-se: (a) a admitir a regularização da representação processual junto aos Tribunais Superiores em contraposição ao disposto na Súmula 115 do STJ (art. 76); (b) a prever que o equívoco no preenchimento da guia de custas não resultará na aplicação da pena de deserção, cabendo ao relator, na hipótese de dúvida quanto ao recolhimento, intimar o recorrente para sanar o vício no prazo de cinco dias ou solicitar informações ao órgão arrecadador. Isso põe fim ao entendimento que se formou em relação à forma de recolhimento do preparo (ser ou não possível o pagamento pela internet) e ao preenchimento da guia (estar preenchida à mão ou no computador; conter ou não conter o número do processo, etc.) (art. 961, $\left.\$ 2^{\circ}\right)$; (c) a prever que se, ao julgar os embargos de declaração, o juiz, relator ou órgão colegiado não alterar a conclusão do julgamento anterior, o recurso principal interposto pela outra parte antes da publicação do resultado será processado e julgado independente de ratificação (art. 980, $\S 3^{\circ}$ ); (d) a admitir que a falta de peça obrigatória no agravo de instrumento não implicará a inadmissibilidade do recurso se o recorrente, intimado, vier a supri-la no prazo de cinco dias (art. 970, $\$ 3^{\circ}$ ). Além disso, há um dispositivo que, de maneira geral, permite que vícios formais sejam desconsiderados, pois, o que importa é que o mérito dos recursos seja efetivamente apreciado. Nesse sentido, o art. $983, \S 2^{\circ}$ prescreve que quando o recurso tempestivo contiver defeito formal que não se repute grave, o Superior Tribunal de Justiça ou Supremo Tribunal Federal poderão desconsiderar o vício, ou mandar saná-lo, julgando o mérito."

${ }^{396}$ MONTEIRO, A. L., op. cit., p. 273.
} 
5 (cinco) dias para que o recorrente sane o vício apontado ou complemente a documentação exigível ${ }^{397}$.

Alinhado a esta determinação, o Projeto repetiu a previsão com relação aos documentos necessários para a instrução dos agravos de instrumento. Desta feita, o $\S^{\circ}$ do art. 1.030 reza que, na falta da cópia de qualquer peça ou no caso de algum outro vício que comprometa a admissibilidade do recurso em testilha, o relator deve aplicar o disposto no $\S$ único do art. 945, ou seja, permitir a correção do vício.

Em todas essas previsões é possível entender que a lógica subjacente é o princípio da colaboração e/ou cooperação, porquanto o magistrado faz uso do seu dever de advertência com base no dever geral de prevenção, como apontam MARINONi e MitidiERo ${ }^{398}$.

Além da possibilidade de o mérito dos recursos especial e extraordinário ser enfrentado pelos Tribunais Superiores, como retratado no item anterior, ainda que o recurso contenha um defeito formal, outra dessas medidas voltadas a acabar, ou ao menos mitigar a dita jurisprudência defensiva, diz respeito à alteração referente ao prequestionamento do recurso especial no Projeto do Novo CPC.

Segundo o art. 1.038 do Projeto, “consideram-se incluídos no acórdão os elementos que o embargante pleiteou, para fins de prequestionamento, ainda que os embargos de declaração sejam inadmitidos ou rejeitados, caso o tribunal superior considere existentes erro, omissão, contradição ou obscuridade”, ou seja, o posicionamento adotado na redação se mostra consentâneo com a jurisprudência do STF (Súmula 356), mas representa inovação em relação ao STJ, sobretudo por modificar entendimento consagrado na Súmula $211^{399}$

397 “Art. 945. Incumbe ao relator: (...) Parágrafo único. Antes de considerar inadmissível o recurso, o relator concederá o prazo de cinco dias ao recorrente para que seja sanado vício ou complementada a documentação exigivel".

398 "Em atenção à colaboração que deve orientar a conduta do juiz com relação às partes no processo civil, o art. 301 do Projeto [na versão antiga] prevê dever geral de prevenção. Vale dizer: dever de o juiz avisar as partes de que o uso inadequado do processo pode colocar em risco o exame do direito material, impondolhe o dever de oportunizar aos litigantes a correção dos rumos de suas postulações”. (MARINONI, L. G.; MITIDIERO, D., op. cit., p. 112).

399 "Inadmissível recurso especial quanto à questão que, a despeito da oposição de embargos declaratórios, não foi apreciada pelo tribunal 'a quo'." 
A unificação do posicionamento, seguindo o STF, é vista como "a mais razoável, porquanto a adoção da posição do STJ, no caso de equívoco do tribunal a quo no julgamento de embargos de declaração, penalizaria a parte, pois nem sempre é possível a interposição de recurso especial, como por exemplo nos julgados de Turma Recursal dos Juizados Especiais e naqueles proferidos em embargos infringentes de alçada ",400.

Como demonstrado no capítulo precedente, o requisito do prequestionamento é tormentoso para os advogados e, destarte, para os jurisdicionados que eles representam em juízo.

Especificamente com relação aos aclaratórios, mesmo havendo súmula específica do STJ afirmando que embargos opostos com intuito de prequestionamento não têm efeito procrastinatório (Súmula 98), ainda assim há várias situações em que eles são considerados meramente procrastinatórios, razão pela qual o prequestionamento não é tido como realizado. Uma das facetas da chamada jurisprudência defensiva, pois, que ora se pretende mitigar.

Não obstante, a exigência de que seja obrigatoriamente declarado o voto vencido, que terá validade inclusive para fins de prequestionamento (art. 954, $\$ 3^{\circ 401}$ ), é uma inovação que afeta diretamente este instituto, auxiliando sua definição, bem como contribui para aumentar a economia e celeridade processuais ${ }^{402}$.

Adentrando especificamente os exemplos elencados na transcrição do Anteprojeto, o primeiro deles envolve a possibilidade de que seja sanado, em tempo razoável designado pelo órgão jurisdicional, vício de representação da parte ou incapacidade processual ${ }^{403}$, sem que isso imponha a liminar extinção do processo.

Quanto ao requisito do preparo, há um campo novo extremamente fértil, reproduzido no art. 1.020, que afasta o rigorismo formal que o caracteriza no sistema atual, aliado aos

\footnotetext{
${ }^{400}$ CARVALHO, Paulo Gustavo Medeiros. Recurso especial e recurso extraordinário. In: ROSSI, Fernando et al. (coords). O futuro do processo civil no Brasil: uma análise crítica ao Projeto do Novo CPC. Belo Horizonte: Fórum, 2011, p. 769.

401 " $\$ 3^{\circ} \mathrm{O}$ voto vencido será necessariamente declarado e considerado parte integrante do acórdão para todos os fins legais, inclusive de prequestionamento”.

${ }^{402}$ FARIA, M. C., op. cit., p. 285.

403 “Art. 76. Verificada a incapacidade processual ou a irregularidade da representação da parte, o órgão jurisdicional suspenderá o processo e designará prazo razoável para que seja sanado o vício”.
} 
óbices impostos pelos tribunais superiores, todos eles devidamente apontados no Capítulo 4.

Vamos às novidades.

O recorrente que não comprovar o recolhimento do preparo, no ato da interposição do recurso, será intimado para realizá-lo em dobro, sob pena de deserção $\left(\S 4^{\circ}\right)$. Trata-se de significativa novidade, porquanto o Código atual só permite a hipótese descrita no $\S 2^{\circ}$, que permite o recolhimento complementar do preparo quando o valor tiver sido recolhido a menor.

Além disso, o $\$ 6^{\circ}$ aduz que o relator do recurso poderá relevar a deserção se o recorrente provar justo impedimento, concedendo-lhe prazo de 5 (cinco) dias para efetuar o preparo $^{404}$. Trata-se da aplicação dos princípios da igualdade e da instrumentalidade, afinal o recolhimento do preparo, ainda que extemporâneo, cumpre seu mister.

Outro problema de importância curial para o tema - o preenchimento das guias de preparo - foi aparentemente resolvido no $\$ 7^{\circ}$, ao dizer que "o equívoco no preenchimento da guia de custas não implicará a aplicação da pena de deserção, cabendo ao relator, na hipótese de dúvida quanto ao recolhimento, intimar o recorrente para sanar o vício no prazo de cinco dias".

Na redação anteriormente sugerida, o relator podia intimar o órgão arrecadador a prestar esclarecimentos em caso de dúvida, mas talvez a mudança de texto tenha ocorrido em prol da maior celeridade, eis que a manifestação de tal órgão pode demorar e, portanto, atrasar o andamento do feito. Mais eficiente, então, que a parte recorrente preste diretamente os esclarecimentos necessários.

Tal previsão faz cair por terra várias das incertezas criadas pelas sucessivas resoluções editadas pelo STJ, conforme o recorte metodológico observado no Capítulo 4, bem como retira fundamento das decisões que, recorrentemente, deixam de analisar o mérito dos

404 “\$ $6^{\circ}$ Provando o recorrente justo impedimento, o relator relevará a pena de deserção, por decisão irrecorrível ,fixando-lhe prazo de cinco dias para efetuar o preparo”. 
recursos em virtude de questiúnculas meramente formais, tais como o preenchimento de guias à mão, sem chancela mecânica, entre outras.

Uma vez mais, a redação em comento dota de maior efetividade o processo e mostra uma das linhas mestras do Projeto, que é a prioridade dada ao julgamento do mérito dos recursos, tal como exposto logo na Exposição de Motivos.

Singela inovação é observada também quanto à necessidade de ratificação de determinados recursos excepcionais, tema este abordado no item 4.7 supra.

Vejamos o que dizem os $\S \S 3^{\circ}$ e $4^{\circ}$ do art. 1.036:

" $\S 3^{\circ}$ Caso o acolhimento dos embargos de declaração implique modificação da decisão embargada, o embargado que já tiver interposto outro recurso contra a decisão originária tem o direito de complementar ou alterar suas razões, nos exatos limites da modificação, no prazo de quinze dias, contados da intimação da decisão dos embargos de declaração".

" $\$ 4^{\circ}$ Se os embargos de declaração forem rejeitados ou não alterarem a conclusão do julgamento anterior, o recurso interposto pela outra parte, antes da publicação do julgamento dos embargos de declaração, será processado e julgado independentemente de ratificação".

A primeira hipótese trata dos embargos que tenham sido acolhidos com efeitos infringentes.

Nessa situação, o Projeto permite à parte embargada, que porventura já tenha interposto recurso especial e/ou extraordinário contra o acórdão recorrido, aditar suas razões recursais para complementá-las ou alterá-las, tendo em vista justamente os efeitos modificativos que o novo acórdão proferido em sede de embargos trouxe ao acórdão recorrido.

A previsão é extremamente positiva, visto que protege os princípios do contraditório e da ampla defesa, permitindo um julgamento mais seguro - e acertado - dos recursos excepcionais que foram interpostos.

Por outro lado, a previsão do $\S 4^{\circ}$ aborda o não acolhimento dos aclaratórios ou as hipóteses em que eles forem acolhidos sem efeitos infringentes (para correção de erro material, por exemplo). Em ambos os casos, o recurso que tenha sido interposto pela parte ex adversa antes da publicação do julgamento dos embargos de declaração (rectius, do acórdão), 
prescindirá de ratificação. A providência em comento, portanto, elimina mais uma hipótese qualificada como sendo manifestação de jurisprudência defensiva.

Por fim, quanto às outras hipóteses apontadas no Capítulo 4 como sendo casos de jurisprudência defensiva, o Projeto do Novo CPC mantém a necessidade de o recorrente dedicar uma parte específica de sua peça para demonstrar a existência da repercussão geral $^{405}$ e também diz ser irrecorrível a decisão que não reconhece a existência de repercussão geral a determinado recurso ${ }^{406}$.

\subsection{Considerações finais}

Os amplos e intensos debates que desaguaram na redação final do Projeto do Novo CPC mostram que a Comissão de Juristas partilha da maior preocupação balizadora da presente Dissertação, qual seja, de demonstrar a inequívoca tendência de o ordenamento pátrio, cada vez mais, valorizar os precedentes produzidos pelos nossos Tribunais Superiores.

Essa não é apenas um das tônicas do Projeto, mas representa, ousamos dizer, a linha mestra de todo o livro destinado a regular o processo no âmbito dos Tribunais Superiores, com importantes reflexos também para os graus inferiores de jurisdição.

Várias das medidas que estão em vias de ser adotadas tentam resgatar a máxima efetividade do processo, fato este que, além de ser recomendável, é um desiderato inclusive constitucional. Afinal, o acesso à Justiça, correlato à prestação jurisdicional justa, só é verdadeiramente alcançado quando o jurisdicionado é dotado de meios de persegui-la, quando possui título legítimo para tanto.

Após mais de 40 anos, o direito processual civil brasileiro se vê envolto a uma quaserevolução. Revolução sistêmica, revolução de ideias, mas, sobretudo, revolução de uma cultura jurídica que, historicamente muito pautada na fiel observância da lei, vê-se, paulatinamente, obrigada a se adaptar.

405 “Art. 1.047. Admitido o recurso extraordinário ou especial, o Supremo Tribunal Federal ou Superior Tribunal de Justiça julgará a causa, aplicando o direito. (...) $\$ 2^{\circ} O$ recorrente deverá demonstrar a existência da repercussão geral para apreciação exclusiva do Supremo Tribunal Federal”.

406 "Art. 1.047. Admitido o recurso extraordinário ou especial, o Supremo Tribunal Federal ou Superior Tribunal de Justiça julgará a causa, aplicando o direito. (...) $\$ 8^{\circ}$ Negada a repercussão geral, o presidente ou vice-presidente do tribunal de origem negará seguimento aos recursos extraordinários sobrestados na origem que versem sobre matéria idêntica”. 
Adapta-se, ou morre. Não há como negar o intenso movimento desde a década de $90 \mathrm{em}$ prol da valorização do direito jurisprudencial, caracterizado por inúmeras minirreformas. $\mathrm{O}$ que a Comissão de Juristas faz, agora, é dar seguimento a elas, em meio a um texto mais coeso e harmônico, indo ao encontro das muitas críticas que vinham sendo tecidas ao CPC atual por mais se parecer uma "colcha de retalhos" após as sucessivas mudanças pontuais. Além de ver refletidas no Projeto muitas das premissas nas quais este trabalho se assentou, parece-nos ser tão auspiciosa quanto a necessária valorização da figura do precedente a tentativa de extirpar da nossa prática jurídica nos tribunais a chamada jurisprudência defensiva.

Vários dispositivos têm o condão de, se não acabar por completo com essa prática, minimizá-la significativamente, sendo um deles aquele que trata da fungibilidade entre os recursos especial e extraordinário, facilitando a vida dos recorrentes e mitigando, destarte, as áridas questões relativas à ofensa reflexa à Constituição, por exemplo.

Entretanto, a nosso ver, nem tudo é positivo no Projeto, e nem poderia ser, afinal sempre haverá espaço para aprimoramentos. Há que se pensar em uma problemática que foi abordada na introdução da presente Dissertação, e que ensejou a própria criação dessas formas de autodefesa pelos tribunais, que é justamente o excessivo volume de processos a serem julgados.

As medidas propostas, claramente, privilegiam o acesso à Justiça, princípio constitucional que é de sabença geral. Ao privilegiar a análise do mérito recursal em detrimento de seus aspectos formais em determinadas hipóteses, está-se tutelando o direito legítimo daqueles que veem no Judiciário a última esperança para a resolução de seus problemas.

Por outro lado, ao valorizar os precedentes como um todo, e alçá-los a uma condição de importância talvez nunca antes experimentada no direito brasileiro, o legislador mostra sua preocupação em resolver, rapidamente, os conflitos repetitivos e/ou massificados, o que, a um só tempo, aumenta a estabilidade e uniformidade jurisprudenciais e abre espaço para o julgamento, nas Cortes superiores, de matérias de suma relevância do ponto de vista legal e constitucional. 
Entretanto, somente o tempo (e a práxis forense) irá dizer se o aumento da tramitação e o volume maior de recursos que chegarão aos Tribunais Superiores serão compensados pelas técnicas de coletivização dos julgamentos, caso v.g. do incidente de resolução de demandas repetitivas, ajudando a reduzir a problemática atual ou se, infelizmente, ela acabará sendo acentuada.

A equação - com as respectivas variáveis - está posta na mesa há mais de duas décadas; ao que parece, o legislador pretende mexer em ambas simultaneamente, o que certamente é um risco.

Mas decerto é melhor correr esse risco beneficiando uma ordem jurídica mais justa, ainda que mais morosa, mesmo porque para o problema da morosidade é possível melhorar a infraestrutura judiciária, dotando-a de mais juízes, desembargadores, ministros, etc. Já para o problema da incorreção (ou injustiça) das decisões, nada há a socorrer os desafortunados, a não ser o aumento por via oblíqua do congestionamento dos tribunais (mediante recursos, ações rescisórias, entre outros). 


\section{SÍNTESE CONCLUSIVA}

É lugar-comum entre os operadores do direito no Brasil, inclusive entre aqueles que ocupam os mais altos cargos na hierarquia judiciária brasileira, a constatação de que as nossas Cortes Superiores, assim constitucionalmente eleitas, não têm desempenhado satisfatoriamente a missão institucional que lhes foi designada.

E isso ocorre, de longa data, muito mais por um problema estrutural e fisiológico do que por uma suposta deficiência na prestação da tutela jurisdicional. Muito pelo contrário, afinal quando os Tribunais Superiores efetivamente se deparam com o julgamento de determinada matéria controvertida, o pronunciamento é altamente elucidativo e profícuo para os jurisdicionados, atendendo ao desiderato uniformizador.

Problemas de várias ordens acometem e afligem aqueles que precisam se socorrer do Poder Judiciário brasileiro. Morosidade e ineficiência, gerando insegurança jurídica, são apenas alguns deles, mas tão significativos a ponto de fazerem muitos estudiosos se debruçarem sobre as razões que levaram a este panorama caótico, dentre eles o Ministro Luis Roberto Barroso, do STF, um dos expoentes a lutar por mudanças naquela Corte.

O que se pretendeu demonstrar, por meio desta Dissertação, é que a plena compreensão do panorama atual exige duas reflexões: uma sob a perspectiva histórica, e outra sob a ótica do direito comparado.

O perfil histórico permitiu entender qual a origem das nossas Cortes Superiores e da espécie de pronunciamento que delas advêm; de outro lado, o método comparativo possibilitou a melhor compreensão acerca da solução proposta pelo legislador brasileiro, há mais de duas décadas, e que vem sendo colocada em prática desde então, qual seja, a utilização de institutos até então alheios à nossa tradição jurídica, oriundos das famílias que aderiram ao common law e que denotam a preocupação com a uniformização jurisprudencial e, ao mesmo tempo, com a valorização dos precedentes como forma de atingi-la, sobretudo daqueles dotados de eficácia vinculante. 
Com isso, ainda que por via oblíqua, o legislador pretendeu desafogar os Tribunais Superiores, diversificando os instrumentos disponibilizados aos magistrados, sobretudo àqueles de segundo grau e aos Ministros.

Partindo da retrospectiva histórica, é impensável tecer quaisquer considerações sem estudar o direito peninsular ibérico, em especial o português, nosso antecedente remoto - e direto, inclusive para fins jurisprudenciais - até pouco mais de um século atrás.

Assim é que, desde a recepção do direito comum na península ibérica, os precedentes têm participação intensa na vida portuguesa, em um movimento pendular de adoção de precedentes com e sem efeito vinculativo.

Neste contexto é que foram estudados os institutos das façanhas, dos estilos e dos assentos da Casa da Suplicação lusitana, com maior destaque dado aos últimos, porquanto, enquanto vigentes no ordenamento português (mais precisamente até 1993), a decisão neles consubstanciada tinha força de lei e se prestava, ao mesmo tempo, a dirimir e pacificar os conflitos. Modernamente, aproximam-se das súmulas, tão arraigadas em nossa cultura jurídica.

De toda sorte, a conclusão subjacente a este específico período histórico gira em torno da existência dos precedentes, e com denotada relevância, mesmo em um sistema altamente codificado como o português.

Essas premissas pavimentaram o caminho para demonstrar que o movimento brasileiro não é isolado no âmbito do civil law. Ao contrário, sistemas tradicionais como França, Itália e Alemanha, representantes tanto dos sistemas de cassação como de revisão, também fizeram e fazem uso dos precedentes, em maior ou menor escala, sempre tendo em mente, frise-se, a uniformização da aplicação do direito.

Em todos esses sistemas brevemente estudados, percebe-se a familiaridade com os precedentes com eficácia relativamente persuasiva. Ou seja, ainda que não sejam, por força de lei, vinculantes, sua reiterada aplicação, principalmente em matérias constitucionais, acaba por dotá-los de força maior do que meramente persuasão para os julgamentos futuros. 
Chegou-se, ato contínuo, ao common law. Aí sim residem as substanciais diferenças em relação ao civil law. E, da mesma maneira que tais diferenças existem, elas têm sido atenuadas nos últimos tempos. Expliquemo-nos em seguida.

Paralelamente às diferenças, seu estudo, tão profícuo para entender o movimento estrutural que o Brasil tem vivido desde os anos 90, revela-se ainda mais indispensável quando se recorda que toda a sistemática do nosso recurso extraordinário foi pensada a partir do writ of error norte-americano.

Pois bem. Diante disso, procurou-se abordar a gênese dos órgãos judiciais superiores da Inglaterra e dos EUA, ordenamentos eleitos para representar a análise acerca da família que é adepta do "direito comum" e que pouca influência recebeu do direito romano, a começar pela Inglaterra, cujas dificuldades geográficas contribuíram, em grande medida, para impedir a penetração do ius commune justinianeu.

A doutrina do stare decisis, e, portanto, do binding precedent, é fulcral para explicar qual a importância que os precedentes desfrutam, até hoje, nos ordenamentos citados. Apesar de integrantes da mesma família jurídica, e de os EUA terem sido moldados à feição dos costumes ingleses em virtude da colonização, há diferenças significativas tanto estruturais como na forma de julgamento entre os dois países.

Procurou-se demonstrar, pois, que a extração da ratio decidendi é o que importa para fins da uniformização jurisprudencial, ou seja, os precedentes com eficácia vinculativa o são porque é a ratio decidendi que se projeta para os casos futuros.

Ademais, a influência da common law sobre o direito brasileiro vai muito além do que a mera sistemática do recurso extraordinário. A começar pela criação das súmulas vinculantes, em 2004, que representou uma inequívoca sinalização no sentido de que a teoria dos binding precedents passaria a ser utilizada pela nossa Corte Suprema.

Ademais, é certo que a Suprema Corte americana efetivamente escolhe quais casos deseja julgar, certificando, portanto, a relevância de determinada questão (daí o writ of certiorari). O mesmo aconteceu, no Brasil, desde a implementação da exigência da demonstração da 
repercussão geral como mais um requisito intrínseco de admissibilidade do recurso extraordinário, que, caso inexistente, gera o não conhecimento do recurso.

Em ambos os casos, mais uma sinonímia: tanto a Suprema Corte americana como a brasileira se viram atoladas e assoberbadas em meio a tantos recursos pendentes de julgamento. Decidiram, então, restringir o acesso dos jurisdicionados a elas, selecionando quais matérias deseja julgar.

Subsequentemente às similitudes (e também diferenças) apontadas, passou-se a adentrar especificamente o modelo brasileiro, que também teve momentos históricos em que os precedentes oscilaram, ora a ocupar maior espaço, ora menor.

A exposição em torno do funcionamento e criação das Cortes Superiores em outros ordenamentos de civil law serviram para explicitar que o constituinte, ao criar o STJ em 1988, buscou segregar as competências do STF para relegá-lo ao papel de verdadeira Corte Constitucional, deixando para o novo tribunal a competência para análise das violações perpetradas à legislação infraconstitucional. Tal mister, como visto, existe tanto na Itália como na Alemanha.

Fazendo nova interface com o raio-x que se esquadrinhou no capítulo 1 quanto aos principais entraves para a efetiva prestação da tutela jurisdicional nos Tribunais Superiores brasileiros, a segregação da competência do STF foi a forma colocada em prática para tentar reduzir a quantidade de processos a serem julgados.

Passadas quase três décadas desde a criação do STJ, porém, estudos encabeçados pela Fundação Getúlio Vargas, que destrincharam o perfil da nossa Suprema Corte, demonstram e comprovam que ela é muito mais uma Corte recursal do que constitucional, e o maior responsável pela avalanche recursal é, ironicamente, o próprio Poder Público.

A criação dos já citados mecanismos da repercussão geral e da súmula vinculante contribuíram, em parte, para mitigar o problema, mas a curva continua ascendente no que se refere à fila de julgamento. 
O problema maior, portanto, está posto. E há muito tempo. Ao lado dessas medidas, várias outras minirreformas foram empreendidas no CPC pátrio desde o início de 1990, sendo uma delas consistente no aumento do poder atribuído aos relatores dos recursos de apelação, que podem julgá-los monocraticamente quando estiverem em confronto com súmula do STJ e do STF, mesmo que não vinculante, consistindo na chamada súmula impeditiva de recursos.

A partir desses exemplos, foi possível observar perfeitamente os dois objetivos delineados pelo legislador: valorizar o direito jurisprudencial dentre as fontes de direito brasileiras e, em paralelo, utilizá-la como escudo para tentar dotar os Tribunais Superiores de capacidade para prestar a tutela jurisdicional, em última instância e ou única instância, que é o que deles se espera.

Porém, tais reformas foram pontuais, e não sistêmicas. Tentou-se, ademais, enfatizar técnicas de coletivização dos julgamentos, por intermédio do julgamento dos recursos repetitivos, através dos quais a decisão posta para o recurso eleito como paradigma é replicada para os demais.

Aqui, entretanto, merece uma pequena digressão. Foi tema desta Dissertação conceituar o precedente, tanto sob a ótica do direito comparado como sob a visão do direito brasileiro. Em linhas gerais, embasa a noção de precedente a ideia de que a decisão nele contida tem aptidão de se protrair no tempo e influenciar julgamentos futuros.

Ocorre, entretanto, que no common law é a ratio decidendi que forma o precedente, ao passo que no Brasil é a parte dispositiva do acórdão que se presta à nova utilização futura.

Assim, tais nuances podem representar um certo perigo à segurança jurídica no caso brasileiro, porquanto a mera importação de uma técnica alheia à nossa tradição não pode ocorrer automaticamente; merece, sim, uma reflexão mais aprofundada, sob pena de se aplicar o mesmo precedente para casos cujos fatos eram diferentes, o que em tese pode alterar a conclusão do julgado.

Destarte, a análise da interpretação dos precedentes, e eleição dos paradigmas, deve ser mais criteriosa, em que pese corresponder a uma tutela jurisdicional mais morosa. Mas aí 
estão em jogo dois valores essenciais, sendo que um deve, inexoravelmente, se sobrepor ao outro.

Outra ressalva que deve ser feita diz respeito ao confronto entre a estabilidade do direito e sua imutabilidade. As palavras não são sinônimas, e apenas o primeiro objetivo deve ser perseguido, sobretudo porque mesmo os ordenamentos anglo-saxões convivem, hodiernamente, com a possibilidade de modificação das decisões proferidas por seus Tribunais Superiores, que não ficam engessados quando as circunstâncias assim o exigir, valendo-se do instituto do overruling, em suas variadas vertentes. Nada mais justo, lógico e coerente.

Feito esse aparte, voltemos às inovações carreadas por meio da EC 45/04, que, muito embora tenha recebido a alcunha de "reforma do Judiciário", infelizmente não conseguiu resolver todos os obstáculos com os quais os jurisdicionados têm que lidar.

Mas isso não retira sua importância, muito pelo contrário. A emenda traduziu, para o direito positivo, muitas dessas mudanças que demonstram a aproximação com a common law e subsequente valorização do direito jurisprudencial traduzido pelos precedentes, tendo afetado, inclusive, a própria sistemática dos recursos especial e extraordinário, recursos de fundamentação vinculada que se situam no topo da hierarquia recursal e que foram lá cuidadosamente colocados diante da função constitucional dos nossos Tribunais Superiores.

E mais: justamente pela análise evolutiva dos temas, acreditamos que essa tendência é inafastável e um caminho sem volta.

Trata-se de um híbrido entre os dois sistemas que é extremamente salutar, desde que não represente uma ruptura completa das tradições jurídicas de um país e, principalmente, que sejam importados institutos com comprovada eficácia no direito estrangeiro, ainda que isso não seja garantia de sucesso em solo brasileiro, pelas especificidades inerentes a cada ordenamento.

Desta feita, as mudanças, isolada ou coletivamente analisadas, representaram uma alteração paradigmática estrutural do nosso ordenamento jurídico, que, motivada pela 
impossibilidade fisiológica de se estancar a sangria de infindáveis recursos aguardando julgamento, caminha, a passos largos, para transformar o direito jurisprudencial em fonte do direito quase tão importante quanto a lei.

Mesmo após a implementação do processo eletrônico e do julgamento virtual no âmbito dos tribunais, a reforma se mostra incompleta e insatisfatória, o que também é lugarcomum entre os operadores do direito. Chegamos a um novo ponto de estrangulamento, que exige a adoção de medidas outras para combater o quadro de permanente perda de eficiência.

Assistematicamente, têm sido pensadas medidas como a extensão da repercussão geral para os recursos especiais; a criação de novos Tribunais Regionais Federais; e mudanças regimentais no STF, envolvendo a alteração da competência para julgamento do Pleno e das Turmas, por exemplo.

Sem entrar no mérito da validade de cada uma elas, que já foi explorado ao longo deste trabalho, ainda assim elas se afiguram incapazes, de per si, de resolver todos os entraves do sistema processual civil brasileiro.

Eis, então, que a discussão não poderia ser mais atual quando estamos em vias de, finalmente, aprovar um novo Código de Processo Civil em substituição ao atual, vigente há mais de quarenta anos.

Após mais de quatro anos de tramitação no Congresso Nacional, com idas e vindas na Câmara e no Senado, onde tudo começou por meio do PLS n. ${ }^{\circ}$ 166/2010, a redação final aguarda apenas a sanção presidencial, o que decerto impacta e reflete em praticamente todos os temas aqui tratados.

Há que se ter em mente, porém, que as tentativas de aprimorar o sistema devem ser perquiridas sempre à luz dos direitos e garantias fundamentais, ocasionando uma reforma democrática e eficiente, de tal maneira que se possa, efetivamente, conferir celeridade à tramitação dos feitos e evitar a descabida repetição dos mesmos, o que acabaria por aliviar tanto a Justiça de primeira e segunda instâncias como os próprios tribunais superiores. 
Nessa seara reside a temática específica da jurisprudência defensiva, que foi devidamente conceituada e exemplificada no presente trabalho, e cuja relevância é constatada desde a definição de seu conceito, qual seja, a criação e utilização de requisitos formais dos recursos que obstem o acesso às Cortes Superiores, em clara prejudicialidade do enfrentamento do mérito recursal.

Tais práticas são objeto de inúmeros reclamos da comunidade jurídica, seja no que tange aos requisitos que não possuem amparo legal - caso das guias de preparo - seja, ainda, no desvirtuamento da aplicação de súmulas consagradas tanto do STJ como do STF.

Que é preciso restringir o acesso ao STJ e ao STF, para que cumpram o perfil nomofilático que lhes foi constitucionalmente atribuído, disso não discordamos. Discordamos, entretanto, da implementação de medidas ao arrepio da lei, da segurança jurídica e de outras garantias fundamentais, algumas das quais sem justificativa razoável.

Esse não é o caminho a ser seguido, mesmo porque o contingente recursal, à primeira vista, é reduzido quantitativamente, mas não qualitativamente, que é o que se sustenta a longo prazo. Os demais mecanismos, que funcionam como verdadeiros filtros recursais, são plenamente válidos, legítimos e, sobretudo, imprescindíveis, mesmo porque em um País de dimensões quase continentais como o brasileiro, faz-se mister criar métodos de aplicação uniforme da lei e das decisões em todo o território, ainda mais porque incontáveis demandas veiculam teses jurídicas idênticas.

Felizmente, tais desvios de finalidade, conquanto sejam usuais em percursos que têm mudanças abruptas, não passaram despercebidos pela Comissão de Juristas designada para pensar o texto do novo Código de Processo Civil.

De todas as futuras novidades que foram minudentemente exploradas neste Trabalho, a mens legis que fica é: o direito jurisprudencial será ainda mais valorizado, os mecanismos já existentes serão aprimorados, e outros novos serão criados, caso, v.g., do incidente de resolução de demandas repetitivas.

Atrelado a isso, pretende-se pôr fim a quase todas as práticas qualificadas como integrantes da jurisprudência defensiva, afinal reitera-se que a criação de requisitos formais para o não 
conhecimento dos recursos de sobreposição não é, de longe, a panacéia para a crise brasileira quanto ao excessivo volume de processos aguardando julgamento.

À primeira vista, a impressão que ficou com relação ao Projeto do Novo CPC é extremamente positiva.

Um capítulo foi inteiramente dedicado a regular os precedentes, houve mudança na sistemática recursal, tentativa de simplificar o procedimento e, outrossim, desejo explícito de retomar o princípio da instrumentalidade a ponto de valorizar, ao máximo, o mérito recursal, fazendo cair por terra o formalismo exacerbado que é, até então, tônica da jurisprudência defensiva.

Não se sabe como a práxis forense irá reagir às novidades, mas o simples fato de o legislador insistir nessa mudança cultural se revela paradigmática para vislumbrar os rumos que o processo civil brasileiro pretende adotar, ao menos nas próximas décadas.

Percebe-se, com absoluta certeza, que o direito positivo, de per si, não é capaz de solucionar e atender aos anseios de uma comunidade jurídica quantitativamente milionária, em especial se se pensar no Poder Legislativo pátrio, cuja crise moral - e produtiva - é muito mais duradoura, e acentuada, do que aquela vista no Judiciário, que justamente por isso é, muitas vezes, chamado a suprir lacunas legislativas.

Erigir o direito jurisprudencial à condição de fonte do direito, se não superior, mas pelo menos em pé de igualdade com a lei, significa, a nosso ver, importar do direito anglo-saxão um modelo que apresenta mais virtudes do que vicissitudes.

Naturalmente, o êxito prolongado deste mister dependerá do saneamento de óbices que representaram o desvirtuamento do modelo quando foram aplicados aqui no Brasil, e que foram devidamente anotados nesta Dissertação, mas em um mundo ideal e utópico, focado apenas nos aspectos jurídicos que comparam o civil law e o common law, estamos alinhados aos juristas que entendem ser descabida a separação estanque entre tais modelos, sendo desejável a confluência entre ambos, incorporando aspectos de um ou de outro, a depender do ordenamento com o qual se estiver lidando. 
Espera-se, de maneira geral, que as considerações aqui expostas tenham contribuído para jogar luz sobre diversos temas tão candentes, necessários e atuais, que por certo serão objeto de estudo nos anos vindouros, sobretudo sob a égide do novo Codex processual brasileiro, que realisticamente falando não terá o condão de acalentar todas as angústias dos processualistas nacionais, mas ao menos trará infinitos novos temas para debates e reflexões. 


\section{REFERÊNCIAS BIBLIOGRÁFICAS}

\section{I) Livros}

ABRAMOVICZ, Michael; STEARNS, Maxwell. Defining dicta. Stanford Law Review, mar./2005.

ALEXY, Robert. Teoria da argumentação jurídica, trad. de Zilda Hutchinson Schild Silva. São Paulo: Landy, 2001.

ANDREWS, Neil. A Suprema Corte do Reino Unido: reflexões sobre o papel da mais alta Corte britânica. Revista de Processo n. ${ }^{\circ}$ 186, ano 35, ago./2010.

ARAÚJO, José Henrique Mouta. Processos repetitivos e o novo CPC: ampliação do caráter vinculante das decisões judiciais. In: ROSSI, Fernando et al. (coords). O futuro do processo civil no Brasil: uma análise crítica ao Projeto do Novo CPC. Belo Horizonte: Fórum, 2011.

ARMELIN, Donaldo. Uma visão da crise atual do Poder Judiciário. In: MACHADO, Fábio Cardoso; MACHADO, Rafael Bicca (coords.). A reforma do Poder Judiciário. São Paulo: Quartier Latin, 2006.

ARON, Raymond. Les institutions politiques de l'Occident dans le monde du XX siècle. In: Colloques de Berlin, La democratie a l'epreuve du XX siecle. Paris: Calmann-Levy, 1960.

ALVIM, Arruda. O antigo recurso extraordinário e o recurso especial (na Constituição Federal de 1988). In: TEIXEIRA, Sálvio de Figueiredo (coord.). Recursos no Superior Tribunal de Justiça. São Paulo: Saraiva, 1991.

. Notas sobre o Projeto de novo Código de Processo Civil. In: WAMBIER,

Luiz Rodrigues; WAMBIER, Teresa Arruda Alvim (coords). Doutrinas essenciais: Processo Civil, vol. I. São Paulo: RT, 2011.

ASSIS, Araken de. Manual dos recursos. $1^{\mathrm{a}}$ ed. São Paulo: Revista dos Tribunais. 2007. 
ATHENIENSE, Aristóteles. A jurisprudência defensiva do STJ e sua inconveniência. In: SILVA, José Anchieta (org.). O novo processo civil. São Paulo: Lex Editora, 2012.

Banco Internacional de Reconstrução e Desenvolvimento - Banco Mundial. O Estado num mundo de transformação. Washington, 1997. Disponível [online] em http://www.acervo.epsjv.fiocruz.br/beb/textocompleto/mfn11116.

BARBOSA MOREIRA, José Carlos. Notas sobre alguns aspectos do processo (civil e penal) nos países anglo-saxônicos. In: Temas de Direito Processual, $7^{\text {a }}$ série. São Paulo: Saraiva, 2001.

Janeiro: Forense, Volume V, 2005.

Comentários ao Código de Processo Civil. Rio de . Restrições ilegítimas ao conhecimento dos recursos.

In: Temas de Direito Processual, 9a série. São Paulo: Saraiva, 2007.

O poder da Suprema Corte norte-americana e suas limitações. Revista Magister de Direito Civil e Processual Civil n. ${ }^{\circ}$ 23, ano IV, mar.abr./2008.

BAUM, Lawrence. A Suprema Corte americana, trad. de Élcio Cerqueira. Rio de Janeiro: Forense Universitária, 1987.

BLACKSTONE, William. Commentaries on the Laws of England, $9^{\text {th }}$ ed. London: Cavendish, 2001.

BRAGHITTONI, Rogério Ives. Uniformização de jurisprudência e art. 555, $1^{\circ}$, do Código de Processo Civil. Revista do Instituto dos Advogados de São Paulo n. ${ }^{\circ} 15$, ano 8, jan.-jun/2005.

Recurso extraordinário: uma análise do acesso do Supremo Tribunal Federal. São Paulo: Atlas, 2007. 
BRENNER, Saul; SPAETH, Harold J. Stare Indecisis: the alteration of precedent on the Supreme Court. New York: Cambridge University Press, 1995.

BUENO, Cássio Scarpinella. Curso sistematizado de direito processual civil, v. 5. São Paulo: Saraiva, 2008.

Paulo: Saraiva: 2009.

. Curso sistematizado de direito processual civil, v. 9. São

BURNHAM, William. Introduction to the law and legal system of the United States. St. Paul, MN: Thomson West, 2006.

CALVANO, Roberta. Lo stare decisis nella più recente giurisprudenza della corte costituzionale. Giurisprudenza costituzionale, n. 2, ano XLI, Milano: Cedam, mar.abr./1996.

CAMARGO, Luiz Henrique Volpe. A fungibilidade entre o recurso especial e o recurso extraordinário no Projeto do Novo CPC e a ofensa reflexa e frontal à Constituição Federal. In: ROSSI, Fernando et al. (coords). O futuro do processo civil no Brasil: uma análise crítica ao Projeto do Novo CPC. Belo Horizonte: Fórum, 2011.

CAMPOS MELLO, Patrícia Perrone. Precedentes. Rio de Janeiro: Renovar, 2008.

CANOTILHO, José Joaquim Gomes. Direito constitucional e teoria da Constituição. Coimbra: Almedina, 2000.

CAPPELlETTI, Mauro; GARTH, Bryant. Acesso à justiça, trad. de Ellen Gracie Northfleet. Porto Alegre: Sergio Fabris Editor, 1988.

CAPPELLETTI, Mauro. Dimensioni della giustizia nelle società contemporanee: studi di diritto giudiziario comparato. Bologna: Il Mulino, 1994.

CARVALHO, Paulo Gustavo Medeiros. Recurso especial e recurso extraordinário. In: ROSSI, Fernando et al. (coords). O futuro do processo civil no Brasil: uma análise crítica ao Projeto do Novo CPC. Belo Horizonte: Fórum, 2011. 
CINTRA, Antonio Carlos de Araújo; GRINOVER, Ada Pellegrini; DINAMARCO, Cândido Rangel. Teoria geral do processo, 23ª ed. São Paulo: Malheiros, 2007.

CIUFFO, Diogo Carneiro. Os requisitos de admissibilidade dos recursos especial e extraordinário e a sua ilegítima utilização como filtros recursais. Revista de Processo, vol. 160, São Paulo: RT, 2008.

COLE, Charles D. Precedente judicial: a experiência americana. Revista de Processo n. ${ }^{\circ}$ 92, ano 23, out.-dez./1998.

COSTA, Mário Júlio de Almeida. História do direito português. $3^{\mathrm{a}}$ ed. Coimbra: Almedina, 2000.

COUTINHO, Luciano. Risco Brasil, Risco do Brasil. Folha de S. Paulo de 10.10.1999.

CRUZ, Guilherme Braga da. História do direito português (publicação devidamente autorizada das lições proferidas ao $1^{\circ}$ ano jurídico 55-56 pelo Exmo. Sr. Prof. Doutor Braga da Cruz; coligidas por A. Barbosa de Melo). Coimbra, 1955.

O direito subsidiário na história do direito português.

Separata da Revista portuguêsa de história: Coimbra, 1975.

DAVID, René. Os grandes sistemas do direito contemporâneo. $4^{\mathrm{a}}$ ed. São Paulo: Martins Fontes, 2002.

DELGADO, José Augusto. Reforma do Poder Judiciário: Art. 5o, LXXVIII, da CF. In: WAMBIER, Teresa Arruda Alvim; WAMBIER, Luiz Rodrigues et al. (coords.). Reforma do Judiciário: primeiras reflexões sobre a Emenda Constitucional n. 45/2004. São Paulo: Revista dos Tribunais, 2005.

DIDIER JR., Fredie; BRAGA, Paula Sarno; OLIVEIRA, Rafael. Curso de direito processual civil, vol. II. $5^{\mathrm{a}}$ ed. Salvador: JusPodvum, 2010.

DINAMARCO, Cândido Rangel. Superior Tribunal de Justiça e acesso à ordem jurídica justa. Revista de Processo n. ${ }^{\circ}$ 59, São Paulo: RT, ju.-set./1990. 
A reforma da reforma, $6^{\mathrm{a}}$ ed. São Paulo: Malheiros, 2003.

Tempestividade dos recursos. Revista Dialética de Direito

Processua, n. ${ }^{\circ}$ 16, São Paulo, jul./2004.

. Súmulas vinculantes. Revista Forense n. ${ }^{\circ}$ 347, v. 95, Rio

de Janeiro, 1999.

DUXBURY, Neil. The nature and authority of precedent, Camdrige: Cambridge University Press, 2008.

DWORKIN, Ronald. Taking rights seriously, Cambridge: Oxford University Press, 1978.

ELIAS, Carlos Eduardo Stefen. Os fundamentos da estrutura do sistema recursal no Código de Processo Civil de 1973 e no Projeto de novo Código de Processo Civil. In: JUNIOR, Nelson Nery; WAMBIER, Teresa Arruda Alvim (coords.). Aspectos polêmicos e atuais dos recursos cíveis e assuntos afins, v. 12. São Paulo: RT, 2011.

FALCÃO, Joaquim; CERDEIRA, Pablo de Camargo; ARGUELHES, Diego Werneck. I Relatório Supremo em Números - Múltiplo Supremo. Rio de Janeiro: FGV, 2011, disponível em www.supremoemnumeros.fgv.br.

FALCÃO, Joaquim; HARTMANN, Ivar A.; CHAVES, Vitor P. III Relatório Supremo em Números: O Supremo e o tempo. FGV Direito Rio: Rio de Janeiro, 2014, disponível em www.supremoemnumeros.fgv.br.

FARIA, Márcio Carvalho. A jurisprudência defensiva dos tribunais superiores e a ratificação necessária (?) de alguns recursos excepcionais. Revista de Processo n. ${ }^{\circ}$ 167, ano 34 , jan./2009.

O formalismo exacerbado quanto ao preenchimento das guias de preparo: ainda a jurisprudência defensiva dos tribunais superiores. Revista de Processo n. ${ }^{\circ}$ 193, ano 36, mar./2011.

O novo Código de Processo Civil vs. a jurisprudência defensiva. Revista de Processo n. ${ }^{\circ}$ 210, ano 37, agosto/2012. 
FARINA, Fernanda Mercier Querido. Jurisprudência defensiva e a função dos Tribunais Superiores. Revista de Processo n. ${ }^{\circ}$ 209, ano 37, jul./2012.

FERNANDES, Tarsila Ribeiro Marques. A influência da common law na teoria do precedente vinculante no ordenamento jurídico brasileiro. In: Publicações da Escola da AGU. $2^{\circ}$ Curso de Introdução ao Direito Americano: Fundamentals of US Law Course. Brasília: Escola da Advocacia-Geral da União, ano IV, n. ${ }^{\circ}$ 16, v. 2, abril/2012.

FONSECA, Rodrigo Garcia da. O papel do Supremo Tribunal Federal e a Repercussão Geral no Recurso Extraordinário. In: MARTINS, Ives Gandra da Silva; JOBIM, Eduardo (coords.). O processo na Constituição. São Paulo: Quartier Latin, 2008.

FUX, Luiz. A súmula vinculante e o Superior Tribunal de Justiça. Revista de Direito Bancário e do Mercado de Capitais, ano 8, n. ${ }^{\circ}$ 28, abr.-jun. 2005.

FRANÇA, Rubens Limongi. O direito, a lei e a jurisprudência. São Paulo: Revista dos Tribunais, 1974.

FUX, Luiz; NERY JR., Nelson; WAMBIER, Teresa Arruda Alvim. Processo $e$ constituição: estudos em homenagem ao Professor José Carlos Barbosa Moreira. São Paulo: RT, 2006.

GARCIA, Maria. Sistemas constitucionais comparados: o sistema inglês ("common law") e norte-americano. Alguns aspectos do direito constitucional brasileiro. Cadernos de Direito Constitucional e Ciência Política n. o 09, ano 3, São Paulo: RT, out.-dez./1994.

GRECO FILHO, Vicente. Direito Processual Civil brasileiro. 14a ed., São Paulo: Saraiva, 2000 .

GRINOVER, Ada Pellegrini. O controle do raciocínio judicial pelos Tribunais Superiores brasileiros. Revista AJURIS, n. ${ }^{\circ}$ 50, ano XVII, nov./1990.

HALE, Matthew. The history of the common law of England. Chicago: Chicago University, 1971. 
HARRELL, Mary Ann; ANDERSON, Burnett. Equal Justice under Law: The Supreme Court in American Life. The Supreme Court Historical Society: Washington, D.C., 1982.

HAZARD, Geoffrey C.; TARUFFO, Michele. American civil procedure: an introduction. New Haven: Yale University, 1993.

HESPANHA, António Manuel. Panorama histórico da cultura jurídica europeia. Lisboa: Publicações Europa-Amércia, 1997.

HUGHES, Charles Evans. Six Lectures on the Supreme Court of the United States. Columbia University Lectures: George Blumenthal Foundation, 1927.

JACQUES, Paulino. Do relacionamento dos poderes políticos na Constituição do Império. Revista de Informação Legislativa n. ${ }^{\circ}$ 41, v. 11, Senado Federal, jan.-mar./1974.

JUNIOR, Jamacy José da Silva. O recurso antecipado e o recurso prematuro na visão dos Tribunais Superiores. Revista da Procuradoria-Geral do Banco Central n. ${ }^{\circ}$ 01, vol. 3, jun./2009.

JUNIOR, Nelson Nery; WAMBIER, Teresa Arruda Alvim (coords.). Aspectos polêmicos e atuais dos recursos cíveis e assuntos afins, v. 12. São Paulo: RT, 2011.

JÚNIOR, José Jesus Cazetta. Os assentos da Casa da Suplicação. Revista do Advogado, ano XXV, n. 84, dez./2005.

KATZ, Ellis. The complete American Constitution. Revista dos Tribunais n. ${ }^{\circ}$ 19, ano 5, abr.-jun./1997.

KORNHAUSER, Lewis A. An economic perspective on stare decisis. Kent Law Review n. 65, Chicago, 1989.

LACERDA, Galeno. Críticas ao prequestionamento. Revista dos Tribunais n. ${ }^{\circ}$ 758, São Paulo: RT, dez./1998.

LANDES, William M.; POSNER, Richard A. Legal precedent: a theoretical and empirical analysis. The Journal of Law and Economics, n. 19, 249, 1976. 
LEONEL, Ricardo de Barros. Recursos de sobreposição: novo procedimento e intervenção do amicus curiae. In: DIDIER JR., Fredie (coord). O terceiro no processo civil brasileiro e assuntos correlatos. Salvador: JusPodvum, 2010.

LOPES, José Reinaldo de Lima (org.). O Supremo Tribunal de Justiça do Império: 18281889. São Paulo: Saraiva, 2010.

MAC-CORMICK, Neil; SUMMERS, Robert (coord). Interpreting precedents: a comparative study. London: Dartmouth, 1997.

MACIEL, Adhemar Ferreira. Apanhado sobre a Constituição e a Suprema Corte dos Estados Unidos. Revista de Direito Público n. ${ }^{\circ} 73$, ano XVIII, jan.-mar./1985.

Restrição à admissibilidade de recursos na Suprema Corte dos Estados Unidos e no Supremo Tribunal Federal do Brasil. In: FABRÍCIO, Adroaldo Furtado. Meios de impugnação ao julgamento civil: estudos em homenagem a José Carlos Barbosa Moreira. $2^{\text {a }}$ ed. Rio de Janeiro: Forense, 2008.

MANCUSO, Rodolfo de Camargo. Recurso extraordinário e recurso especial. São Paulo: Revista dos Tribunais, 2008.

MARINONI, Luiz Guilherme; MITIDIERO, Daniel. O Projeto do CPC: críticas e propostas. São Paulo: RT, 2010.

MARKMAN, Stephen. Precedent: tension between continuity. In: The Law and the Perpetuation of Wrong Decisions, Texas Law Review of Law and Politics 8/283.

MAXIMILIANO, Carlos. Hermenêutica e aplicação do direito. $6^{\mathrm{a}}$ ed. Rio de Janeiro: Freitas Bastos, 1957.

MEDINA, José Miguel Garcia. O prequestionamento nos recursos extraordinário e especial. E outras questões relativas à sua admissibilidade e ao seu processamento. $4^{\mathrm{a}}$ ed. São Paulo: RT, 2001. 
Prequestionamento e repercussão geral: e outras questões relativas aos recursos especial e extraordinário, 5ª ed. São Paulo: RT, 2006.

MEDINA, José Miguel Garcia; WAMBIER, Teresa Arruda Alvim. Recursos e ações autônomas de impugnação. São Paulo: RT, 2008.

MENDES, Gilmar Ferreira. A Constituição e a estabilidade democrática, Folha de São Paulo, 19.10.2008.

MESQUITA, José Ignácio Botelho de. Recurso extraordinário e recurso especial: contrastes e confrontos. In: FABRÍCIO, Adroaldo Furtado. Meio de impugnação ao julgado civil: estudos em homenagem a José Carlos Barbosa Moreira. $2^{\mathrm{a}}$ ed. Rio de Janeiro: Forense, 2008.

MOREIRA ALVES, José Carlos. Poder Judiciário. A constituição brasileira (1988) Interpretações, vol. I. Rio de Janeiro: Editora Forense Universitária, 1983.

NETTO, José Manoel de Arruda Alvim. Notas sobre o Projeto de Novo Código de Processo Civil brasileiro. Congressso dos 170 anos do IAB: Instituto dos Advogados Brasileiros.

- A alta função jurisdicional do Superior

Tribunal de Justiça no âmbito do recurso especial e a relevância das questões. In: STJ 10 anos: obra comemorativa 1989-1999. Brasília: STJ, 1999.

MONTEIRO, André Luis. Duas providências do Projeto de Novo Código de Processo Civil para o fim da chamada jurisprudência defensiva: uma evolução rumo ao pleno acesso à Justiça. Revista de Processo n. ${ }^{\circ}$ 204, ano 37, São Paulo: RT, fevereiro/2012.

MACIEL, Adhemar Ferreira. Apanhado sobre a Constituição e a Suprema Corte dos Estados Unidos. Revista de Direito Público n. ${ }^{\circ} 73$, ano XVIII, jan.-mar./1985.

Restrição à admissibilidade de recursos na Suprema Corte dos Estados Unidos e no Supremo Tribunal Federal do Brasil. In: FABRÍCIO, Adroaldo Furtado. Meios de impugnação ao julgamento civil: estudos em homenagem a José Carlos Barbosa Moreira. $2^{\mathrm{a}}$ ed. Rio de Janeiro: Forense, 2008. 
MENEZES CORDEIRO, António. Da inconstitucionalidade da revogação dos assentos. In: MIRANDA, Jorge (org.). Perspectivas constitucionais nos 20 anos da Constituição de 1976. Coimbra: Ed. Coimbra, 1996.

MONNERAT, Fábio Victor da Fonte. O papel da jurisprudência e os incidentes de uniformização no Projeto do novo Código de Processo Civil. In: ROSSI, Fernando et al. (coords). O futuro do processo civil no Brasil: uma análise crítica ao Projeto do Novo CPC. Belo Horizonte: Fórum, 2011.

MONTORO, André Franco. Introdução à Ciência do Direito, 20ª ed. São Paulo: RT, 1991.

NEVES, A. Castanheira. O instituto dos assentos e a função jurídica dos Supremos Tribunais. Coimbra: Coimbra Editora, 1983.

Almedina, 1994.

O problema da constitucionalidade dos assentos. Coimbra:

NOBRE JÚNIOR, Edilson Pereira. O direito processual brasileiro e o efeito vinculante das decisões dos tribunais superiores. Revista de Processo n. 105, ano 27, jan.-mar./2002.

OLIVEIRA, Carlos Alberto Alvaro de. Do formalismo no processo civil. $4^{\mathrm{a}}$ ed. São Paulo: Saraiva, 2010.

PALADIN, Livio. Diritto costituzionale. 3 ed. Padova: Cedam, 1998.

PINHEIRO, Armando Castelar. Judicial System Performance and Economic Development. BNDES, out./1996.

PINTO, Valentina Mello Ferreira. A comparison between the writ of certiorari in the United States and the extraordinary appeal's general repercussion requisite in Brazil. Revista de Processo n. ${ }^{\circ} 187$, ano 35, set./2010.

RÁO, Vicente. O direito e a vida dos direitos, São Paulo: Max Limonad, 1952.

REALE, Miguel. Teoria do Direito e do Estado. $3^{\mathrm{a}}$ ed. São Paulo: Livraria Martins, 1940. 
Fontes e modelos do direito. São Paulo: Saraiva, 1994.

REZEK, Francisco. O direito que atormenta. Folha de S. Paulo, 15.11.1998.

RIBEIRO, Paulo de Tarso Ramos. Direito e Processo: Razão Burocrática e Acesso à Justiça. São Paulo: Max Limonad, 2002.

ROSAS, Roberto. Direito sumular. 11 ${ }^{\text {a }}$ ed. São Paulo: Malheiros, 2002.

SANTOS, Paula Ferraresi. Prequestionamento e sua aplicação nos Tribunais Superiores: uma análise crítica. Revista de Processo n. ${ }^{\circ}$ 216, ano 38, fev./2013.

SCHAUER, Frederick. Precedent. Stanford Law Review n. 39, fev./1987.

SILVA, Ovídio Araújo Baptista da. Questão de fato em recurso extraordinário. In: FABRÍCIO, Adroaldo Furtado (coord.). Meios de impugnação ao julgado civil: estudos em homenagem a José Carlos Barbosa Moreira. 2a ed. Rio de Janeiro: Forense, 2008.

SILVA, Nunes Espinosa Gomes da. História do direito português: fontes de Direito, vol I. Lisboa: Fundação C. Gulbenkian, 1985.

SILVA, Paulo Eduardo Alves da. Gerenciamento de processos e cultura de litigância: a experiência do case management inglês. In: SALLES, Carlos Alberto de (coord.). As grandes transformações do processo civil brasileiro: homenagem ao Professor Kazuo Watanabe. São Paulo: Quartier Latin, 2009.

SIMON, Helmut. La jurisdicción constitucional. In: BENDA, Ernesto et al. Manual de derecho constitucional. Madrid: Marcial Pons, 1996.

SLAPPER, Gary. KELLY, David. O sistema jurídico inglês. Tradução de Marcílio Moreira de Castro. $1^{\text {a }}$ ed. brasileira. Rio de Janeiro: Gen, Forense, 2011.

SOARES, Guido Fernando Silva. Common Law: Introdução ao direito dos EUA. $2^{\mathrm{a}}$ ed. São Paulo: RT, 2000. 
SORIANO, Leonor Moral. El precedente judicial. Madrid: Marcial Pons, 2002.

STERN, Robert L. et. al. Supreme Court practice: for practice in the Supreme Court of the United States. $8^{\text {th }}$ ed. Washington: Bna Books, 1986.

STRECK, Lenio Luiz; BARRETTO, Vicente de Paulo; OLIVEIRA, Rafael Tomaz de. Ulisses e o Canto das Sereias: sobre ativismos judicias e os perigos da instauração de um terceiro turno da Constituinte. Revista Magister de Direito Civil e Processual Civil, ano VI, n. ${ }^{\text {3 } 31, ~ j u l .-a g o . / 2009 . ~}$

TARUFFO, Michele. Precedente $i$ giurisprudenza. Napoli: Editoriale Scientifica SRL, 2007.

Dimensiones del precedente judicial. Paginas sobre justicia civil, $\mathrm{n}$.

33. Madrid: Marcial Pons, 2009.

TEDESCO, Paulo Camargo. Jurisprudência defensiva de segunda geração. Revista de Processo, ano 35, n. 182, abril/2010.

THEODORO JÚNIOR, Humberto. Recurso especial - prequestionamento. Revista Síntese

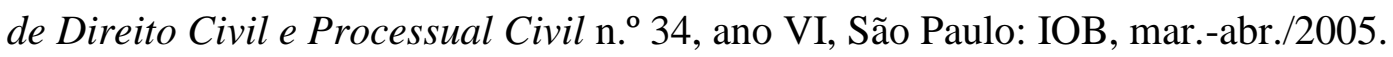

Litigiosidade em massa e repercussão geral no recurso extraordinário. Revista de Processo n. ${ }^{0}$ 177, São Paulo: RT, nov./2009.

TOCQUEVILLE, Alexis de. O Antigo Regime e a Revolução, trad. portuguesa de Laurinda Bom. Lisboa: Fragmentos, 1989.

TUCCI, José Rogério Cruz e; AZEVEDO, Luiz Carlos de. Lições de história do processo civil lusitano. São Paulo: RT, 2009.

TUCCI, José Rogério Cruz e. Garantia da prestação jurisdicional sem dilações indevidas como corolário do devido processo legal. Revista de Processo n. ${ }^{\circ}$ 66, São Paulo: RT, abr.jun./1992. 
. Precedente judicial como fonte do direito. São Paulo: RT,

2004.

Parâmetros de eficácia e critérios de interpretação do

precedente judicial. In: WAMBIER, Teresa Arruda Alvim (coord.). Direito jurisprudencial. São Paulo: Revista dos Tribunais, 2012.

VIGLIAR, José Marcelo Menezes. Uniformização de jurisprudência. São Paulo: Atlas, 2003.

VON MEHREN, Arthur Taylor; GODLEY, James Russell. The Civil Law System: an Introduction to the Comparative Study of Law, $2^{\text {nd }}$ ed. Boston: Little, Brown, 1977.

WALD, Arnoldo. Eficiência Judiciária e Segurança Jurídica: A racionalização da legislação brasileira e reforma do Poder Judiciário. In: MACHADO, Fábio Cardoso \& MACHADO, Rafael Bicca (coords.). A Reforma do Poder Judiciário. São Paulo: Quartier Latin, 2006.

O Novo Supremo Tribunal Federal. In: SILVA, Christine Oliveira Peter da \& CARNEIRO, Gustavo Ferraz Sales (coords.). Controle de Constitucionalidade $e$ Direitos Fundamentais - estudos em homenagem ao Professor Gilmar Mendes. RJ: Lumen Juris, 2010.

WAMBIER, Luiz Rodrigues. Uma proposta em torno do conceito de jurisprudência dominante. Revista de Processo n. 100, v. 25, São Paulo: RT, 2000, out.-dez./2000.

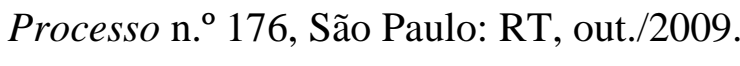

Recurso especial e ações de família. Revista de

WAMBIER, Teresa Arruda Alvim. Recurso especial, recurso extraordinário e ação rescisória. $2^{\mathrm{a}}$ ed. São Paulo: Revista dos Tribunais, 2008.

A uniformidade e a estabilidade da jurisprudência e

o Estado de direito: civil law e common law. Ideias e opiniões, v. 7. Curitiba, out./2009. 
dos Tribunais, 2012.

WITTMANN, Ralf-Thomas. Il contenzioso 'di massa' in Germania. In: ALESSANDRO, Giogetti; VALLEFUOCO, Valerio. Il contenzioso di massa in Italia, in Europa e nel mondo. Giuffrè: Milão, 2008.

\section{II) Artigos eletrônicos}

BARBOSA, Rui. Oração aos moços, edição popular anotada por Adriano da Gama Kury. Rio de Janeiro: Fundação Casa de Rui Barbosa, 1997. Disponível [online] em http://www.casaruibarbosa.gov.br/dados/DOC/artigos/rui_barbosa/FCRB_RuiBarbosa_Or acao_aos_mocos.pdf.

Câmara dos Deputados do Brasil. Proposta de Emenda Constitucional n. ${ }^{o}$ 209/2012. Disponível [online] em: http://www.camara.gov.br/proposicoesWeb/prop_mostrarintegra?codteor=1277724\&filena $\underline{\text { me}=\text { Tramitacao-PEC+209/2012. }}$.

Câmara dos Deputados do Brasil. Comissão temporarária para votar o novo CPC. Disponível [online] em http://www2.camara.leg.br/atividadelegislativa/comissoes/comissoes temporarias/especiais/54a-legislatura/8046-10-codigo-deprocesso civil/proposicao/pareceres-e-relatorios.

Câmara dos Deputados do Brasil. Juristas tentam superar divergências entre versões do novo CPC. 11.06.2014. Disponível [online] em http://www2.camara.leg.br/camaranoticias/noticias/DIREITO-E-JUSTICA/470264JURISTAS-TENTAM-SUPERAR-DIVERGENCIAS-ENTRE-VERSOES-DO-NOVOCPC.html.

Consultor Jurídico. Estudo mostra que STF é Corte recursal. 04.05.2011. Disponível [online] em http://www.conjur.com.br/2011-mai-04/estudo-mostra-stf-corte-recursaluniao-maior-usuario.

Cour de Cassation. The role of the Court of Cassation. Disponível [online] em https://www.courdecassation.fr/IMG/File/About\%20the\%20court_mars09.pdf. 
Conseil Constitutionnel française. Liste des membres du Conseil constitutionnel. Disponível [online] em http://www.conseil-constitutionnel.fr/conseilconstitutionnel/francais/le-conseil-constitutionnel/les-membres-du-conseil/liste-desmembres/liste-des-membres-du-conseil-constitutionnel-*.319.html.

Corte di Cassazione. Le funzione della Corte. Disponível [online] em http://www.cortedicassazione.it/corte-dicassazione/it/funzioni_della_corte.page;jsessionid=00E97829E80603D9F94717358AC6A C07.jvm1.

JOBIM, Nelson. Discurso de posse à Presidência do STF em 03/06/2004. Disponível em http://www.stf.jus.br/arquivo/cms/publicacaoPublicacaoInstitucionalPossePresidencial/ane xo/Plaqueta_de_Posse_Ministro_Nelson_Jobim_na_Presidencia.pdf.

JUNIOR, Otavio Luiz Rodrigues. Crise do europeismo leva tribunais britânicos de volta ao common law. Consultor Jurídico, 03.09.2014. Disponível em http://www.conjur.com.br/2014-set-03/direito-comparado-crise-europeismo-leva-tribunaisvolta-common-law.

MESSITTE, Peter J. The writ of certiorari: deciding which cases to review. USINFO: Washington, 29.07.2008, disponível em: http://iipdigital.usembassy.gov/st/english/publication/2008/08/20080814211720xjyrrep0.5 789301.html\#axzz3JvhILTj8.

Portal Migalhas, STF se aproxima da terceira década de existência sob severa crise de funcionalidade, diz Barroso. 26.08.2014. Disponível [online] em http://www.migalhas.com.br/Quentes/17,MI206523,71043-

$\underline{\mathrm{STF}+\text { se+aproxima+da+terceira+decada+de+existencia+sob+severa+crise+de. }}$

POSNER, Richard. An economic approach to the law of evidence. John M. Olin Law \& Economics Working Paper n. ${ }^{\circ}$ 66. University of Chicago. Disponível [online] em http://www.law.uchicago.edu/Publications/Working/index.html.

Portal Migalhas. Novo CPC vai à sanção presidencial. 17.12.2014. Disponível [online] em http://www.migalhas.com.br/Quentes/17,MI213017,11049-

Novo+CPC+vai+a+sancao+presidencial. 
Projeto de novo Código de Processo Civil: Versão Câmara dos Deputados - Redação final aprovada em 26.03.2014. Bahia: Editora JusPodivm, 2014. Disponível no site do Instituto Brasileiro de Direito Processual $\quad$ (IBDP), http://www.direitoprocessual.org.br/download.php?f=5e513900c9435148931ae6646f9455f a.

Senado Federal do Brasil. Novo Código de Processo Civil: comissão vota sugestões dos deputados no dia 4. Disponível [online] em http://www12.senado.gov.br/noticias/materias/2014/11/27/novo-codigo-de-processo-civilcomissao-vota-sugestoes-dos-deputados-no-dia-4.

Senado Federal do Brasil. Exposição de Motivos do Anteprojeto do Novo Código de Processo Civil. Disponível em: http://www.senado.gov.br/senado/novocpc/pdf/anteprojeto.pdf.

Superior Tribunal de Justiça. Discurso de Posse do Ministro Humberto Gomes de Barros. 07.04.2008. Disponível [online] em http://ftp.stj.jus.br/portal_stj/publicacao/engine.wsp?tmp.area=551\&tmp.texto=87057.

Supremo Tribunal Federal. Números da Repercussão Geral. Disponível [online] em http://www.stf.jus.br/portal/cms/verTexto.asp?servico=jurisprudenciaRepercussaoGeral\&p agina=numeroRepercussao.

Supremo Tribunal Federal. Discurso de posse do Ministro Nelson Jobim à Presidência do STF. 03.06.2004. Disponível [online] em http://www.stf.jus.br/arquivo/cms/publicacaoPublicacaoInstitucionalPossePresidencial/ane $\underline{\text { xo/Plaqueta_de_Posse_Ministro_Nelson_Jobim_na_Presidencia.pdf. }}$

Supremo Tribunal Federal. "PEC dos Recursos" é apresentada pelo presidente do STF e estará no III Pacto Republicano. 21.03.2011. Disponível [online] em http://www.stf.jus.br/portal/cms/verNoticiaDetalhe.asp?idConteudo=174751.

Supremo Tribunal Federal. Definição de repercussão geral. Disponível [online] em http://www.stf.jus.br/portal/glossario/verVerbete.asp?letra=R\&id=451>. 
The Legislative Works of Alfonso $X$, el Sabio, disponível em http://faculty.washington.edu/petersen/alfonso/lawtrans.htm.

WOOLF, Access to Justice Final Report - Final Report to the Lord Chancellor on the civil justice system in England and Wales, 1996, disponível em http://www.dca.gov.uk/civil/final/index.htm. 